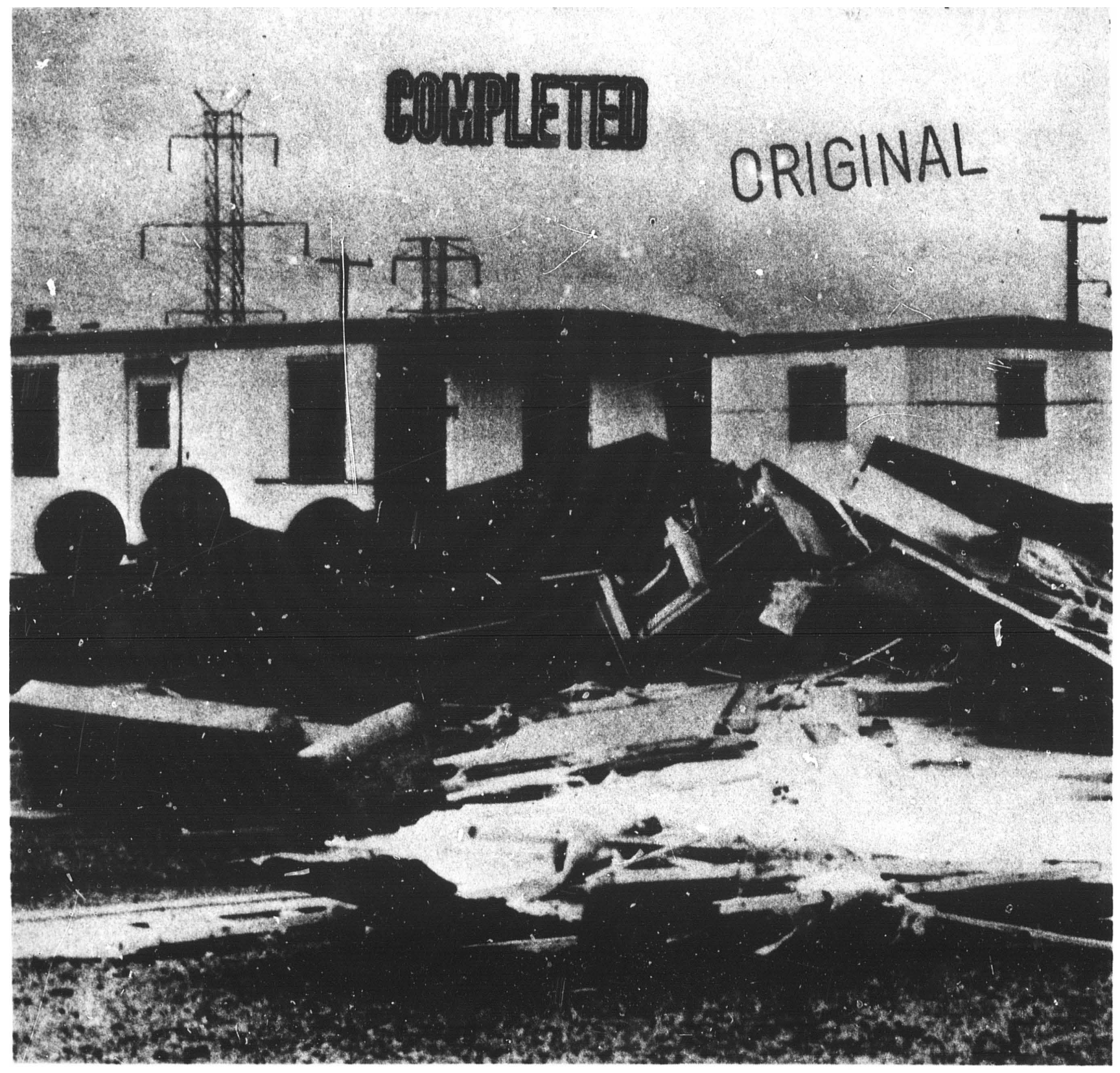

NBS BUILDING SCIENCE SERIES 142

\title{
Load-Displacement Characteristics of Shallow Soil Anchors
}

U.S. DEPARTMENT OF COMMERCE • NATIONAL BUREAU OF STANDARDS 


\section{NATIONAL BUREAU OF STANDARDS}

The National Bureau of Stan'lard:' was established by an act of Congress on March 3, 1901. The Bureau's overall goal is to strengthen and advance the Nation's science and technology and facilitate their effective application for public benefit. To this end, the Bureau conducts research and provides: (1) a basis for the Nation's physical measurement svstem, (2) scientific and technological services for industry and government, (3) a technical basis for equity in trade, and (4) technical services to promote public salety. The Bureau's teclinical work is performed by the National Measurement Laboratory, the National Engineering Laboratory, and the Institute for Computer Sciences and Technology.

THE NATIONAL MEASUREMENT LABORATORY provides the national system of physical and chemical and materials measurement; coordinates the system with measurement systems of other nations and furnishes essential services leading to accurate and uniform physical and chemical measurement throughout the Nation's scientific community, industry, and commerce; conducts materials research leading to improved methods of measurement, standards, and data on the properties of materials needed by industry, commerce, educational institutions, and Government; provides advisory and research services to other Government agencies; develops, produces, and distributes Standard Reference Materials; and provides calibration services. The Laboratory consists of the fo!lowing centers:

$$
\begin{aligned}
& \text { Absolute Physical Quantities }{ }^{2} \text { - Radiation Research - Chemical Physics - } \\
& \text { Analytical Chemistry - Materials Science }
\end{aligned}
$$

THE NATIONAL ENGINEERING LABORATORY provides technology and technical services to the public and private sectors to address national needs and to solve national problems; conducts research in engineering and applied science in support of these efforts; builds and maintains competence in the necessary disciplines required to carry out this research and technical service; develops engineering data and measurement capabılities; provides engineering measurement traceability services; develops test methods and proposes engineering standards and code changes; develops and proposes new engineering practices; and deveiops and improves mechanisms to transfer results of its research to the ultimate user. The Laboratory consists of the following centers:

Applied Mathematics - Electronics and Electrical Engineering ${ }^{2}$ - Manufacturing Engineering - Building Technology' -- Fire Research - Chemical Engineering ${ }^{2}$

THE INSTITUTE FOR COMPUTER SCIENCES AND TECHNOLOGY conducts research and provides scientific and technical services to aid Federal agencies in the selection, acquisition, application, and use of computer technology to improve effectiveness and economy in Government operations in accordance with Public Law 89-306 (40 U.S.C. 759), relevant Executive Orders, and other directives; carries out this mission by managing the Federal Information Processing Standards Program, developing Federal ADP standards guidelines, and managing Federal participation in ADP voluntary standardization activities; provides scientific and technological advisory services and assistance to Federal agencies; and provides the technical foundation for computer-related policies of the Federal Government. The Institute consists of the following centers:

Programming Science and Technology - Computer Systems Engineering.

'Headquarters and Laboratories at Gaithersburg, MD, unless otherwise noted; mailing address Washington, DC 20234.

'Some divisions within the center are located at Boulder, CO 80303. 


\section{Load-Displacement Characteristics of Shallow Soil Anchors}

Felix Y. Yokel

Riley M. Chung

Frank A. Rankin

Charles W. C. Yancey

Center for Building Technology

National Engineering Laboratory

National Bureau of Standards

Washington, DC 20234

Prepared for the

Office of Policy Development and Research

U.S. Department of Housing and Urtan Development

Washington, DC 20410

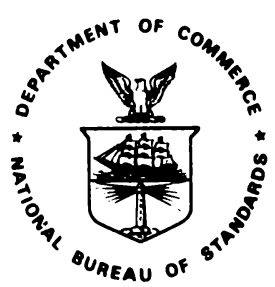

U.S. DEPARTMENT OF COMMERCE, Malcolm Baldrige, Secretary

NATIONAL BUREAU OF STANDARDS, Ernest Ambler, Director

Issued May 1982 


\section{Library of Congress Catalog Card Number: 82-600509}

National Bureau of Standards Building Science Series 142

Nat. Bur. Stand. (U.S.), Bldg. Sci. Ser. 142, 163 pages (May 1982)

CODEN: BSSNBV

\section{U.S. GOVERNMENT PRINTING OFFICE \\ WASHINGTON: 1981}

For sale by the Superintendent of Documents, U.S. Government Printing Office, Washington, D.C. 20402

Price $\$ 6.50$

(Add 25 percent for other than U.S. mailing) 


\section{ABSTRACT}

Tests on shallow soll anchors, commonly used by the mobile home industry, including 6-in single helix and 4-in double hellx anchors as well as three types of swivel anchors, were conducted on three sites: a silty site, a sandy site, and a clay site. Test variables included direction of anchor installation; direction of loading; anchor depth; size of anchor plate; and cyclic load effects. The effect of these test variables on load-displacement characteristics, measured at the anchor head, is investigated. It is concluded that on most sites the anchor types tested, when installed in accordance with present industry practice for mobile home tledown systems, did not deliver the anchor performance required in present standards. It 1s recommended that minimum load capacity requirements for anchors be waived; that all anchors be preioaded to 1.25 times the design load; and that one anchor per moblle home, or three anchors per site if soll conditions are uniform, be preloaded to $1 . j$ times the design load.

Keywords: anchors; cyclic loading; fleld testing; flood forces; foundations; load capacity, mobile homes; soll anchors; soll mechanics; stiffness; wind forces.

COVER: Mobile home damaged by wind. Anchored mobile homes in the vicinity suffered only minor damage. 


\section{PRE FACE}

This report is part of a study which was sponsored by the office of Policy Development and Research of the U.S. Department of Housing and Urban Development. The overall objectives of this study were: to determine wind and flood forces acting on mobile homes; to study the performance characteristics of soil anchors; and to develop performance criteria for mobile home foundations with particular emphasis on the t-iedown system. In previous stages of this work, measurements were made of the wind forces acting on mobile homes, the state-ofthe-art in anchoring technology was studied, and the forces acting on tiedown systems were determined. The work was published in references [13], [12], and [20;, respectively. This report deals with the results of experimental and analytical studies of the load capacity of soil anchors used to tie down mobile homes and with methods to insure adequate performance of soil anchors. Initial resul.ts of this work were presented in reference [19], pp. 3-20.

This stidy was performed by the Geotechnical Engineering Group of the Center for Bullding Technology.

1 Numbers in brackets refer to the literature references in section 7 . 


\section{EXECUTIVE SUMMARY}

Two hundred and thirty-two anchor tests were conducted on three sites: a silty site; a sandy site; and a clay site. Anchors tested included 6-in single helix, 4 -in double helix, and 3-in single helix anchors, and 6-in triangular, $101 / 4$ length $\times 1$ 3/4-in o.d. pipe, and $61 / 2$ length $\times 1$ 1/4-in o.d, pipe swivel

("fluke") anchors. Loading conditions included coaxial and noncoaxial (inclined) pull on vertical and inclined anchors installed to their full depth, and coaxial puli ori anchors installed at various depths ranging from 1 tt to $4 \mathrm{ft}$. Modes of loading ircluded monotonic tests, monotonic tests with several intermediate cycles of unloading and reloading, and cyclic tests. The tests were carriad to complete withdrawal and graphs of load vs. anchor-head displacement were electronically recorded. Several anchor tests were carried out under submerged conditions. The tests were correlated with determinations of soil conditions by in-situ and laboratury tests. In-situ tests included soil test probe readings, standard penetration tests, and measurement of the anchor installation torque. It was concluded that:

1. The anchors tested did not deliver the anchor performance required by ANSI Standard A119.3 [2].

2. The virgin load-displacement characteristics of anchors are a unique function of Installation depth, loading, and soll conditions and are not substantially altered by intermediate unloading and reloading cycles unless a great number of cycles of load close to the load capacity are applied.

3. The initial resistance to displacement of preloaded anchors in all loading modes is much higher than that in the first loading cycle and far exceeds the performance required by ANSI Standard Al19.3.

4. Coaxially loaded inclined anchors have smaller load capacities than coaxially loaded vertical anchors but their initial resistance to displacement is similar to that of coaxially loaded vertical anchors.

5. Vertical anchors subjected to inclined loads have higher load capacities than coaxially loaded vertical anchors, but their initial resistance to displacement (if they are not preloaded) is much less than that of coaxially loaded vertical anchors.

6. Swivel ("fluke") anchors can deliver satisfactory performance if properly seated and adequately preloaded.

7. Helix anchors lose their protective paint coat during installation and thus have no corrosion protection.

8. Helix anchors experience bending of the helix in all loading modes and bending of the shaft in noncoaxial loading. 
9. Helix anchor hardware tended to have adequate load capacily but was vulnerable in the weld between the shaft and the helix, particularly when subjected to noncoaxial cyclic load.

It is recommended to:

1. Eliminate the minimum load capacity requirements for anchors in present standards and stipulate instead required anchor resistance per mohile home, so that the number of anchors used can be determined in accordance with site conditions.

2. Require that every anchor be preloaded in the direction of the anticipated service load to 1.25 times the working load during installation, and that one anchor per mobile home, or three anchors per site where soli conditions are uniform, be preloaded to 1.5 times the required working load; and that the required working load be the load calculated for the design wind pressure without the increase for foundations presently required in the Federal standard [9].

3. Require that anchors be adequately protected against corrosion by galvanizing or other means; that the corrosion protection be effective for the service iffe of the mobile home, and remain effective if anchor deformation anticipated under the preload or the service load occurs.

It is noted that if anchors are to be included as part of a permanent mobile home foundation, they should be durable enough to retain their structural integrity throughout the service life of the mobile home; they should be preloaded; and consideration should be given to potential effects of frost heave. 
ABSTRACT $\ldots \ldots \ldots \ldots \ldots \ldots \ldots \ldots \ldots \ldots \ldots \ldots \ldots \ldots \ldots \ldots \ldots \ldots \ldots \ldots \ldots \ldots \ldots \ldots \ldots \ldots \ldots \ldots$ 111

PREFACE $\ldots \ldots \ldots \ldots \ldots \ldots \ldots \ldots \ldots \ldots \ldots \ldots \ldots \ldots \ldots \ldots \ldots \ldots \ldots \ldots \ldots \ldots \ldots \ldots \ldots \ldots \ldots$ EXECUTIVE SUMMARY LIST OF FIGURES

LIST OF TABLES

LIST OF SYMBOLS

SI CONVERSION

1. INTRODUCTION $\ldots \ldots \ldots \ldots \ldots \ldots \ldots \ldots \ldots \ldots \ldots \ldots \ldots \ldots \ldots \ldots \ldots \ldots \ldots \ldots \ldots \ldots \ldots \ldots \ldots$

2. SCOPE $\ldots \ldots \ldots \ldots \ldots \ldots \ldots \ldots \ldots \ldots \ldots \ldots \ldots \ldots \ldots \ldots \ldots \ldots \ldots \ldots \ldots \ldots \ldots \ldots \ldots \ldots \ldots \ldots \ldots$

3. TEST SETUP AND PROGRAM $\ldots \ldots \ldots \ldots \ldots \ldots \ldots \ldots \ldots \ldots \ldots \ldots \ldots \ldots \ldots \ldots \ldots \ldots$

3.1 Description of Test Sites $\ldots \ldots \ldots \ldots \ldots \ldots \ldots \ldots \ldots \ldots \ldots \ldots \ldots \ldots$

3.1 .1 General .....................................

3.1 .2 Test Site A, Silty Solls ........................

3.1.3 Test Site B, Sandy Solls .........................

3.1.4 Test Site C, Clayey Solls ........................

3.2 Test Specimens and Frocedures .........................

3.2 .1 Anchors Tested ..............................

3.2.2 Test Apparatus ..................................

3.2.3 Testing Procedure .............................

3.3 Test Program .......................................

3.3.1 General ......................................

3.3.2 Test Variables ................................

3.3.3 Summary of Test Program ........................

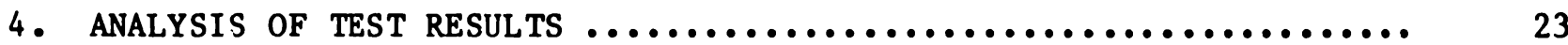

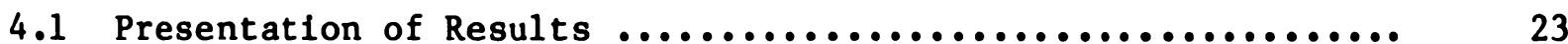

4.2 Effect of Loading Rate .............................

4.3 Static Load-Displacement Characteristics of 6-in Single

Hel1x Anchors ...................................... 28

4.3.1 Monotonic Tests .................................. 28

4.3.2 Unloading and Reloading Cycles ..................... 28

4.3.3 Anchors Installed at an Angle and Pulled Coaxially .... 31

4.3.4 Anchors Installed Vertically and Pulled at an Angle ... 31

4.3.5 Effects of Loading Configuration ...................

4.3.6 Effects of Inclination and Depth on the Load Capacity of Coaxially Loaded Anchors .......................

4.3.7 Comparison of Coaxially Loaded Inclined Anchors and Vertical Anchors Subjected to Inclined Loads ..........

4.4 Comparison between Different Anchors Types ................

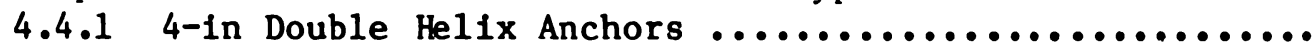
4.4.2 3-in Single Helix Anchors ....................... 4.4.3 Self-seating Swivel Anchors .....................

4.5 Effect of Soil Characteristics .......................... 4.5.1 Coaxially Loaded Vertical Anchors 
4.5.2 Vertically Installed Anchors Pulled at an Angle ....... 4.5.3 Effect of Depth and Anchor Inclination of Coaxial Load Capacity ..............................

4.5.4 Reloading Modul1 .............................

4.6 Prediction of Anchor Load-Capacity ...................... 4.6 .1 General .................................... 4.6.2 Correlation of Anchor Capacity with In Situ Tests ..... 4.6.3 Theoret1cal Determination of Anchor-Load Capac1ty ..... 4.6.4 Determination of Load Capacity on the Basis of Pullout Tests in Similar Conditions .................... 4.6.5 Effect of Submerged Conditions .....................

4.7 Cyclic Tests ....................................... 4.7.1 Cyclic Tests on Silty Site ....................... 4.7.2 Cyclic Tests on the Sandy Site ..................... 4.7.3 Cyclic Tests on the Clay Site ..................... 4.8 Comparison of Anchor Performance with Present Standard Requirements ..................................... 4.9 Performance of Anchor Hardware $\ldots \ldots \ldots \ldots \ldots \ldots \ldots \ldots \ldots \ldots \ldots \ldots \ldots \ldots$

5. SUMMARY OF CONCLUSIONS ................................. 93

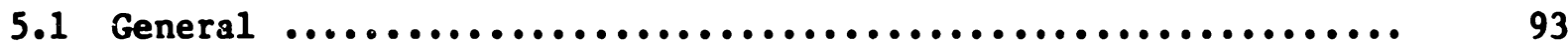

5.2 Virgin I.oad-Displacement Curves .......................... 94

5.3 Reloading Characteristics ............................... 94

5.4 Effects of Loading Configuration ......................... 94

5.5 Effects of Soll Type ................................... 95

5.6 Prediction of Anchor-Load Capacity by In-Situ Tests ......... 95

5.7 Theoretical Prediction of Anchor-Load Capacity .............. 95

5.8 Prediction of Anchor-Load Capacities on the Basis of Tests on

Similar Sites ...................................

5.9 Anchors Subjected to Cyclic Load .........................

5.10 Comparison of Anchor Performance with Present Standard

Requirements ......................................

5.11 Performance of Anchor Hardware ......................... 96

5.12 Use of Soll Anchors in Permanent Mobile Home Foundations ..... 97

6. RECOMENDATIONS ........................................... 99

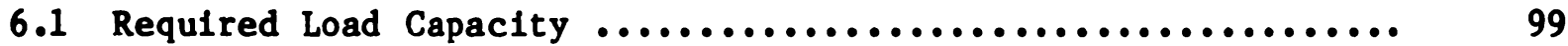

6.2 Installation Requirements .............................. 100

6.3 Corrosion Protection .................................. 103

6.4 Anchor Hardware Capac1ty ............................. 103

7. REFERENCES ............................................ 105

8. ACKNOWLEDGMENTS ....................................... 107 
TABLE OF CONTENTS (Continued)

APPENDIX A TEST SITES

A.1 Introduction .............................................. 109

A.2 Soll Exploration Reports $. . \ldots \ldots \ldots \ldots \ldots \ldots \ldots \ldots \ldots \ldots \ldots \ldots \ldots \ldots \ldots, 114$

APPENDIX B TEST RESULTS

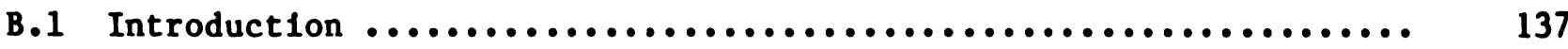

B.2 Symbols Used in the Tables $. . \ldots \ldots \ldots \ldots \ldots \ldots \ldots \ldots \ldots \ldots \ldots \ldots \ldots . . . \ldots \ldots$ 


\section{LIST OF FIGURES}

Page

Figure 1.1 Typical mobile home tiedown systems $\ldots \ldots \ldots \ldots \ldots \ldots \ldots \ldots \ldots \ldots . \ldots$

Figure 1.2 Single and double helix anchors $\ldots \ldots \ldots \ldots \ldots \ldots \ldots \ldots \ldots \ldots \ldots$

Figure 3.1 Self seating swivel anchors (triangular and pipe) used in the test program ................................

Figure 3.2

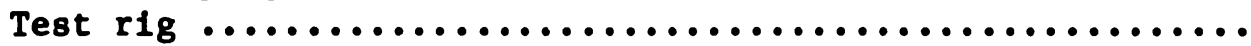

Fjgure 4.1 Plot of test C-7, vertical 6-in single helix anchor, vertical pull ..................................

Figure 4.2

Effect of loading rate on load-displacement

characteristics ...............................

27

Figure 4.3

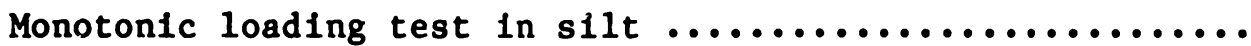

29

Pullout test with unloading and reloading cycles in sand ..

Figure 4.5

Coaxial pullout test on inclined 6-in single helix

anchor in sand .................................

F1gure 4.6

Inclined pullout test on a vertically installed 6-in

single helix anchor in sand .........................

Figure 4.7 Anchor deformation in inclined test on vertically installed 4-1n double hel1x anchu= ..........................

F1gure 4.8

Effect of loading configuration on load-displacement

characteristics of anchors .........................

Figure 4.9

Effects of load Inclination on the load-displacement characteristics of vertically installed anchors ..........

Figure 4.10 Load-displacement characteristics of inclined anchors subjected to non-coaxial loads on the silty site ..........

Figure 4.11 Load-deflection curves for coaxially loaded 6-in single helix anchors installed at various angles ..............

Figure 4.12 Effects of embedment depth on the load capacity of vertically installed 6 -in single helix anchors subjected to coaxial load ..................................

Figure 4.13 Comparison between inclined and vertical coaxially pulled 6-in single helix anchors ........................... 42

Figure 4.14 Comparison between the load-displacement characteristics of 6-in single helix and 4-in double helix anchors ........

Figure 4.15 Comparison of load-displacement characteristics of vertically installed 4-in double helix anchors pulled at different angles ...............................

Figure 4.16 Comparison of load-displacement characteristics of coaxially loaded 4-in double helix anchors installed at different angles ................................. Load-displacement characteristics of self seating swivel anchors in silty so11 .......................... 


\section{LIST OF FIGURES (Continued)}

Page

Figure 4.19 Load-displacement characteristics of coaxially loaded 6-in single helix anchors on the sand, silt and clay sites ..... 5 j

Figure 4.20 Vertically installed 6-in single helix anchors pulled at a $40^{\circ}$ angle on the sand, silt, and clay sites .......... 56

Figure 4.21 Correlation between Soil Test Probe readings and coaxial load capacity of vertically installed 6-in single helix

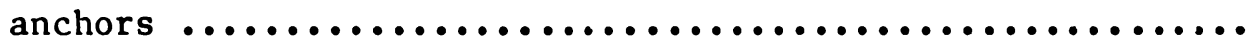

Figure 4.22 Correlation between Soil Test Probe readings ard coaxial load capacity of vertically installed 4-in double helix

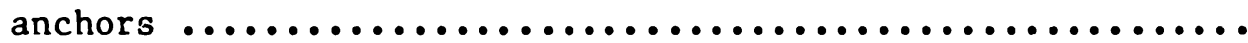

Figure 4.23 Correlation between Soll Test Probe readings averaged over a $2.5 \mathrm{ft}$ depth and the load capacity of coaxially loaded

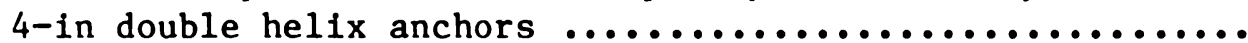

Figure $4.243 \mathrm{ft}$ deep 6-in single helix anchor after pullout on the

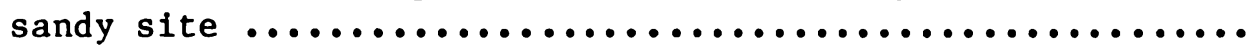

Figure 4.25 Relationship between STP measurements and the shear

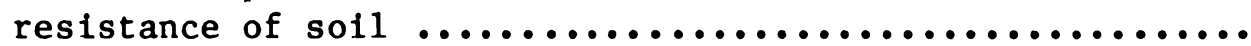

Figure 4.26 Relationship between installation torque and pullout strength for vertical, coaxially loaded 6-in single helix

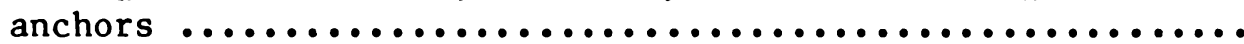

Figure 4.27 Relationship between installation torque and pullout strength for vertical, coaxially loaded 4-in double helix

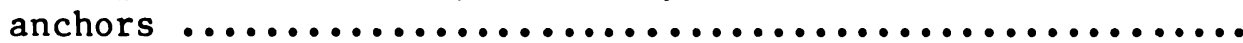

Figure 4.28 Correlation between SPT blowcount and STP torque readings

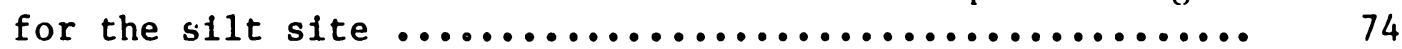

Figure 4.29 Effect of anchor plate size on $q$ in the silt and clay

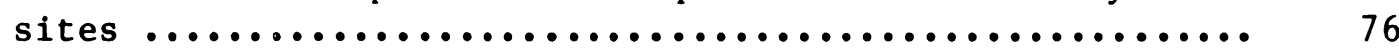

Figure 4.30 Cyclic load tests in silty soils ..................... Figure 4.31 Cyclic load tests in sandy soils ......................

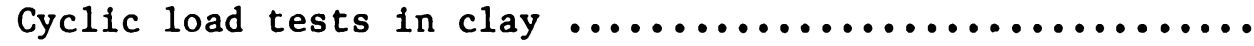

Figure 4.32

Figure 4.33 Comparison of the preloading curves of tests $\mathrm{C} 26$ and C27 ..

Figure 4.34 Results of the cyclic loding test of specimen C33 on the clay site .................................

Figure 4.35 Typical anchor hardware failures $\ldots \ldots \ldots \ldots \ldots \ldots \ldots \ldots \ldots \ldots \ldots$

Figure 6.1 Illustration of the recommended preloading requirement and the resulting anchor performance ...................... 101

Figure 6.2 Suggested preloading procedures for diagonally loaded anchors $\ldots \ldots \ldots \ldots \ldots \ldots \ldots \ldots \ldots \ldots \ldots \ldots \ldots \ldots \ldots \ldots \ldots \ldots \ldots \ldots \ldots \ldots \ldots$

Figure A.1 Figure A.2 Figure A.3 Figure A.4
Anchor tests and boring locations cn Site A .............. Anchor test and boring locations on Site B.1 ............ Anchor test and test pit locations on Site B.2 ........... Anchor test and boring locations on Site $C$
110

111

112

113 


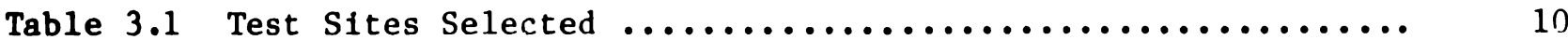

Table 3.2 Summary of Test Program .............................

Table 4.1 Reloading Moduli $\left(\mathrm{R}_{85}\right)$ for the Tests Shown

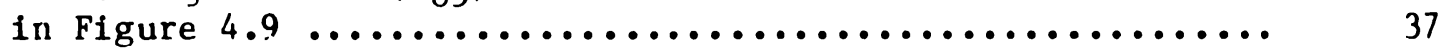

Table 4.2 Comparison of the Strength of Coaxially Loaded Anchors Installed at Various Depths ........................ 43

Table 4.3 Effect of Anchor Inclination on the Load Capacity of Coaxially Loaded 4-in Double Helix Anchors in Silty Soils .. 49

Table 4.4 Comparison of Load Capacities of 3-in and 6-in Single Hel1x Anchors ...................................

Table 4.5 Load Capacity of Self-Seating Swivel Anchors Tosted in

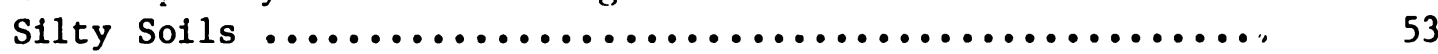

Table 4.6 Re-loading Moduli of Swivel Anchors Tested in Silty Soils .. Table 4.7 Comparison of the Effects of Load Inclination on the Load Capacities of Vertically Installed Anchors on

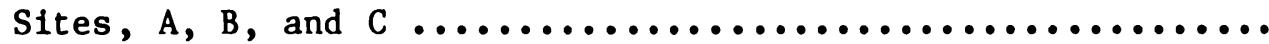

Table 4.8 Effect of Anchor Depth and Inclination on the Load Capacity of Coaxially Loaded Single Helix Anchors ................

Table 4.9 Effects of Anchor Inclination on the Load Capacity of 4-in

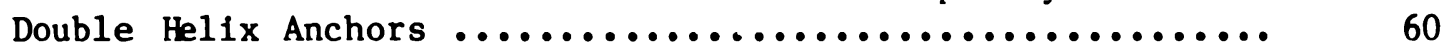

Table 4.10 Comparison of Reloading Moduli Measured on the Three

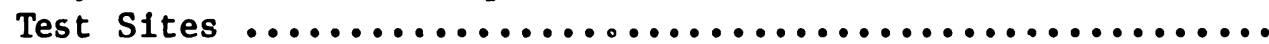

Table 4.11 Uplift Capactiy Factors ror Full-Depth Anchors on the Sandy Site ......................................... 79

Table 4.12 Uplift Capacity Factors for 6-in Single Helix Anchors Installed to Less than Their Full Depth on the Sandy Site ..

Table 4.13 Range, Mean, and Coefficients of Variation of the Load Capacities of the Full Depth Anchors ...................

Table 4.14 Comparison Between Regular and Submerged Anchor Tests on the Silty Site .................................

Table B.1 Static Test Results on Site A (Silty So1ls) ............. 


\section{LIST OF SYMBOLS}

A Projected surface area of anchor plate, $f t^{2}$

At-6 6-in triangular (arrowhead) anchor

B Width (or diameter) of anchor plate, ft

c Cohesion, $1 \mathrm{~b} / \mathrm{ft}^{2}$

D Average depth of anchor plate below ground surface, ft

Dv Average deptin of anchor plate below ground surface for full-depth vertical anchor, $f t$

D-4 4-in double helix anchor

H-3 3-in single helix anchor

H-6 6-in single helix anchor

n Number of specimens listed or number of load cycles

N Blow count in Standara Penetration Test, blows/ft

$N_{u} \quad$ Uplift capacity factor for cohesive 80118

$\mathrm{N}_{\text {qu }} \quad$ Uplift capacity factúr for granular 80118

$\mathrm{P}_{\mathrm{c}} \quad$ Cyclic load, 1b

$\mathrm{P}_{4 \mathrm{~h}} \quad$ Load at 4-in horizontal displacement, ib

P preload, 1b

$\mathrm{P}_{2 v} \quad$ Load at 2 -in vertical displacement, Ib

$P_{w} \quad$ Working load, 1b

P-6 $61 / 2 \times 11 / 4$ in pipe anchor

P-10 $10 \times 13 / 4$ in pipe anchor

q Anchor load capacity per unit anchor plate area, $1 b / \mathrm{In}^{2}$

$Q_{u} \quad$ Ultimate load capacity of anchor, ib 


\section{LIST OF SYMBOLS (Continued)}

$Q_{u}^{\prime} \quad$ Ultimate load capacity determined by pullout after completion of cyclic test, lb

$Q_{v} \quad$ Ultimate load capacity of full-depth vertical anchor, $1 b$

$\mathrm{R}_{10} \quad$ Reloading modulus of anchor after 10 load cycles, $1 \mathrm{~b} / \mathrm{in}$

R85 Reloading modulus of anchor at 85 percent of $Q_{u}, 1 b / 1 n$

STP Sol1 Test Probe

SPT Standard Penetration Test

s Shear strength of soll $1 \mathrm{~b} / \mathrm{ft}^{2}$

$\bar{s} \quad$ Average shear strength of soll, $1 \mathrm{~b} / \mathrm{ft}^{2}$

S Anchor shaft resistance, 1b

$t \quad$ Torque reading in STP test, in-1b

$\bar{t}$ Torque reading in STP test, averaged over anchor depth, in-1b

T Anchor installation torque, $\mathrm{ft}-1 \mathrm{~b}$

$v \quad$ Coefficient of variation of a sample. (The coefficient of variation of the population will differ considerably if the sample is sma11.)

$\alpha_{1} \quad$ Angle of applied load with horizontal, degrees

$\alpha_{2} \quad$ Angle of anchor shaft with horizontal, measured in same direction and the opposite quadrant of $\alpha_{1}$, degrees

$\gamma \quad$ In place unit weight of $8011,1 \mathrm{~b} / \mathrm{ft}^{3}$

$\Delta_{u} \quad$ Anchor head displacement in direction of pull at ultimate load, in 
In view of present accepted practice in the U.S. mobile home industry, common U.S. units of measurement are used throughout this report. The table below is presented to facilitate conversion to SI Units.

\begin{tabular}{llc} 
To Convert From & To & Nultiply by \\
\cline { 2 - 3 } $\mathrm{ft}$ & $\mathrm{m}$ & 0.305 \\
$\mathrm{In}$ & $\mathrm{mm}$ & 25.4 \\
$\mathrm{ft}{ }^{2}$ & $\mathrm{~m}^{2}$ & $9.29 \times 10^{-2}$ \\
$1 \mathrm{n}^{2}$ & $\mathrm{~mm}^{2}$ & 645.16 \\
$1 \mathrm{~b}$ (force) & $\mathrm{N}$ & 4.45 \\
$1 \mathrm{~b} / \mathrm{ft}^{2}$ (psf) & $\mathrm{Pa}$ & 47.88 \\
$1 \mathrm{~b} / \mathrm{in}^{2}$ (psi) & $\mathrm{kPa}$ & 6.89 \\
$1 \mathrm{~b} / \mathrm{ft}^{3}$ & $\mathrm{Kg} / \mathrm{m}^{3}$ & 16.02
\end{tabular}


FACING PAGE: Mobile home anchors pulled out by flood. The bent anchor shafts indicate that large horizontal force components acted on the anchors. 


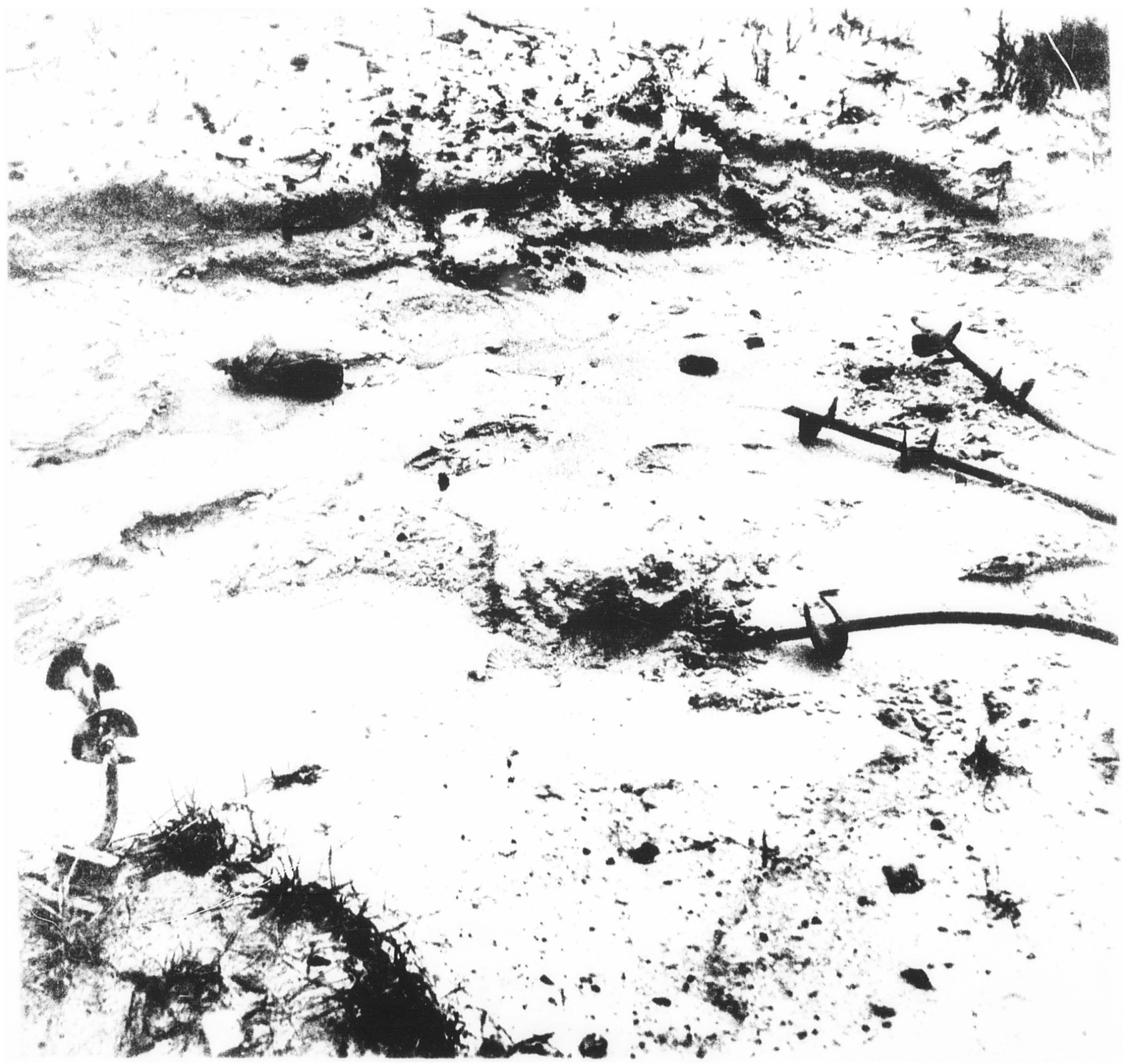

A foudat presently used to support mobile hones consists of pair itss, thout 8 to 10 feet on center, which support the chassis bears ot the lo hame unit, In addition, the mobile home is attached to soil an by trasverse over-the-roof ties and transverse diagonal ties attached rasis bean (see figure 1.1) The loads acting on this type of found taon boul studied by Yokel et al. [20]. The horizontal component of the w ind ad is resisted by the diagonal thes and by whatever horizontal-load c tistan is provided by the piers. Since piers are not normally designed 


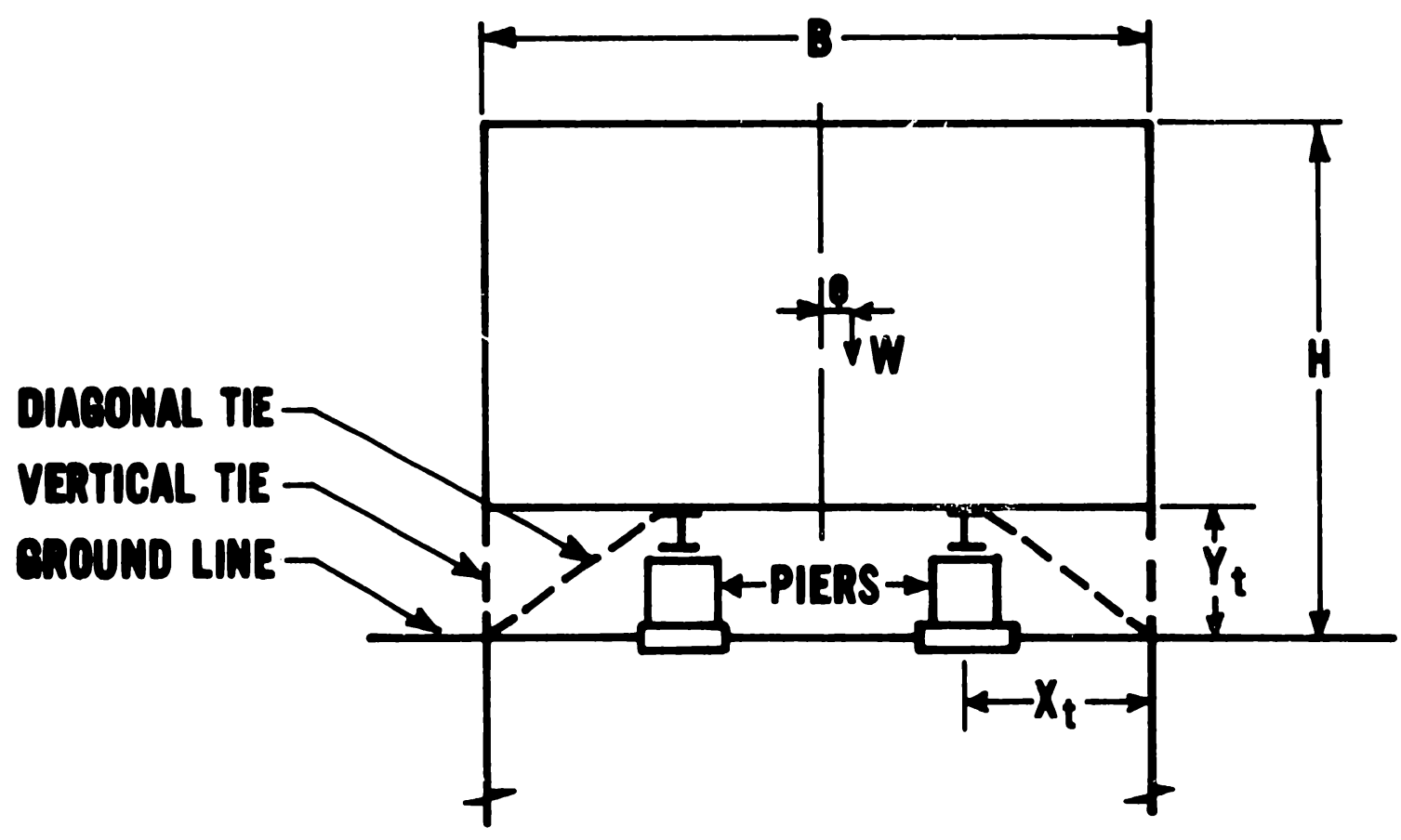

(a) - Near Tie Connection

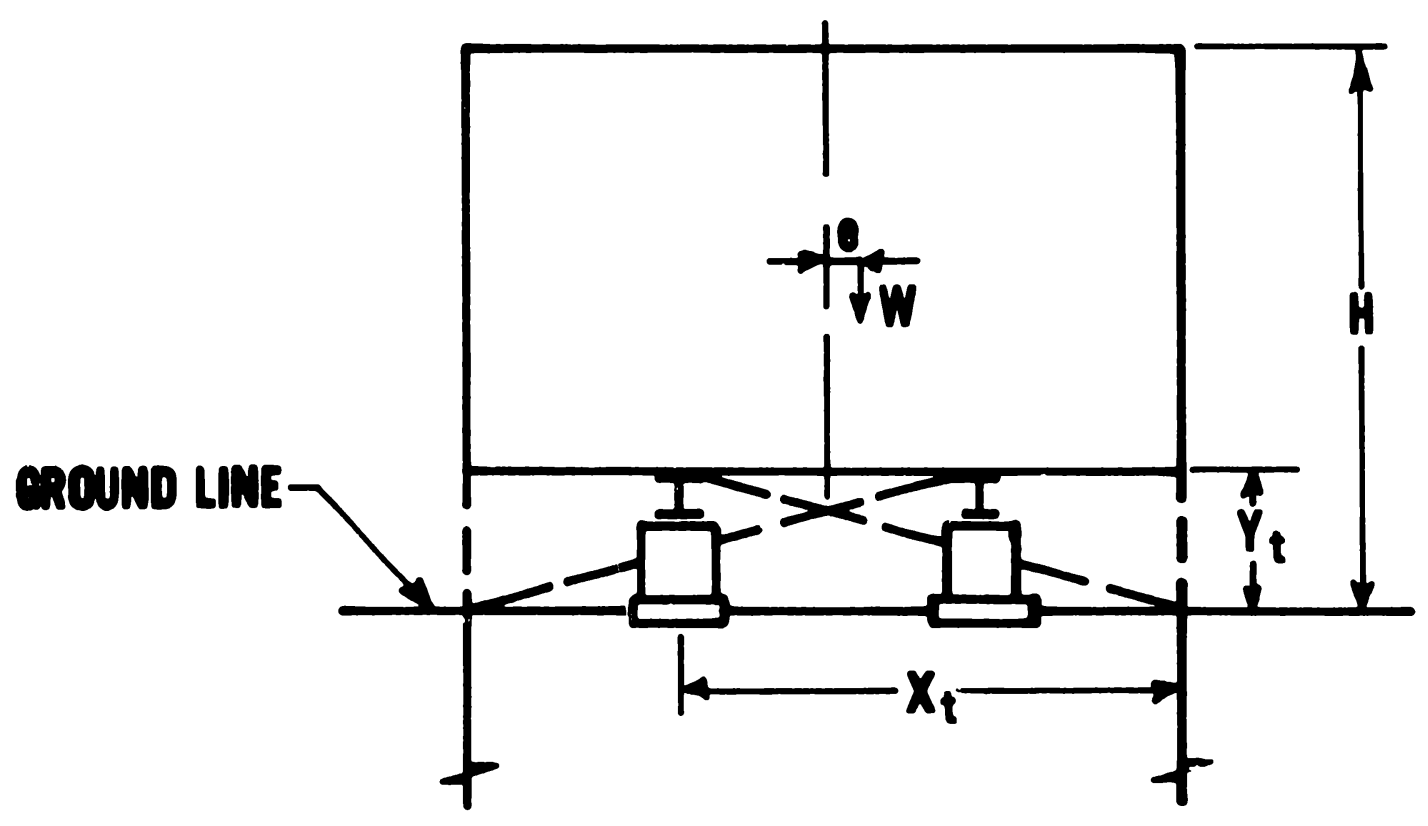

(b) - Far Tie Connection

Figure 1.1 Typical mobile home tiedowii systems 
to resist horizontal loads, the diagonal ties must provide the necessary horizontal-load resistance. The vertical over-the-roof ties are provided to resist uplift and overturning. It has been shown [20] that if the diagonal ties are attached to the chassis beams adjacent to the anchor [(figure $1.1(\mathrm{a})$ ], the vertical ties are not essential. However, the vertical over-the-roof ties help hold the mobile home together. The vertical ties are also engaged by uplift forces resulting from flooding and they must be used to resist windloads if the diagonal ties are attached as shown in figure 1.1(b). Thus, soil anchors must provide effective resistance to horizontal as well as vertical forces.

Present anchor technology was studied by Kovacs and Yokel [12]. The anchors most frequently used by the mobile home industry are single helix, 6-in diameter anchors installed to a 4-ft maximum depth and double helix 4-in diameter anchors installed to a $2 \mathrm{ft}-9$ in maximum depth (figure 1.2). Other types of anchors are also available, but not extensively used at the present time. Miscellaneous hypotheses have been developed which correlate the load capacity of anchors to the shear strength of solls, which in turn can be measured by various in-situ and laboratory tests. However, it was concluded on the basis of avallable data that the correlation between calculated and measured anchor-load capacities, particularly in g anular solls, tends to be poor [12]. In part, our inability to make reliable predictions of anchor-load capacity on the basis of the shear strength of solls is attributable to our inability to make reliable measurements of the in-situ shear strength, particularly that of granular solls. This measurement problem is even more severe at shallow depths, where solls are subjected to many disturbances, such as freezing and thawing, changing molsture content and the effect of root systems and organic matter. Moreover, the most commonly used in-situ test, the Standard Penetration Test (ASTM D 1586) [4] is difficult to interpret at a shallow depth because of the short drill-stem length used [15].

In present practice, the load capacity of mobile home anchors is estimated on the basis of in-situ soll test probe (STP) measurements, coupled with predictions based on the results of pull-out tests conducted in solls with characteristics similar to that of the site. Guidance for this procedure is provided in ANSI Standard Al19.3 [2] and in miscellaneous charts published by industry [7]. ANSI Standard Al19.3 stipulates in section 4.5 .1 that a ground anchor, when installed, shall be capable of resisting an allowable working load at least equal to $3,150 \mathrm{Ib}$ in the direction of the tie, plus a 50 percent overload $(4,725 \mathrm{lb}$ total) without fallure. Fallure is defined as an anchor movement of 2 inches at $4,725 \mathrm{lb}$ in the direction of the vertical tie. Anchors which are designed for loads other than "direct withdrawal" (coaxial loads) shall resist an applied design load of $3,1501 \mathrm{~b}$ at $45^{\circ}$ from the horizontal without displacing the anchor more than 4 inches horizontally at the point where the tie is attached to the anchor. Anchors designed for connection of multiple ties shall be designed to resist the combined working load and overload consistent with the intent expressed in section 4.5 .1 . The magnitude of the stipulated load capacity in ANSI Al19.3 is entirely predicated on the load capacity of presently used steel straps with no regard to whether existing soll anchor technology can provide the stipulated load resistance. 


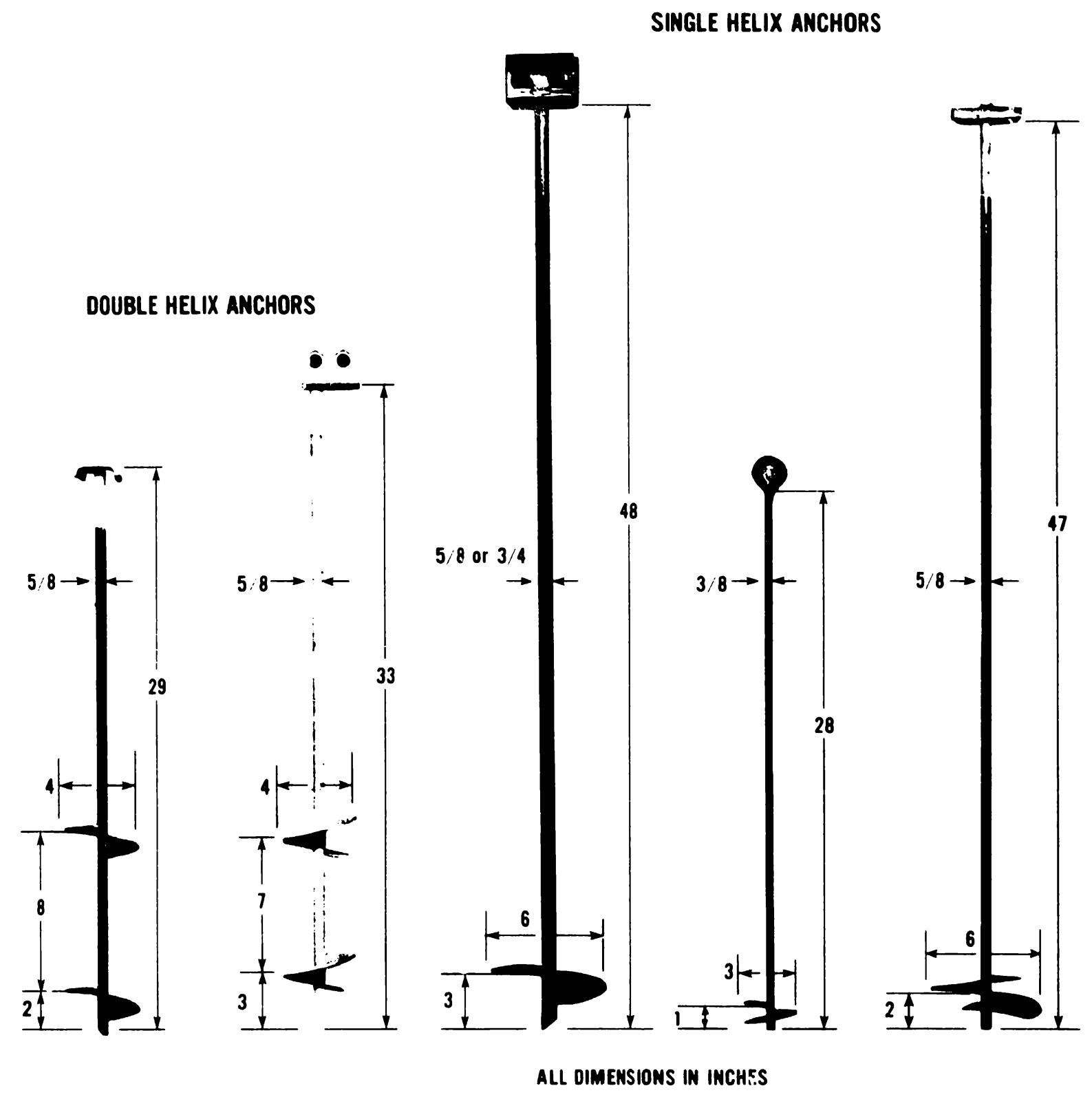

Figure 1.2 Single and double helix anchors 
There is evidence that in present practice withdrawal tests are conducted in accordance with the first part of this provision, namely coaxially, and that the anchor capacity is then determined for a 2 in withdrawal. Most avallable data are limited to this test condition, and therefore do not provide much information on anchor capacity under larger displacements or under incilned loads which have a component normal to the axis of the anchor.

Provisions for mobile home anchors are generally enforced by the States. These provisions are not uniform throughout the United States; some States have no provisions, while others, like Texas [17] require that the anchor resist a load "In the direction of the expected applied loads" of 4,725 1b for single headed anchors and $6610 \mathrm{lb}$ for double headed anchors. In the Texas provision, "fallure" is defined as a movement of 3 inches in the direction of the axis of the . anchor. This relaxes the more stringent linitation of 4 inches on horizontal movement and 2 inches on axial movement provided in ANSI 119.3. Proof of compliance with the various State provisions can generally be provided by anchor manufacturers or installers by documenting the results of withdrawal tests conducted in soils with characteristics similar to those of the site. Some States will accept the results of tests in artificlally prepared soils. Implicit in the use of withdrawal tests as proof of compliance in similar soll conditlons are two assumptions:

1. That soll conditions can be characterized well enough so that anchor capacity on a given site can be predicted from test results on similar sites.

2. That anchors w111 have satisfactory load-displacement characteristics in the horizontal, as well as the vertical direction.

The objective of the test program presented herein was to study the performance characteristics of the most common types of mobile home anchors and to determine how adequate performance can be assured. 
FACING PAGE: $x-y$ recorder used to plot anchor test results in the field. 


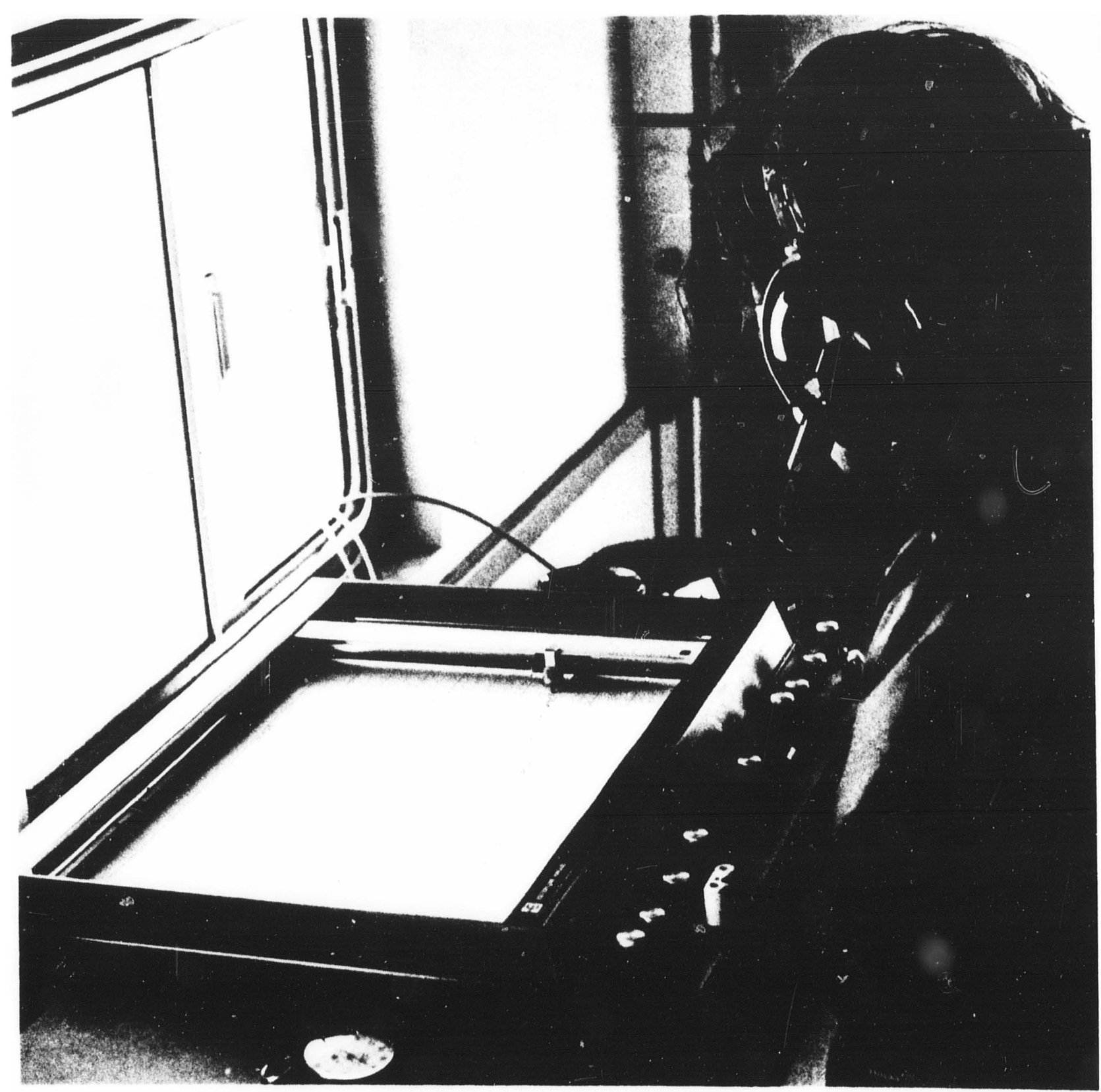

2. $\mathrm{SCOPE}$

Two hundred and thirty-two anchor tests were conducted on the three sites: a sandy site; a silty site; and a clav site. Two hundred and nineteen of these tests were conducted with single and double helix anchors and 13 tests were conducted with self-seating swivel anchors (trianqular and pide). Of these tests, 179 were pullout tests using vertical and inclined axial pulls and inclined pulls at an anale to the anchor shaft; 53 were cyclic tests using several hundred equal loading cycles of vertical coaxial pull or inclined pull at an angle to the anchor shaft. 
The soil characteristics of the test sites were determined by two types of in-situ tests: the Standard Penetration Test (ASTM D 1586); and the Soil Test Probe (refer to ANSI Al19.3). In addition, disturbed and undisturbed soil samples were analyzed and tested in the laboratory.

Test results were recorded electronically by an $x$ - y plotter as a plot of applied load vs. displacement of the point where the tie is attached to the anchor. Most static tests were carried to complete anchor withdrawal with several intermediate cycles of unloading and reloading in order to provide information of the load-displacement characteristics to the point of incipient loss of load capacity. Cyclic tests were conducted at various load levels and in most instances carried to a point where the probable trend of response to additional load cycles is apparent. Throughout the test program emphasis was placed on the effect of pre-loading on anchor response. Several tests were conducted under subnerged conditions in order to study the effect of flooding on anchor capacity.

In this report all the test results are presented in tabular form. In the analysis of the test results, anchor load capacity is correlated with soil strength as measured by in-situ and laboratory tests and an assessment is made of our ability to predict anchor-load capacity. Anchor performance characteristics in various soll types are compared and studied and methods of insuring adequate anchor performance are recommended..

FACING PAGE: Cyclic load test on Site B. The test rig is in the foreground. Behind the test rig is the oil pump used for cyclic loading. The van in the background housed a generator and data acquisition equipment. Note the 20-6t high banks surrounding the borrow pit in which site $B$ was located. The original ground surface can be seen on the top of the bank. 


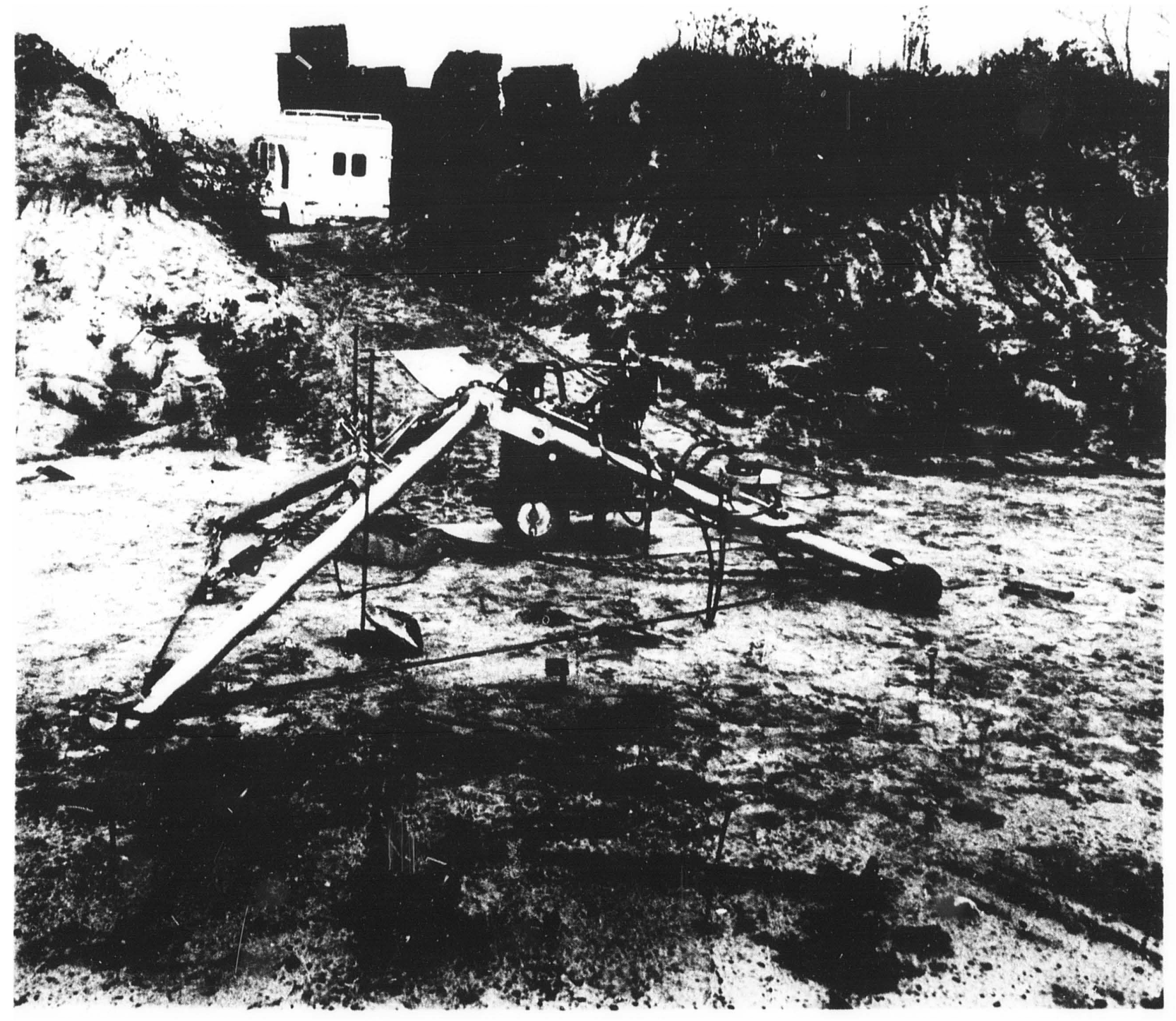

\section{TEST SETUP AND PROGRAM}

\subsection{DESCR IPTION OF TEST SITES}

\subsubsection{General}

There was prior evidence that performance characteristics of soll anchors depend on the type of soil in which the anchors are embedded [12]. Thus, it was important to test anchors on sites with a variety of soll characteristics. It was therefore decided to choose three different sites: a silty site (A), a 
sandy site (B), and a clay site (C). The three sites selected are listed in table 3.1. Plans showing anchor test and soil-boring locations, as well as test reports containing boring logs and soil test data are included in appendix A. Pertinent site characteristics are described hereafter.

Table 3.1 Test Sites Selected

Site Predominant Soll Type

A

B

C
Silt

Sand

Clay
Location

NBS grounds, Gaithersburg, MD

Odenton, MD

Upper Marlboro, MD

\subsubsection{Test Site A, Silty Soils}

Test Site A was explored by eleven 5-ft deep test borings. The borings generally indicate $2 \mathrm{ft}$ of fill consisting of local silty material

overlying residual silty suil and quartz-rich schist of the Wissahickon Formation. No groundwater accumulated in the borings during, and up to 5 hours after, the drilling. On the basis of visual observation and laboratory analysis, the soll can be described as brown stiff clayey silt with some fine sand and quartz fragments, and classified as Group ML in accordance with the Unified Soil Classification System (ASTM D 2487 [5]).

Laboratory tests indicate that the soils consisted of 62 to 83 percent by weight of materials passing No. 200 sieve (particle size smaller than $0.074 \mathrm{~mm}$ ). The liquid limit and plasticity, index were 39 and 12 percent, respectively. The SPT "N" values ranged from 7 to 19 blows per foot. Laboratory strength tests determined an unconfined compressive strength of 4000 psf at 4 percent strain. Direct shear tests provide some additional information. Measured natural wet density was $1191 \mathrm{~b} / \mathrm{ft}^{3}$ and dry density was $981 \mathrm{~b} / \mathrm{ft}^{3}$.

\subsubsection{Test Site B, Sandy Soils}

Test Site $B$ is located at the bottom of an excavated borrow pit and was explored by four $10 \mathrm{ft}$ deep test borings. No water accumulated in the borings to the depth where the holes caved, which ranged from 5 to $6.5 \mathrm{ft}$. The deposits on this site can be traced to the Potomac Group which generally consists of interbedded sands and silty clay layers of cretaceous origin which characteristically are overconsolidated. The sands in this formation tend to be medium dense to dense and the silty clays stiff to hard. The borings indicate a 6 to $9 \mathrm{ft}$ thick layer of moist fine-to-course clean sand which rests on sandy silty clay. On part of the test site the above-mentioned sand layer is covered by a 0.5 to $1.0 \mathrm{ft}$ thick crust of dense silty sand fill with gravel. Most of the anchor tests were performed in locations that were not covered by 
the dense crust. The 6 to $9 \mathrm{ft}$ sand layer can be described as light brown medium dense fine-to-coarse sand with a trace of silt and gravel and classified as Group SP in accordance with ASTM D 2487.

Laboratory tests Indicate that the sand deposit had 95 percent by weight of material in the range between No. 4 and No. 200 sieves (particle sizes betreen 4.699 and $0.075 \mathrm{~mm}$ ), a natural moisture content of 2 to 4 percent and a natural dry density of 92 to $95 \mathrm{lb} / \mathrm{ft}^{3}$. The SPT "N" values over a $5 \mathrm{ft}$ depth below ground ranged from 10 to 21 blows per $\mathrm{ft}$. Consolidated undrained triaxial compressive strength tests on reconstituted samples yielded an angle of shearing resistance $\phi=31^{\circ}$. The $\phi$ value obtained from direct shear tests was approximately $29^{\circ}$.

The dense crust had natural dry densities from 105 to $1.081 \mathrm{~b} / \mathrm{ft}^{3}$ and SPT "N" values from 20 to 40 blows per foot.

\subsubsection{Test Site C, Clayey Soils}

Test site $C$ was explored by four test borings from 5 to $5.5 \mathrm{ft}$ deep below ground. Groundwater was observed in all the borings upon completion of the drilling at depths ranging from 1 to $4 \mathrm{ft}$. While no long-term groundwater observations were made, it was noticed during the field testing that the groundwater table was near the surface. The site is a wooded tract and root systems were encountered on some of the tests. The deposits on Site $c$ are believed to be rleistocene river terrace deposits of the Western Branch of the Patuxent River and generally consist of silty clays overlying sands. On the basis of fleld observation and in-situ and laboratory tests, the soil is described as a grey, medium stiff to stiff silty clay, with traces of sand and organic matter and classified as Group CL in accordance with ASTM D 2487.

Laboratory tests indicate 70 to 90 percent of material passing No. 200 sieve (particle size smaller than $0.074 \mathrm{~mm}$ ) and a natural moisture content of 23 percent. Natural dry density varied from 92 to $1001 \mathrm{~b} / \mathrm{ft}^{3}$. The liquid 1imit varied from 27 to 39 percent and the plasticity index varied from 7 to 19 percent. Standard Penetration Test " $\mathrm{N}$ " values varied from 2 to 17 blows per foot. Unconsolidated undrained triaxial compression tests on an undisturbed sample yielded a c of $700 \mathrm{psf}$ and a $\phi$ of $19^{\circ}$. An unconfined compression test yielded an unconfined compression strength of 1930 psf at 6.7 percent strain.

\subsection{TEST SPECIMENS AND PROCEDURES}

\subsubsection{Anchors Tested}

Most anchors tested were of the helical type with 6-in single or 4-in double helixes welded to nominal $5 / 8$ in or $3 / 4$ in shafts. A few tests using three inch single helixes welded to a $3 / 8$ in shaft were used to investigate size effects. See figure 1.2 (page 4) for typical sizes. 
Fourteen self-seating swivel (fluke) anchors were also tested. Ten of these were pipe segments of two different sizes (10.25 in long by 1.75 in outer diameter and 6.5 in long by 1.25 in outer diameter) and four were triangularshaped (arrowhead) plate anchors with 6 in side lengths. See figure 3.1 for detalls. All the anchors used were commercially avallable anchors furnished by Industry.

\subsubsection{Test Apparatus}

The anchor tests were performed by the test rig developed for the project as shown In figure 3.2 which has the capability to exert a $10,0001 \mathrm{~b}$ vertical or inclined pull against the anchor head. The pulling force can be exerted at an angle to the horizontal of $15^{\circ}$ or steeper. The test rig consists of an aluminum tripod with extendable legs (one $4 \mathrm{ft}$ long segment and one $3 \mathrm{ft}$ long segment; in the figure the legs are fully extended). At the apex of the tripod a pulley 18 Instailed on a removable axle which is attached to the main leg of the tripod. The anchor is pulled by a chain which passes over the pulley and is attached at one end to the anchor head and at the other end to a pair of push-pull rams which are connected back to back to achieve a long stroke.

The plunger ends of the rams are fitted with a clevis eye and a chain hook, respectively. The clevis eye is attached to a bracket welded to the main leg of the tripod and the chain hook is grabbing the most convenient link of the pulling chain. The rams are designed for a maximum pressure of $10,000 \mathrm{psi}$ which develops a pulling force of $9,8001 \mathrm{~b}$. The $1 / 2-$ in thick pulling chain with electro-welded links has a load capacity of 15,000 1b. It was used for pulling because it was readily avallable and had convenient accessories which made it easy to make length changes as needed.

The front legs of the tripod can be attached to the main leg in two places: they can be attached to the removable pulley axle shown in figure 3.2 , or to another location $1 \mathrm{ft}$ down on the main 1 eg which is shown in figure 3.3. This second configuration, which projects the pulley on a $1 \mathrm{ft}$ cantilever, together with the shorter ( $4 \mathrm{ft}$ ) leg length can be used to pull anchors installed under a mobile home. When attached to the axle, the front legs are spread at a f1xed $90^{\circ}$ angle. The angle between the front legs and the main leg can be adjusted by rotation about the axle.

The tripod 18 designed to withstand a 10,000 $1 \mathrm{~b}$ pull when the legs are spread 80 wide that the pulley axle is only $1 \mathrm{ft}$ above ground. In any other position the load capacity would be greater. Except for the pulley and axle, the tripod 18 fabricated from $6061 \mathrm{~T} 6$ high strength aluminum alloy. The legs are made of 4 in diameter tubing. The front legs have a $1 / 8$ in wall thickness and the main 1 eg has a $1 / 2$ in wall thickness. The yoke carrying the pulley and axles, as well $a 8$ the end sestions of the legs are made of solid aluminum.

The legs are restrained from spreading by a $3 / 8$ in thick galvanized aircraft cable and an 8-ft length of chain. The restraining cable that connects the front legs has a fixed length, since the angle between the front legs is fixed 


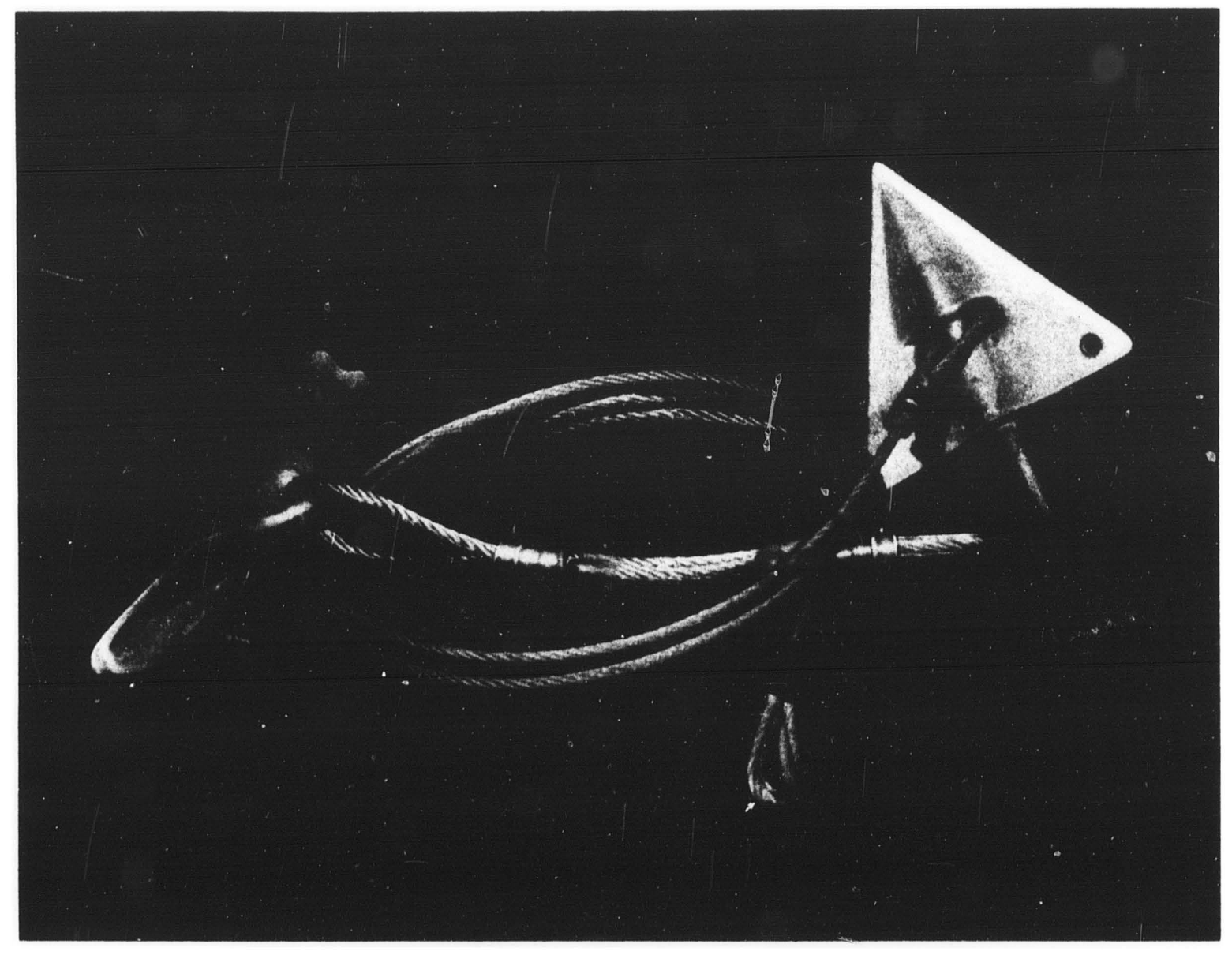

Figure 3.1 Self seating swivel anchors (triangular and pipe) used in the test program 


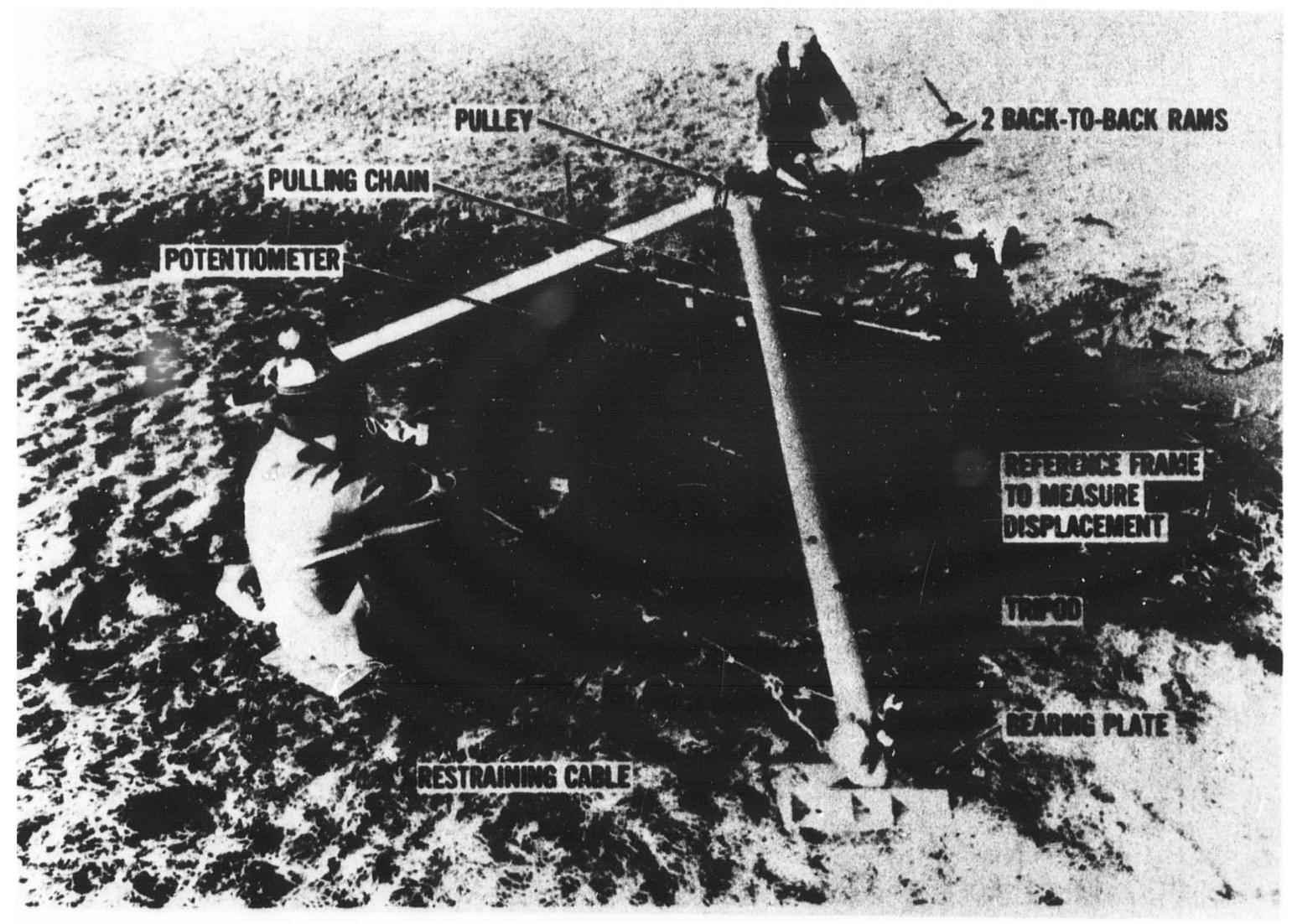

F1gure 3.2 Test rig 


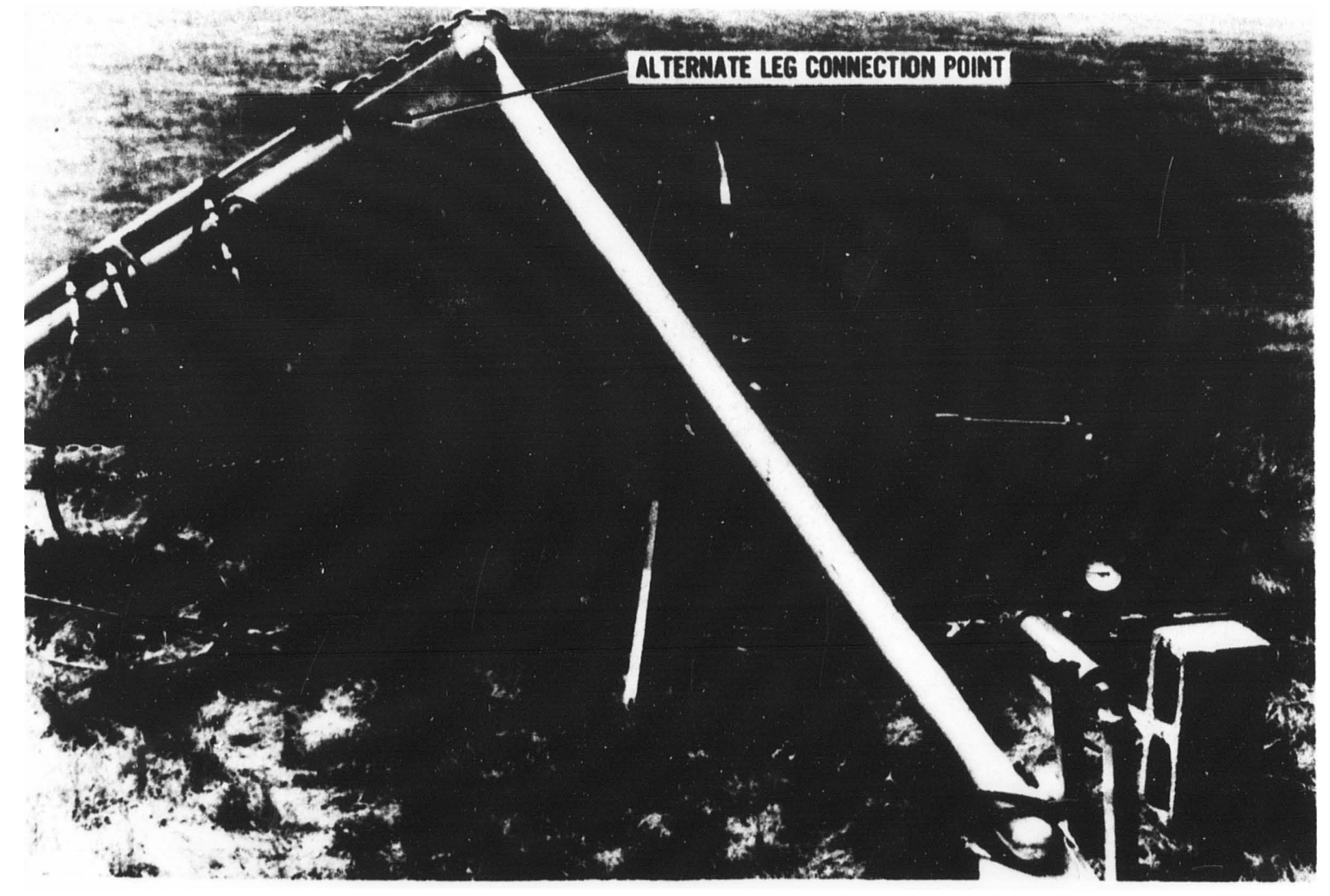

Figure 3.3 Detalls of test rig 
at $90^{\circ}$. The restraining chain with another segment of cable connects the main leg to the front legs, and is adjustable to accommodate any desired angle between the main 1 eg and the front legs. The restraining chain and cables are designed to resist the forces generated by a 10,000 $1 \mathrm{~b}$ pull in the most unfavorable (lowest) tripod position.

Bearing plates of $1 / 2$ in thick aluminum, 9 in wide by 19 in long, are used to support the legs of the tripod. The plates used under the front legs have a $2 \times 2 \times 1 / 4$ in aluminum angle welded to the long edge of the top surface of the plate to resist sliding when the tripod is used for inclined pulling. Two aluminum stakes are driven into the ground in front of each bearing plate to provide resistance to lateral forces in angular pulls.

The hydraulic pressure is generated by one of two pumps, depending on the type of testing. For the slow rate (monotonic) testing, a double-acting hand pump is used that has 10,000 psi capability and a useable oil capacity of $126 \mathrm{in}^{3}$. A bourdon tube type gage is used for visually monitoring hydraulic pressure. The cyclic testing is done using an electrically driven hydraulic pump mounted on pneumatic tires for rough terrain use. It has a pressure capability of 10,000 psi and a five gallon useable ofl supply. The cyclic application of hydraulic pressure is controlled by a program control center having five variations of programmed load application, holding, and removal. A continuous cycling program is used that steps through load application to a given load level, holds the load for a given time, retracts the ram to a position that insures complete removal of the load, counts the cycle and then repeats the cycle.

Suitable signals are provided to the control center by an adjustable pressure switch, a timer, a snap-action limit switch, and an automatic cycle counter. The electricity necessary for running the pump motor, the controller and the instrumentation 18 provided by a gasoline powered generator mounted on a van which is used to transport the equipment and to serve as a field laboratory that houses the electronics and data recording equipment.

The electronics used consists of a pressure transducer for neasuring hydraulic pressure, a 10,000 1b universal load cell, a pair of linear potentiometers and/or a pair of constant-tension cable position transducers to measure anchorhead displacements, an $x-y$ recorder, a volt-ohm meter and a recorder checker. The pressure transducer has a $0-10,000 \mathrm{psi}$ range and is the high output semiconductor instrumented diaphragm type with an output of $25 \mathrm{mv} /$ volt full scale. This device is used primarily in the monotonic tests to measure the hydraulic pressure that translates into pulling force. The load cell is used in tension to measure the pulling force between the chain and the head of the anchor and is used in the cyclic tests. Its output is $3 \mathrm{mv} / \mathrm{volt}$, full range. The linear potentiometers have a 10 in travel that varies the voltage linearly through the stroke. Electronically the resistances of the two potentiometers are combined to indicate average movement in case the anchor head tilts or rotates. The cable position transducers are also used in the averaging mode for the same reason. These devices are ten-turn precision rotary potentiometers that have a known-diameter pulley mounted on their shafts. A constant tension cable 
take-up assembly was used in conjunction with the potentiometers by having the cable make one turn around the pulley before exiting the mounting housing. These instruments have many advantages: 1 . The stroke can be chosen by changing drive pully diameter; 2 . Constant tension makes calibration easy by simply inserting a calibrated length tension 1ink; 3. The constant tension cable device is not influenced by imprecise alignment. The diameter of the pulley used produces a 25 in maximum travel in the test set-up. The recorder checker is used to produce precise voltage for callbration of the $x-y$ recorder.

\subsubsection{Testing Procedure}

The anchors were installed in a grid pattern in a predetermined area having a a 5 foot grid line spacing (see appendix A). Vertically-installed anchors were spaced $5 \mathrm{ft}$ apart and anchors installed at an angle were spaced at $10 \mathrm{ft}$. The helical anchors were turned into the ground by an electrically-driven installation tool that turned at nine revolutions per minute. Two 18 in handles were provided on opposite sides of the installing tool to enable two operators to react against the turning torque. Final installation torque was measured with a 0-600 ft 1b torque wrench and recorded on the data sheet. The self-seating swivel anchors were installed with an automatic hammering device and a drive rod. Soll test probe readings (STP) were taken at 1 -ft depth intervals to the full depth of the probe $(48 \mathrm{ln})$. Test probe readings were taken midway between every second pair of anchors. Generally, only enough anchors for one day's testing activity were installed at one time. The tripod was then brought into the position that produced a pull in the desired direction. The bearing pads were placed under the ends of the legs and on angular pulls the stakes were driven into the soll to counteract the pulling force. Two weighted ring stands with an interconnecting rod were used to support the position transducers used to measure anchor movement (see figure 3.2). These position transducers were mounted on opposite sides of the pulling chain in such a way that they measured movement in the direction of the pull. The attachment of the chain to the head of the anchor simulated the typical mobile home tle-down attachment as closely as possible. An approprlate yoke was placed on the anchor head or on the shaft just under the head, protruding from opposite sides of the anchor, to accommodate the attachment of the position transducers. The hydraulic pressure and return lines were attached by means of quick-disconnect couplers. Signal cables from the pressure transducer (or load cell in the cyclic tests) and the position transducers were then connected by mating couplers to the $x-y$ recorder and power supply in the van. Sound powered headphones were used for communicating between the pump operator and the recording technician. After a short calibration check, the test was started.

The monotonic tests were performed at a loading rate of $600 \mathrm{lb}$ per minute until the load capacity of the anchor dropped. At this time, the anchor was pulled out at any convenlent speed. Movement of the head of the anchor and the corresponding load were recorded as a load deflection curve plotted on an $x-y$ recorder. 
The cyclic tests were performed using the same type anchors, installation procedures and pulling configurations as the monotonic tests. The equipment used was described in section 3.2.2. Most cyclic tests were preceeded by one static load cycle to 83 percent of ultimate load capacity (this level is herein called the preload level.) The ultimate load capacity was taken as the average of previously performed adjacent static tests with the same loading configuration. The load level was then adjusted to two-thirds of the ultimate load (the estimated "design" load) or to other predetermined load levels, and 200 to 300 load cycles were applied. The rise time of a load cycle was generally 30 seconds and the peak load was maintained for $21 / 2$ seconds. The specimen was unloaded after each load cycle. The preloading cycle and the first five or ten cycles were recorded on the $x-y$ recorder and subsequent cycles were visually monitored with the recording pen lifted off the paper. Perlodic cycles (every 20th, every 50th) or signif cant events such as increasing creep or incipient fallure were recorded by returning the pen to the paper. This practice allowed recording of the rate of creep and important events without covering the paper with repetitious lines.

\subsection{TEST PROGRAM}

\subsubsection{Genera1}

Anchor performance is affected by many variables and it was realized early in the project that thousands of tests would be needed to obtain a statistically significant number of tests for each condition. It was therefore decided to conduct a more extensive test program on the silt site (Site A) and keep the number of tests on the other two sites to a minimum.

\subsubsection{Test Variables}

The test variables considered were: anchor type; anchor size; anchor depth; loading conditions; load orientation; soil type; and soll conditions. These variables are discussed hereafter.

\section{(1) Anchor Type:}

Several anchor types suitable for mobile home application are commerically available [12]. Presently the most frequently used anchors are the 6 in diameter single-helix and the 4 in diameter double-helix anchor. Very few data were available for these anchors, and the available data provided only 1imited information [12]. Another type of shallow anchor which could be adapted for mobile-home use is the self-seating swivel anchor. These anchors were extensively used by the Armed Forces and, as a consequence, more test data were available. It was decided to conduct most tests with single- and double-helix anchors and a limited number of tests with self-seating swivel anchors. 


\section{(2) Anchor Size:}

Anchor size has a major effect on load capacity. It is generally assumed [12] that anchor-load capacity is proportional to the area of the anchor plate which provides resistance to pullout. To study this parameter, several tests were conducted with 3 in diameter single helix anchors. The result of these tests can be compared with those obtained from tests on 6 in single helix anchors. The 3 inch anchor is not used for mobile homes because of its inadequate load capacity.

\section{(3) Anchor Depth:}

It has been determined in previous investigations [12] that there are two types of fallure mechanisms for soll anchors: the so-called "shallow" anchors fail by pulling with them a body of soll (cylinder, truncated cone or other) which extends to the ground surface; the so-called "deep" anchors fail without causing a substantial disturbance at the ground surface, since the fallure (slip) surface surrounding the anchor does not extend to the ground surface (one study also identifies "intermediate" anchors [8]). As a consequence, the change of load capacity with depth differs for these two types of anchors, and different models for predicting load capacity have to be used. The ratio of anchor depth to anchor diameter $(D / B)$ at which an anchor becomes a "deep" anchor has been estimated to vary from about 4 to 8 [14] and it is therefore not clear whether mobile home anchors can be classified as shallow or deep. Several comparative tests were performed to investigate this parameter, using anchor depths from 1 to $4 \mathrm{ft}$.

\section{(4) Loading Conditions:}

Three loading types were under consideration:

1. Monotonic load cycles, sustained for relatively short periods of time

2. Cyclic loads

3. Long-term substained loads

Under actual field conditions, wind would cause one or two cycles of some maximum load sustained for one or several seconds and many cycles of lesser load; floods would probably cause one load cycle with a relatively slow rise time and sustained for some period of time, ranging from several minutes to several hours; long-term sustained loads could be caused by swelling soil conditions or frost heave.

Since swelling and frost heave effects can not be quantified, and it is also reasonable to anticipate that periodic relaxation and re-tightening of straps as a maintenance procedure would be necessary if such effects are experienced, it was decided not to conduct tests for this loading condition. 
To assess windload effects, it is important to get an appreciation of the cyclic-load effects associated with a windstorm. An examination of the stripchart recording of Hurricane Frederick ${ }^{2}$ indicates that the maximum wind velocity at the gaging station ( $86 \mathrm{mph}$ ) occurred twice during the 7-hour period of high winds; a wind pressure equal to 75 percent of the maximum was exceeded 10 times; a wind pressure equal to 60 percent of the maximum pressure was exceeded 86 times; and a wind pressure equal to 50 percent of the maximum pressure was exceeded 162 times. Thus, it was decided that test data from 100 to 200 successive load cycles would provide adequate information to assess the probable effects of a major hurricane. Cyclic loads applied ranged from 50 to 75 percent of the ultimate-load capac $y$ of the anchor. Initially, it was planned to perform monotonic and cyclic-load tests. Later in the program, several cycles of unloading and reloading were included in the monotonic tests in order to evaluate strain-hardening effects.

\section{(5) Load Orientation:}

Most anchor-test data available are for pullout in the direction of the anchor sha!:t. However, as shown in the NBS load study [20], the most important function of mobile-home anchors is to resist horizontal loads. Since most helix anchors are installed vertically or near vertically, and the horizontal load is transmitted to the anchor by a strap which is installed at an angle ranging from $15^{\circ}$ to $60^{\circ}$ to the horizontal, it is necessary to study anchor performance under this loading condition. To explore the full range of conditions that could be encountered, vertical anchors were subjected to vertical, as well as inclined loads, and anchors installed in an inclined position were subjected to loads in the direction of the shaft, as well as loads normal to the direction of the shaft.

\section{(6) Soil Types:}

A great number of soll types are encountered in nature, and oversimplification cannot be avoided if an attempt is made to condense these into a few typical cases. There is evidence [12] that there is a fundamental difference between anchor performance in granular and cohesive soils, since these solls have different strength, drainage, and strain hardening characteristics. The three soil types selected for this project were discussed in section 3.1 .

\section{(7) Soll Condition:}

Soll condition is an important variable, since moisture content changes seasonally on many sites. In this project two conditions were investigated: the in-situ condition, which did involve some minor fluctuation in water content during the duration of the tests, and the submerged condition which was

2 The records were taken on September 13, 1979, at Mobile, Alabama, Muncipal Airport in open terrain and obtained from the National Weather Service Station in Mobile, Alabama. 
either obtained by existing site conditions, or artificially induced by flooding. The submerged condition is important since it is necessary to determine whether anchor capacity is reduced under flood conditions.

\subsubsection{Summary of Test Program}

Table 3.1 provides a summary of the test program. To avoid complexity, the parameters explicitly noted were anchor type, soil type, loading condition and load orlentation. Anchor size, anchor depth, and soll condition were omitted. These parameters are identifled in appendix $B$ where all the test results are presented.

TABIE 3.1 SUMMARY OF TEST PROGRAM

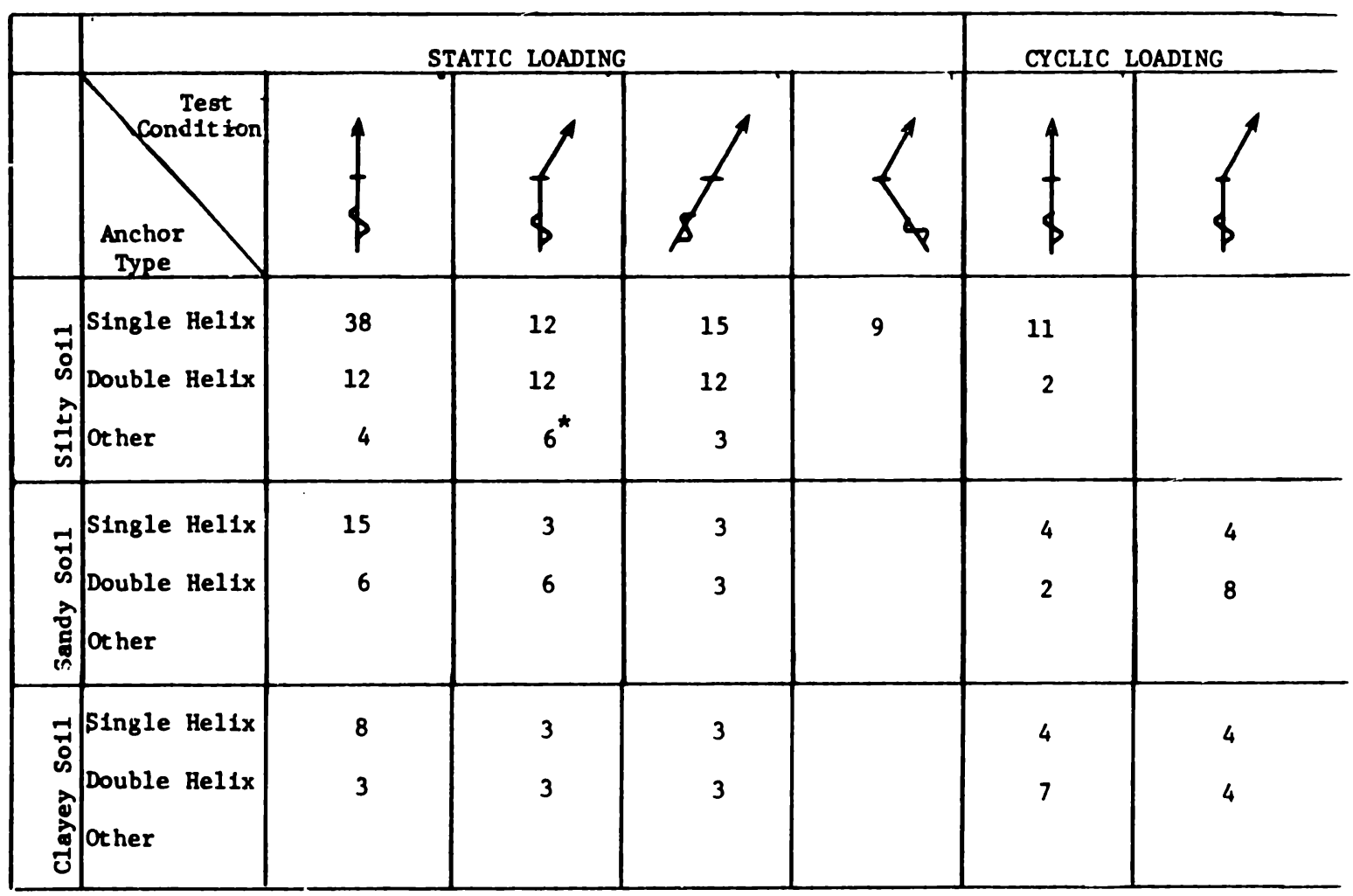

These anchors were self-seating swivel anchors. The anchor itself was inserted vertically. However, when the test load is applied, the connecting cable aligns Itself in the direction of the load. 
FACING PAGE: Installing vertical anchor on site $A$. 


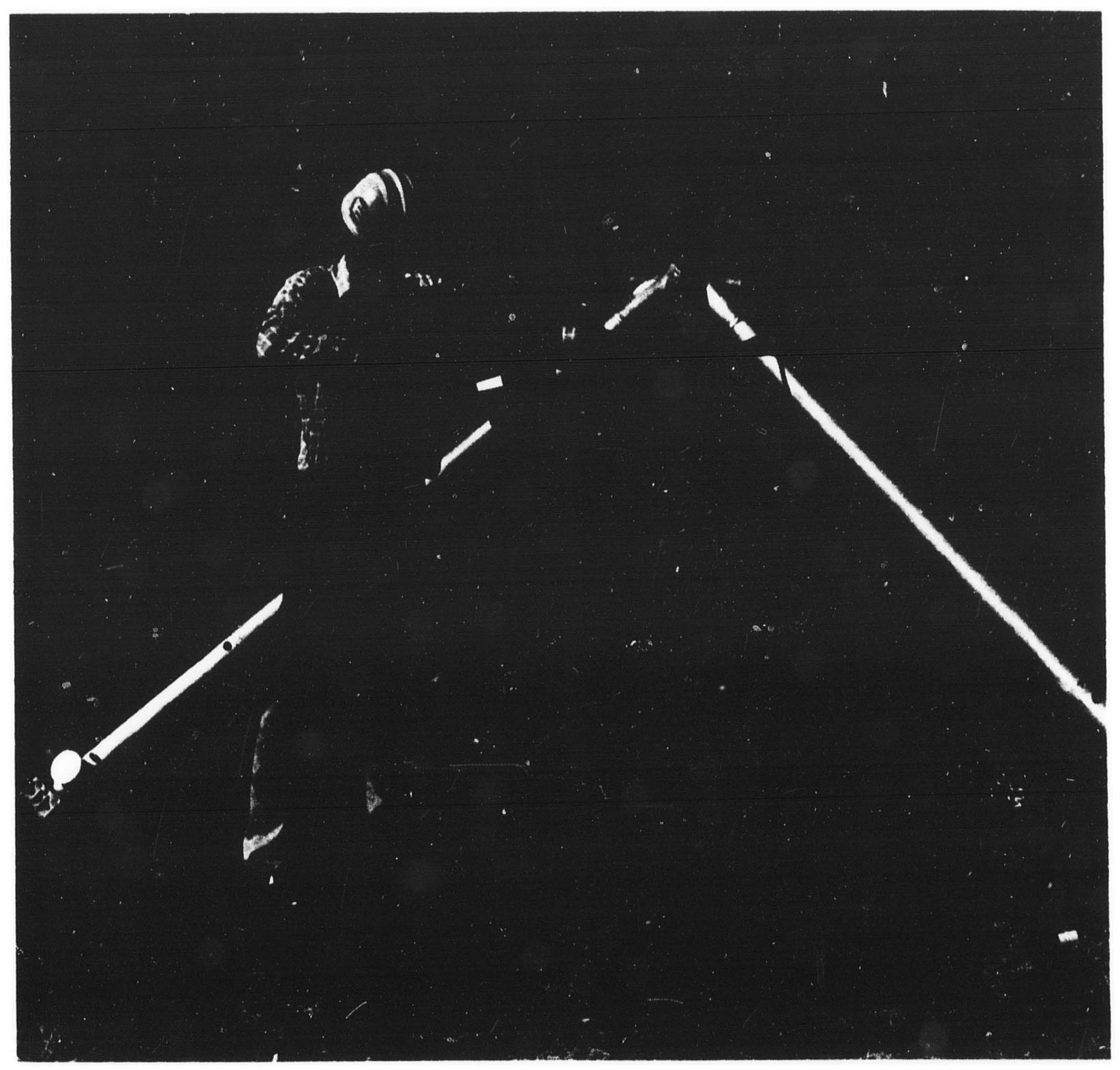

\section{ANALYS IS OF TEST RESULTS}

\subsection{PRESENTATION OF RESULTS}

The test results are presented in appendix $B$. The data were electronically recorded in the field by an $x-y$ plotter in the form of load versus displacement. The resolution of these plots permitted an estimate of displacement to the nearest 0.01 in and loads to the nearest $0.01 \mathrm{kip}$. This resolution was compatible with the accuracy of the measurements. Since it would be impractical to reproduce the resulting 232 plots in the report, data points that 
were derived from the plots are presented in tabular form in tables B.1 through B.6.

Results from the monotonic loading tests are given in tables B.1., B.3 and B.5. Each test is identified by letters and a number. The letters idencify the site: $S T=s i l t, S D=$ sand and $C=$ clay. The test identification is followed by test location coordinates. The corresponding locations are identified in appendix A. The third column identifies the anchor type. $\mathrm{H}-6, \mathrm{D}-4$ and $\mathrm{H}-3$ mean 6 in single hellx, 4 in double helix and 3 in single helix, respectively, AH means arrowhead (triangular) anchor and $P 10$ and $P \quad 6$ mean $101 / 4$ and $61 / 2$ in long pipe anchors. (The arrowhead and pipe anchors are self seating swivel anchors.) The anchors are iurther identified by make (only identified by letter). The pull direction is identified as A-axial or I-inclined. The angle of load and anchor inclination to the horizontal are identified by $\alpha_{1}$ and $\alpha_{2}$, respectively. The "depth" Identified is the vertical depth from the ground surface to the anchor tip. To get the depth of a helix plate the distance from the tip to the center of the helix ( 3 in for most anchors tested) must be subtracted (see figure 1.2). The loading is identified as SM-static monotonic and SUR-static with unloading and reloading cycles (cyclic loading tests are identified separately). The soil condition is identified as M(natural moisture content) $W$-wet or S-submerged. Subsequently, the soil test probe reading - STP and the installation torque- $\mathrm{T}_{1}$ are identified.

Figure 4.1 shows a typical plot of a load-displacement curve for an anchor pulled vertically and installed vertically on site C (clay). The data points recorded for the monotonic tests with reloading cycles are shown in figure 4.1 and explained hereafter. Note that most "monotonic" tests contained 2 cycles of unloading and re-loading at each $1 \mathrm{kip}$ increment of load and 1 cycle of unloading and re-loating near the point of maximum load $\left(Q_{u}\right)$. The following data points are recorded:

$P_{2 v}$ is the anchor load at 2 in vertical displacement; ( $P_{4 h}$, the anchor load at 4 in horizontal displacement is used for anchors installed vertically and pulled at an angle). For anchors installed at an angle to the vertical and pulled axially, the loads recorded under $P_{2 v}$ and $P_{4 h}$ are the loads for the 2 in vertical and 4 in horizontal displacement components, respectively. In some instances these 2 and 4 in displacements include residual displacements from unloading and reloading cycles.

$Q_{u}$ is the "ultimate" load (the maximum load attained by the anchor during pullout).

$\Delta_{\mathrm{u}}$ is the displacement at ultimate load measured in the direction of the initial pull. For anchors installed vertically and pulled at an angle $\alpha_{1}$ to the horizontal, the horizontal displacement component, $\Delta_{u h}$, can be approximately calculated by the equation $\Delta_{u h}=\Delta_{u} / \cos \alpha_{1}$, since for these anchors the anchor head displacement iended to be horizontal with only a minor vertical component. For anchors pulled axially or near axially $\Delta_{u}$ is an axial displacement. For the few anchors, where the pull was in a 


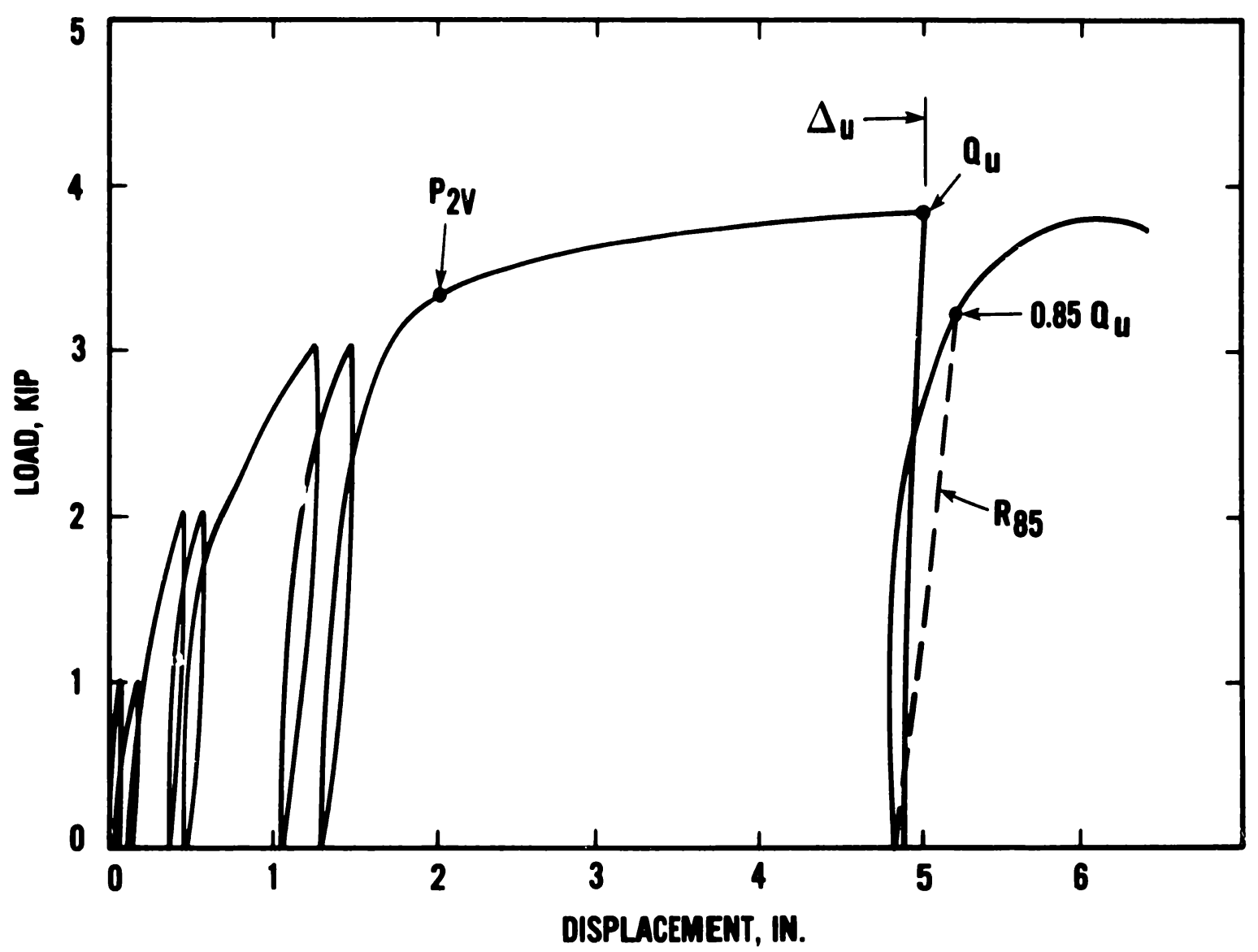

Figure 4.1 Plot of test C-7, vertical 6-1n single helix anchor, vertical pull 25 
direction normal to the shaft, $\Delta_{u}$ is the displacement in the direction of the pull.

$\mathrm{R}_{85}$ is the secant re-loading modulus at 85 percent of the load before unloading, measured at the highest load at which unloading and re-loading was performed (not necessarily $Q_{u}$ as in figure 4.2) expressed as a ratio of load to displacement $(1 \mathrm{~b} / \mathrm{in})$.

The results of the cyclic tests are given in tables B.2, B.4 and B.6. The symbols for the data shown in the cyclic tests are explained hereafter:

$P_{c} / Q_{u}$ is the ratio of the cyclic load to the estimated ultimate load obtained from monotonic tests in an adjacent location

$\mathrm{N}$ is the number of load cycles used

$P_{p} / Q_{u}$ is the ratio of preload (if any) to the estimated ultimate load $\Delta_{1}, \Delta_{10}, \Delta_{100}$, and $\Delta_{u}$ are the total displacements in the first, tenth, hundredth and last load cycle. (They are the sum of the displacement caused by the applied load in the last load cycle and the cumulative residual displacements from all previous load cycles.)

$\mathrm{R}_{10}$ is the secant re-loading modulus in the 10 th load cycle

$Q_{u}^{\prime}$ is the ultimate load actually obtained when the anchor was pulled out after completion of the cyclic loading.

\subsection{EFFECT OF LOADING RATE}

The effect of the loading rate on the characteristics of the load-displacement curve was investigated early in the test program in order to decide on the loading rate to be used in the tests. The fastest rate at which load could be applied in the monotonic tests was limited by the pumping capacity of the manually operated hydraulic system and in each case also depended on the ram displacement associated with a particular load increment. On the average, the fastest initial loading rate was approximately 4,000 $1 \mathrm{~b}$. per minute. This rate has a tendency to decrease as the ultimate load is approached. Thus it was not possible to investigate dynamic load effects.

The solid curve in figure 4.2 is the record of a test in which load increments were applied at a fast rate, and after each load increment the load was held until no measurable creep was recorded over a 15-minute period. For the load increments up to $4.25 \mathrm{kip}$, creep virtually ceased after 5 minutes. In the last two load increments creep continued for 20 minutes.

The shaded area in figure 4.2 is the estimated range of creep effects that could be anticlpated. The upper bound of this range represents the most rapid load application possible with the avallable equipment, and the lower bound a 


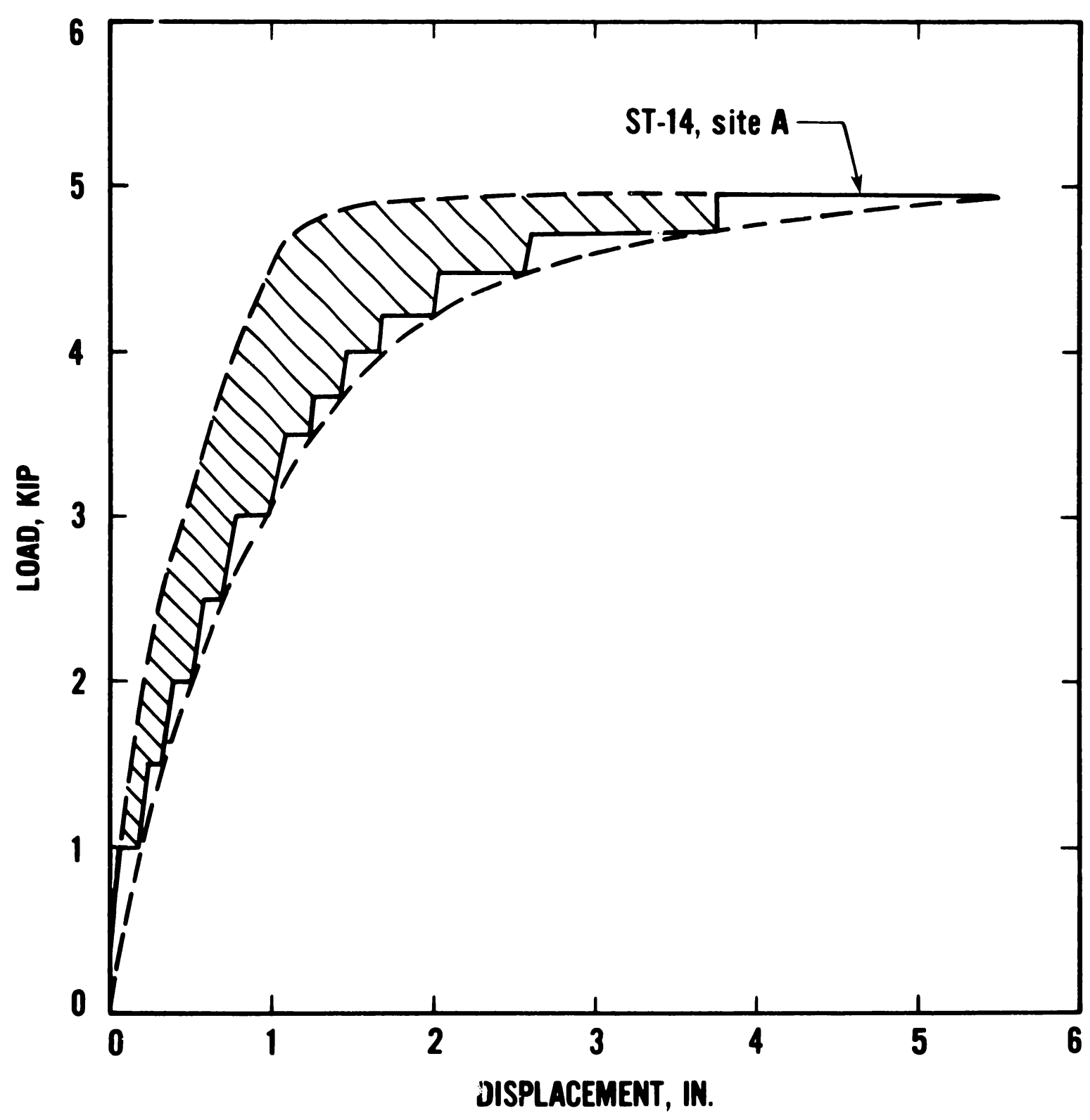

Figure 4.2 Effect of loading rate on load-displacement characteristics 
load-displacement relationship that would not be altered by further decreasing the loading rates iexcept that further creep would probably occur if a load increment would be held for a very long period of time, such as several days). On the basis of this, and several other observations, the load in the monotonic tests was applied at a rate of $600 \mathrm{lb} / \mathrm{minute.} \mathrm{While} \mathrm{this} \mathrm{loading} \mathrm{rate} \mathrm{would}$ not produce the lower-bound curve in figure 4.2 , the test results are assumed to be close to the lower-bound curve.

Cyclic loads were applied at a much faster rate, since these were intended to simulate windloads. However, the 30 second rise time for the load was much slower than the typical windload. The loading rate was limited by the capacity of the oil pump.

\subsection{STATIC LOAD-DISPLACEMENT CHARACTERISTICS OF 6-in SINGLE HELIX ANCHORS}

\subsubsection{Monotonic Tests}

Figure 4.3 shows the result of a typical monotonic loading test on a 6-in single helix anchor on Site $A(s i l t)$. The test is a vertical pullout test which was carried to full withdrawal. Vertical displacements of the anchor head in inches are plotted against applied load in $\mathrm{kip}$. Note that the initial portion of the load displacement curve is rather steep and there is a break at point A, at a load of about $1.1 \mathrm{kip}$. This break was characteristic of many, though not all the tests. There is a gradual, but not very drastic decrease in stiffness unt 11 the anchor yields at a load of approximately $4.8 \mathrm{kip}$. The anchor subsequently maintained j.ts load resistance during an additional 10 in withdrawal, and a reduced load resistance over an even larger range of displacements which is not recorded. Ductile behavior was characteristic of soll anchors tested on Sites $A$ and $C$ (silt and clay), even though the range of displacements over which the load is maintained varied with the soil type.

\subsubsection{Unloading and Reloading Cycles}

Figure 4.4 shows a vertical pullout test on a 6-in single helix anchor in sand (Site B) installed vertically to its full 4-foot depth. Two cycles of unloading and re-loading were conducted at $1 \mathrm{klp}$ intervals in order to assess the characteristics of pre-loaded anchors. The re-loading curves are generally much steeper than the inttial "virgin" loading curve, indicating substantial strain-hardening effects. The characteristics of the curve are interpreted as follows: Whenever load is applied, the soil is compacted, and up to the applied load, its load-displacement characteristics are modified. As soon as the applied load exceeds the pre-load, the load-displacement curve follows the shape of the virgin curve which would be obtained in monotonic loading except that some displacement of the curve will have occurred as a result of the unloading and reloading cycles. The initial break in the virgin curve, Fhich was observed at point " $A$ " on figure 4.3, can probably be attributed to preconsolidation of the soil which was abour equivalent to a $1.1 \mathrm{kip}$ anchor pull. 


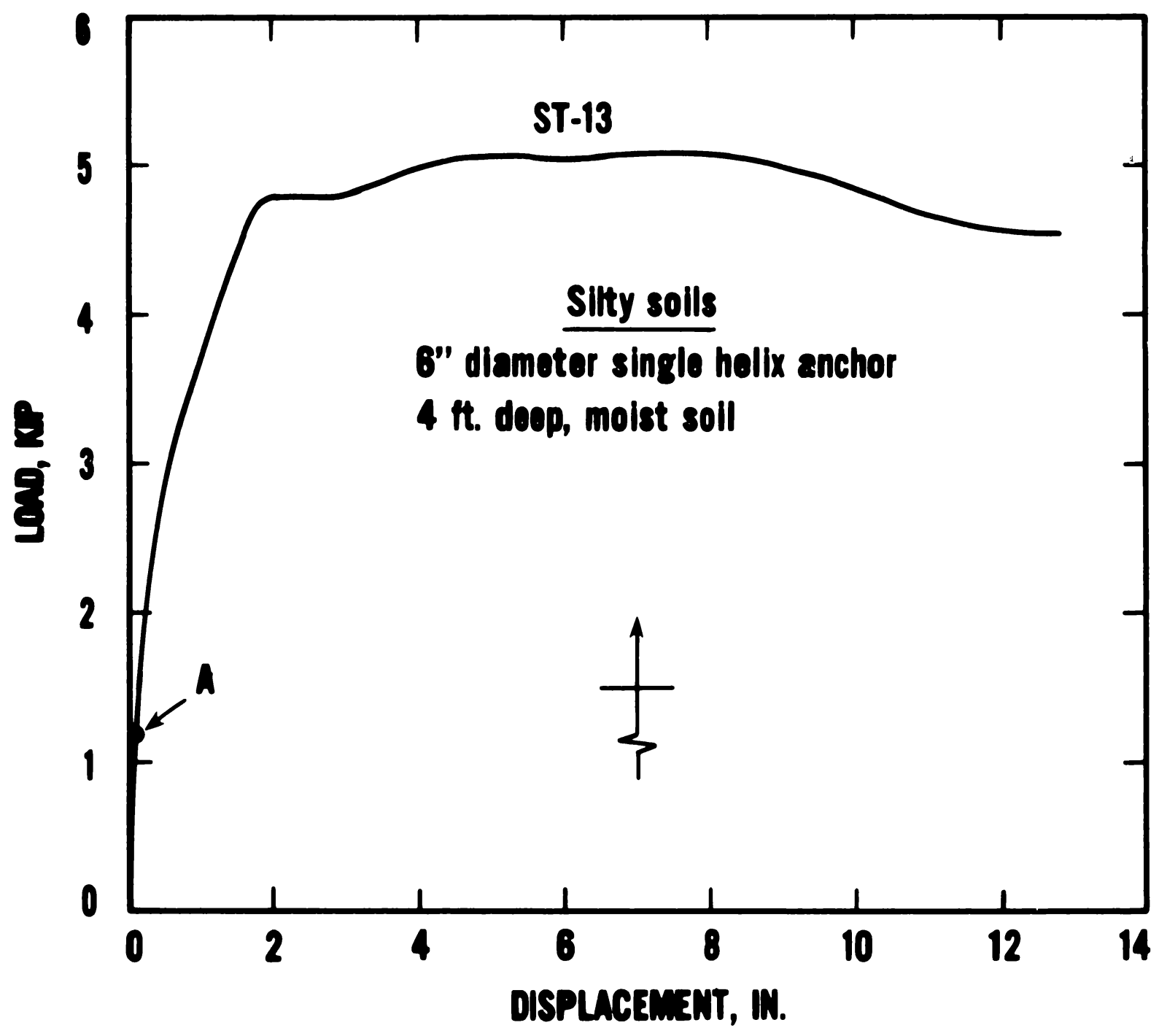

Figure 4.3 Monotonic loading test in silt 


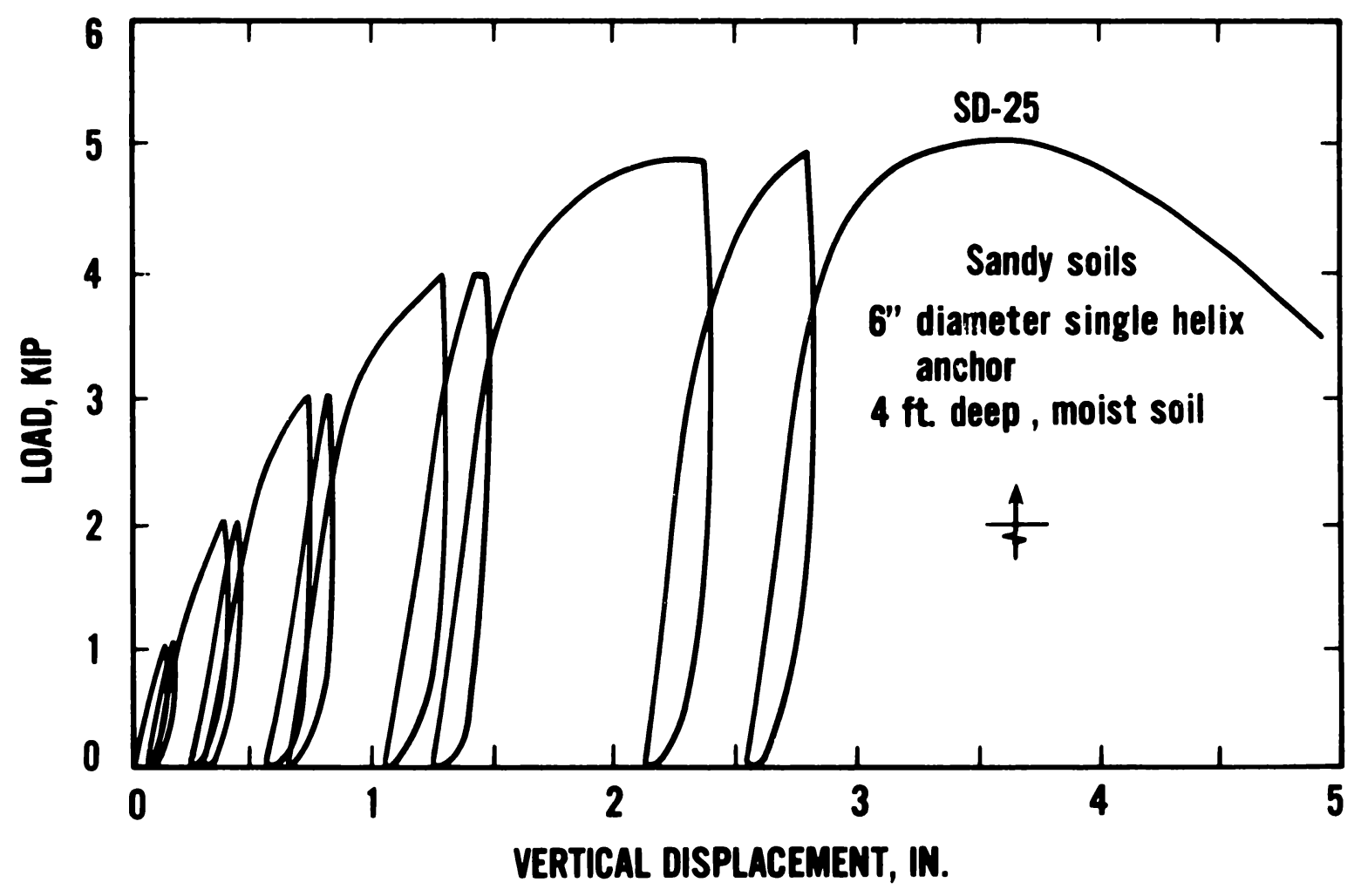

Figure 4.4 Pullout test with unloading and reloading cycles in sand 


\subsubsection{Anchors Installed at an Angle and Pulled Coaxially}

Figure 4.5 shows the load-displacement curve for an approximately coaxial pull on an anchor which was installed on Site $B$ (sand) at an angle of $45^{\circ}$ to the horizontal. Note that this curve is similar to the one shown in figure 4.4 , except that the load capacity is much lower because of the reduced anchor depth due to the $45^{\circ}$ installation angle. The break in the virgin curve is very pronounced and occurs at about $0.5 \mathrm{kip}$.

\subsubsection{Anchors Installed Vertically and Pulled at an Angle}

Figure 4.6 shows the load-displacement curve for a vertically installed anchor on Site B, pulled at an angle of $40^{\circ}$ to the horizontal. The initial stiffness of this anchor is very low (only $1.2 \mathrm{kip}$ capacity at a 4-inch displacement), since the 5/8-1nch thick shaft developes very little lateral soll resistance as it is pulled horizontally into the soil. However, as the shaft is bent in the direction of the pull the soil resistance increases and the ultimate pullout resistance exceeds that for a vertical pull. The initial, flatter slope of the re-loading curves is attributable to the elastic rebound of the anchor shaft which occurs before the soll resistance is engaged. Otherwise the re-loading curves show characteristics similar to those in the previously discussed

tests. The anchor deformation in these tests is 1llustrated in figure 4.7 which shows a 4-in double helix anchor which was exposed by excavation after completion of a similar test.

\subsubsection{Effects of Loading Configuration}

The reconstructed virgin curves for the tests shown in figures 4.4 through 4.6 which are for tests performed in similar soll conditions, are plotted in figure 4.8. When these envelope curves were drawn, displacement caused by the unloadIng and re-loading cycles were estimated and subtracted from the total displacement. The figure 1llustrates the difference in the performance characteristics. Note the large displacement required to develop load resistance in a vertically Installed anchor subjected to diagonal load, the most commonly encountered situation associated with present mobile home anchoring technology.

The load capacity (ultimate load) of the coaxially pulled inclined anchor (test SD 29) was about 50 percent of the load capacity developed in test SD 25. Anchor SD 25 was installed at a depth of $4 \mathrm{ft}$ and anchor SD 29, because of 1 ts Inclination, at a depth of $2.8 \mathrm{ft}$. Thus a 30 percent increase in embedment depth caused a 50 percent increase in load capacity. Anchor SD 30 developed a higher load capacity than anchor SD 25, however a much larger displacement occurred before the full load capacity was developed. Much of this displacement is attributable to the bending of the anchor shaft (see figure 4.7). The load capacity of anchor SD 30 was $6 \mathrm{kip}$ and that of SD 29 was $5 \mathrm{kIp}$. Thus load capacity increased by 20 percent. This $c$ rend was consistently observed, regardless of soll conditions. The trend is further illustrated in figure 4.9, which shows a comparative plot of tests on vertically installed anchors performed at different load inclinations. These tests were performed on Site A (silty 


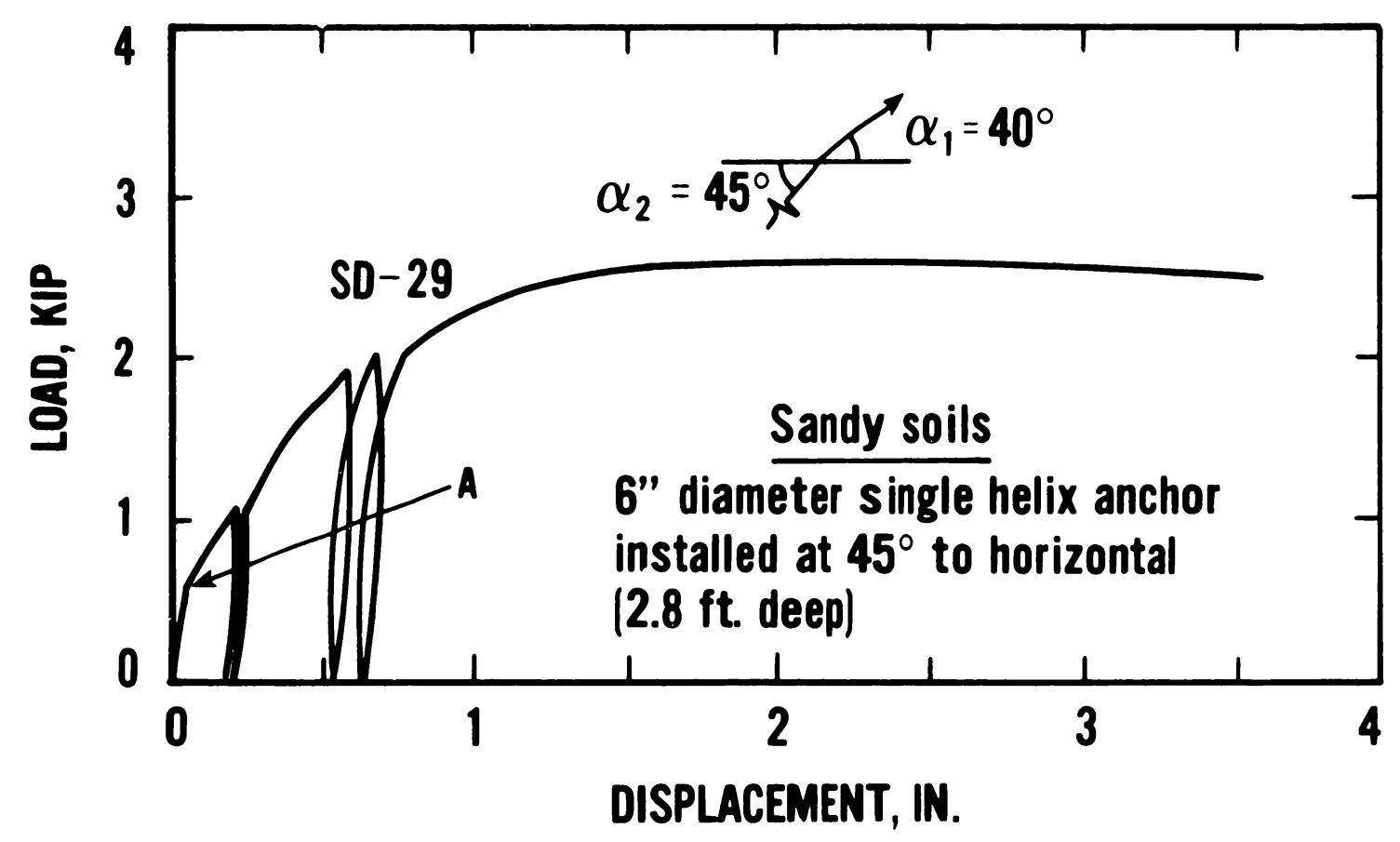

Figure 4.5 Coaxial pullout test on inclined 6-in single helix anchor in sand 


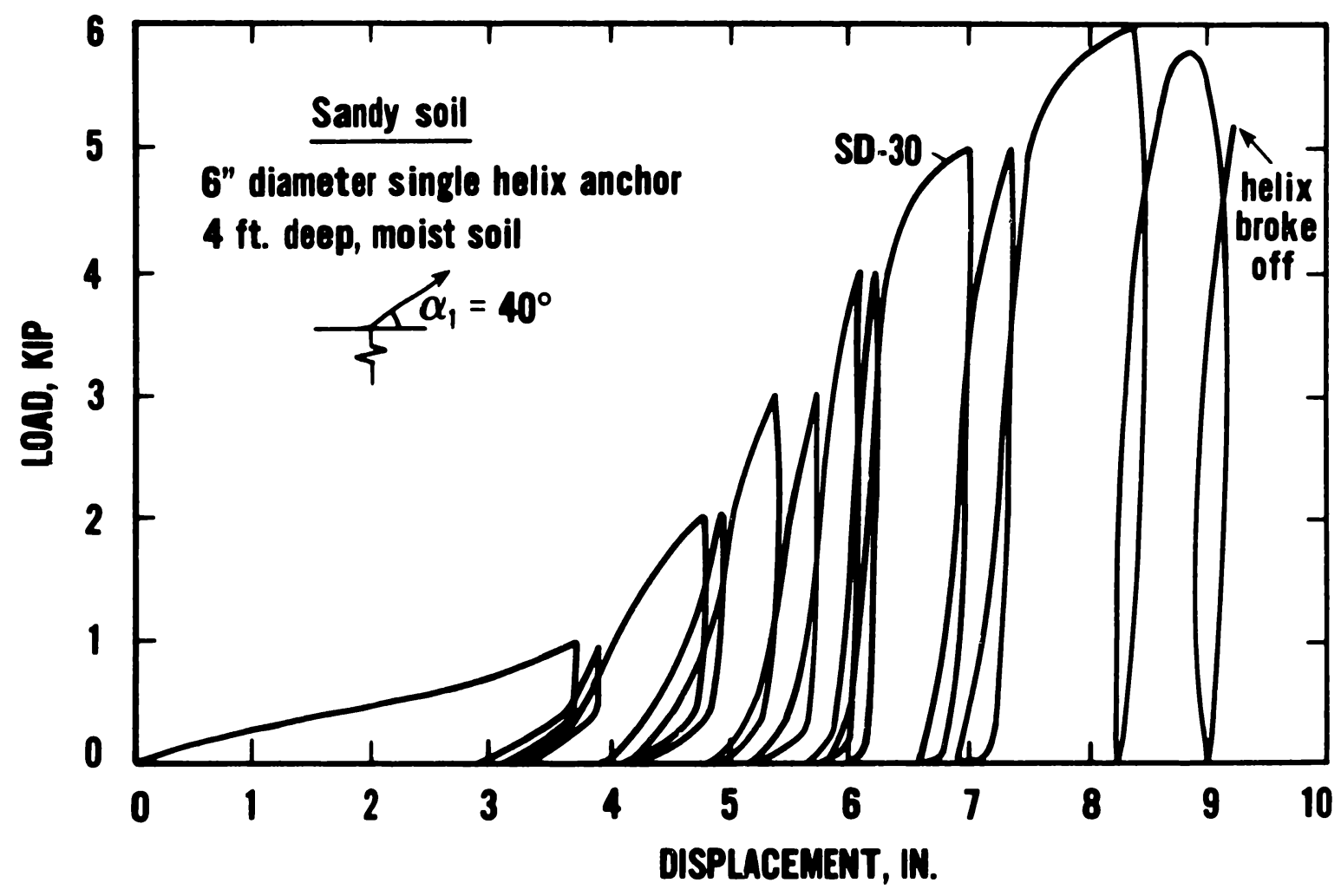

Figure 4.6 Inclined pullout test on a vertically installed 6-in single helix anchor in sand 


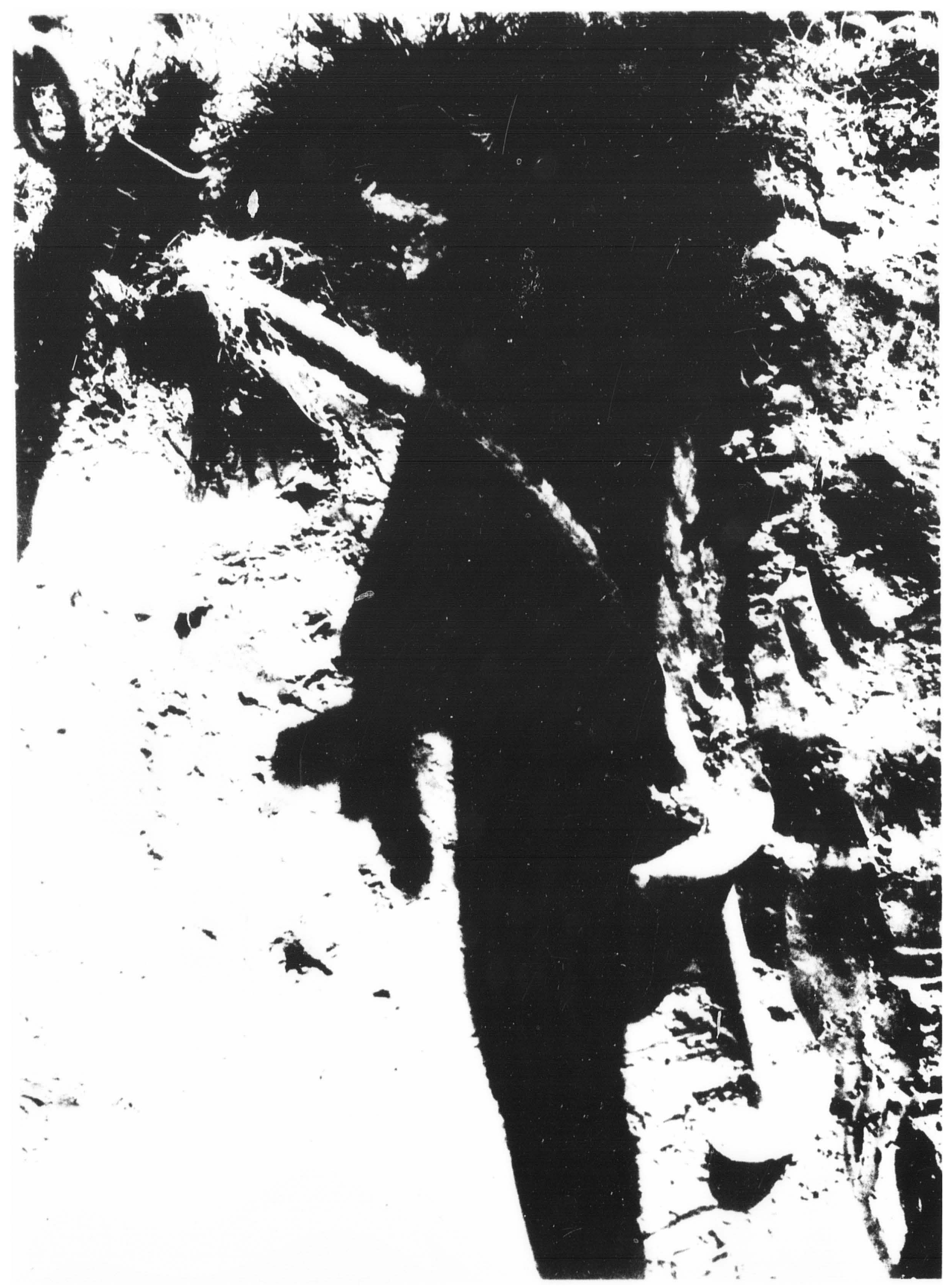

Figure 4.7 Anchor deformation in inclined test on vertically installed 4-in double hel $\mathrm{jx}$ anchor 


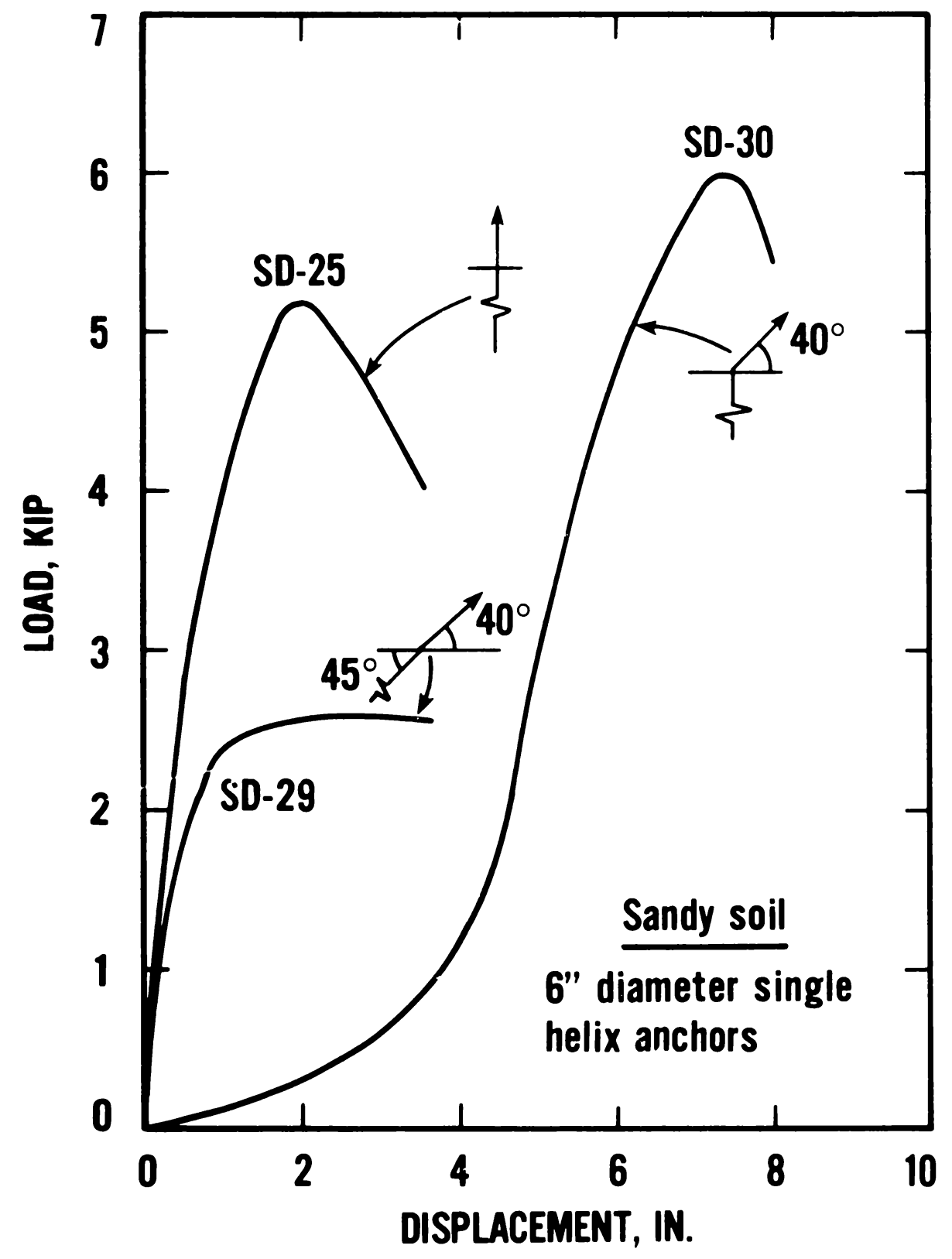

Figure 4.8 Effect of loading configuration on load-displacement characteristics of anchors 


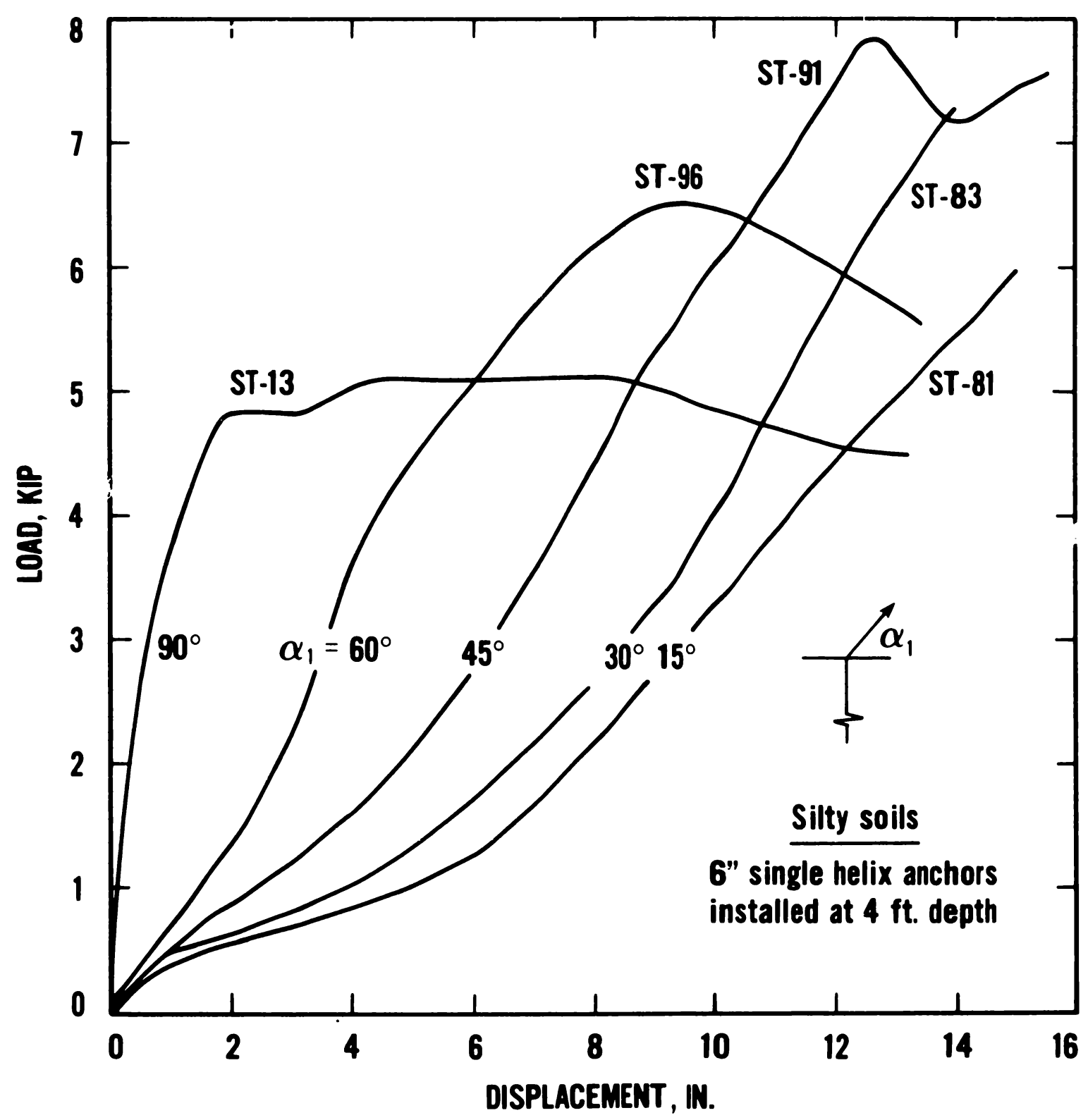

Figure 4.9 Effect of load inclination on the load-displacement characteristics of vertically installed anchors 
soils). Note that as angle $\alpha_{1}$ decreases from $90^{\circ}$ to $15^{\circ}$, the load-deflection slope (stiffness) of the virgin load-displacement curve decreases, but the load capacity of the anchor increases (at the flatter angles the full load capacity could not be realized because of fallure of the anchor hardware). It is interesting to note that while the virgin load-displacement curves show great differences in stiffness, the re-loading characteristics are quite similar for the various load inclinations and resemble those illustrated in figure 4.6. This is shown in table 4.1 .

Table $4.1 \begin{gathered}\text { Reloading Moduli }\left(\mathrm{R}_{85}\right) \text { for th } \\
\text { Shown in Figure } 4.9\end{gathered}$
\begin{tabular}{ccc} 
Test Specimen & $\alpha_{1}{ }^{\circ}$ & $\mathrm{R}_{85,1 \mathrm{~b} / \mathrm{in}}$ \\
\hline ST 13 & 90 & - \\
ST 96 & 60 & 3980 \\
ST 91 & 45 & 3610 \\
ST 83 & 30 & 5020 \\
ST 81 & 15 & 3500
\end{tabular}

There is no re-loading curve for test ST 13 since the importance of the re-loading characteristics was only realized at a later stage in the test program. However, data from test ST 122 , a vertical pull-out test conducted at the same site, indicate a re-loading modulus of $17,0001 \mathrm{~b} / \mathrm{in}$.

Note from figure 4.6 that the re-loading curves can be divided into two segments. Initially, there is a displacement of the order of about $1 / 2$ in where the reloading curve is relatively flat. This part of the re-loading curve is attributable to the bending of the anchor shaft which rebounds elastically when it is unloaded. Subsequently, the re-loading curves are very steep with moduli similar to the one observed for test ST 122 (see above). The two segments of the re-loading curve are combined when $R_{85}$ is determined. It is important to note that the re-loading moduli observed in the inclined tests of verticallyinstalled anchors far exceed those that would be required to satisfy present standards and regulations $[2,17]$.

Another loading configuration that was tested on the silty site is non-coaxial loading on inclined anchors $\left(\alpha_{2}=135^{\circ}, \alpha_{1}=15^{\circ}, 45^{\circ}\right.$ and $60^{\circ}$ - see sketch in figure 4.10). Similar configurations occur in practice, since it is difficult to insert vertical soil anchors under the outer walls of an installed mobile home. Typical test results are shown in figure 4.10. Because of the large displacements associated with this loading configuration the displacement scale is compressed. Note that, as in the case of vertical anchors with inclined loading, the stiffness of the anchor decreases as the angle of the load with the horizontal decreases. Test ST 91 was plotted in figure 4.10 for comparison. Note that the performance of anchors ST 102, 105 and 108 is very poor when compared with vertical anchors with inclined loading, which also experience considerable displacements before developing their load capacity. It is obvious 


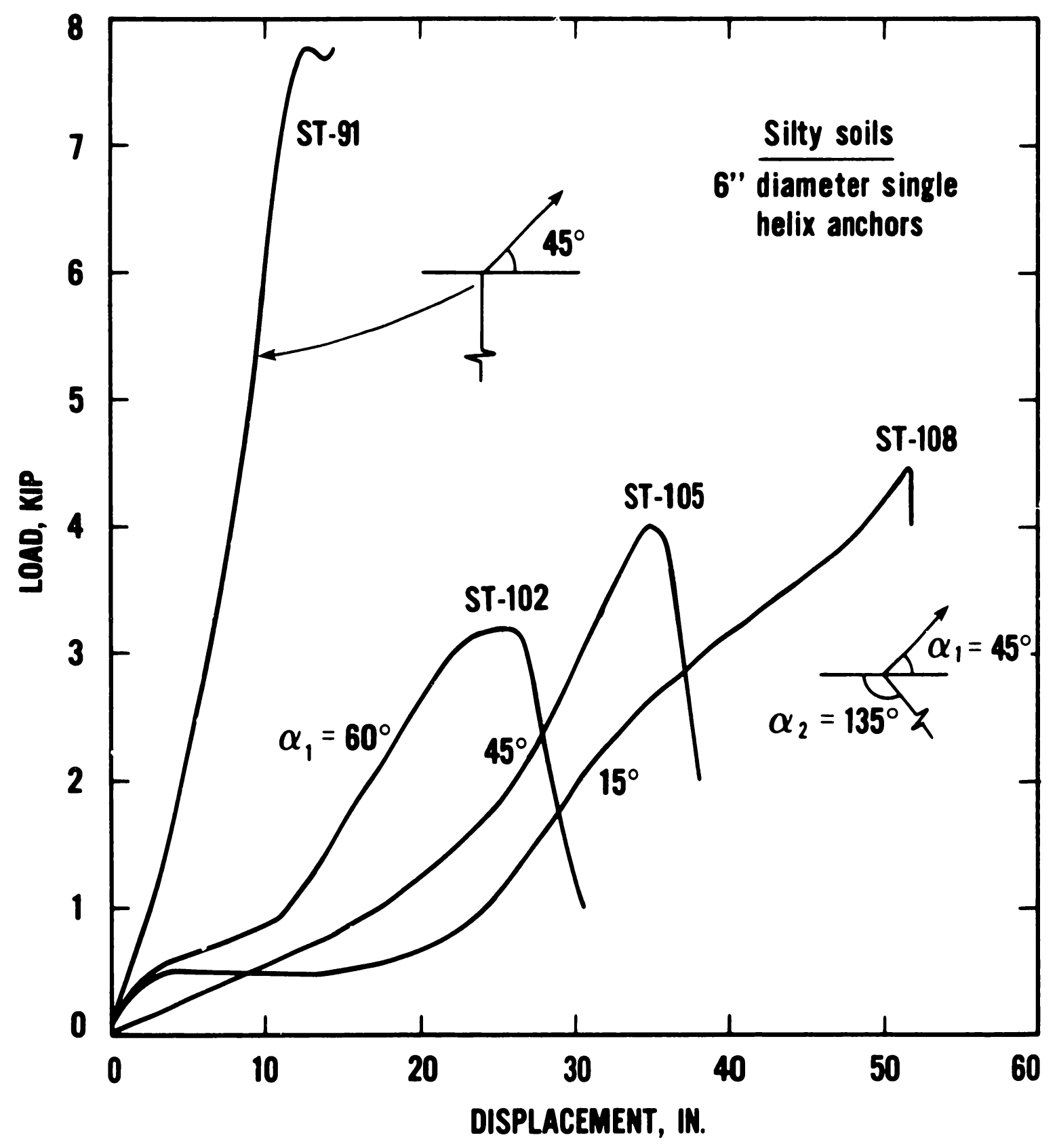

Figure 4.10 Load-displacement characteristics of inclined anchors subjected to non-coaxial loads on the silty site. 
from the test results that this is the least desirable loading configuration tested. Thus if anchors are tilted away from the mobile home during Installation their stiffness and load capacity are likely to decrease.

4.3.6 Effects of Inclination and Depth on the Load Capacity of Coaxially Loaded Anchors

The effect of the angle of load and anchor inclination on coaxially loaded inclined anchors is illustrated in figure 4.11. As expected, the load capacity decreases as the angle of anchor installation becomes flatter. Anchor capacity in this case may be influenced by two opposing effects: As the installation angle becomes flatter, the depth of the anchor decreases since the embedment length of approximately $4 \mathrm{ft}$ remains the same. On the other hand, some test results and load capacity hypotheses [14,11] indicate that, for a given depth, anchor capacity increases as the installation angle becomes flatter. However, these observations are not corroborated by other investigators. For instance Harvey and Burley [10] found that coaxial pull-out capacity for shallow anchors in sand for the same depth of embedment is approximately the same for vertically installed and inclined anchors. The test results obtained in this project provide some information that can be compared with the above discussed data. Figure 4.12 shows the results of pull-out tests of anchors installed at various depths on Site A. Note that there was no significant difference between the anchors installed at 3 and $4 \mathrm{ft}$ depths. This is an indication that anchors deeper than $3 \mathrm{ft}$ experienced local fallure (the fallure surface did not extend to the ground surface). The depth to diameter (D/B) ratio for the $3 \mathrm{ft}$ deep anchors is 5.5 and that for the $4 \mathrm{ft}$ deep anchors is 7.5 , and the observation that the $3 \mathrm{ft}$ deep anchors acted like deep anchors would be in agreement with data obtained by others $[8,12]$.

Two interesting observations can be made from the comparative plots in figure 4.12: 1. As the anchors become shallower, their peak capacity is reached at an increasingly smaller displacement and their "ductility" decreases. This is probably related to the fallure surface developing as the anchor is withdrawn. 2. The load capacity of an anchor, embedded at a given depth is not unique and depends on the original embedment depth. Thus the anchor which was initially embedded $3 \mathrm{ft}$ resisted more than $4.5 \mathrm{kip}$ after it was withdrawn 13 inches and was $1 \mathrm{ft} 11 \mathrm{in}$ deep. At the same depth the initially 2-ft deep anchor resisted only a $3 \mathrm{kip}$ load. This phenomenon can be explained by the development of a inique fallure surface for each anchor depth, which is associated with the virgin load-deflection curve. The soll mass within this surface is compacted by the applied load. This compaction accounts for the strain hardening effect evident in the re-loading curves. When the anchor is pulled out to a shallower depth the compacted soil mass within the silp surface moves up with it, and the shape of the slip surface does not substantially change.

Figure 4.13 shows a comparison between the pullout strengths of co-axially loaded vertical and coaxially loaded inclined anchors for various installation depths. For the $1 \mathrm{ft}$ depth the inclined anchor had substantially higher strength than the vertical anchor. However, for the other depths the results 


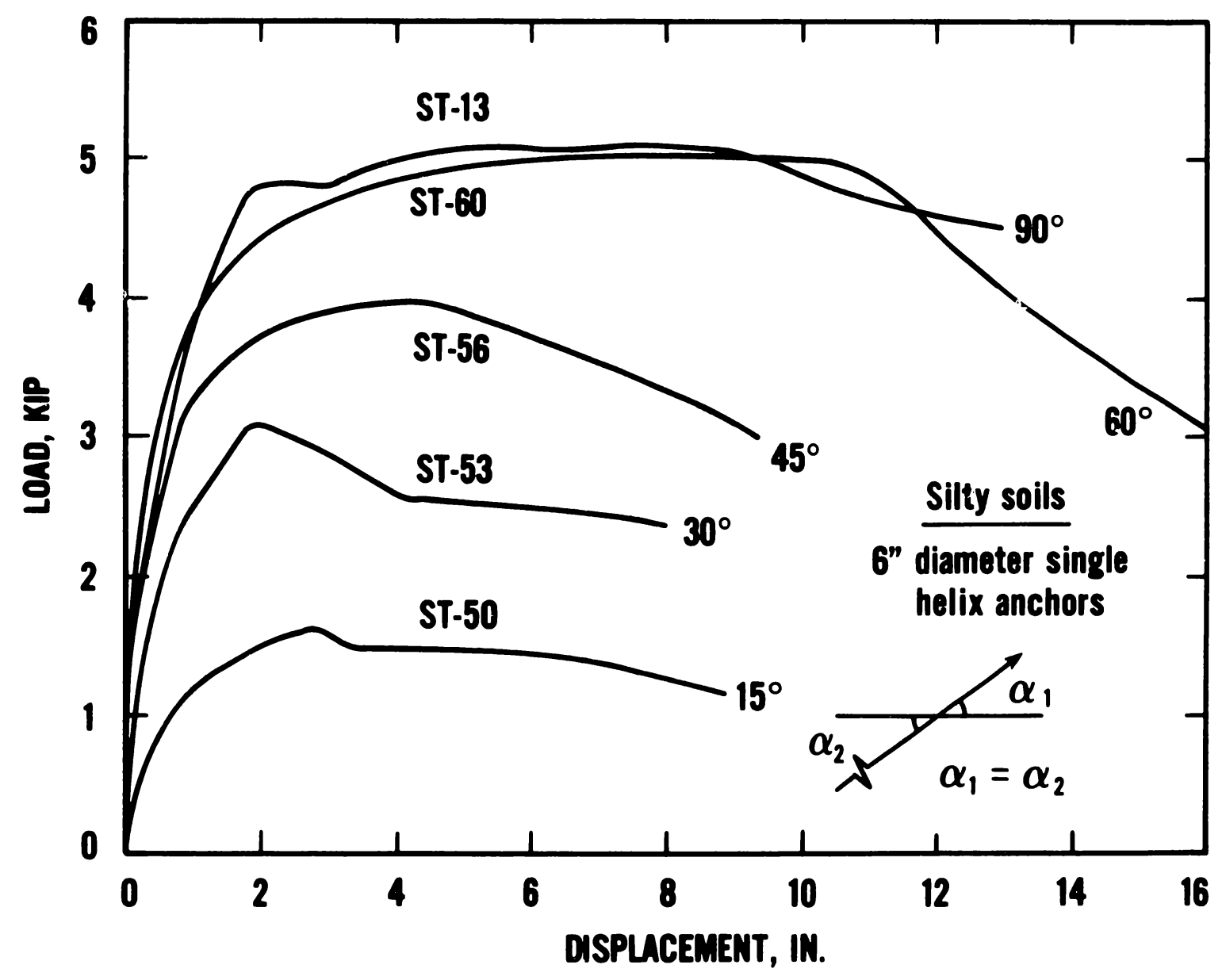

Figure 4.11 Load-deflection curves for coaxially loaded 6-in single helix anchors installed at various angles 


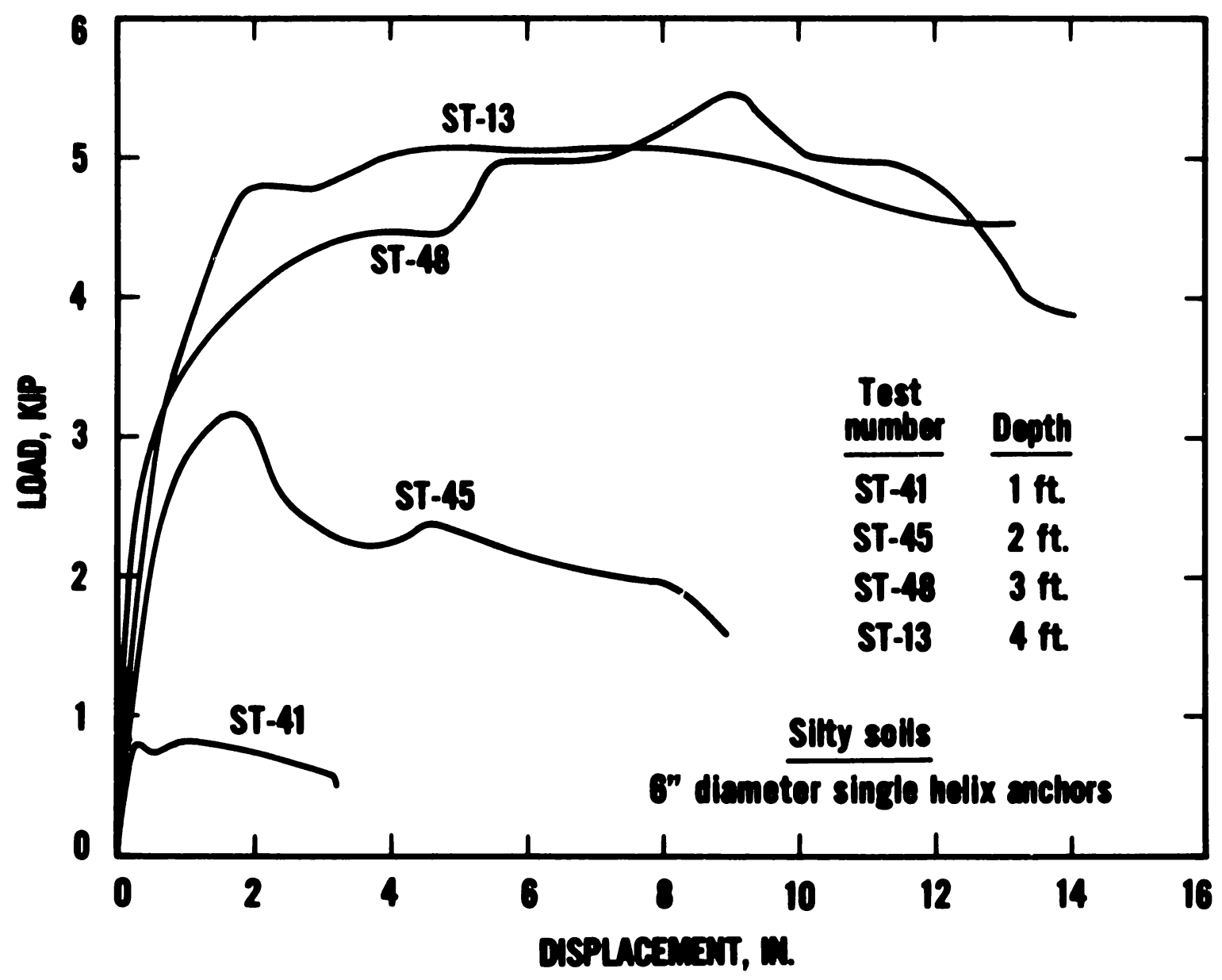

Figure 4.12 Effects of embedment depth on the load capacity of vertically installed 6-in single helix anchors subjected to coaxial load 


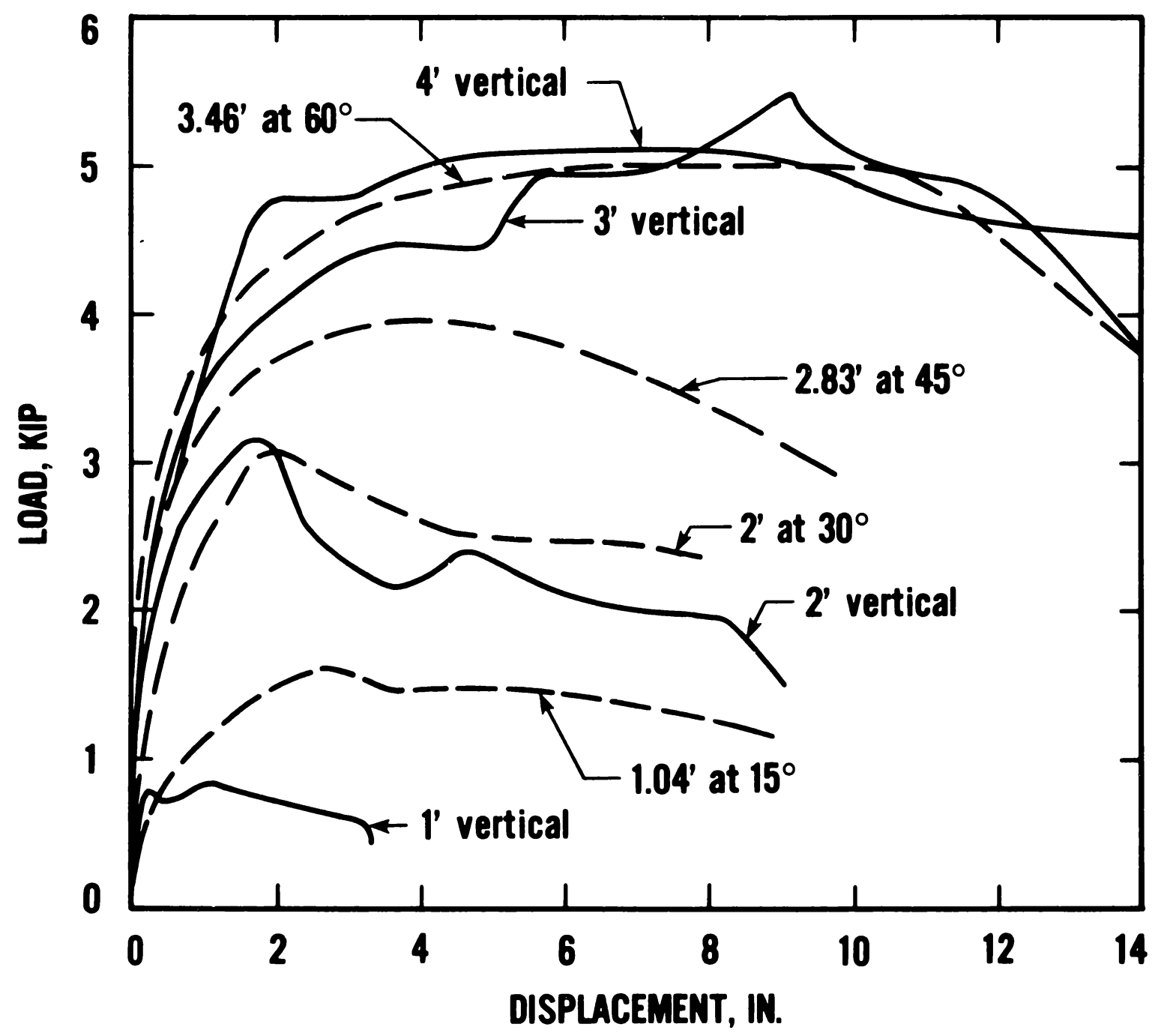

Figure 4.13 Comparison between inclined and vertical coaxially pulled 6-in single helix anchors 
of the inclined-anchor tests fall into the same pattern as those of the vertical-anchor tests when anchor depth is correlated with load capacity, and there is no evidence that the load capaity of inclined anchors is greater than that of vertical anchors installed at the same depth. To ascertain whether the test results are significant, all the test results are tabulated in table 4.2.

Table 4.2 Comparison of the Strength of Coaxially Loaded Anchors Installed at Various Depths

Test No. Depth, ft Inclination $\alpha_{2} \quad Q_{u}, 1 b \quad Q_{u, 1 b} \quad v$

$\begin{array}{lllrrr}\text { ST } 40 & 1 & 90^{\circ} \text { (vertical) } & 700 & & \\ \text { ST } 41 & 1 & 90^{\circ} & 800 & 840 & 0.19 \\ \text { ST } 42 & 1 & 90^{\circ} & 1020 & & \end{array}$

\begin{tabular}{|c|c|c|c|c|c|}
\hline $\begin{array}{ll}\text { ST } & 49 \\
\text { ST } & 50 \\
\text { ST } & 51\end{array}$ & $\begin{array}{l}1.02 \\
1.02 \\
1.02\end{array}$ & $\begin{array}{l}15^{\circ} \\
15^{\circ} \\
15^{\circ}\end{array}$ & $\begin{array}{l}1280 \\
1610 \\
1450\end{array}$ & 1447 & 0.11 \\
\hline $\begin{array}{ll}\text { ST } & 43 \\
\text { ST } & 44 \\
\text { ST } & 45\end{array}$ & $\begin{array}{l}2 \\
2 \\
2\end{array}$ & $\begin{array}{l}90^{\circ} \\
90^{\circ} \\
90^{\circ}\end{array}$ & $\begin{array}{l}3120 \\
3300 \\
3180\end{array}$ & 3200 & 0.03 \\
\hline $\begin{array}{ll}\text { ST } & 52 \\
\text { ST } & 53 \\
\text { ST } & 54\end{array}$ & $\begin{array}{l}2 \\
2 \\
2\end{array}$ & $\begin{array}{l}30^{\circ} \\
30^{\circ} \\
30^{\circ}\end{array}$ & $\begin{array}{l}3420 \\
3120 \\
2090\end{array}$ & 2880 & 0.24 \\
\hline $\begin{array}{ll}\text { ST } & 55 \\
\text { ST } & 56 \\
\text { ST } & 57\end{array}$ & $\begin{array}{l}2.83 \\
2.83 \\
2.83\end{array}$ & $\begin{array}{l}45^{\circ} \\
45^{\circ} \\
45^{\circ}\end{array}$ & $\begin{array}{l}4220 \\
4000 \\
4520\end{array}$ & 4247 & 0.06 \\
\hline $\begin{array}{ll}\text { ST } & 46 \\
\text { ST } & 47 \\
\text { ST } & 48\end{array}$ & $\begin{array}{l}3 \\
3 \\
3\end{array}$ & $\begin{array}{l}90^{\circ} \\
90^{\circ} \\
90^{\circ}\end{array}$ & $\begin{array}{l}5250 \\
5600 \\
4800\end{array}$ & 5217 & 0.08 \\
\hline $\begin{array}{ll}\text { ST } & 58 \\
\text { ST } & 59 \\
\text { ST } & 60\end{array}$ & $\begin{array}{l}3.46 \\
3.46 \\
3.46\end{array}$ & $\begin{array}{l}60^{\circ} \\
60^{\circ} \\
60^{\circ}\end{array}$ & $\begin{array}{l}5280 \\
4300 \\
4110\end{array}$ & 4563 & 0.14 \\
\hline
\end{tabular}

$\bar{Q}_{u}=$ average load capacity, $1 \mathrm{~b}$

$v=$ coefficient of variation of the sample 
It can be seen from table 4.2 that with the exception of tests ST 54, ST 59 and ST 60 the trend is reasonably consistent. This leaves the question why the $15^{\circ}$ anchors have a consistently higher load capacity than the $1 \mathrm{ft}$ deep vertical anchors, while in all other instances the load capacity of inclined anchors was approximately equal to that of vertical anchors of the same depth. The explanation is probably in the fact that the pull exerted by the $15^{\circ}$ anchors is predominantly horizontal creating a failure surface the geometry of which differs substantially from that of the $1 \mathrm{ft}$ deep vertical anchor. The field notes indicate that the fallure of the $1 \mathrm{ft}$ deep vertical anchors created a 24 in diameter 8011 mound and that of the $15^{\circ}$ anchors a $22 \times 32$ in mound "along the axis of the anchor".

4.3.7 Comparison of Coaxially Loaded Inclined Anchors and Vertical Anchors Subjected to Inclined Loads

Anchors which have to resist inclined loads (containing a horizontal load component) are in present practice installed vertically. However, they could also be installed at an angle in order to resist the load in coaxial pull. The drastic difference between these two conditions was shown in figure 4.8. The general load-displacement characteristics of the virgin curves and the reloading curves have been previously discussed. The question arises how the great difference in load capacity (ultimate strength) between these two conditions can be explained. Part of the explanation is related to anchor depth. An anchor installed at an angle of $45^{\circ}$ will have only 70 percent of the full depth, while the vertical anchor is installed to its full depth. It has been previously shown for coaxially loaded anchors that except for very flat angles inclined anchors have about the same load capacity as vertical anchors of equal depth. On the other hand, vertical anchors subject to an inclined pull consistently developed higher load capacities than axially pulled vertical anchors of equal depth. It is belleved that the moment transmitted to the helix plate and the lateral pressure transmitted by the anchor shaft to the soll play a major part in this increased load capacity by subjecting the soll mass on the load side of the anchor to compression. The compressive load in turn will tend to Increase the shear strength of the soil mass on the load side of the anchor. An examination of figure 4.7 reveals evidence of the compression of the soil mass on the load side of the anchor.

\subsection{COMPAR ISON BETWEEN DIFFERENT ANCHOR TYPES}

\subsubsection{4-1n Double Helix Anchors}

Figure 4.14 shows a comparison between the load deflection curves for 6-in single helix and 4-in double helix anchors on the silty site. The broken lines are for 6-in single helix anchors and include coaxial tests on vertical and $45^{\circ}$ inclined anchors (ST 13 and ST 56) and a $45^{\circ}$ pull on a vertically installed anchor (ST 91). The tests on the 4-in double helix anchors are shown by the 8olid 11nes. Test ST 16 corresponds to test ST 13, ST 69 to ST 56 and ST 89 to ST 91. Two trends are obvious. The 6-in single helix anchors develop higher 


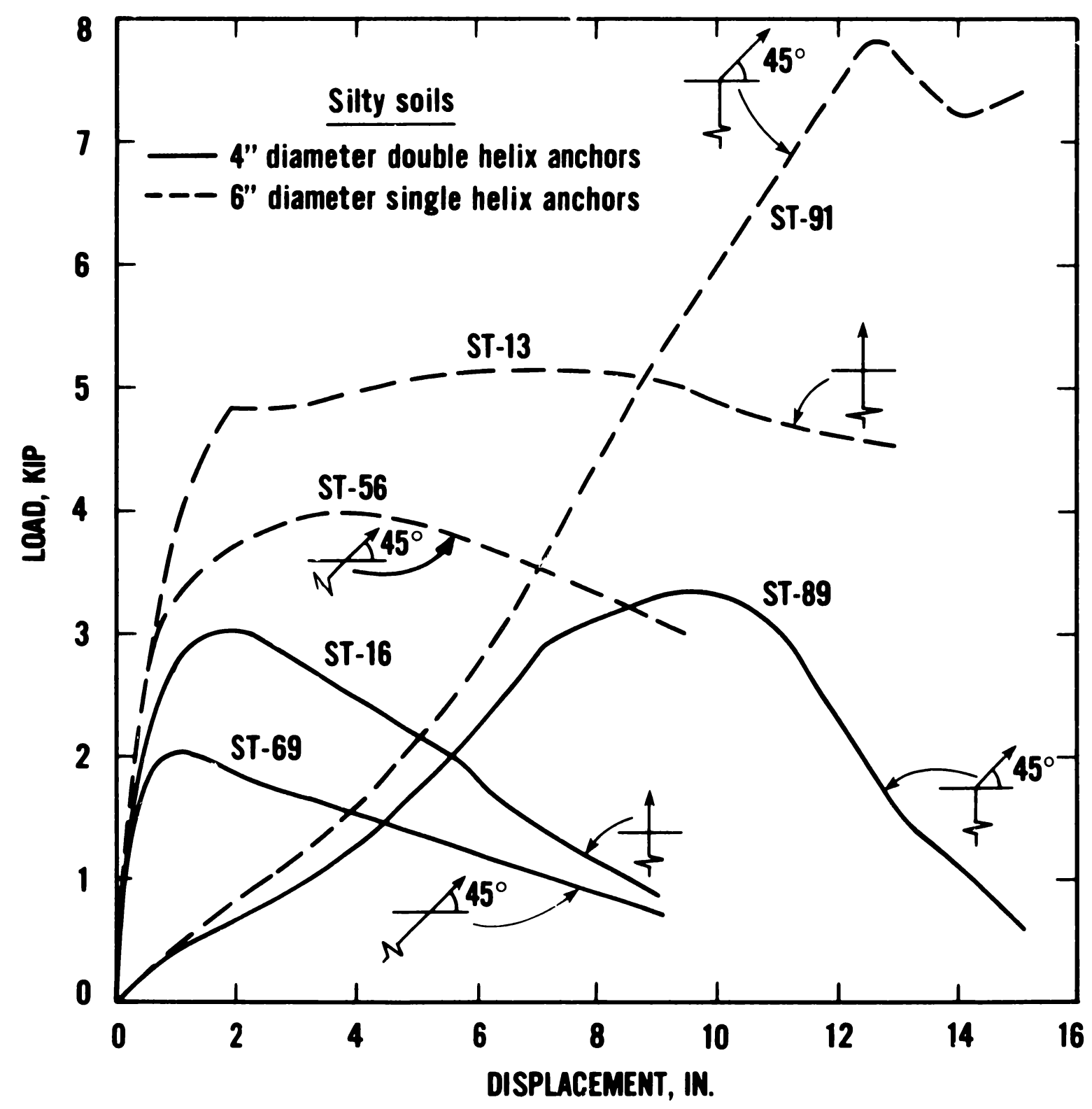

Figure 4.14. Comparison between the load-displacement characteristics of 6 -in single helix and 4-in double helix anchors 
load capacities and also tend to exhibit more ductility (except for test ST 91 which may have resulted in a hardware fallure).

Several factors combine to produce the difference in performance: 1 . The embedment depth of the helix of the 6-in single helix anchor is deeper $(3.7 \mathrm{ft}$ vs $2.6 \mathrm{ft}) ; 2$. The 6 -in single helix plate has a larger area $(2.25$ times the area) and 3. The 4-in double helix anchor has two helixes. Many authors claim that anchor capacity is proportional to the area of the anchor plate [12]. For the tests plotted on figure 4.14 the capacity ratios are 1.73 for coaxially pulled vertical anchors, 2 for coaxially pulled anchors inclined $45^{\circ}$ and 2.7 for vertical anchors pulled at $45^{\circ}$. This can be compared with the area ratio of 2.25. It should be noted that the correlation between the load capacities of the two anchor types is probably affected by all the factors mentioned above (areas of helix plate, anchor depth, and the presence of the second helix in the 4 in anchors).

Another aspect of anchor performance that can be compared are initial stiffness and ductility. Anchor ST 13 was very ductile, while its 4-in single helix counterpart, anchor ST 16 rapidly lost load capacity after the maximum load was attained. The most likely explanation for this difference is that the failure mechanism of anchor ST 13 made it a deep anchor (the slip surface did not extend to the ground surface) while anchor ST 16 acted as a shallow anchor. There was a considerable difference in stiffness between anchors ST 91 and ST 89, namely, the 6 in single helix anchor had smaller lateral displacement than the 4-in dovble helix anchor. This difference was consistenly observed in all the anchor tests and was noi anticipated, since it was thought that the long slender shaft of the 6 in single helix anchor would provide less resistance to lateral displacement.

In figure 4.15 load-displacement curves for vertical 4-1n double helix anchors pulled at various angles are compared with each other. The trend observed is similar to that shown in figure 4.9, namely, the stiffness decreases and the load capacity tends to increase as the angle of pull decreases from $90^{\circ}$ to $15^{\circ}$. As previously noted for the $45^{\circ}$ pull, the stiffness as well as the load capacity of the 4-in double helix anchors are smaller than those of the 6-in single helix anchors.

In figure 4.16 tests on coaxially loaded inclined 4-in double helix anchors, installed at various angles to the horizontal $\left(\alpha_{1}\right)$, are compared. This figure should be compared with figure 4.11 for 6-in single helix anchors. Note that in figure 4.11 the vertical anchor and the $60^{\circ}$ inclined anchor had similar load capacities. After comparison with pullout tests at various depths this phenomenon was taken as an indication that both of these anchors acted as deep anchors, and thus their load capacity did not significantly diminish with depth. In the case of the 4 in double helix anchors figure 4.16 gives a clear indication that all the anchors acted as shallow anchors. A tabulation of the depth ratio versus the load capacity ratio is given in table 4.3 , to show the average trend of the test results. The load capacity of most of the inclined anchors is roughly proportional to their depth. As in the case of the 6-in single helix 


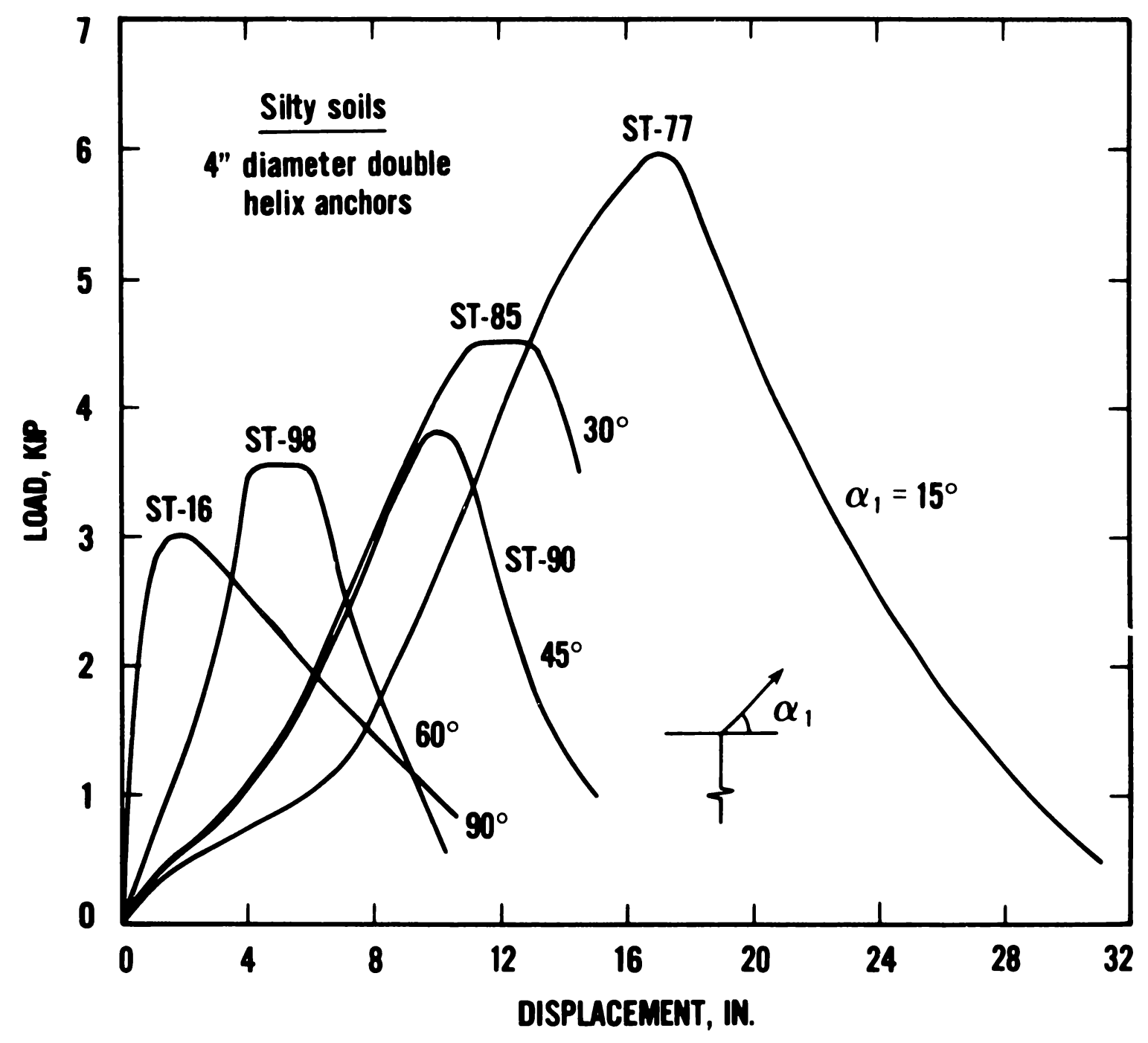

Figure 4.15. Comparison of load-displacement characteristics of vertically installed 4-in double helix anchors pulled at different angles 


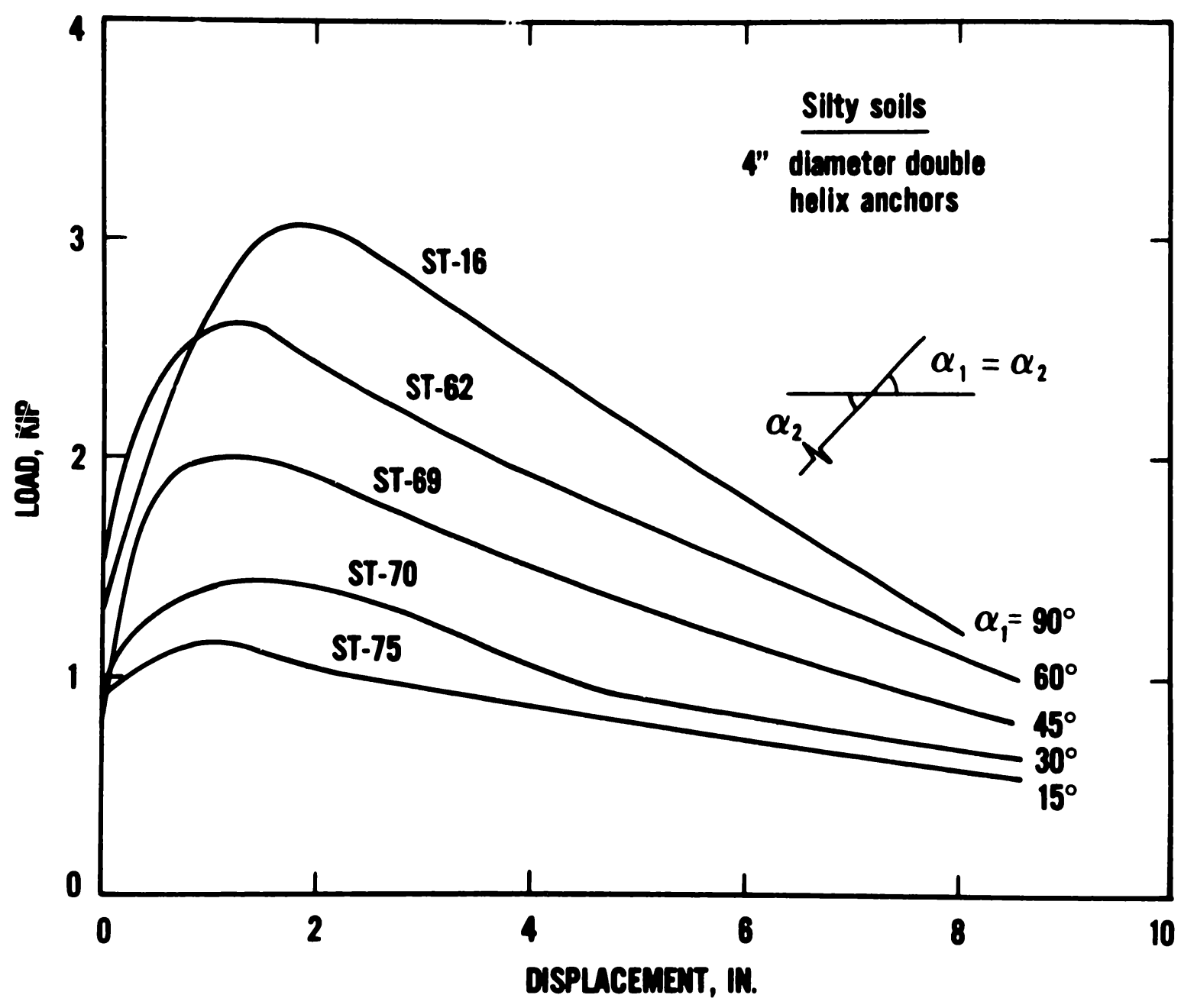

Figure 4.16. Comparison of load-displacement characteristics of coaxillay loaded 4-in double helix anchors installed at different angles 
anchors the load capacity of the $4-1$ in double hellx anchors at the $15^{\circ}$ inclination was higher than that predicted by the overall trend.

Table 4.3 Effect of Anchor Inclination on the Load Capacity of Coaxially Loaded 4-1n Double Helix Anchors in Silty Solls

$$
\begin{aligned}
& \begin{array}{llllll}
\alpha_{2} & \mathrm{n} & 0_{\mathrm{u}}, 1 \mathrm{~b} & \mathrm{v} & \mathrm{D} / \mathrm{Dv} & \overline{\mathrm{O}} \mathrm{u} / \overline{\mathrm{O}} \mathrm{uv} \\
\hline
\end{array} \\
& \begin{array}{llllll}
90^{\circ} & 6 & 2733 & 0.13 & 1 & 1
\end{array} \\
& \begin{array}{llllll}
60^{\circ} & 3 & 2677 & 0.02 & 0.87 & 0.98
\end{array} \\
& \begin{array}{llllll}
45^{\circ} & 3 & 2030 & 0.15 & 0.71 & 0.74
\end{array} \\
& \begin{array}{llllll}
30^{\circ} & 3 & 1517 & 0.09 & 0.50 & 0.56
\end{array}
\end{aligned}
$$

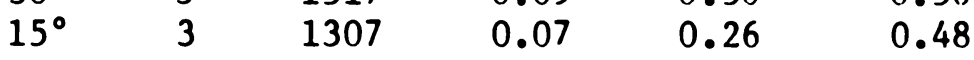

$$
\begin{aligned}
& \alpha_{2}=\text { angle of anchor shaft with horizontal } \\
& \mathrm{n}=\text { number of test performed } \\
& \overline{\mathrm{Q}}_{\mathrm{u}}=\text { average load capacity, } 1 \mathrm{~b} \\
& v=\text { coefficient of variation } \\
& \mathrm{D} / \mathrm{Dv}=\text { ratio of depth of inclined anchor to depth of vertical } \\
& \text { anchor } \\
& \bar{Q} \mathbf{u} / \bar{Q} u v=\text { ratio of average load capacity of inclined anchors to that } \\
& \text { of vertical anchors. }
\end{aligned}
$$

\subsubsection{3-1nch Single Helix Anchors}

The 3-inch single helix anchors were tested in order to evaluate size effects. In practice, these anchors do not have sufficient load capacity to be useable for mobile home tiedowns. This anchor is like a scaled-down 6-inch single helix anchor and should therefore afford a good comparison. The depth of the helix plate of a vertically-installed 3-inch helix anchor is approximately 25 inches, which gives an D/B ratio of 8.3. Thus, the vertical anchors probably acted like "deep" anchors. Table 4.4 gives a comparison of the load capacities of. 6-1nch and 3-1nch anchors: Table 4.4 Comparison of Load Capacities of 3 -in and 6-in
Single Helix Anchors

\begin{tabular}{llccc} 
Anchor Size & Loading & No. Tested & $\bar{Q}$ u 1 b & v \\
\hline 6-1nch & Vertical & 8 & 5212 & 0.12 \\
3-1nch & Vertical & 5 & 1650 & 0.17 \\
6-1nch & $45^{\circ}$ Coaxial & 3 & 4247 & 0.06 \\
3-1nch & $45^{\circ}$ Coaxial & 3 & 1102 & 0.02
\end{tabular}


In accordance with the above tabulation, the ratio of load capacities between the 6-inch and the 3-inch anchor was 3.16 for the vertical anchors and 3.85 for the $45^{\circ}$ anchors. The ratio of the helix areas is 4 . Thus, the load capacity of the 3-inch anchors was higher than the capacity that would be predicted on the basis of the ratios between the helix areas. This phenomenon will be further discussed under "prediction of anchor-load capacity."

Typical 3-inch single helix anchor tests are shown in figure 4.17. Note that the vertical scale was expanded because of the small failure loads. The behavior of these anchors was rather ductile which is taken as another indication that they acted as deep anchors.

\subsubsection{Self-seating Swivel Anchors}

In figure 4.18, the load-displacement characteristics of the self-seating swivel anchors tested are compared with those of 6-inch single helix anchors. Because of the large displacement associated with the virgin load-displacement curves for self-seating swivel anchors, the displacment scale was compressed. Note that extremely large displacements are required to develop the load capacity of the swivel anchors. Part of this displacement is attributable to the fact that the anchor must be rotated (upset) before it develops substantial resistance. Note that for both, the vertically-pulled and diagonally-pulled swivel anchors, a displacement of about 15 inches was required to develop a 4 kip load capacity. Upon unloading, these anchors had re-loading characteristics similar to those of the helix anchors, and in the case of the $45^{\circ}$ pull, the re-loading characteristics of the swivel anchors were sliperior to those of the 6-in single helix anchors. (Note that these anchors have cables, and that under coaxial pull, these cables will extend (elongate) much more than the $5 / 8$ in or $3 / 4$ in anchor stems of the helix anchors.)

Hereafter are some comparisons which give an indication of the effect of anchor area and direction of pull on load capacity. 


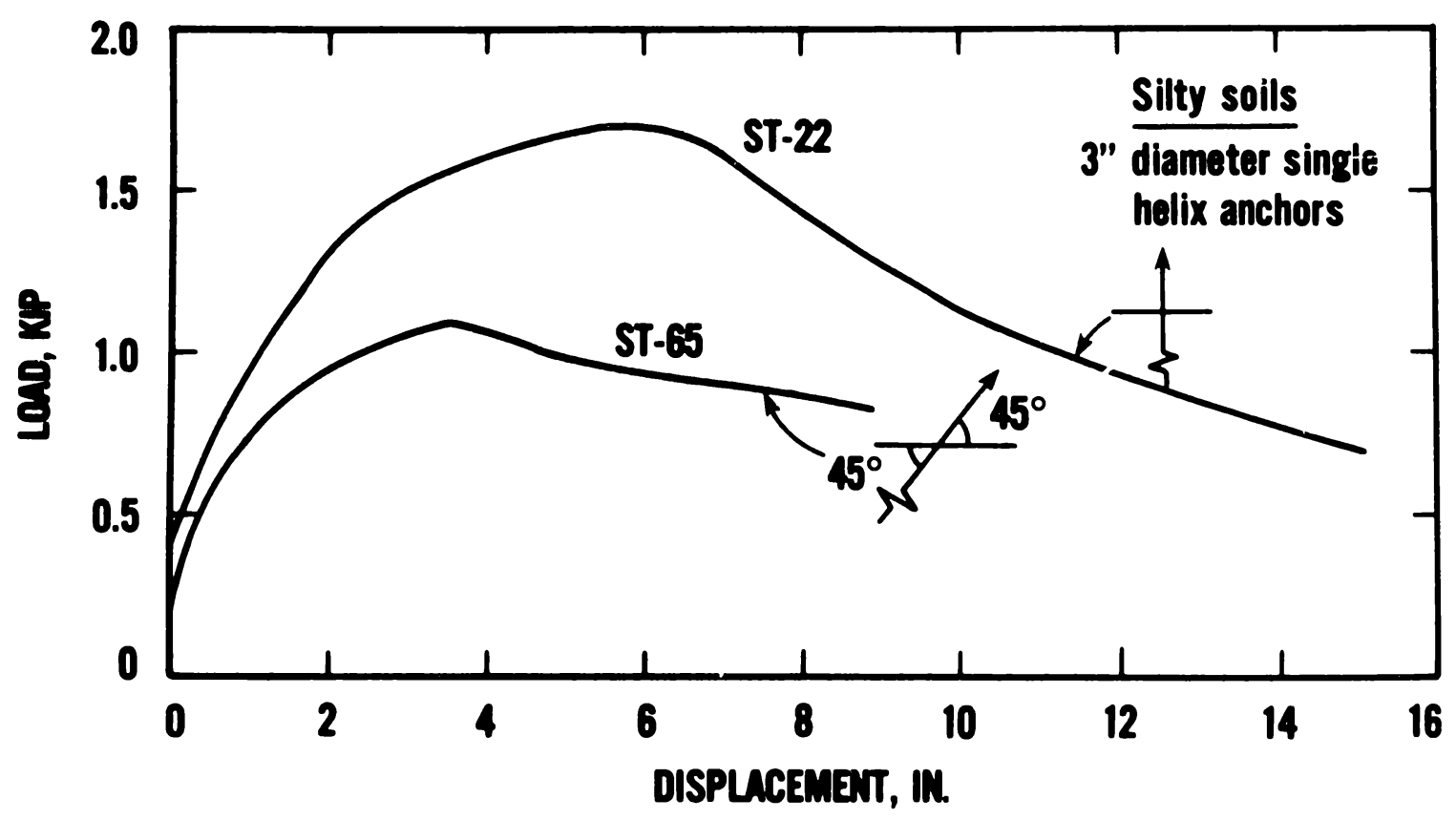

Figure 4.17 Tests of 3-1n single helix anchors in silty soils 


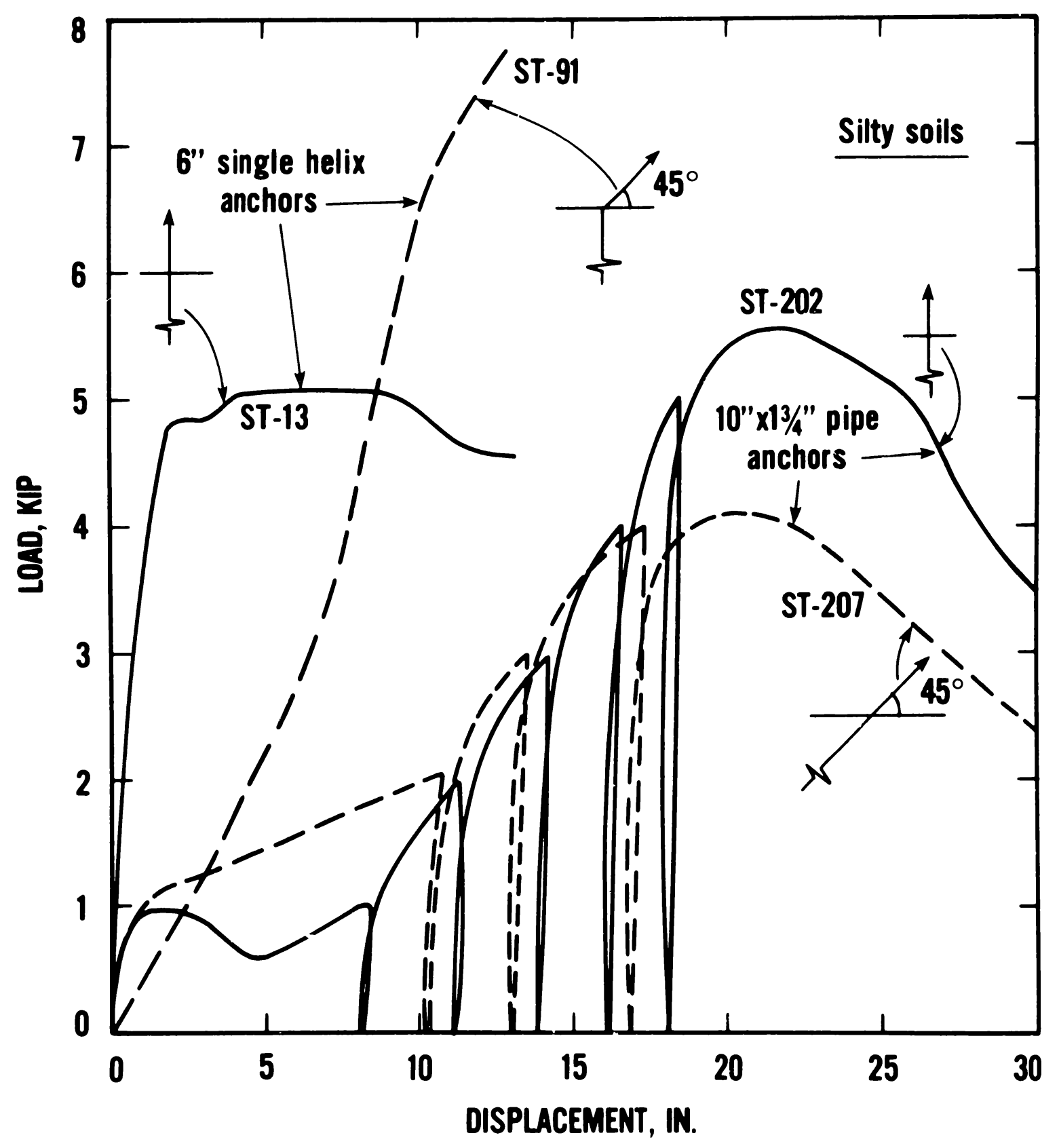

Figure 4.18. Load-displacement characteristics of self seating swivel anchors in silty soil 
Table 4.5 Load Capacity of Self-Seating Swivel Anchors Tested in Silty So1ls

\begin{tabular}{|c|c|c|c|c|}
\hline Anchor Type & $\begin{array}{c}\text { Projected Area } \\
\text { in }^{2} \\
\end{array}$ & $\underline{\mathrm{n}}$ & $-\underline{1}$ & $\bar{Q}_{\underline{u}, 1 b}$ \\
\hline Pipe & 17.9 & 2 & Vert. & 5,400 \\
\hline Plpe & 17.9 & 3 & $60^{\circ}$ & 5,100 \\
\hline Pipe & 17.9 & 2 & $45^{\circ}$ & 3,250 * \\
\hline Plpe & 8.5 & 1 & Vert. & 3,300 \\
\hline Pipe & 8.5 & 1 & $60^{\circ}$ & 2,800 \\
\hline Plpe & 8.5 & 1 & $45^{\circ}$ & 2,500 \\
\hline Triangular & 15.6 & 1 & Vert. & 5,100 \\
\hline Triangular & 15.6 & 1 & $60^{\circ}$ & 5,300 \\
\hline Triangular & 15.6 & 1 & $45^{\circ}$ & 5,000 \\
\hline
\end{tabular}

* One of these anchors was not fully seated during the pull. The other anchor had a load capacity of 4,200 $1 \mathrm{~b}$.

Table 4.5 represents very few specimens and hence there is not enough evidence to establish definitive conclusions. However, the table reveals some consistent trends:

1. Load capacity increases with the projected area of the anchor. This relationship seems to hold even when two entirely different anchor types are compared, and will be further discussed under "prediction of load capacity."

2. Vertically-pulled pipe anchors seem to have a higher load capacity than those pulled at an angle and load capacity seems to decrease when the angle of pull with the horizontal decreases. (All pipe anchors were installed vertically. An initial pull was needed to orient the cable in the direction of the pull.)

3. The triangular anchors' load capacity does not seem to change with the angle of pull.

It 18 also of interest to note that one of the pipe anchors pulled was not fully seated by the load.

Another important characteristic that needs to be examined is the re-loading modulus. These modull do not seem to be affected by the angle of pull and appear to be rather consistent. They are tabulated in table 4.6 . It 1s obvious from table 4.6 that properly seated, pre-loaded swivel anchors could provide load-displacement characteristics superior to those required in the ANS I A.119.3 standard, provided that they develop the required load capacity. 
Table 4.6 Re-loading Modull of Swivel Anchors Tested in Silty Soils

\begin{tabular}{|c|c|c|c|c|}
\hline $\begin{array}{c}\text { Anchor } \\
\text { Type }\end{array}$ & $\begin{array}{c}\text { Profected } \\
\text { Area } \\
1 n^{2}\end{array}$ & $\begin{array}{r}\text { No. of } \\
\text { Tests }\end{array}$ & $\mathrm{R}_{851 \mathrm{~b} / \mathrm{in}}$ & $\begin{array}{c}\text { Coefficient of } \\
\text { Variations of } \\
\text { R85 }_{85}\end{array}$ \\
\hline $\begin{array}{l}\text { Pipe } \\
\text { P1pe } \\
\text { Arrowhead }\end{array}$ & $\begin{array}{r}17.9 \\
8.1 \\
15.6\end{array}$ & $\begin{array}{l}5 \\
3 \\
3\end{array}$ & $\begin{array}{r}10,400 \\
6,500 \\
7,300\end{array}$ & $\begin{array}{l}0.1 \\
0.07 \\
0.05\end{array}$ \\
\hline
\end{tabular}

\subsection{EFFECT OF SOIL CHARACTER IST ICS}

\subsubsection{Coaxially Loaded Vertical Anchors}

Figure 4.19 shows a comparison between the load-displacement characteristics of coaxial pullout tests on 6-inch single helix anchors tested on the sand, silt and clay site. Test ST13 is from the silty site (Site A), Test SD25 from the sandy site (S1te B) and Test C7 from the clay site (Site C). Note that tests ST13 and C7 exh1bit considerable duct111ty, while anchor SD25 rapidly lost its load capacity after the peak resistance was developed. The characteristics 1llustrated by the figure were typical for most tests on the three sites. The difference in ductility between the anchors on the sandy site, and those on the silty and clay sites is attributable to the shear-strength characteristics of these so1ls. The clay derives most of 1 ts strength from cohesion which does not substantially decrease with shear strain or minor decrease in depth. The results of the unconfined compression and direct shear tests for the silt indicate that this material also has substantial cohesive strength as well as frictional shearing resistance. The sand, on the other hand, derives its strength from frictional shearing resistance. To the extent that there is cohesive strength in the sand, it is derived from cementation and thus would disappear as soon as a slip surface develops. Thus the shear strength of the sand depends primarily on confining pressures which, in turn, are a function of present overburden pressure and overconsolidation (a stress history of higher vertical pressures in the past). Fresent overburden pressures are a function of depth and thus tend to decrease as the anchor is pulled out. Increased confining pressures due to overconsolidation are relleved as shear deformations become large, and thus will rapldly disappear as the anchor is withdrawn. There is evidence that the sand deposits on Site $B$ are overconsolidated. The site itself was on the bottom of a borrow pit from which 20 to $30 \mathrm{ft}$. of material were removed. In addition, it has been determined that these sand deposits were overconsolidated during their geologic history. It will be shown later in this report that the magnitude of the load capacity of the anchors on site B gives further corroborative evidence of overconsolidation.

\subsubsection{Vertically Installed Anchors Pulled at an Angle}

F1gure 4.20 compares the load-displacement characteristics of vertical. anchors installed on the three test sites and pulled at a $40^{\circ}$ angle. Note that the 


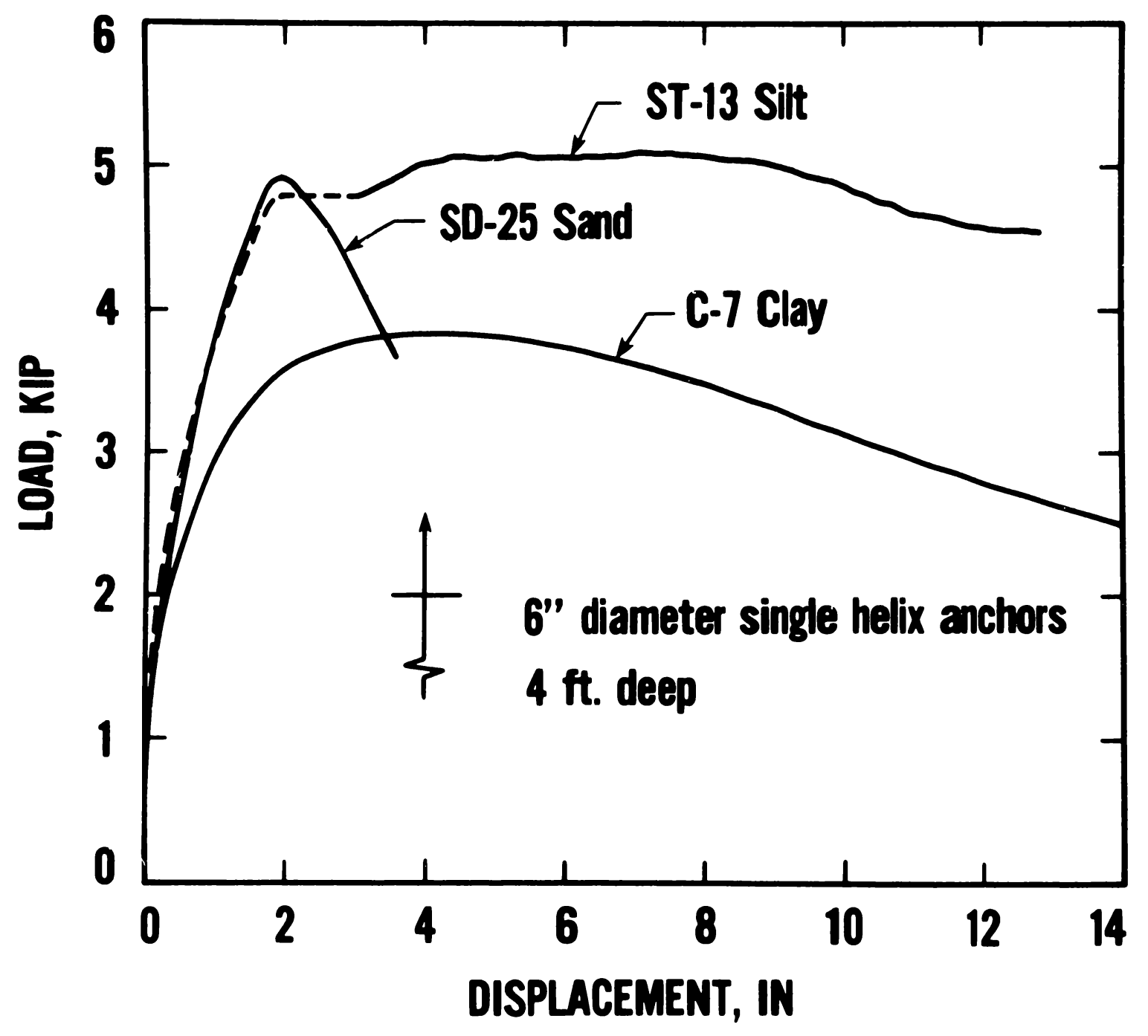

Figure 4.19 Load-displacement characteristics of coaxially loaded 6-in single hellx anchors on the sand, silt and clay sites. 


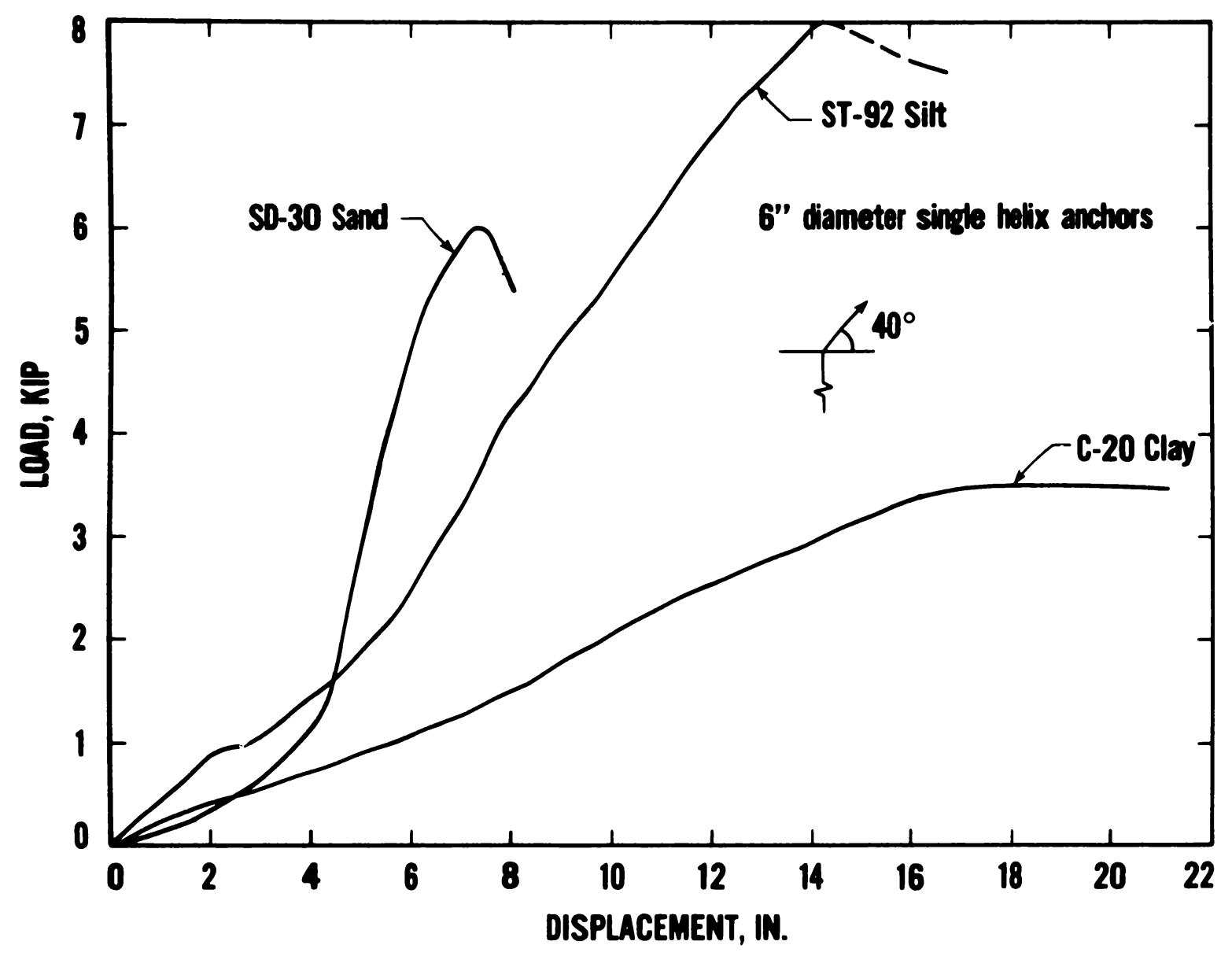

Figure 4.20 Vertically installed 6-in single helix anchors pulled at $a 40^{\circ}$ angle on the sand, silt and clay site 
initial anchor stiffness on the sandy site was less than that on the silt and clay sites. However, the stiffness on the sandy site increased rapidly with increasing loads and the peak resistance was reached at a smaller displacement than that in the silt and clay site. It is noteworthy that while on the sandy and silty site the load capacity of vertical anchors pulled at an angle tended to be higher than that of axially-pulled vertical anchors, a similar increase in load capacity did not occur on the clay site. This can be explained by the fact that the compressive forces exerted in this loading mode on part of the soll mass surrounding the anchor (see section 4.3.7) substantially increased the shear strength of the sands and silts, which increases with increasing confining pressures, but not that of the clays, which entirely depends on cohesion and thus tends to be independent of confining pressures. Table 4.7 summarizes the observed trends.

Table 4.7 Comparison of the: Effects of Load Inciination on the Load Capacities of Vertically Installed Anchors on Sites, A, B, and $\mathrm{C}$

\begin{tabular}{|c|c|c|c|c|c|c|}
\hline Soil & Anchor & $\bar{Q}_{u v}, 1 b$ & v & $\bar{Q}_{\mathbf{u} i}, 1 \mathrm{~b}$ & v & $\overline{\mathrm{Q}}_{\mathbf{u} \mathbf{1}} / \overline{\mathrm{Q}}_{\mathbf{u v}}$ \\
\hline Silt & $\begin{array}{ll}\text { 6" } & \text { S.H. } \\
\text { 4" } & \text { D. H. } \\
\end{array}$ & $\begin{array}{l}5170 \\
2730 \\
\end{array}$ & $\begin{array}{l}0.10 \\
0.13 \\
\end{array}$ & $\begin{array}{l}7930 \\
3623 \\
\end{array}$ & $\begin{array}{l}0.02 \\
0.07 \\
\end{array}$ & $\begin{array}{l}1.53 \\
1.33 \\
\end{array}$ \\
\hline Sand & $\begin{array}{ll}6^{\prime \prime} & \mathrm{S} . \mathrm{H} \\
4^{\prime \prime} & \mathrm{D} . \mathrm{H} . \\
\end{array}$ & $\begin{array}{l}5290 \\
1610^{\mathrm{b}} /\end{array}$ & $\begin{array}{l}0.08 \\
0.08 \\
\end{array}$ & $\begin{array}{l}6190 \\
2740 \\
\end{array}$ & $\begin{array}{l}0.05 \\
0.16 \\
\end{array}$ & $\begin{array}{l}1.17^{a} / \\
1.70\end{array}$ \\
\hline Clay & $\begin{array}{ll}\text { 6" S.H. } \\
4 " \text { D.H. }\end{array}$ & $\begin{array}{l}3430 \\
1930\end{array}$ & $\begin{array}{l}0.16 \\
0.03\end{array}$ & $\begin{array}{l}3270 \\
2130\end{array}$ & $\begin{array}{l}0.21 \\
0.16\end{array}$ & $\begin{array}{l}0.95 \\
1.10\end{array}$ \\
\hline
\end{tabular}

$-$

$Q_{u v}=$ Average ultimate load capacity in vertical pull, $1 \mathrm{~b}$

$\overline{\mathrm{Q}}_{\mathrm{ui}}=$ Average ultimate load capacity in inclined pull $\left(45^{\circ}\right), 1 \mathrm{~b}$

$v=$ Coefficient of variation

a/ Helix in the anchor broke off

b/ Tests SD2 and SD3 were excluded from average because they were influenced by a dense $1 \mathrm{ft}$. crust overlying the sand. Inclusion of those tests would inrease $Q$ to $2,3001 \mathrm{~b}$. and $v$ to 0.41 


\subsubsection{Effect of Depth and Anchor Inclination of Coaxial Load Capacity}

It is important to determine whether the trends which were observed on Site A also occurred on Sites $B$ and $C$. The observed trends are summarized in the following tables.

In table $4.8 a, Q_{u}$ is the average load capacity and $v$ is the coefficient of variation. Whenever $v$ is not given, the average is an average of only two tests. Even though the number of tests was $11 \mathrm{mited}$, some trend can be recognized from table $4.8 \mathrm{~b}$.

In the s1lt, the an'hors probably acted as "deep anchors" from a depth somewhere between 3 and $4 \mathrm{ft}$. Above this "critical" depth, load capacity seems to be roughly proportional to depth. On the clay site, load capacity is roughly proportional to depth, if depth is expressed as a fraction of the full (45 in.) depth.

For the sand, load capacity decreases more rapidly with decreasing depth. Thus when the depth was 50 percent of the full 45-in depth, the load capacity was only 38 percent of the full load capac1ty, and at 70 percent of the depth, the load capacity was 50 percent. This trend is consistent with the shear strength characteristics of the sands. When shear strength is primarily a function of cohesive strength, the strength change with depth will be more moderate than for the case where shear strength depends on confining pressures.

Except for the case of the $15^{\circ}$ pull which was noted in the discussion of the tests on the silty site, table $4.8 \mathrm{gives}$ no indication that inclined anchors have higher load capacities than vertical anchors installed to the same depth.

Effects of anchor inclination on load capacity of coaxially loaded 4-1nch double helix anchors are shown in table 4.9.

The data give no indication that the trend which emerges for the silt site is also valid for the sand and clay sites. Unfortunately data for the latter two sites are not sufficient to establish any trends.

\subsubsection{Reloading Moduli}

The ru-loading characteristics recorded are $R_{85}$, the secant re-loading modulus at 85 percent of the load before unloading for the static tests, and $R_{10}$, the secant re-loading modulus in the tenth load cycle for the cyclic tests. Table 4.10 gives the range of measured re-loading modull for the three sites. Since the importance of re-loading characteristics was not recognized at the outset of this testing program, only limited data are avallable for the silty site. These data include only one static coaxial test on a helix anchor but many static tests on helix anchors which were installed vertically and pulled at an angle, for which the re-loading modulus included the rebound of the anchor shaft which generally accounts for most of the displacement. There is a possibility that the re-loading moduli on the clay site, where the soil was 
Table 4.8 Effect of Anchor Depth and Inclination on the Load Capacity of Coaxially Loaded 6-in Single Helix Anchors

Table 4.8a: Summary of Load Capacity

\begin{tabular}{|c|c|c|c|c|c|c|c|}
\hline \multirow[b]{2}{*}{ Depth } & \multirow[b]{2}{*}{$\alpha_{2}$} & \multicolumn{2}{|c|}{ Silt } & \multicolumn{2}{|c|}{ Sand } & \multicolumn{2}{|c|}{ Clay } \\
\hline & & $Q_{u}, 1 b$ & $\mathbf{v}$ & $Q_{u}, 1 b$ & $\mathbf{v}$ & $Q_{u}, 1 b$ & $\mathbf{v}$ \\
\hline $1^{\prime}$ & $90^{\circ}$ & 840 & 0.19 & & & 910 & \\
\hline $1.02^{\prime}$ & $15^{\circ}$ & 1450 & 0.11 & & & & \\
\hline $2^{\prime}$ & $90^{\circ}$ & 3200 & 0.03 & 2020 & & 1800 & \\
\hline $2^{\prime}$ & $30^{\circ}$ & 2880 & 0.24 & & & & - \\
\hline $2.83^{\prime}$ & $45^{\circ}$ & 4250 & 0.06 & 2650 & 0.05 & 2530 & 0.06 \\
\hline $3^{\prime}$ & $90^{\circ}$ & 5220 & 0.08 & 4480 & - & 2980 & - \\
\hline $3.46^{\circ}$ & $60^{\circ}$ & 4560 & 0.14 & & & & \\
\hline $4^{\prime}$ & $90^{\circ}$ & 5170 & 0.10 & 5290 & & 3430 & 0.16 \\
\hline
\end{tabular}

Table 4.8b: Load Reduction Rat108

\begin{tabular}{|c|c|c|c|c|c|}
\hline \multirow[b]{2}{*}{$\operatorname{Depth}^{\mathrm{a} /}$} & \multirow[b]{2}{*}{$\alpha_{2}$} & \multirow[b]{2}{*}{$D / D_{v}^{b /}$} & Silt & \multirow[t]{2}{*}{ Sand } & \multirow[t]{2}{*}{ Clay } \\
\hline & & & $Q_{u} / Q_{u v} c /$ & & \\
\hline $1^{\prime}$ & $90^{\circ}$ & $0.2 C$ & 0.16 & & 0.27 \\
\hline $1.02^{\prime}$ & $15^{\circ}$ & 0.26 & 0.28 & & \\
\hline $2^{\prime}$ & $90^{\circ}$ & 0.47 & 0.62 & 0.38 & 0.52 \\
\hline $2^{\prime}$ & $30^{\circ}$ & 0.50 & 0.56 & & \\
\hline $2.83^{\prime}$ & $45^{\circ}$ & 0.71 & 0.82 & 0.50 & 0.74 \\
\hline & $90^{\circ}$ & 0.73 & 1.01 & 0.85 & 0.87 \\
\hline $3.46^{\prime}$ & $60^{\circ}$ & 0.87 & 0.88 & & \\
\hline $4^{\prime}$ & $90^{\circ}$ & 1.00 & 1.0 & 1.0 & 1.0 \\
\hline
\end{tabular}

a/ "Depth" is the total depth to the tip of the anchor.

$\mathrm{b} /$ Depth ratio $\mathrm{D} / \mathrm{D}_{\mathrm{v}}$ is the actual depth to the center of the helix divided by the depth of the vertical anchor to the center of the helix.

c/ $Q_{u}=$ average ultimate load of tests.

$Q_{u v}=$ average ultimate load in vertical pull of anchors installed to their full depth. 
Table 4.9 Effects of Anchor Inclination on the Load Capacity of Coaxially Loaded 4-1n Double Helix Anchors

Table 4.9a. Summary of Load Capacities

\begin{tabular}{lllllllll} 
& & \multicolumn{2}{c}{ S11t } & & \multicolumn{2}{c}{ Sand } & & \multicolumn{2}{c}{ Clay } \\
\cline { 3 - 5 }$\sigma_{2}$ & $D / D_{v}$ & $\bar{Q}_{u}, 1 b$ & $v$ & & $\bar{Q}_{u}, 1 b$ & $v$ & $\bar{Q}_{u}, 1 b$ & $v$ \\
\hline $90^{\circ}$ & 1 & 2730 & 0.13 & $1610^{a} /$ & 0.08 & 1930 & 0.03 \\
$60^{\circ}$ & 0.87 & 2680 & 0.02 & & & & \\
$45^{\circ}$ & 0.71 & 2030 & 0.15 & 1813 & 0.24 & 1780 & - \\
$30^{\circ}$ & 0.5 & 1500 & 0.08 & & & & \\
$15^{\circ}$ & 0.26 & 1310 & 0.07 & & & & & \\
\hline
\end{tabular}

Table 4.9b. Load Reduction Ratios

\begin{tabular}{|c|c|c|c|c|}
\hline \multirow[b]{2}{*}{$\sigma_{2}$} & \multirow[b]{2}{*}{$\mathrm{D} / \mathrm{D}_{\mathbf{v}}$} & S11t & \multirow{2}{*}{$\frac{\text { Sand }}{Q_{u v} / Q_{u}}$} & \multirow[t]{2}{*}{ Clay } \\
\hline & & & & \\
\hline $90^{\circ}$ & 1 & 1 & 1 & 1 \\
\hline $60^{\circ}$ & 0.87 & 0.98 & & \\
\hline $45^{\circ}$ & 0.71 & 0.74 & 1.13 & 0.92 \\
\hline $30^{\circ}$ & 0.50 & 0.55 & & \\
\hline $15^{\circ}$ & 0.26 & 0.48 & & \\
\hline
\end{tabular}

a/ Tests conducted on the part of the sand site overlain by the dense crust are not included in this average. 
saturated, are influenced by the buildup of porewater pressure gradients. If this was the case, the moduli may be substantically lower in very slow tests. Some general conclusions can be drawn from table 4.10 .

1. In all instances, the re-loading modulus exceeded the stiffness requirements of ANS I Standard Al19.3 by a substantial margin (see section 4.8).

2. The re-loading moduli in the coaxial tests tended to be much higher than those in the non-coaxial tests.

3. The re-loading moduli in the cyclic tests tended to exceed those in the static tests with the same loading conditions.

4. The re-loading moduli of the helix anchors varied over a considerable range; th je of the swivel anchors tended to be quite predictable and increased with increasing anchor-plate (projected anchor area) size.

\subsection{PREDICTION OF ANCHOR-LOAD CAPACITY}

\subsubsection{General}

Three methods have been uied to predict anchor-load capacity:

1. Correlation of anchor-load capacity with in situ tests [in particular, correlation with Soll Test Probe (STP) measurements are widely used by industry];

2. Determination of load capacity on the basis of measured or estimated shear strength characteristics of the soll and some analytical model which assumes a fallure mechanism;

3. Determination of load -apacity on the basis of pullout tests in simflar soll conditions.

Method 1 is used by industry with some success. Many theoretical studies have been conducted in conjunction with method 2; however, it is diffult, and relatively expensive to determine the shear strength of the soll, and the characteristics of solls at shallow depths increase these difficulties. Method 3 is used by many states to certify anchors; however, its validity is questionable when tests performed at one site are used to predict anchor capacity at another site where the shear strength of the soll may be different. 
4.10 Comparison of Reloading Modul1 Measured on the Three Test Sites Soll Type Anchor Type $\alpha_{1} \quad \alpha_{2} \quad R_{85}$ in $1 b / 1 n \quad R_{10}$ in $1 b / 1 n$

\begin{tabular}{|c|c|c|c|c|c|}
\hline \multirow{5}{*}{ SILT } & $\mathrm{H}-6$ & $\begin{array}{l}90^{\circ} \\
60^{\circ} \\
45^{\circ} \\
30^{\circ} \\
15^{\circ}\end{array}$ & $\begin{array}{l}90^{\circ} \\
90^{\circ} \\
90^{\circ} \\
90^{\circ} \\
90^{\circ}\end{array}$ & $\begin{array}{r}17,000 \\
1,700-\quad 2,300 \\
2,700-3,600 \\
2,100-5,000 \\
3,500-7,800\end{array}$ & $20,500->50,000$ \\
\hline & $D-4$ & $\begin{array}{l}90^{\circ} \\
60^{\circ} \\
45^{\circ} \\
30^{\circ} \\
15^{\circ}\end{array}$ & $\begin{array}{l}90^{\circ} \\
90^{\circ} \\
90^{\circ} \\
90^{\circ} \\
90^{\circ}\end{array}$ & $\begin{array}{l}2,000-3,700 \\
3,400-6,200 \\
2,000-2,450 \\
3,400-5,200\end{array}$ & $>50,000$ \\
\hline & $A H-6^{a /}$ & $\begin{array}{l}90^{\circ} \\
60^{\circ} \\
45^{\circ}\end{array}$ & $\begin{array}{l}90^{\circ} \\
90^{\circ} \\
90^{\circ}\end{array}$ & $\begin{array}{l}7,100 \\
7,700 \\
7,100\end{array}$ & \\
\hline & $P-10^{a /}$ & $\begin{array}{l}90^{\circ} \\
60^{\circ} \\
45^{\circ}\end{array}$ & $\begin{array}{l}90^{\circ} \\
90^{\circ} \\
90^{\circ}\end{array}$ & $\begin{array}{r}10,200 \\
9,000-11,300 \\
11,300\end{array}$ & \\
\hline & $P-6^{a /}$ & $\begin{array}{l}90^{\circ} \\
60^{\circ} \\
45^{\circ}\end{array}$ & $\begin{array}{l}90^{\circ} \\
90^{\circ} \\
90^{\circ}\end{array}$ & $\begin{array}{l}6,400 \\
6,200 \\
7,100\end{array}$ & \\
\hline \multirow[t]{2}{*}{ SAND } & $\mathrm{H}-6$ & $\begin{array}{l}90^{\circ} \\
40^{\circ} \\
45^{\circ}\end{array}$ & $\begin{array}{l}90^{\circ} \\
45^{\circ} \\
90^{\circ}\end{array}$ & $\begin{array}{r}10,000-24,000 \\
14,200->50,000 \\
5,900-6,200\end{array}$ & $\begin{array}{l}12,400-20,600 \\
13,500-20,700\end{array}$ \\
\hline & $D-4$ & $\begin{array}{l}90^{\circ} \\
45^{\circ} \\
45^{\circ}\end{array}$ & $\begin{array}{l}90^{\circ} \\
40^{\circ} \\
90^{\circ}\end{array}$ & $\begin{array}{c}11,700-42,000 \\
>50,000 \\
10,100-16,400\end{array}$ & $\begin{array}{c}>50,000 \\
7,400-23,000\end{array}$ \\
\hline \multirow{2}{*}{ CLAY } & $H-6$ & $\begin{array}{l}90^{\circ} \\
45^{\circ} \\
45^{\circ}\end{array}$ & $\begin{array}{l}90^{\circ} \\
45^{\circ} \\
90^{\circ}\end{array}$ & $\begin{array}{r}7,600-13,700 \\
13,600-21,200 \\
8,500-9,300\end{array}$ & $\begin{array}{r}9,000->50,000 \\
1.2,000-40,000\end{array}$ \\
\hline & $D-4$ & $\begin{array}{l}90^{\circ} \\
45^{\circ} \\
45^{\circ}\end{array}$ & $\begin{array}{l}90^{\circ} \\
45^{\circ} \\
90^{\circ}\end{array}$ & $\begin{array}{r}13,500-42,500 \\
8,500-21,300 \\
1,700-14,700\end{array}$ & $\begin{array}{r}20,000->50,000 \\
3,500-5,700\end{array}$ \\
\hline
\end{tabular}

a 3 In the swivel anchors which were installed vertically and pulled at an angle, the cable aligned itself in the direction of the pull. 


\subsubsection{Correlation of Anchor Capacity with In Situ Tests}

\section{(1) General}

Three in-situ test methods were used to determine soil properties: the Soil Test Probe (STP); the installation torque of the anchor; and the Standard Penetration Test (SPT).

\section{(2) So11 Test Probe (STP)}

Correlations between STP readings and coaxial pullout tests on vertical 6-in. single helix anchors installed to their full depth are given in figure 4.21. The STP torque correlated with the test results is the reading taken with the tip of the instrument at $4 \mathrm{ft}$. depth, which is influenced by the shear strength of the soil between the depths of 3 and $4 \mathrm{ft}$. It should be noted that while in the silty soil the readings between $2 \mathrm{ft}$ and $4 \mathrm{ft}$ tip elevation did not tend to increase very much, there was a steady increase in the torque with depth in the sand.

The solid points in the figure indicate ultimate strength $\left(Q_{u}\right)$ and the open points anchor load at 2 in withdrawal $\left(P_{2 v}\right)$. Load $P_{2 v}$ was plotted because $1 t$ corresponds to the "load capactiy" as defined in ANS I Standard Al19.3. Round points are for silt, triangles for sand and squares for clay. Note that there is a definite correlation between STP reading and pullout strength. For the tests plotted, average $Q_{u}$ can be estimated by the equation

$$
Q_{u}=2300+11 t
$$

where: $Q_{u}=$ average pullout strength in $1 \mathrm{~b}$.

$$
t=\operatorname{STP} \text { torque at } 4 \mathrm{ft} \text { tip penetration in in.-lb. }
$$

A reasonable lower bound for $Q_{u}$ is given by:

$$
Q_{u} \geq 1300+11 t
$$

$(e q \cdot 4.2)$

Tests ST26 and ST25 were not considered in deriving eqs. 4.1 and 4.2 . The loaddisplacement characteristics of Test ST26 were different from those of other anchors, indicating that perhaps a root or some other object impeded the withdrawal. The STP reading for Test ST25 showed a sudden drastic increase in torque at the $4 \mathrm{ft}$ level, while the torque at other depths was relatively low. Thus, it is reasoned that the probe hit an obstruction or bedrock. This cond1tion would not increase anchor capacity. Note that in figure 4.21 all soil types fall into the same pattern.

A reasonable lower bound for $\mathrm{P}_{2 v}$ is given by:

$$
P_{2 v} \geq 600+11 t
$$




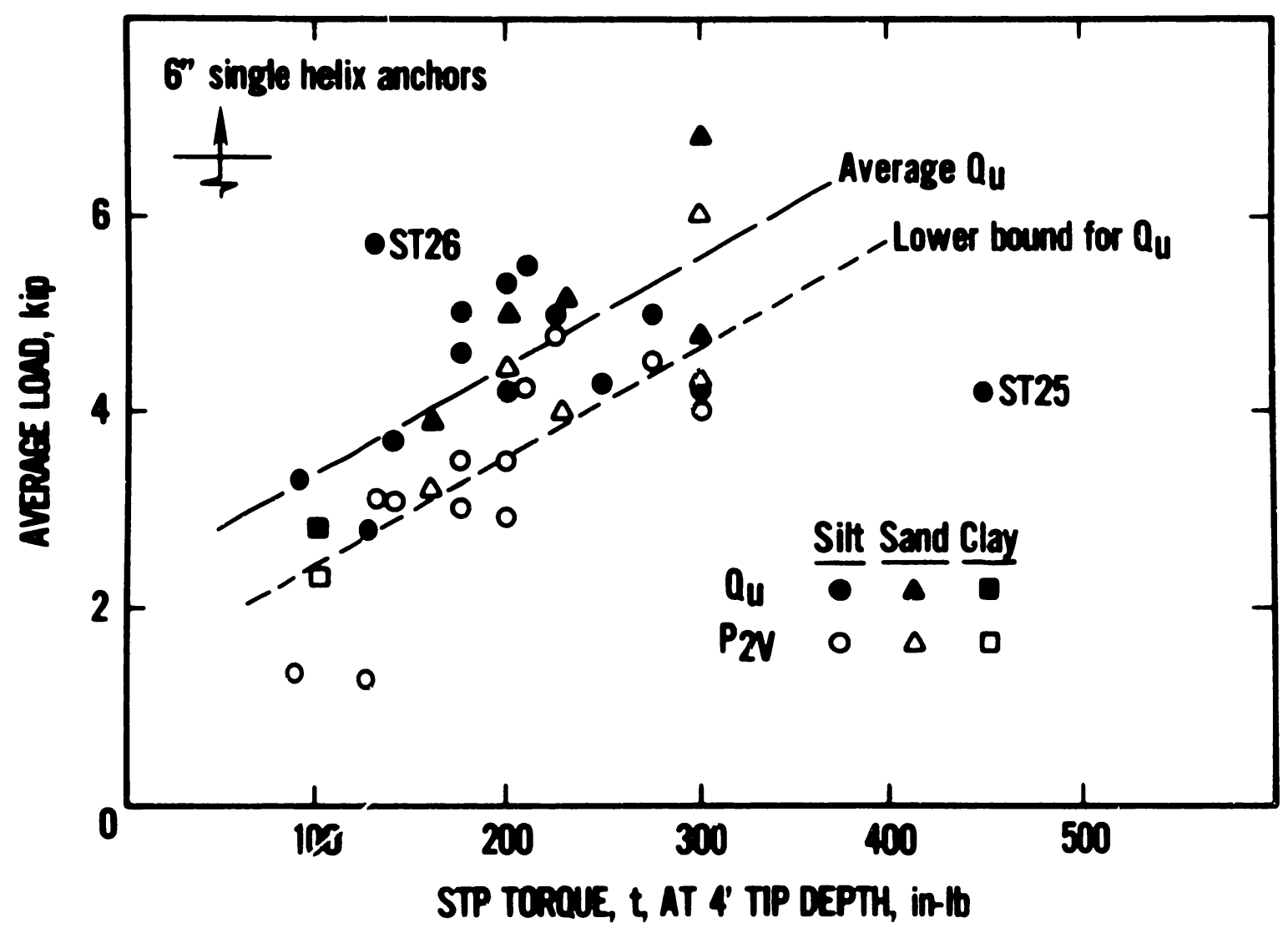

Figure 4.21 Correlation between Soll Test Probe readings and coaxial load capacity of vertically installed 6-in single helix anchors 
The correlation between pullout tests of 4-in double helix anchors and corresponding STP readings is shown in figure 4.22. Note that the STP readings were low for clav and high for sand when compared with the silt readings. The explanation for the low readings in clay is that the readings were affected hy pumping action resulting from excess pore water pressure bulldup and perhaps sensitivity of the clay (see also discussion of shear strength prediction on nage 70$)$. The readings in sand were $h 1 g h$, since the $4-i n$ double helix is basically a shallow anchor and its load capacity is influenced hy the shear strength of the soll between the depths of $\theta$ and $2.5 \mathrm{ft}$ (the load capacities of the 6-in single helix anchors which are deep anchors is more closely related to the shear strength of the soll near the hellx). The STP readings were taken with the $t: p$ at $3 \mathrm{ft}$ and the STP helix hetween 2 and $3 \mathrm{ft}$. This position perhaps best characterizes the shear strength close to $3 \mathrm{ft}$ depth. To get a better correlation, the STP reading was averaged over the $2.5 \mathrm{ft}$ depth of the lower anchor helix. This correlation is plotted in figure 4.23, and it can be seen that the sand and silt tests fall into a consistent pattern. A reasonably conservative prediction could he made by this equation:

$$
\left.n_{u} \geq 13 \bar{t} \quad \text { (eq. } 4.4\right)
$$

where: $\bar{t}$ is the torque averaged over the anchor depth

Since there is a iefinite correlation between the STP and anchor capacity, the question arises whether the STP can also be used to measure the shear strength of soils. This question was investigated using the "shallow" anchor tests, 1.e., those anchor tests which gave evidence that the fallure surface extended to the ground surface. These include anchors up to $3 \mathrm{ft}$ deep (refer to fizure 4.13 and table 4.8b). To calculate average shear strength, a cylindrical fa11ure surface was assumed, extending from the helix plate to the ground surface. Fven though it has been shown that the actual fallure mechanism is more complex (for instance Balla [6]), the assumed surface is a possible mechanism, and the shear resistance thus computed would therefore be equal to, or smaller than, the shear strength of the soll and constitute a lower bound for the shear strength. There is field evidence that the body of soll initially displaced mav have been greater than the assumed cylinder (refer to notes on soll. mounds formed in tables in appendix R.) However, as can be seen from figure 4.24, that experimental evidence does not preclude the assumed cylindrical surface as the primary mechanisms.

Figure 4.25 shows a plot of average shear resistance on the assumed cylindrical fallure surface against average STP readings. Tests $C 6, \operatorname{SD} 24$ and SD 47 which are for $4 \mathrm{ft}$ deep anchors were included since there is evidence that, unlike in the silt, the $4 \mathrm{ft}$ deep, 6-in single helix anchors in the sand and clay were on the borderline between deep and shallow anchors. A reasonable lower bound for the shear resistance, which in turn is a lower bound for the in-situ shear strength of the soll is given by the equation: 


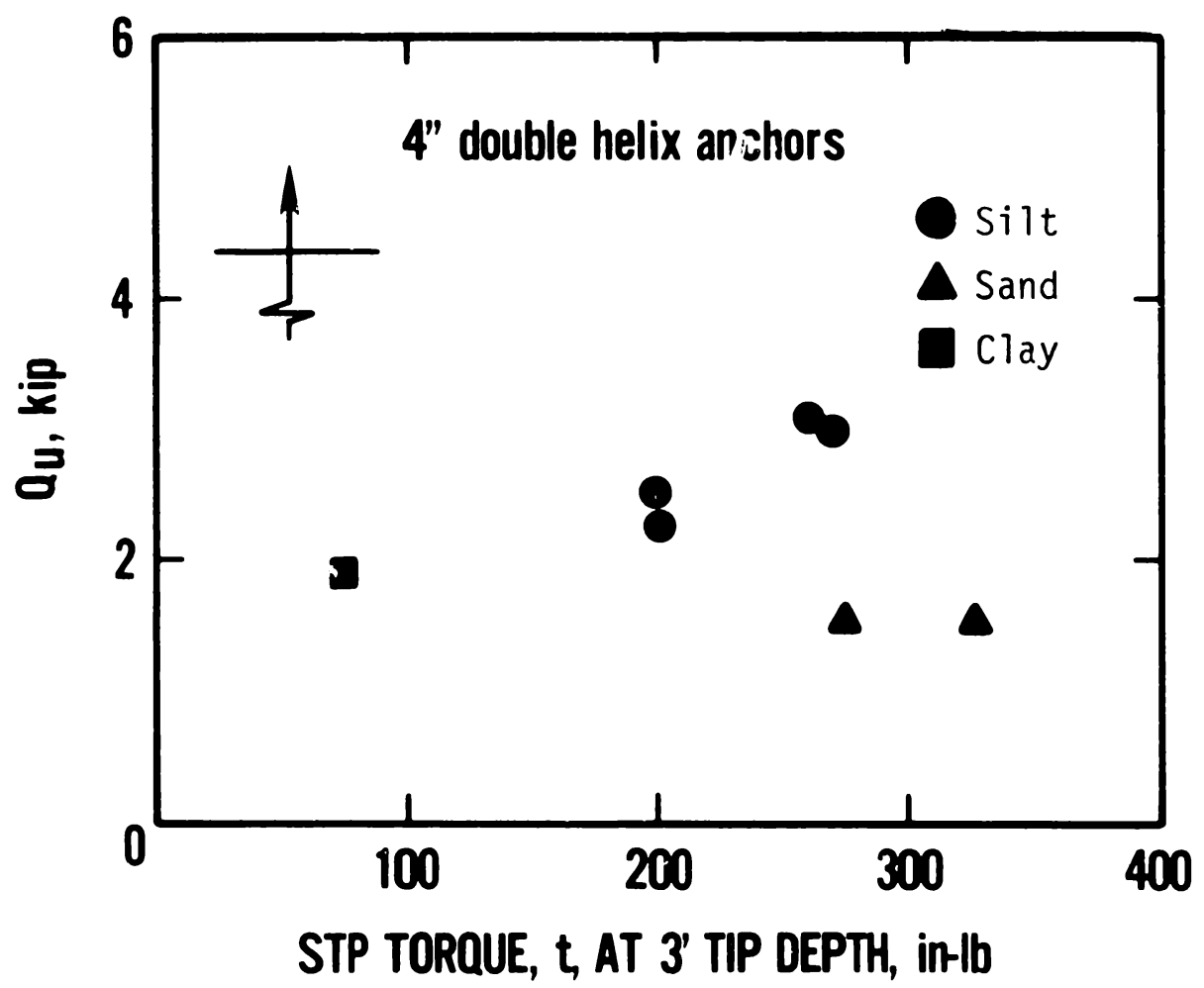

Figure 4.22 Correlation between Soll Test Probe readings and coaxial load capacity of vertically installed 4-in double helix anchors 


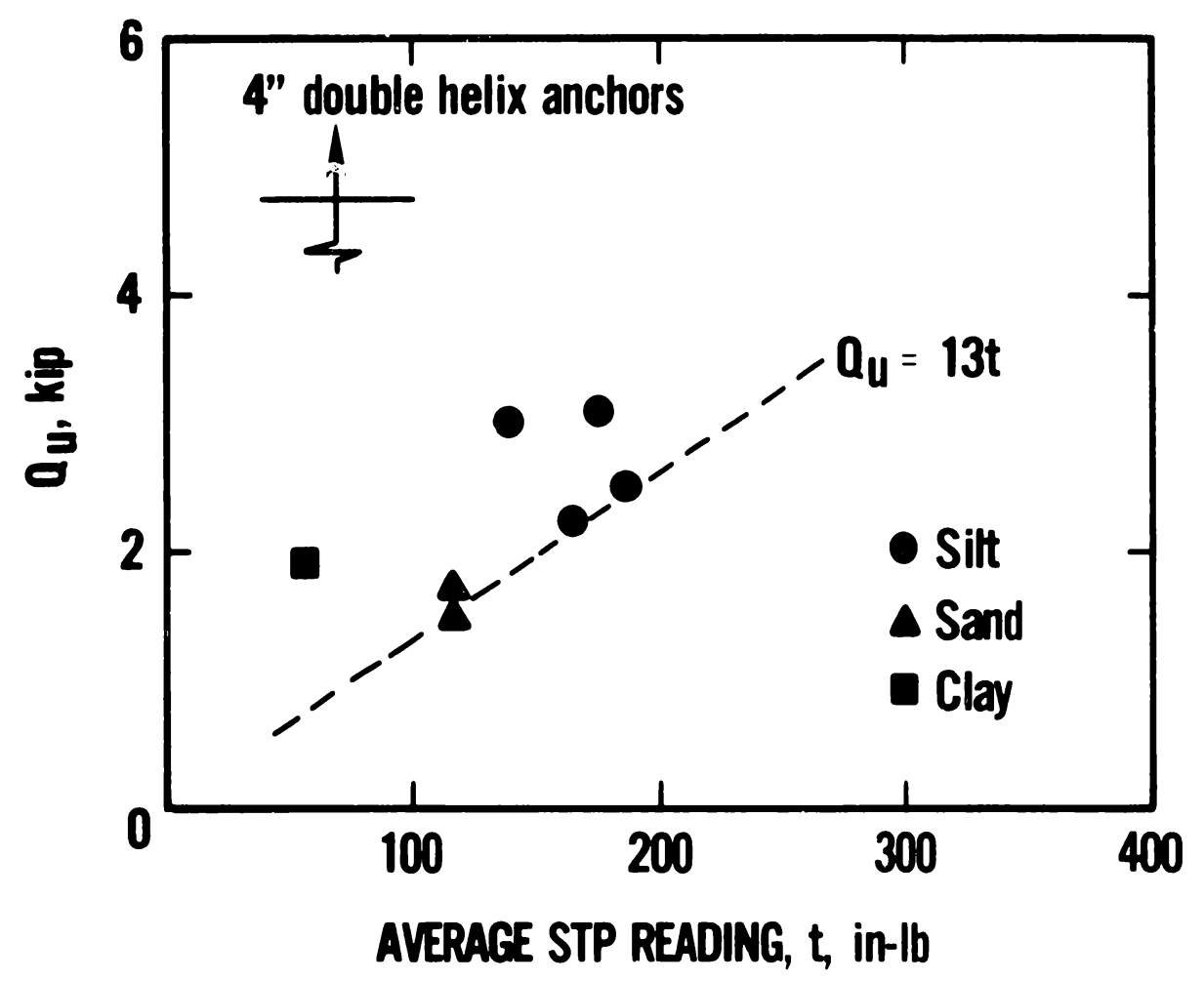

F1gure 4.23 Correlation between Soll Test Probe readings averaged over a $2.5 \mathrm{ft}$ depth and the load capacity of coaxially loaded 4-in double hellx anchors 


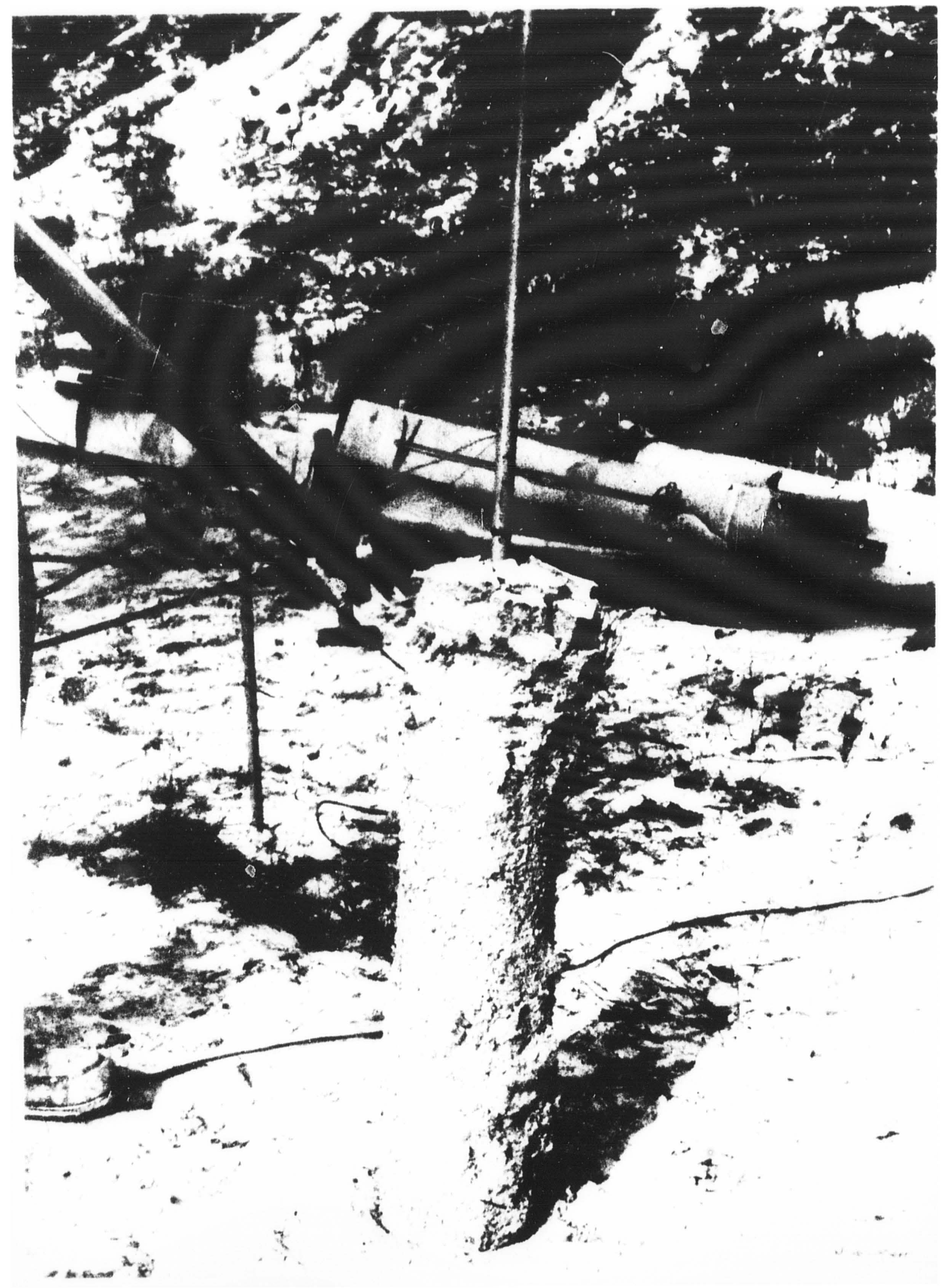

Figure $4.24 \quad 3 \mathrm{ft}$ deep 6 -in single hellx anchor after pullout on the sandy site 


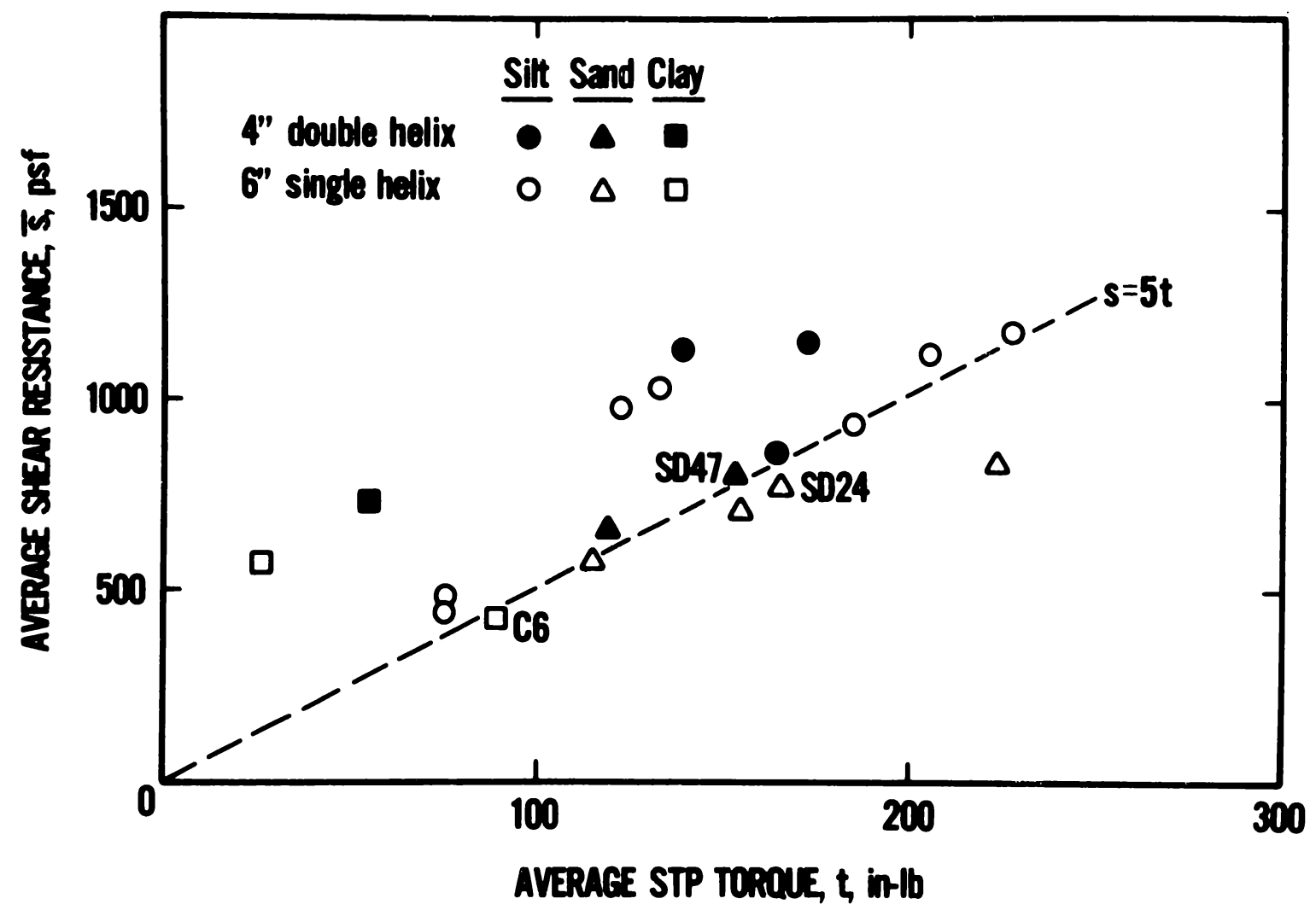

Figure 4.25 Relationship between STP measurements and the shear resistance of 8011 
where: $s=$ shear strength in psf

$$
t=\operatorname{STP} \text { torque in } 1 \mathrm{n}-1 \mathrm{~b}
$$

A statistical analysis of the results gives the following values:

for 10 tests in silt:

$$
\bar{s}=6.4 t ; \quad v=0.20
$$

for 6 tests in sand:

$$
\bar{s}=4.82 t ; v=0.13
$$

for the combined sand and silt tests (16 tests)

$$
\bar{s}=5.81 t ; v=0.22
$$

where: $\bar{s}=$ average shear strength in psf

$t=S T P$ reading in in-1b

$v=$ coefficient of variation of shear strength

The results for the clay site are inconsistent, with s/t ranging from 4.88 to 22.67. The extremely low torque readings on 2 out of the 3 tests on the clay site are attributed to porewater pressure bulldup and resulting pumping action, and perhaps sensitivity of the clay. Thus the STP may not be a good tool in saturated clays.

The $s / t$ ratio for the sand tended to be lower than that for the silt. A possible explanation of this phenomenon is the fact that in the silt torque did not change much between the depths of 1 and $3 \mathrm{ft}$. In the sand the torque steadily increased with depth. The shear strength of the soil affects the STP torque in two ways: by resistance at the lower tip of the STP; and by skin friction exerted on the helix of the instrument. If the measurement is primar1ly affected by tip resistance, then the shear strength measured when the tip of the STP is at $4 \mathrm{ft}$ may be characteristic for the depths from 3.5 to $4.5 \mathrm{ft}$, rather than for the depths from 3 to $4 \mathrm{ft}$ as was assumed herein. This would result in a lower $s / t$ ratio if the soil strength increases with depth and the average is calculated by the method used herein.

Further studies will be required to refine the use of the STP for the in situ measurement of the shear strength of solls.

\section{(3) Installation Torque, $T$}

The correlation between installation torque and anchor strength is shown in figures 4.26 and 4.27 , for 6-in single helix and 4-in double helix anchors, respectively. For the 6-in single helix anchors the scatter is considerable 


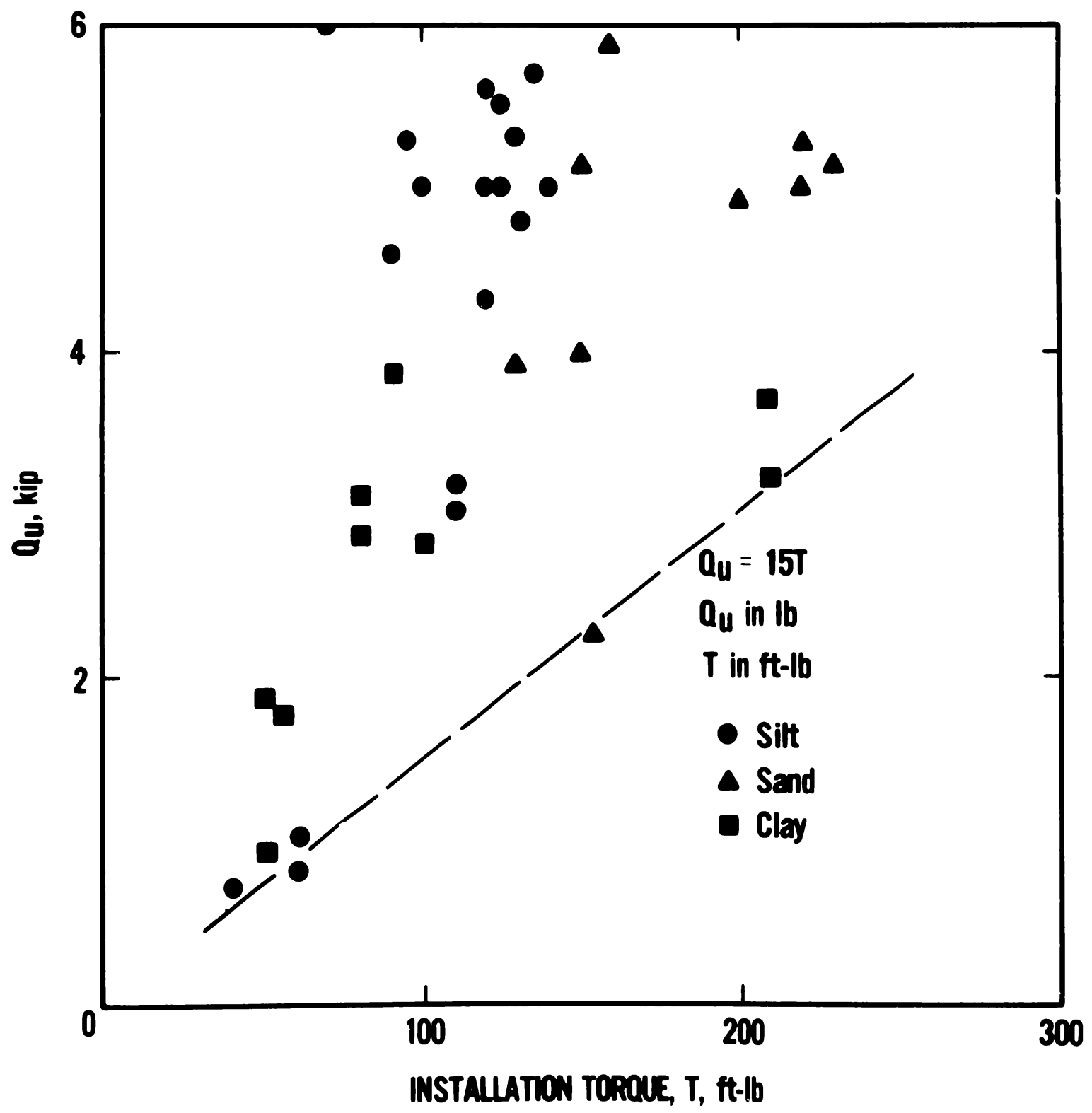

Figure 4.26 Relationship between installation torque and pullout strength for vertical, coaxially loaded 6-in single hellx anchors 


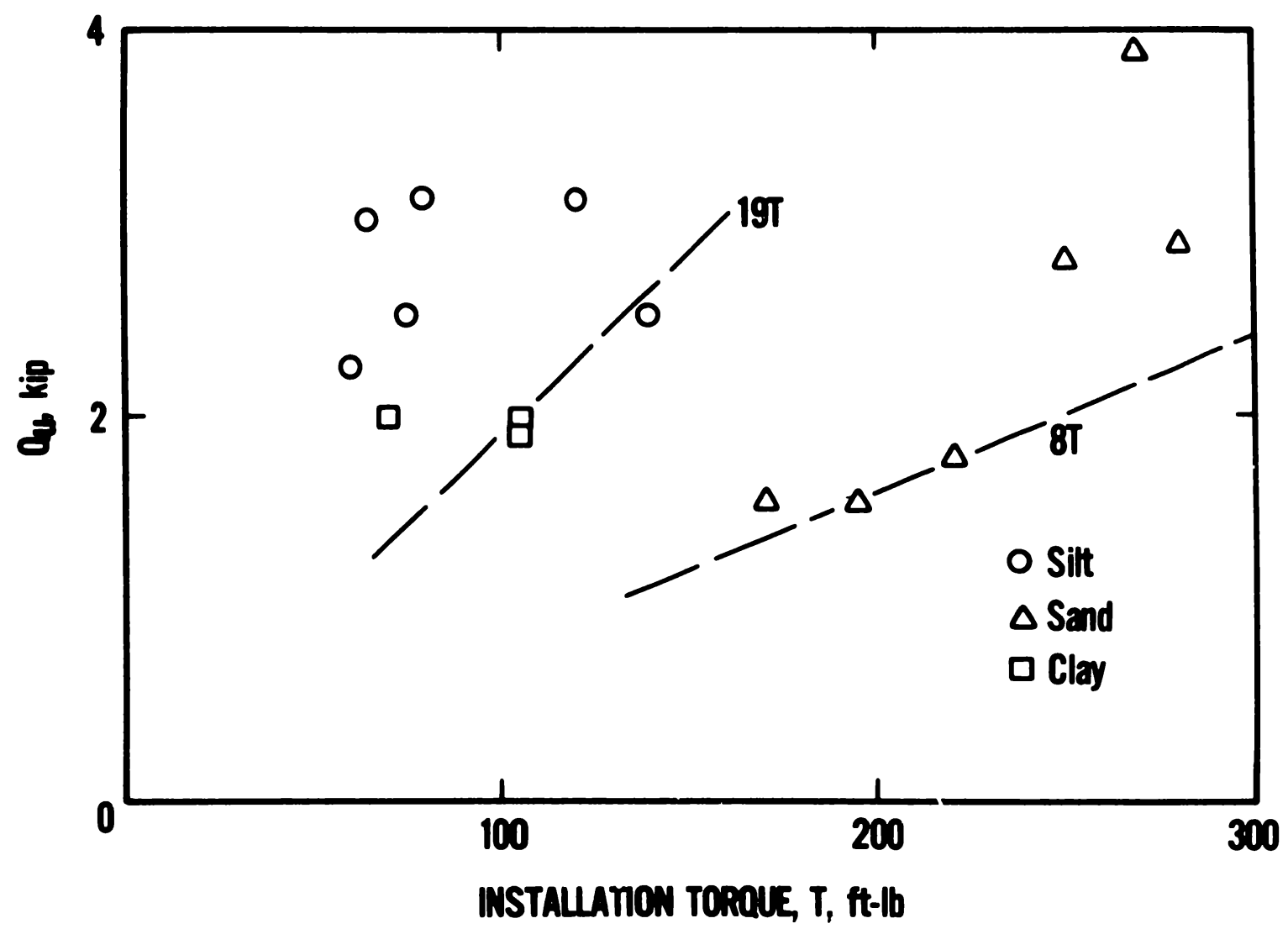

Figure 4.27 Relationship between installation torque and pullout strength for vertical, coaxially loaded 4-in double helix anchors 
and there is no observed trend related to soll type. A reasonable lower bound is given by the equation

$$
\mathrm{Q}_{\mathrm{u}} \geq 15 \mathrm{~T}
$$

$(e q \cdot 4 \cdot 9)$

where: $T=$ installation torque measured at maximum anchor penetration in $\mathrm{ft}-1 \mathrm{~b}$.

For the 4-in double helix there is a distinct difference between sand on one side, and silt and clay on the other side. A similar phenomenon was observed for the Soll Test Probe (figure 4.22) where the difference was eliminated when torque readings were averaged over the depth of the anchor. In the case of installation torque such a procedure would not be practical. Thus installation torque may be misleading as a strength measure for shallow anchors in solls in which shear strength increases rapidly with depth.

Equations for the lower bounds of $T$ vs. Nu are shown in figure 4.27. It should be noted that manufacturers recommend the equation:

$$
0_{u} \leq 10 \mathrm{~T}
$$

where $Q_{u}$ is in $1 b$ and $T$ in $f t-1 b$

which is considered conservative for the data presented herein.

(4) Standard Penetration Test (SPT)

The Standard Penetration Test is generally considered to correlate well with the shear strength of granular soils. However, in this instance, the exploration is shallow and drill stem lengths are therefore very short. It has been shown [15] that for drill stem lengths 1 ess than $10 \mathrm{ft}$. the energy delivered to the split spoon is extremely sensitive to the drill stem length. Thus, for this shallow exploration, one should expect erratic results from the SPT. The quantity of tests taken in this project does not permit a comparison of SPT counts with the strength of individual anchors. However, a comparison between STP readings and SPT blowcounts was made and is shown in figure 4.28. The scatter in the figure is considerable and no useful correlation can be derived.

\subsubsection{Theoretical Determination of Anchor-Load Capacity}

\section{(1) General}

Several hypotheses have been advanced which correlate anchor-load capacity with the in-situ shear strength and unit welght of the soll. All those hypotheses distinguish between "deep" and "shallow" anchors. In deep anchors the fallure (slip) surface does not extend to the ground surface. In general, the ratio of depth below the surface to anchor-plate width (D/B) is used to determined whether an anchor 18 deep or shallow. The anchors tested in this project have D/B ratios at full penetration depth which puts them close to the dividing point between deep and shallow anchors. This somewhat complicates data interpretation. 


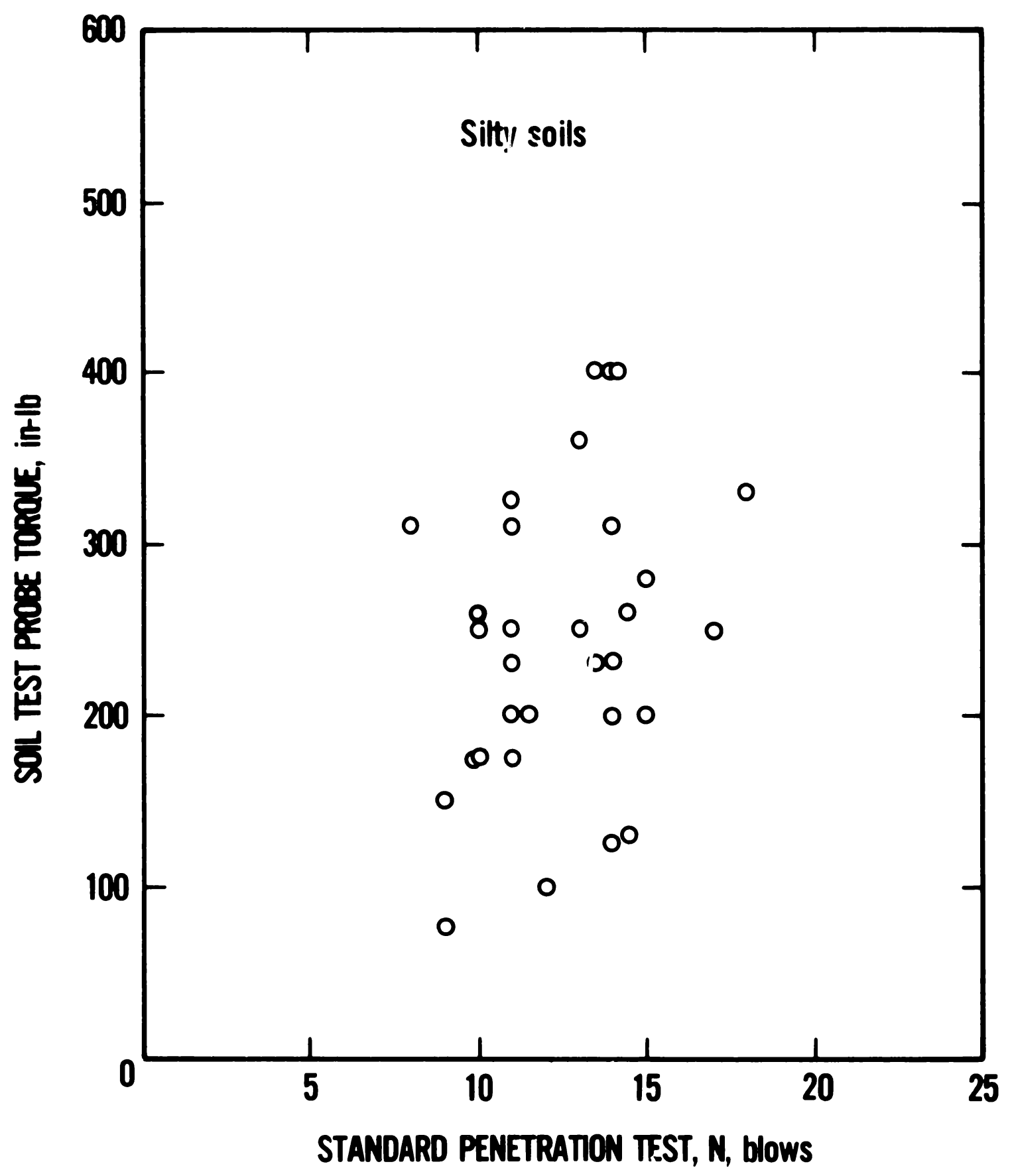

Figure 4.28 Correlation between SPT blowcount and STP torque readings for the silt site 
Since all anchors are $4 \mathrm{ft}$ or less, their strength is determined by the shear strength and unit welght of the soil between 0 and $4 \mathrm{ft}$ depth. As already noted, soll shear strength in this depth range varies rapidly with depth and is difficult to measure. This further complicates the problem of comparing the teist results with theoretical models.

Comparison of Test Results with Uplift Capacity Equations

(a) Cohesive Soils

All the full-depth anchors will be considered in this section, even though it appears that all the 4-in double hellx anchors (because of the upper hel1x) acted like shallow anchors, and the 6-in single helix anchors on the clay site may have been on the borderline between deep and shallow anchors.

The following equation was proposed to calculate the load capacity of anchors in cohesive solls [11]:

$$
Q_{u}=N_{u} C A+S
$$

where $A=$ projected anchor plate area

$c=$ cohesive strength of soll

$\mathrm{N}_{\mathrm{u}}=$ an uplift capacity factor

$S=$ resistance of anchor shaft

$S$ is assumed to be very small and therefore can be neglected. Strictly speaking, only the clay on Site $C$ would act like a cohesive soll. The silt derives only part of its shear strength from cohesion (or apparent cohesion). The other part would be attributed to frictional resistance. However, due to the fact that the deepest anchors are only $4 \mathrm{ft}$ deep the confining pressures and thus the frictional resistance should be small. This is further corroborated by the characteristics of the depth vs. shear strength profile evident from the STP readings and by the great ductility of the anchors tested in silt (confining pressures caused by overconsolidation would be relleved as the anchor is pulled out .)

The value of $\mathrm{N}_{\mathrm{u}}$ is generally assumed to increase with depth until the anchor is a deep anchor and then to remain essentially constant. Typical values proposed for $N_{u}$ are summarized by Davie and Sutherland [8, figure 7]. These values range from 5 to 10 and tend to become constant for D/B ratios gieater than 6 (3 ft depth for a 6-in single helix anchor).

Implicit in equation 4.11 with a constant value of $N_{u}$ is the assumption that for D/B ratios greater than 6 the anchor capacity should be essentially proportional to the area of the anchor plate (barring some shape factors related different plate geometries). In figure 4.29, the average load capactiy per unit area of anchor plate in psi is plotted against the size of the anchor plate in in $^{2}$ for the coaxial tests on full-depth vertical anchors and the tests on the self seating swivel anchors for the silt and the clay sites. These values 


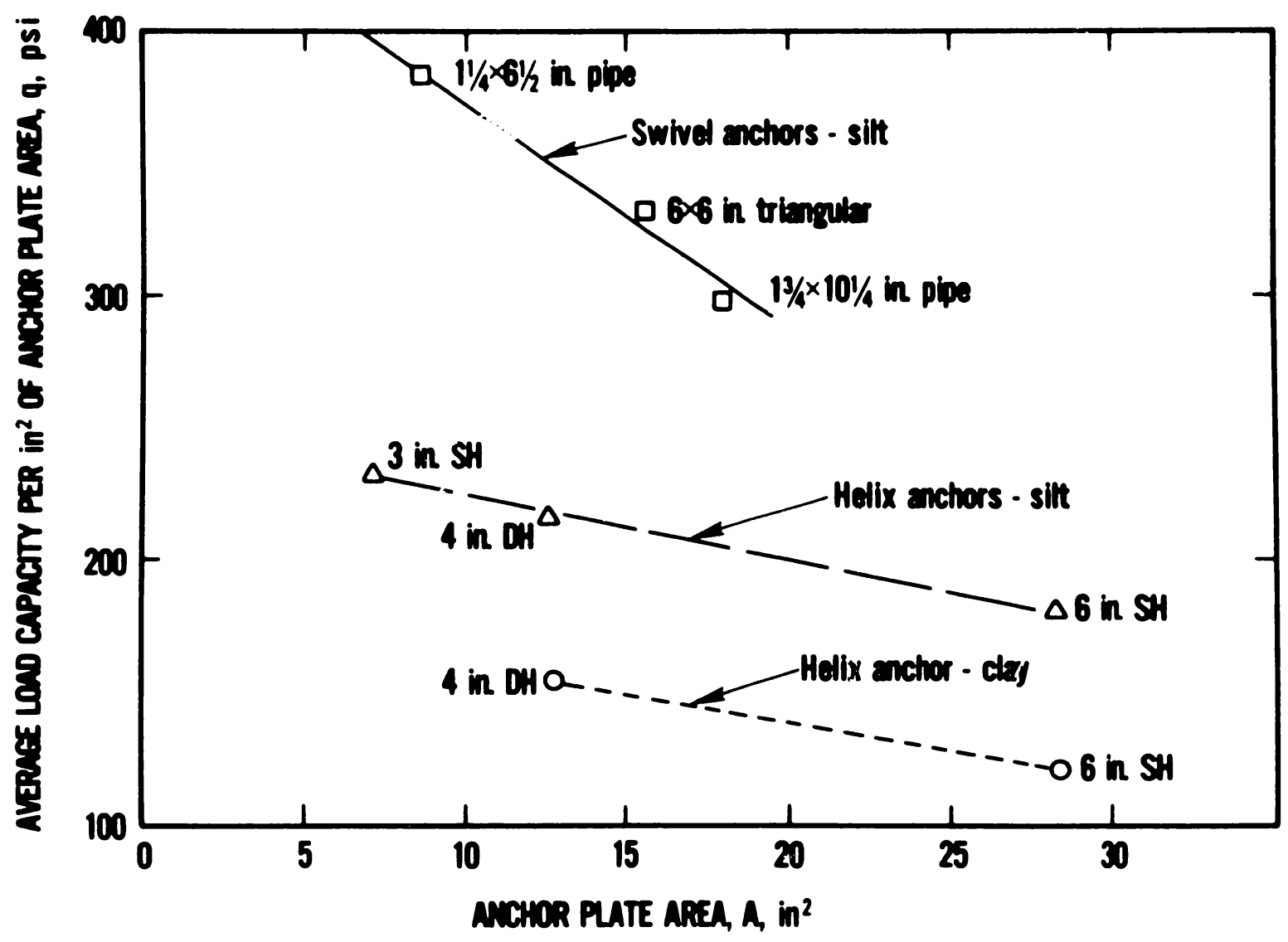

Figure 4.29 Effect of anchor plate size on $q$ in the silt and clay sites 
should he constant in accordance with accepted hypotheses. However, as can be seen from the figure, there is a consistent trend for q to increase with decreasing anchor-plate size. The trend is definitely not attributable to changer in the soll profile. The swivel anchors were all installed at the same depth of approximately 50 inches and had $D / B$ ratios of 8 or more. The smaller helix anchors were shallower than the larger cines. If anything, this should produce the opposite effect, since soll strength tended to inarease with depth. The fact that the 4-in double helix anchors acted like shallow anchors should also produce che opposite effect.

There is at this time no satisfactory explanation for the trend observed in figure 4.29. Similar trends have been observed by Tsangarides $|18|$, pg. 186, for anchors in sand. However, in that case, plate diameters were 2 in or smaller. Another interesting trend that can be derived from figure 4.29 is that the value of $\mathrm{N}_{\mathrm{u}}$ for the swivel anchors is greater than that for the helix anchors, and that the size effects for the swivel anchors are more pronounced.

Even though the shear strength of the soil changed with depth as well as location, it is of interest to trv to determine $N_{u}$ values for the anchors in the silt and cliy sites.

On the basis of the lahoratory tests, the $c$ value of the clay on Site $C$ is between 700 ( $U-U$ triaxial test) and 965 psf (unconfined compression test). Values calculated from the pullout tests of shallow anchors, using the simplifled cylindrical surface are 570 psf for the 1 and $2 \mathrm{ft}$ depths ( 6 in anchors), 720 psf for a $2.5 \mathrm{ft}$ depth ( 4 in anchors), and 620 psf for a $3 \mathrm{ft}$ depth ( 6 in anchors). These values are reasonably consistent with each other.

Baseid on 7001 psf shear strength in the 3 to $4 \mathrm{ft}$ depth range, the following $\mathrm{N}_{\mathrm{u}}$ values are calculated:

$\begin{array}{lll}\text { Anchor } C-6 & \mathrm{O}_{\mathrm{u}}=2800 & 1 \mathrm{~b} ., \mathrm{N}_{\mathrm{u}}=20 \\ \text { Anchor } \mathrm{C}-7 & \mathrm{O}_{\mathrm{u}}=3800 & \mathrm{lb} ., \mathrm{N}_{\mathrm{u}}=28 \\ \text { Anchor } \mathrm{C}-8 & \mathrm{O}_{\mathrm{u}}=3650 \mathrm{lb} ., \mathrm{N}_{\mathrm{u}} 27\end{array}$

These values of $\mathrm{N}_{\mathrm{u}}$, as well as the trend for $\mathrm{N}_{\mathrm{u}}$ to increase with decreasing anchor plate area are not consistent with accepted anchor capacity hypotheses. There are two factors which may have increased anchor capacity: suction effects (negative porewater pressures) associated with the large pullout displacements and which did not dissipate during the test because of the low permeability of the clay (such effects have been observed by others 11]); and root systems in the soil.

For the silt site, the laboratory test results are not as consistent as those for the clay site. The unconfined compressive strength was $4000 \mathrm{psf}$, which would indicate a shear strength of $2000 \mathrm{psf}$. Shear strengths obtained from direct shear tests ranged from 400 to 800 psf. Lower bound shear strengths calculated from the pullout tests, using a cylindrical fallure surface ranged 
from 430 to $1200 \mathrm{psf}$. Thus, it may be misleading to use any one value. Therefore, $N_{u}$ is calculated in two ways:

1. Using 2000 psf on the basis of the unconfined compressior test; and

2. Using a value of $s=6.4 t$ for tests where $t$ was measured.

The following results are obtained:

Using test probe readings:

The average value of $\mathrm{N}_{\mathrm{u}}$ for the 6-in single helix anchors is 19 with a coefficient of variation of 0.2 .

Using s $=2000$ psf:

The average value of $\mathrm{N}_{\mathrm{u}}$ for the 6-in single helix anchors 181.2 .6 with a coefficient of variation of 0.09 . The average value of $N_{u}$ for the $3-1 n$ single helix anchors is 16.8 with a coefficlent of variation of 0.17 and tre $\mathrm{N}_{\mathrm{u}}$ values for the swivel anchors are 27.9 for the $61 / 2-1 \mathrm{n}$ p1pe, 23.6 for the 6 in arrowhead and 20.5 for the 10-in pipe.

If a cylindri:al fallure surface is assumed to be the fallure mechanism 1t can be shown that

$$
N_{u}=4 D / B *
$$

$(\mathrm{eq} \cdot 4 \cdot 12)$

where $D / B^{*}$ is the $D / B$ ratio at which the fallure surface ceases to extend to the ground surface.

It has been previously shown that for the 6-in single helix anchors on the silt site the critical depth ${ }^{3 /}$ where the anchors cease to be shallow anchors is between $2.83 \mathrm{ft}$ and $3 \mathrm{ft}$ (see figure 4.13) thus $\mathrm{D} / \mathrm{B}^{*}$ is somewhat smaller than 5.5 , and $\mathrm{N}_{\mathrm{u}}$, calculated by eq. 4.12 would be somewhat less than 22 .

Note that the $\mathrm{N}_{\mathrm{u}}$ values for the silt site are not inconsistent with those obtained for the clay site. However, as in the case of the clay site, they are not consistent with hypotheses and data presented by others [8]. It should be noted, however, that in accordance with avallable data from engineering studies in the area the silt may have an angle of shearing resistance of as much as $30^{\circ}$, and thus the pullout capacity is not adequately predicted by eq. 4.11 .

3/ Actually the concept of a clear demarcation between "deep" and "shallcw" anchors has been questioned. Davie and Sutherland [8] distinguished three zones of $D / B$ ratios: shallow - $0<D / B \leq 2$; intermediate: $2<\mathrm{D} / \mathrm{B} \leq 4.5$; deep: $\mathrm{D} / \mathrm{B}>4.5$. 


\section{(b) Granular Solls}

Anchor capacity on the sandy site should be compared with the pullout capacity equation proposed for sands [11]:

$$
\eta_{\mathrm{u}}=r \mathrm{DN}_{\mathrm{qu}} \mathrm{A}
$$

where $\gamma=$ in-situ unit weight of soil

$D=$ depth of anchor. plate below surface

$\mathrm{N}_{\mathrm{qu}}=$ uplift capacity factor for granular material which is a function of the angle of sheaing resistance $(\phi)$ and the $D / B$ ratio.

The only "deep anchors" tested in sand were the 6-in single helix anchors. Thus size effect cannot be effectively explored. There is evidence [3] that $\mathrm{N}_{\text {qu }}$ increases with depth at least to a $\mathrm{D} / \mathrm{B}$ ratio of 14 . Thus, there is no sharp dividing line between "shallow" and "deep" anchors.

The $\mathrm{N}_{\mathrm{qu}}$ values calculated on the basis of the test results are given in table 4.11 (tests conducted in the area overlain by the hard crust were not considered):

Table 4.11 Uplift Capacity Factors for Full-depth Anchors on the Sandy Site

\begin{tabular}{|c|c|c|c|c|c|c|}
\hline Anchor Type & $D / B$ & Number & of Tests & $\begin{array}{l}\text { Range } \\
\text { of } \mathrm{N}_{\mathrm{qu}}\end{array}$ & (Average) & $\begin{array}{l}\text { Coefficient of } \\
\text { Variation of } \mathrm{N}_{\mathrm{qu}}\end{array}$ \\
\hline $1+6$ & 7.5 & & 5 & $74-84$ & 75.6 & 0.07 \\
\hline$D-4$ & 7.5 & & 3 & $71-84$ & 77.5 & 0.08 \\
\hline
\end{tabular}

The values in table 4.10 are quite consistent and the scatter is not very great. The $\mathrm{N}_{\mathrm{qu}}$ values are high compared with other avallable data [3] (A $\phi$ value of $31^{\circ}$ was used for the comparison). However, there is considerable scatter in the avallable data. The relatively high load capacity on the site is attributed to overconsolidation which increases the shear strength by increasing confining pressures (there was approximately $20 \mathrm{ft}$ overburden which was recently removed). The rapid loss of load capacity as anchors are pulled out is also attributed to overconsolidation.

$\mathrm{N}_{\mathrm{qu}}$ ratios were also calculated for the shallow anchor tests and are given in table 4.12. The values in table 4.11 can be compared with those for the fulldepth anchors. All the results are for 6-in single helix anchors on the sandy site. 
Table 4.12 Uplift Capacity Factors for 6-in Singie Helix Anchors Installed to Less Than Their Full Depth in the Sandy site

$\begin{array}{rlrrr}\text { Anchor Depth } & \text { D/B } & \text { No. of tests } & \text { Range of } N_{\text {qu }} & \text { Average } N_{\text {qu }} \\ 2 \mathrm{ft} & 4 & 2 & 48-61 & 5+ \\ 3 \mathrm{ft} & 6 & 2 & 72-88 & 80 \\ 3.75 \mathrm{ft} & 7.5 & 5 & 74-84 & 76\end{array}$

Unfortunately, there are not enough tests to determine whether the size effects observed on the silt and clay sites also occur in sands. However, the consistency of the $\mathrm{N}_{\mathrm{qu}}$ values when comparing the full-depth 6-in single helix and 4in double helix anchors indicates that there were probably no size effects for the anchors tested.

4.6.4 Determination of Load Capacity on the Basis of Pullout Tests in Similar
Conditions

The tests presented herein were performed on reasonably uriform sites.

Nevertheless, there were considerable variations in pullout strength on any one site. Much greater variations should be expected if an anchor is certified generically for some soll condition occurring over a larger region. The fulldepth vertical coaxial pullout test results are summarized in table 4.13 below for the three sites to give an overview of ti:e variability of test results encountered. All the numbers are for $Q_{u}$ in $1 \mathrm{~b}$.

Table 4.13 Range, Mean, and Coefficient of Variation of the Load Capacities of the Full-Depth Anchors

\begin{tabular}{|c|c|c|c|c|c|}
\hline S1te & Anchor Type & No. of & Range, $1 \mathrm{~b}$. & Mean, $1 \mathrm{~b}$. & $\begin{array}{c}\text { Coefficient of } \\
\text { Variation }\end{array}$ \\
\hline Silt & $\begin{array}{l}\text { H-6 } \\
D-4\end{array}$ & $\begin{array}{l}18 \\
12\end{array}$ & $\begin{array}{l}2800-6000 \\
1900-3200\end{array}$ & $\begin{array}{l}4740 \\
2700\end{array}$ & $\begin{array}{l}0.18 \\
0.18\end{array}$ \\
\hline Sand & $\begin{array}{l}H-6 \\
D-4\end{array}$ & $\begin{array}{r}10 \\
6\end{array}$ & $\begin{array}{l}.750-6825 \\
1530-3890\end{array}$ & $\begin{array}{l}5100 \\
2390\end{array}$ & $\begin{array}{l}0.23 \\
0.40\end{array}$ \\
\hline Clay & $\begin{array}{l}H-6 \\
D-4\end{array}$ & $\begin{array}{l}3 \\
3\end{array}$ & $\begin{array}{l}2800-3850 \\
1900-2000\end{array}$ & $\begin{array}{l}3430 \\
1930\end{array}$ & \\
\hline
\end{tabular}

Table 4.13 was compiled without regard to special local conditions such as the stiff crust covering part of the sand site and submerged areas, since such conditions should be expected to occur in practice. It can be seen that in most instances, even for one site which was considered uniform, there is considerabie 
strength variation. The effects of the strength variation were encountered during the cyclic tests on the clay site which was considered unifoim. Cyclic load levels were set in advance at what was thought to be 75 perrent of the load capacity as derived from adjacent static tests. However, in many instances the anchors falled before these load levels were reached. Typically, the coefficlent of variation for various test results tended to be about 0.2 . It can be seen that it increased to as much as 0.4 when local variations within the site are disregarded.

\subsubsection{Ef fect of Submerged Conditions}

The clay site was saturated, and therefore submerged conditions would not have had much effect on load capacity. On the other two sites, ef rects of submergence were explored. On the silt site, this was done in an area which was permanently under water. On the sandy site an area was temporarily submerged during some of the anchor tests. Results for the silty site are summarized in table 4.14.

Table 4.14 Comparison Between Regular and Submerged Anchor Tests on the Silty Site

\begin{tabular}{|c|c|c|c|c|c|}
\hline Anchor Type & Condition & No. of Tests & $\begin{array}{c}\text { Range } \\
\text { of } Q_{u}, 1 b\end{array}$ & $\begin{array}{l}\text { Average } \\
\mathrm{Q}_{\mathrm{u}}, 1 \mathrm{~b}\end{array}$ & $v$ \\
\hline $\begin{array}{l}+6 \\
+6\end{array}$ & $\begin{array}{l}\text { Unsubmerged } \\
\text { Sumberged }\end{array}$ & $\begin{array}{r}12 \\
6\end{array}$ & $\begin{array}{l}4200-6000 \\
2800-5700\end{array}$ & $\begin{array}{l}5090 \\
3980\end{array}$ & $\begin{array}{l}0.11 \\
0.25\end{array}$ \\
\hline $\begin{array}{l}D-4 \\
D-4\end{array}$ & $\begin{array}{l}\text { Unsubmerged } \\
\text { Sumberged }\end{array}$ & $\begin{array}{l}6 \\
6\end{array}$ & $\begin{array}{l}2250-3100 \\
1900-3200\end{array}$ & $\begin{array}{l}2730 \\
2660\end{array}$ & $\begin{array}{l}0.13 \\
0.29\end{array}$ \\
\hline $\begin{array}{l}+3 \\
+3\end{array}$ & $\begin{array}{l}\text { Unsubmerged } \\
\text { Submerged }\end{array}$ & $\begin{array}{l}5 \\
5\end{array}$ & $\begin{array}{l}1300-2050 \\
1000-2625\end{array}$ & $\begin{array}{l}1650 \\
1895\end{array}$ & $\begin{array}{l}0.17 \\
0.36\end{array}$ \\
\hline
\end{tabular}

It can be seen from the above summary that only the average strength of the 6-In single helix anchors was reduced by submergence. For all three anchor types, however, there was greater variation in the submerged test results and some individual submerged tests showed substantially reduced strength. It is suspected that the shear strength of the soll was actually reduced by submergence, but that some individual anchors had increased resistance because of the presence of some boulders in this area, and also possibly because of suction effects resisting the pullout. 
The submergence tests $I n$ the sand did not result in strength reduction because it was impossible to submerge a large enough area to eliminate seepage forces (piezometric heads at anchor plate elevation extended only $0.5 \mathrm{ft}$ above the anchor plate).

It is assumed that submergence should substantially reduce the resistance of anchors in granular soil, but that it does not necessarily affect the cohesive strength. However, no consistent trend emerges from the test data presented herein.

\subsection{CYCLIC TESTS}

\subsubsection{Cyclic Tests on the Silt Site}

Typical test results are shown in figure 4.30. Specimen ST111 was loaded to what was estimated to be $0.75 \mathrm{Q}_{u}$. Note that most of the displacement took place in the first load cycle and no further residual displacement occurred after 100 load cycles. This phenomenon is the result of gradual compaction causing the displacement to be entirely elastic after 100 load cycles. Similar load-displacement curves resulted at 50 and 25 percent of the estimated pullout load (tests ST116 and 118). Specimen ST123 was preloaded to $0.84 Q_{u}$ and subsequent load cycles were applied at $0.67 Q_{u}$. Note that $Q_{u}$ was overestimated for his specimen, resulting in a preload which was, close or equal to the ultimate load (the pullout load after cyclic loading, $Q_{u}$, was less than the preload). Nevertheless, the total displacement after 200 cycles was only 1.2 in. However, unlike in the other tests plotted, the preloaded specimen had small residual displacements for each load cycle up to 200 cycles. The tests on the silt site also included two tests on preloaded 4-inch double helix anchors. These tests had no further residual displacements after 100 load cycles.

It is of interest to consider whether the load capacity of the anchors was diminished as a result of the cyclic loading. The five 6-inch single helix anchors which were subjected to high cyclic load $\left(0.75 Q_{u}\right.$ vs $\left.0.67 Q_{u}\right)$ had an averged pullout strength $Q_{u}=5240 \mathrm{lb}$. with a coefficient of variation $\mathbf{v}=0.09$. This compares with an average pullout strength of $50901 \mathrm{~b}$ and $\mathbf{v}=.11$ for the anchors which were not subjected to cyclic load. Thus loading of up to 300 cycles of $0.75 \mathrm{Q}_{u}$ apparently had no significant effect on the pullout strength of the anchors. Indeed some of the anchors were subjected to cyclic loads as high as $0.9 Q_{u}$, since the actual pullout strength was not known when the cyclic load was applied (specimen ST123 was probably preloaded to ultimate and thereby weakened).

The total cumulative displacement of the preloaded anchors was well within limits acceptable in present standards (see section 4.8 ).

\subsubsection{Cyclic Tests on the Sandy Site}

Typical test results from the sandy site are shown in figure 4.31. Tests SD34 and SD35 are unpreloaded and preloaded axial tests, and tests SD38 and SD40 are 


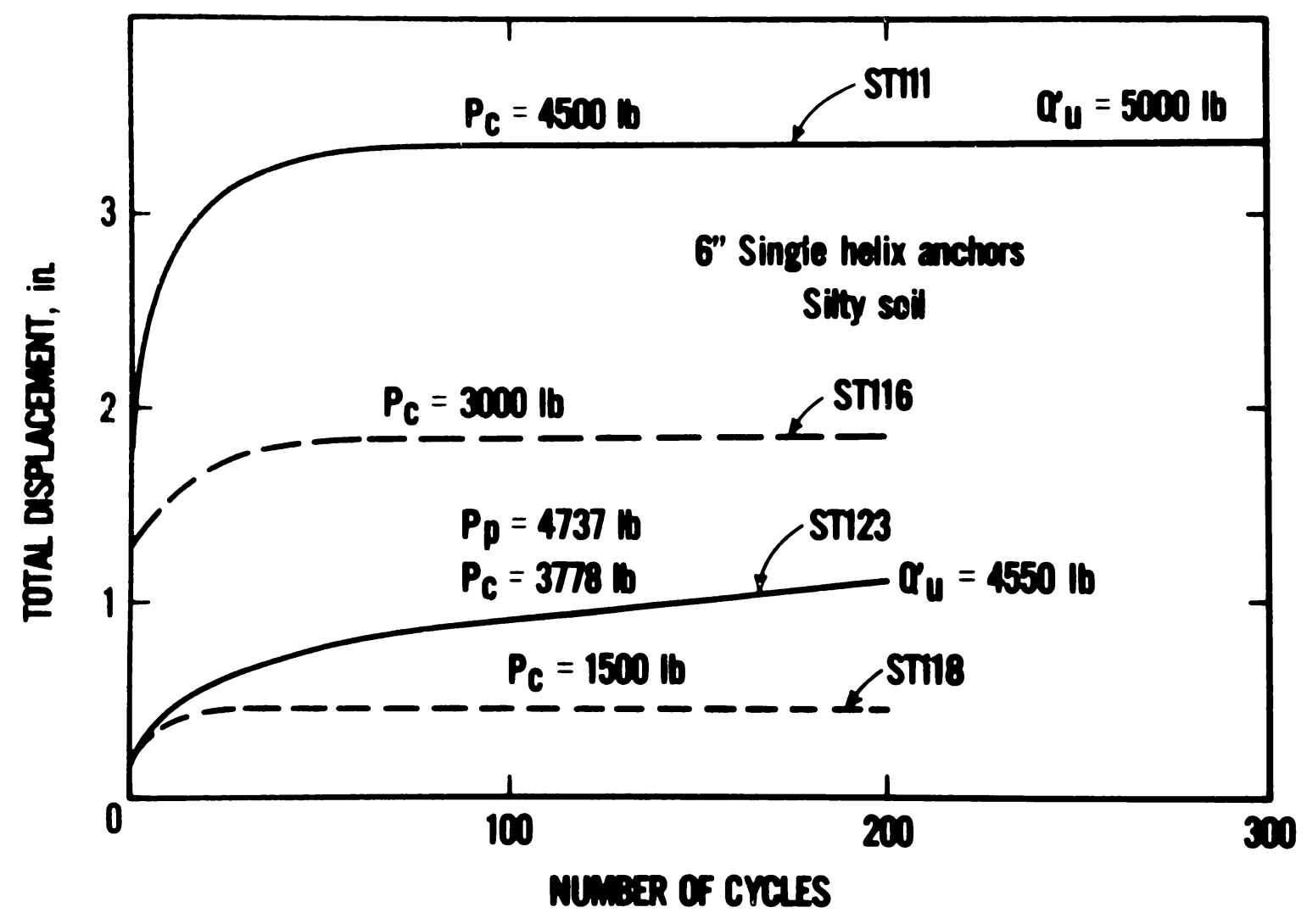

Figure 4.30 Cyclic load tests in silty soils 


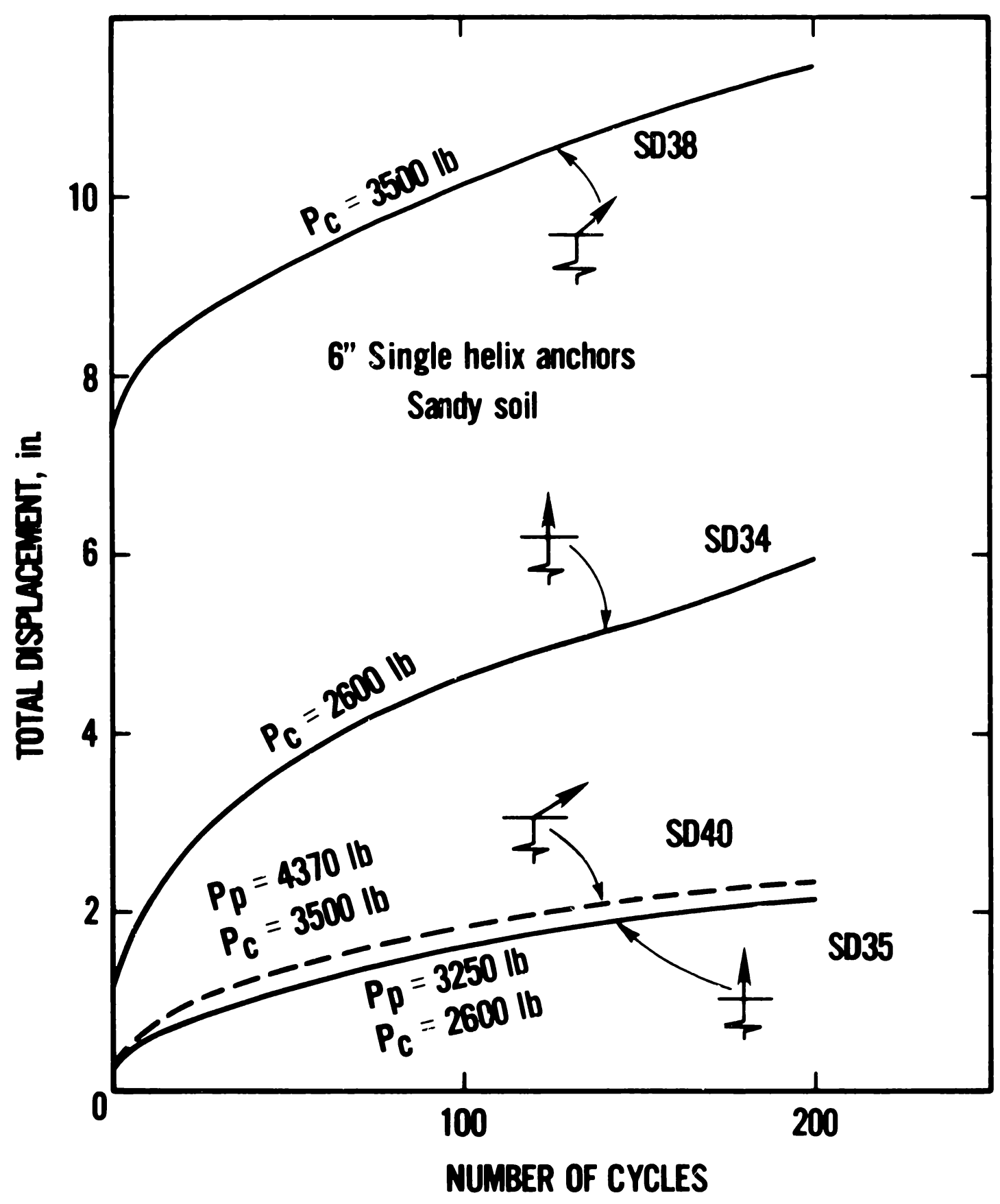

Figure 4.31 Cyclic load tests in sandy soils 
unpreloaded and preloaded tests on vertical anchors pulled at $40^{\circ}$ to the horizontal. Note that on the sandy site there was also some compaction effect, but there were small residual displacements in each load cycle up to the 200 load cycles applied in the test. The total cumulative displacement of the preloaded specimens after 200 load cycles of $2 / 3$ the ultimate load was approximately 2 in. If the assumption 18 made that $2 / 3$ of ultimate would be the maximum design load that can be reasonably permitted, and when the effect of these 200 cycles is compared with the hurricane history described in section $3.3 .2(4)$, and the design load is compared with the "maximum" wind load, it is conservatively estimated that a similar hurricane would have resulted in a cumulative anchor head displacement for preloaded anchors of not more than 1 inch (see also section $4 \cdot 7 \cdot 3$ ).

The effect of cyclic loading on anchor-load capacity is somewhat difficult to assess from the test data. For the vertical tests, four 6-inch single helix anchors had an average fallure load $Q_{u}$ of $46751 \mathrm{~b}$. with $v=0.07$. This compares with $Q_{u}=5290$ with $v=0.08$ for the sand site if submefged tests are excluded. For the 4-inch double helix anchors, the average $Q_{u}$ was $23251 \mathrm{~b}$. This compares with $23901 \mathrm{~b}$. with $v=0.4$ for all the tests in sand, but only $1610 \mathrm{lb}$. with $v=0.08$ if tests if the area of the dense crust are excluded. Thus no conclusive trend emerges from these tests.

Many of the inclined tests, when pulled out after cyclic loading failed by hardware fallure rather than pullout (helixes broke off). The loads resisted before hardware fallure tended to exceed the average static load capacity under this type of loading. Only in test SD13 was there a pullout as a result of strength deterioration by cyclic loading. The overall conclusion that can be drawn 18 that 200 cycles of $2 / 3$ of the ultimate load are not likely to cause progressive anchor fallure in elther of the two loading modes used or to substantially weaken load capacity. However the anchor hardware will be weakened by the cyclic load in the inclined loading mode, and progressive soll fallure could occur if the applied cyclic load approaches the load capacity of the anchors.

\subsubsection{Cyclic Tests on the Clay Site}

Typical test results are shown in figure 4.32. Specimens C24 and C25 are vertical anchors coaxially loaded to what was thought to be $0.75 Q_{u}$. Both anchors experienced progressive fallure. Specimen C26 is a preloaded specimen which performed well. However, its companion specimen, C27 (not shown) which was similarly preloaded, experienced progressive fallure. An examination of the preloading curves of specimens C26 and C27, shown in figure 4.33, indicates that C27 experienced ylelding during preloading. Thus the preload was very close to the ultimate load.

It is interesting to note, when comparing tests C25 and C26, that on the clay site the preloading effect did not occur in the initial load cycle, but rather tended to be gradual. This is attributed to the fast rate at which the cyclic load was applied. This loading rate did not permit enough time for the full 


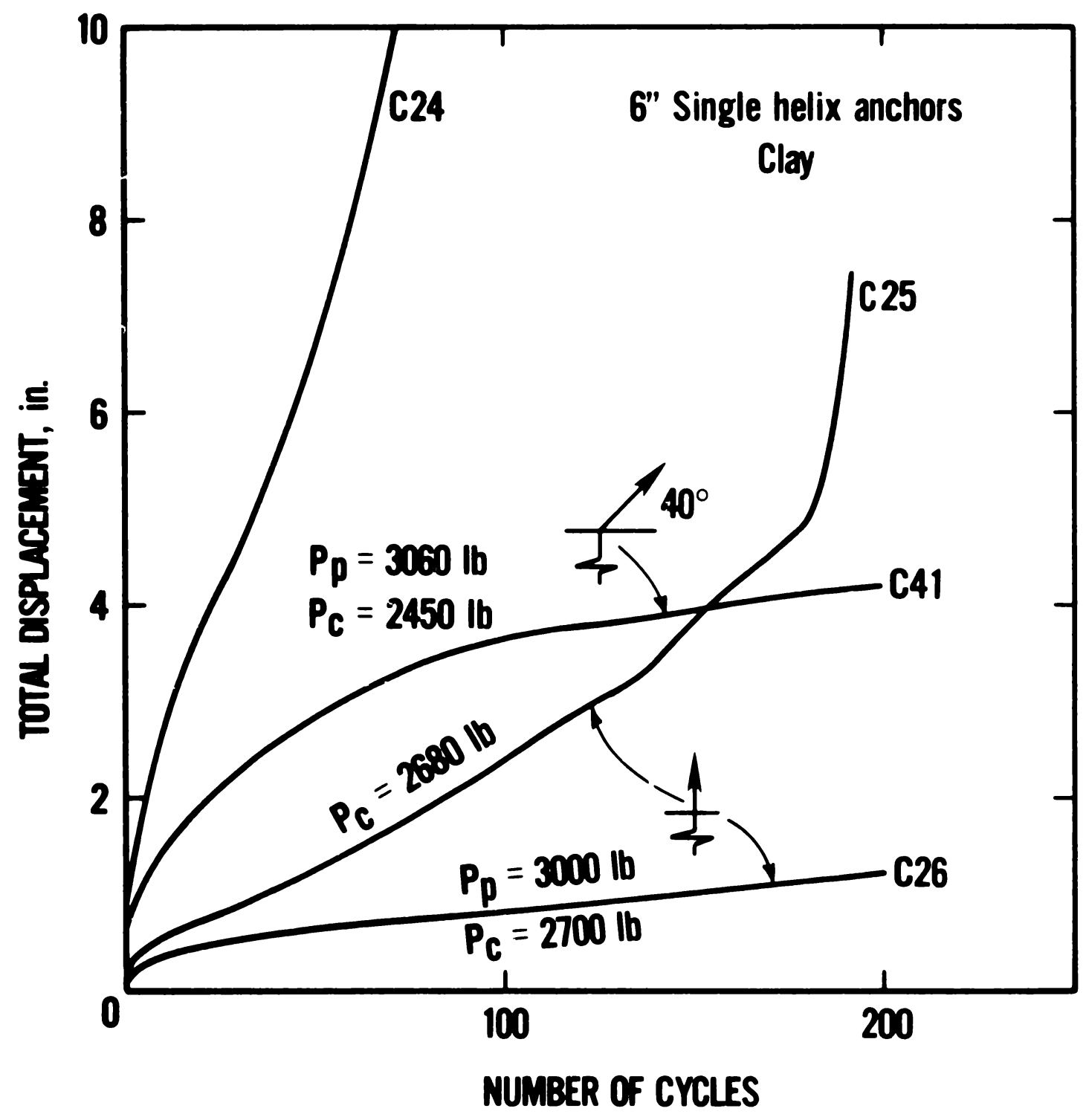

Figure 4.32 Cyclic load tests in clay 


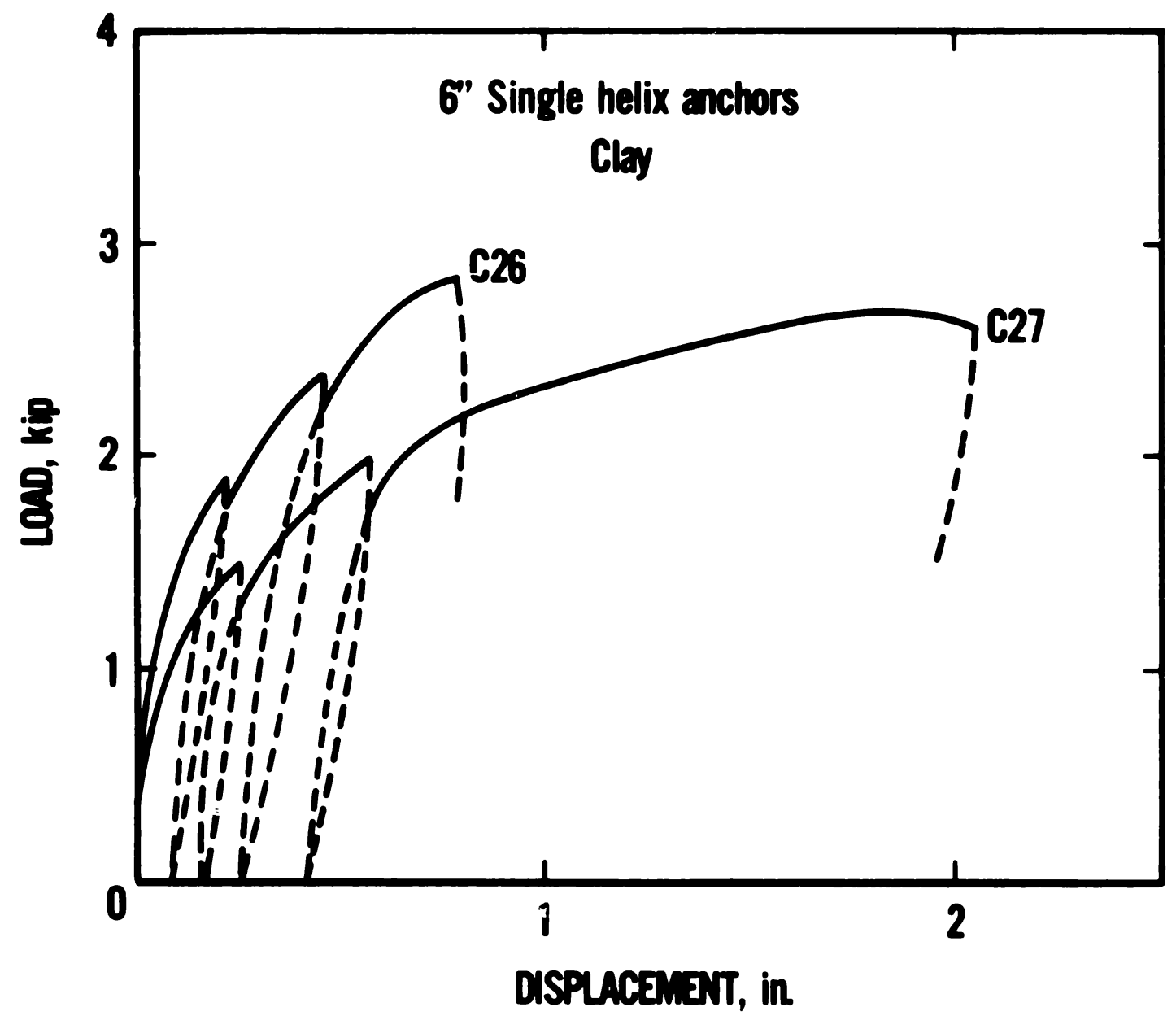

Figure 4.33 Comparison of the preloading curves of tests C26 and C27 
displacement to occur in the first few load cycles. The load, rather than being resisted by the soll skeleton, induced porewater pressure gradients. The displacement occured gradually over many load cycles as these porewater pressure gradients dissipated.

Curve C41 in figure 4.32 is for a preloaded vertical anchor subjected to inclined pull. Note that, even though this specimen was preloaded, it experienced a movement of 4 inches during the 200 applied load cycles. Some of the anchors in clay failed before reaching 200 load cycles. Of eight 6-in single helix anchors, four falled before reaching 200 load cycles. If we divide these into preloaded and unpreloaded anchors, 3 of 4 unpreloaded, and 1 of 4 pre'oaded anchors falled. Of the eight 4-in double helix anhors tested, two of the four unpreloaded anchors and none of the four preloaded anchors failed.

Anchor C33, a 4-inch double helix, was loaded to 450 cycles in order to ascertain whether failure could be induced in anchors which perform satisfactorily for 200 load cycles. The results of test C33 are plotted in figure 4.34. Note that in the 10 to 200 cycle range the creep increment per cycle was about constant. After 200 cycles, the specimen deteriorated and fallure occurred at 450 cycles. From the preloading curve, it appears that this specimen was loaded to 80 percent rather than 67 percent of ultimate. It is reasonable to assume that at these high cyclic loads all specimens would fail if enough load cycles are applied.

It is difficult to determine whether the load capacities of the specimens which did not fall were impaired by the application of 200 load cycles, since all the weaker specimens falled. Perhaps the best information can be derived from the coaxially-tested 4-in double helix anchors, which all survived the cyclic test (except that the test on anchor C33 was continued for 450 cycles unt 11 fallure occurred). The three anchors tested had an average $Q_{u}$ of $20671 \mathrm{~b}$ This compares with an average load capacity of $1930 \mathrm{lb}$ for the anchors tested statically. Since the variability of these test results is very small ( $v=0.07$ for the cyclic tests, and 0.03 for the static tests), this is taken as an Indication that the load capacity of the anchors was not significantly affected by the cyclic tests.

The question should be asked whether cumulative displacement caused by windload effects would be within tolerable limits. Looking at the wind data in section 3.3.3(4) and assuming that increments of displacement would be approximately proportional to increments of load and that the cyclic load applied is equal to the design load, and thus the maximum windload experienced in the storm, the storm would cause a cumulative displacement of less than 100 cycles of the design load (this is a very conservative estimate). This would result in a cumulative displacement of $31 / 2$ inches for anchor $C 41$ and of less than 1 inch for anchor C26. Even though these displacements are considerable, they are not considered excessive for the extreme conditions assumed.

It is of interest to compare the anchor performance under cyclic load at the clay site with the results of other studies of the cyclic shear strength of 


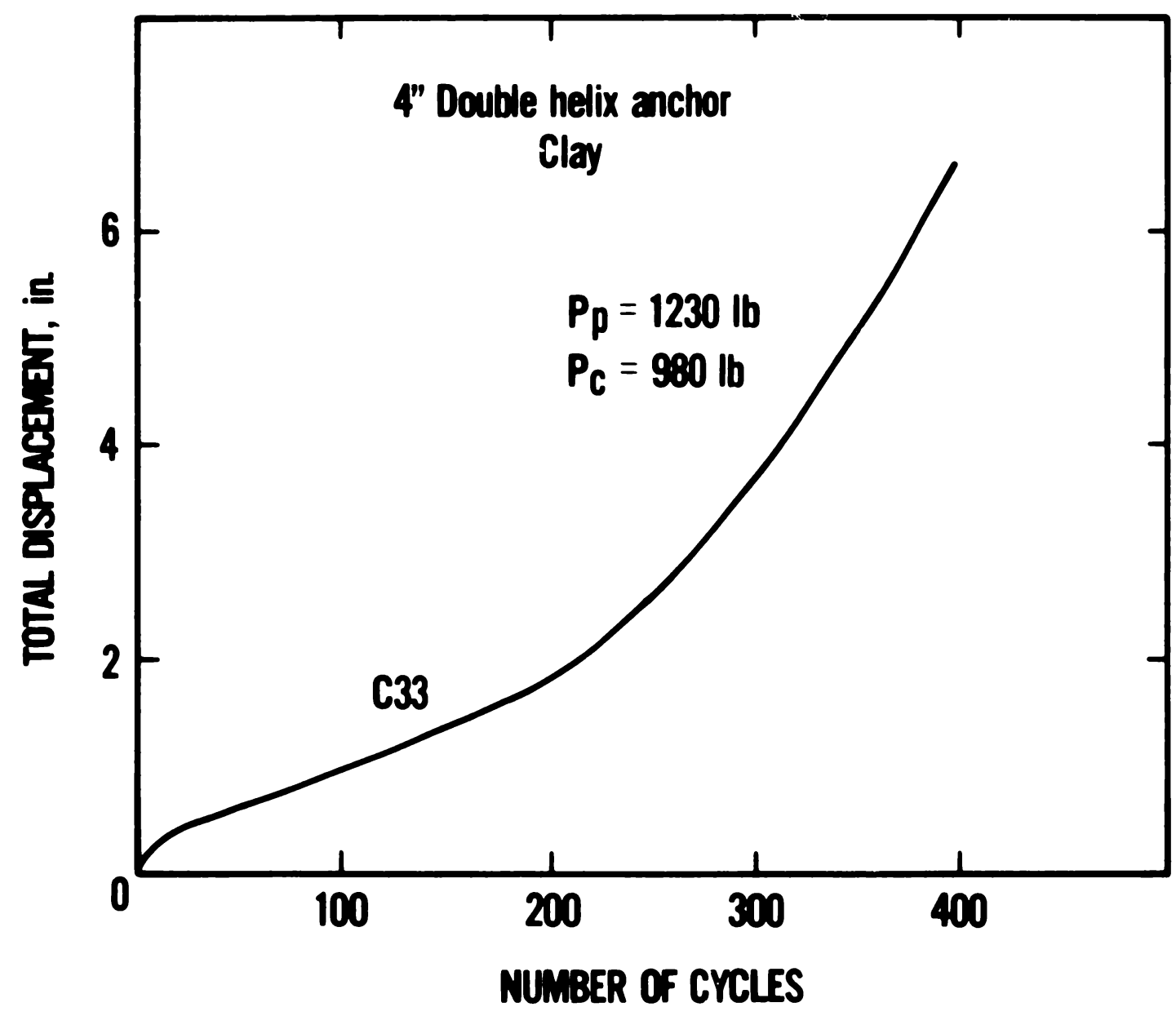

Figure 4.34 Results of the cyclic loading test of specimen C33 on the clay site 
clays. Seed and Chan [16] studled three different clay types and found that, for loading conditions simllar to those of the anchor tests (no shear stress reversals) the shear strength under 100 load cycles varied from 70 percent of the static shear strength for a soft sensitive clay to 80 percent of the static shear strength for compacted sandy clays. These findings are compatible with the results of this study and give further corroborations to the fiding that anchors in clays can survive 100 cycles of 67 percent of their fallure load without fallure.

\subsection{COMPARISON OF ANCHOR PERFORMANCE WITH PRESENT STANDARD REQUIREMENTS}

ANSI Standard Al19.3 [2] requires that anchors resist a load of 4725 lb without fallure, where fallure $1 \mathrm{~s}$ defined as a 2-1nch displacement of the anchor head in the vertical direction or a 4-inch displacement in the horizontal direction. The HUD Mobile Home Construction and Safety Standard [9] sets even more conservative requirements by stipulating that loads be increased by 50 percent for the design of foundations. Hereafter these requirements are compared with the test results.

On the Silt Site (refers to table B.1), $P_{2 v}$ for the vertical full-depth 6-1nch . Ingle helix anchors ranged from $3000 \mathrm{lb}$ to $5750 \mathrm{lb}$ and averaged at $42701 \mathrm{~b}$ with $v=0.19$. The average, as well as the lowest strength, are lower if the submerged tests are considered. The resistance of the diagonally loaded vert1cal anchors at 4-inch horizontal displacement and $45^{\circ}$ pull ranged from 1100 to $1.300 \mathrm{lb}$ and averaged $1260 \mathrm{lb}$ wth $\mathrm{v}=0.16$. The values for the 4-1nch double helix and the swivel anchors are not listed here since they fall far short of required capacities.

On the Sandy S1te (refers to table B.3), $P_{2 v}$ for the vertical full-depth 6-1nch single helix anchors ranged from $3900 \mathrm{lb}$ to $6000 \mathrm{lb}$ and averaged $4800 \mathrm{lb}$ with $v=0.13$. The resistance of the diagonally loaded vertical anchors at 4-1nch horizontal displacement and $40^{\circ}$ load inclination ranged from 2800 to $40001 \mathrm{~b}$ and averaged $3200 \mathrm{lb}$.

On the Clay Site (refers to table B.5), $P_{2 v}$ for the vertical full-depth 6-1nch single helix anchors ranged from $2300 \mathrm{lb}$ to $3500 \mathrm{lb}$ and averaged $3100 \mathrm{1b}$. The resistance of the diagonally loaded anchors at 4-inch horizontal displacement was negligible.

Thus, even though the sites selected were competent sites, anchor capacity fell far short of present standard requirements. Even on the sandy site, where anchors were relatively 8 iff and the average performance of the vertical anchors met standard requirements, many individual anchors did not meet the requirements. Not a single diagonally loaded specimen met the standard requirements.

It can be conciuded from the test results that presently used anchor technology with present Installation procedures did not deliver the performance required by ANSI Standard Al19.3. 


\subsection{PERFORMANCE OF ANC HOR HARDWARE}

In coaxial pullout, there were relatively few anchor hardware fallures at loads lower than the stipulated 4725 lb capacity. In four instances, anchors failed below the 4725 load level, always by a break in the weld which connects the helix to the shaft. Two of the four fallures occurred in cyclic tests. Many of the noncoaxially tested specimens falled because of anchor hardware fallure. But these fallures occurred at very high load levels and were in part caused by the fact that the soll resistance was extremely high.

Most anchors withdrawn had bent helixes (mushroom shaped). While the bending of the helix did not cause anchor fallure, it may well have reduced the load capacity of the anchors and increased displacements. Almost all the anchors withdrawn had their paint stripped off. The paint stripping probably occurred during insertion. Thus it is concluded that painting does not provide effective corrosion protection. In the anchors which were subjected to non-coaxial pull, the anchor shaft was severely bent (see figure 4.7). Figure 4.35 shows typical anchor hardware failures.

The conclusions that can be drawn from the anchor hardware performance are that anchors should e galvanized or otherwise effectively protected against corrosion. The corrosion protection should not be damaged by installation and remain effective where yielding occurs during anchor installation or loading, 1.e., on the anchor shaft and the helix. Another conclusion that can be drawn is that the load capacity of anchors could probably be Improved by using a thicker helix plate that does not bend during withdrawal, and that during fabrication care should be exercised to insure the integrity of the weld between the anchor shaft and the helix plate. 
FACING PAGE: The "Soel Tesi Prube" used to predict anchorl'ad capacity is also a potentially use ful device for the in-situ measurement of the shear strength ch soils at a shallow depth.

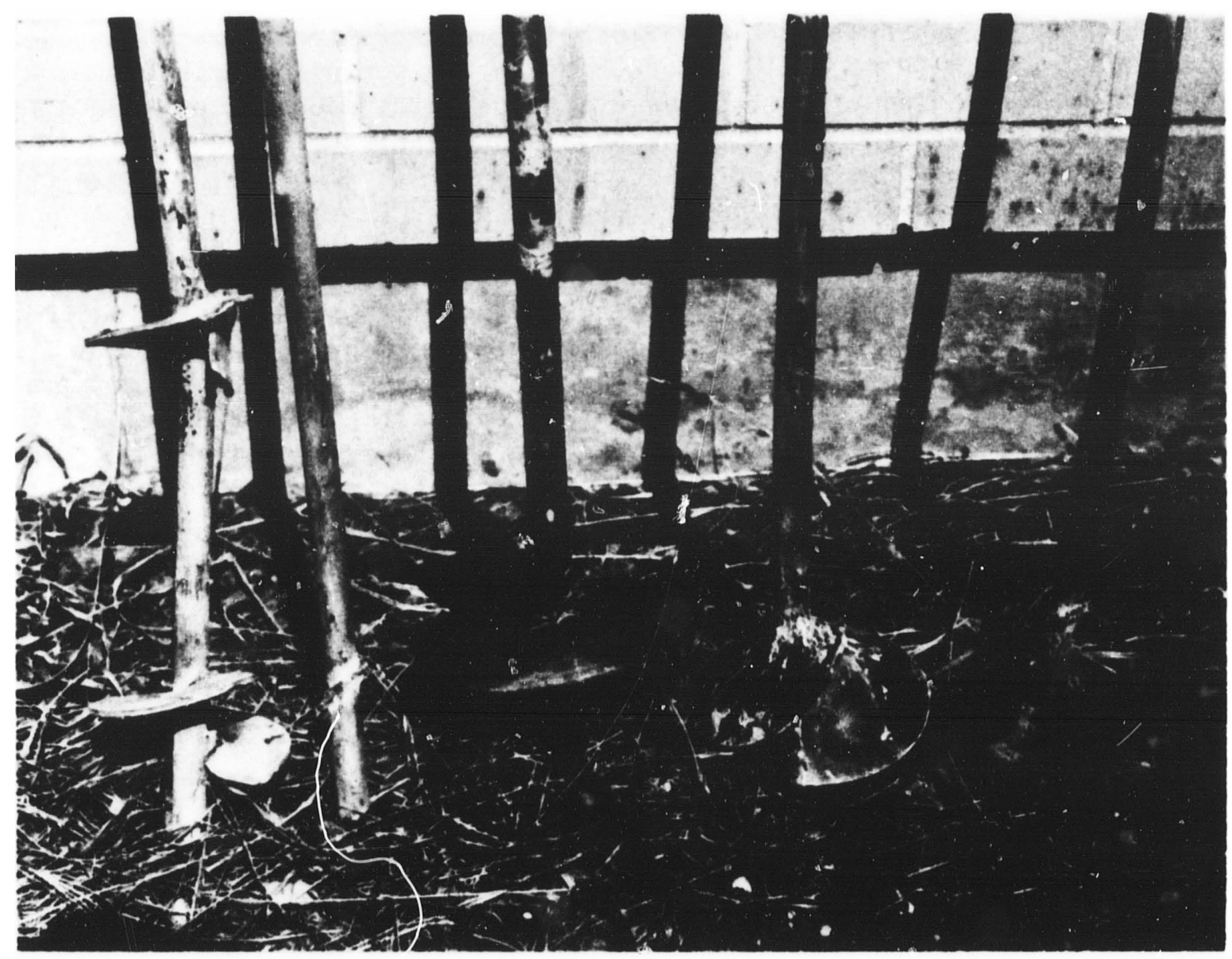

Figure 4.35 Typical anchor hardware fallures 


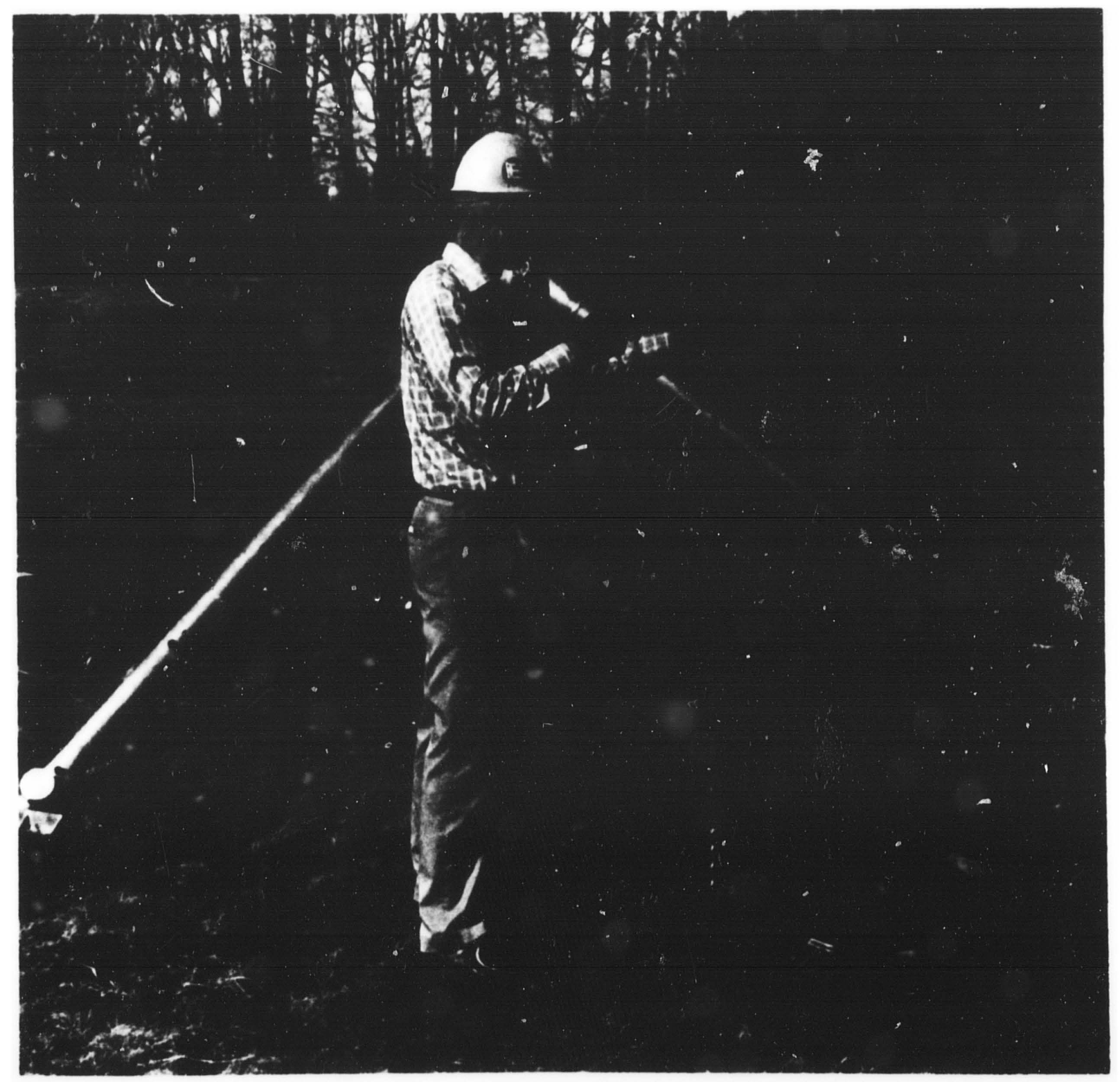

5. SUMMARY OF CONCLUS IONS

\subsection{GENERAL}

The findings presented herein are based on tests conducted in this project. Since soil is not a man-made material, the anchor behavior observed is not necessarily characteristic for all the sites that will be encountered in practice. 


\subsection{VIRGIN LOAD-DISPLACEMENT CURVES}

All anchors tested had a unique virgin load-displacement curve which depended on the characteristics, Installation depth and loading mode of the anchor and the 8011 conditions. The virgin load-displacement curve is a strength envelope which can not be changed by a limited number of intermediate unloading and reloading cycles, except that each unloading and reloading cycle will result in a small residual displacement. However, if a great number of intermediate load cycles was applied at a load level close to the pullout strength of the anchor they did in some Instances cause incremental failure on the sand and the clay site. The virgin load-displacement curves observed were a unique function of the installation depth of the anchor. For instance, if an anchor is installed at the depth of $3 \mathrm{ft}$ and withdrawn to the depth of $2.5 \mathrm{ft}$, unloaded and subsequently withdrawn, its load-displacement curve during withdrawal will differ from that of an anchor which is inttially installed to a $2.5 \mathrm{ft}$ depth and then withdrawn.

\subsection{RELOADING CHARACTER ISTICS}

When an anchor is loaded to a certain load level and then unloaded and reloaded, the secant reloading modulus (reload/displacement caused by reload) will be several times larger (stiffer) than the secant modulus of the virgin loading curve. Thus, a preloaded anchor will have much more favorable load-displacement characteristics than an anchor which is loaded for the first time.

\subsection{EFTECTS OR LOADING CONT IGURATION}

Helix anchors installed vertically and pulled at an angle had a virgin loaddisplacement curve which exhibited much less stiffness than that of coaxially loaded anchors. However, the reloading characteristics of these anchors were suparior to those required in present standards, even though they were adversely affected by elastic rebound of the anchor shaft. Helix anchors installed at an angle and withdrawn coaxially developed less load capacity than anchors Installed vertically and pulled coaxially. The load capacity of coaxially loaded inclined anchors was roughly equal to that of coaxially loaded vertical anchors installed at the same hellx depth below the ground surface (the difference in load capacity reflected the difference in embedment depth).

Vertically-installed hellx anchors pulled at an angle to the vertical developed higher load capacities than coaxially loaded vertical anchors. Their load capacity increased as the angle of withdrawal with the horizontal was decreased. However, their resistance to displacement in the inftial loading stages was very low.

Inclined hellx anchors loaded at a $90^{\circ}$ angle to the shaft had very low load capacities and low resistance to displacement.

Swivel anchors pulled at an angle to the vertical had elther the same load capacity as vertically-pulled anchors (triangul - anchors) or their load 
capacities decreased with a decrease of the angle of pull with the horizontal (pipe anchors).

\subsection{EFFECTS OF SOIL TYPE}

Anchors installed in the silt site had considerable ductility. (They could be withdrawn for a relatively large distance without a reduction in load capacity.) Anchors installed in clay had also considerable ductility, but their load capacity reached a peak and gradually decreased as they were further witindrawn. Anchors installed on the sand site lost their load capacity abruptly upon further withdrawal after their peak load capacity was reached.

5.6 PREDICTION OF ANCHOR LOAD CAPACITY BY IN-SITU TESTS

(1) Soil Test Probe

Soil Test Probe readings did correlate with anchor capacities, except that on the clay site some of the Test-Probe readings were abnormally low, apparently because of porewater pressure buildup. The capacity of the 6-inch single helix anchors can be reasonably correlated with Test Probe readings where the tip of the test probe was near the helix. The capacity of the 4-inch double helix anchors can be reasonably correlated with the average test probe reading over the depth of the anchor. There appears to be a good correlation between the in-situ shear strength of the soil and the test probe reading on the sand and the silt site. The results from the clay site were erratic.

\section{(2) Installation Torque}

It appears that it is possible to determine a lower bound for anchor pullout capacity from measurements of the installation torque at maximum penetration. However, the scatter of the data is considerable and the lower-bound prediction is too conservative to be of practical value.

\section{(3) Standard Penetration Test}

It does not appear that the Standard Penetration Test is a useful tool for predicting the strength of shallow anchors, mainly because of the short drill stem length used in shallow depths.

\subsection{THEORETICAL PREDICTION OF ANCHOR-LOAD CAPACITY}

Theoretical prediction of anchor-load capacity can only be as good as the estimate of the in-situ shear strength of the soil. Since in-situ shear strength at shallow depths is difficult to determine, the practical applicability of theoretical models is limited.

Correlation of the test results on the silt and clay sites with presently used theoretical pullout capacity models was poor. It was observed that anchor capacity per unit area of anchor plate increases as the anchor-plate area 
decreases. It was also observed that the swivel anchors have a higher load caparity per anchor-plate area than the helix anchors. In general, anchor load capacities were much higher than those that would be predicted on the basis of existing theoretical models and available data on soil-strength characteristics.

Correlation of the test results on the sandy site with presently used theoretical models was poor because the sand was overconsolidated and possibly cemented. Effects of depth and anchor plate size were similar to those predicted by theoretical models, but the anchor capacities were much higher than those that would be calculated on the basis of available data on soil-strength characteristics.

5.8 PREDICTION OF ANCHOR LOAD CAPACITIES ON THE BASIS OF TEST ON SIMILAR SITES

The coefficient of variation of anchor strength on the sites ranged from 0.18 to 0.40 . There probably would be more variation if anchor test results from one site are used to predict anchor strength at another site.

5.9 ANCHORS SUBJECTED TO CYCLIC LOAD

On the silt site, anchors tended to stabilize after 100 load cycles and additional cycles caused no further creep. On the sand and clay site, creep displacement continued inciefinitely and failure could be induced if enough load cycles are applied. Failure actually occurred in some specimen where the applied cyclic load was close to the anchor load capacity.

The cyclic-load performance of anchors, preloaded to a load higher than the applied cyclic load was superior to the performance of unpreloaded anchors. There was no evidence that the pullout strength of anchors was reduced by applying 200 cycles of about $2 / 3$ of their pullout strength.

It appears that on all three sites anchors could survive the effects of a major hurricane with displacements smaller than those permitted in the present ANSI Standard (2-inch vertical and 4-inch horizontal), provided that the maximum wind load effect does not exceed $2 / 3$ of the pullout strength of the anchor and the anchors are preloaded.

5.10 COMPARISON OF ANCHOR PERFORMANCE WITH PRESENT STANDARD REQUIREMENTS

Presently-used anchoring technology did not provide the anchor performance required by ANSI Standard Al19.3, neither in terms of load capacity, nor in terms of load-displacement characteristics.

\subsection{PERFORMANCE OF ANC HOR HARDWARE}

Anchor hardware generally developed the required load resistance. After Installation, painted anchors do not seem to have effective corrosion protection because of paint stripping. Most anchor helixes were bent after anchor 
withdrawal, Indicating that anchor performance could probably be improved by thicker helix plates.

The shafts of anchors installed vertically and withdrawn at an angle were severely bent before the anchors reached their maximum load capacity.

Most anrhor hardware fallures occurred by a fallure of the weld between the shaft and the hellx plate. Some of these fallures were Induced by cyclic loading.

\subsection{USE OF SOIL ANCHORS IN PERMANENT MOBILF HOME FOUNDATIONS}

The possibility of using anchors in permanent moblle home foundations has recently recelved some consideration.

It is evident from the test results, that if anchors are to be included as part of a permanent foundation they must have adequate corrosion protection to retain their structural integrity throughout the service ilfe of the mobile home and they should be preloaded to insure adequate performance under anticipated extreme loads.

Such anchors would also have to be adequately protected against otential effects of frost heave. 
FACING PÁGE: Pullout test of submerged anchor installed in swail crossing Site $B$. 


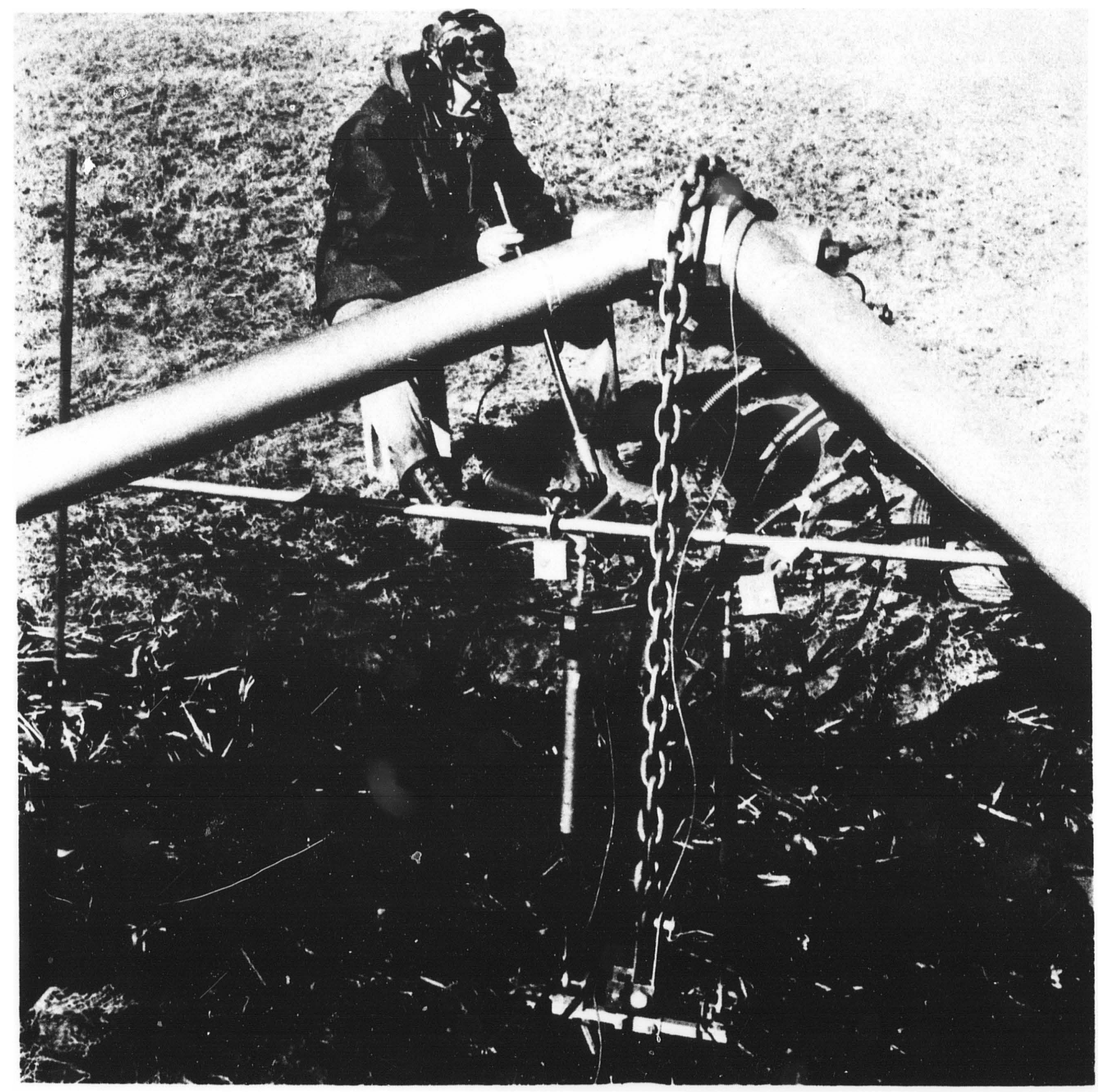

6. RECOMMENDATIONS

\section{6,1 REQUIRED LOAD CAPACITY}

\section{Recommendation:}

It is recommended that the requirement for a $47251 \mathrm{~b}$ load capacity for anchors be abandoned. Instead, it is recommended to stipulate the required total working load that the anchoring system must resist, and then determine the number of anchors required to achieve this performance on the basis of anchor capacity 
that can be achieved at particular sites. This requirement will have to be coupled with a maximum allowable spacing requirement to avold unreasonably wide spacing in dense solls. The implementation of this approach will require an initial estimate of the anchor capactiy at an installation site either by a load test or by previous experience. To avoid unnecessary costs the allowable working load for the anchors could be established during the pre-loading of the first anchor installed on the site.

Commentary:

As a result of this test program, it was determined that on the sites selected, which had competent solls, existing anchor technology did not provide the required 4725 lb load capacity required by ANSI Al19.3.

\subsection{INSTALLATION REQUIREMENTS}

Recommendations:

The following procedure is recommended:

1. Each anchor instialled must be preloaded to 1.25 its working load.

2. One anchor per mobile home, or three anchors per site where the soil conditions are uniform, must be preloaded to 1.5 the working load.

3. The working load $\left(P_{w}\right)$ is defined as the anchor load induced by the design wind pressure (without the 50 percent increase required by HUD) [9].

A suggested preloading procedure for diagonally loaded anchors is shown schematically in figure 6.2. Loading devices for vertically loaded anchors are commercially available.

Commentary:

Figure 6.1 illustrates the intent of the recommended procedure. The dashed curve is the loading curve of specimen $\mathrm{C7}$. The load capacity $O_{\mathrm{u}}=3.8 \mathrm{k}$, preload $P_{P}=3.17 k$ and working load $P_{w}=2.53 k$. If the specimen is preloaded in accordance with the recommended procedure, the reloading modulus will be high and the anchor performance, accordingly, excellent. Had the specimen been preloaded to $Q_{u}$, it is conceivable that the load capacity upon reloading would be less than $Q_{u}$. The 1.5 safety margin is intended to provide sufficiently high probability that the anchor will resist the working load. The $1.25 \mathrm{P}_{\mathrm{w}}$ preload will insure good anchor performance. Note that the reloading modulus would be much lower if the preload were only $1 \mathrm{P}_{\mathrm{W}}$.

The provision that some of the anchors should be loaded to $1.5 \mathrm{P}_{\mathrm{w}}$ is to provide some assurance that the preload will not approach the anchor-load capacity since this could weaken the anchors. Another way in which this could be accomplished 


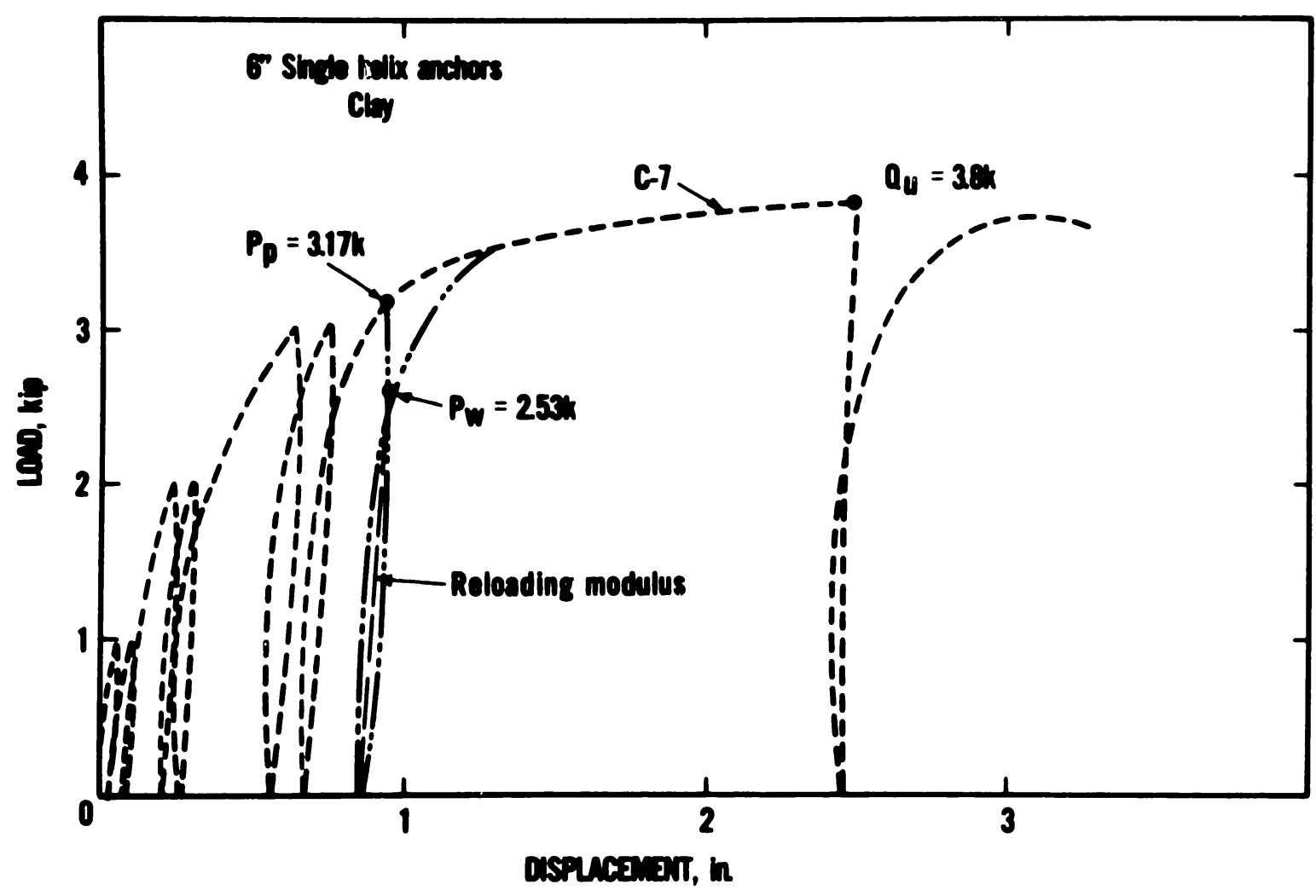

Figure 6.1 Illustration of the recommended preloading requirement and the resulting anchor performance 


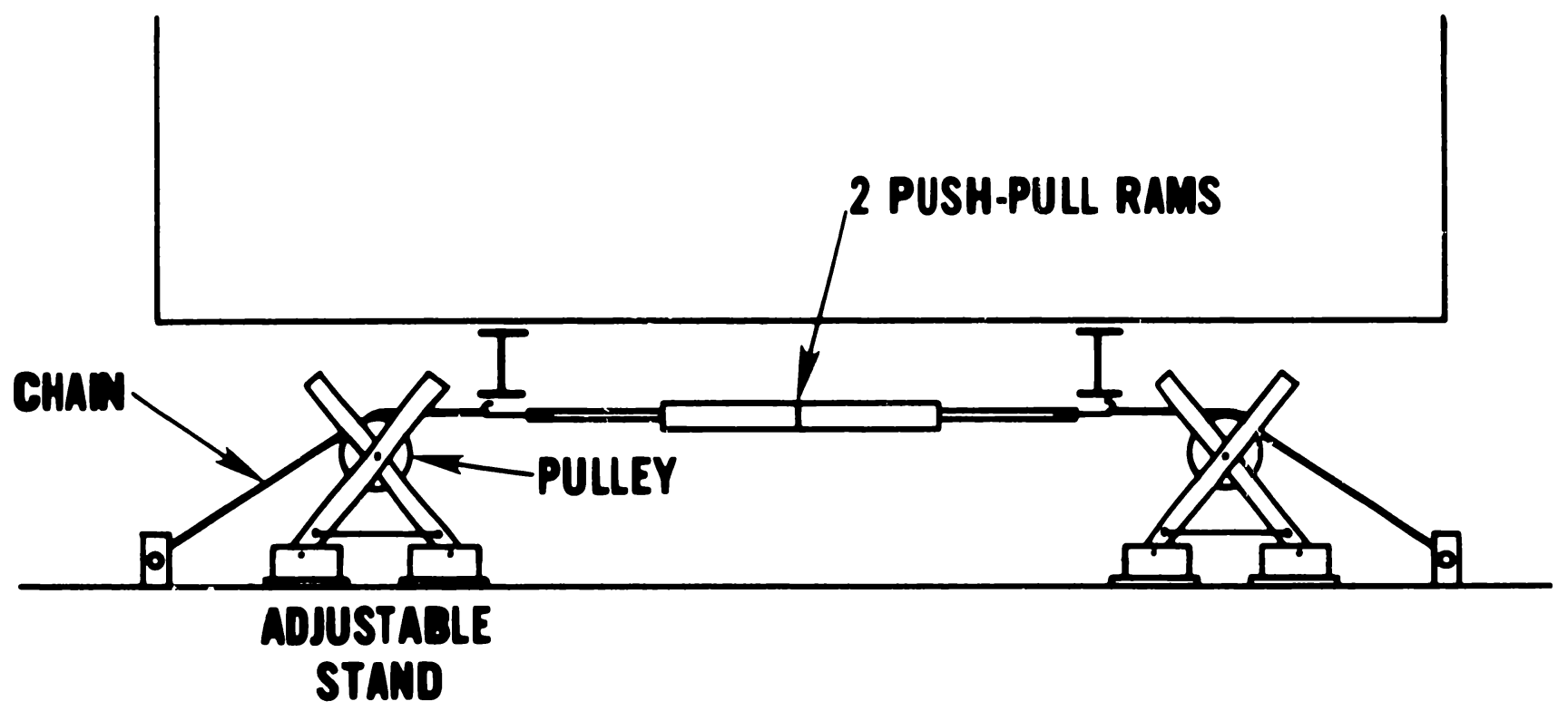

Figure 6.2 Suggested preloading procedures for diagonally loaded anchors 
would be to stipulate that the preload be held for five minutes without measurable creep (say not more than $1 / 4 \mathrm{inch}$ ). However such a procedure is considered too cumbersome.

It is conceivable on sites where the variability of anchor capacity is high that in some instances $P_{p}$ will be as high as $Q_{u}$. A good installer would probably decide in such a case that he needs more anchors and would reduce his preload. However, if he keeps pulling in order to try to reach the preload, he may pull out his anchors too much during the preloading process. This could be forestalled by stipulating a maximum allowable displacement during the preload1ng. However, it is difficult to come up with a displacement magnitude which could apply to all anchor types and soll conditions. A stipulation that preloading should be discontinued if an anchor moves more than two inches without an increase in applied load would probably provide adequate protection against overloading.

The test results also indicate that anchors preloaded by the recommended procedure would perform adequately under wind-induced cyclic loading.

\subsection{CORROSION PROTECTION}

Recommendation

Anchors should have adequate corrosion protection for the service life of the mobile home. The corrosion protection should remain effective after the anchor is subjected to inelastic deformations similar to those anticipated during preloading. Painting or any other coating that could be damaged by installation and preloading is not acceptable.

Commentary:

Most anchors tested lost much of their coat of paint during installation. Galvanized anchors would probably perform adequately, but there is concern that the anchor may become vulnerable to corrosion because of deformations induced by preloading or service load. All diagonally loaded anchors experienced large deformations in the shait, and most anchors tested experienced deformations in the hel1x.

\subsection{ANCHOR HARDWARE CAPACITY}

\section{Recommendations:}

Anchor hardware should resist two times the service load without rupture. Inelastic deformations are permitted if it can be demonstrated that the durability of the anchor will not be impaired. 


\section{Commentary:}

It is unrealistic to expect that anchor hardware should not experience Inelastic deformations as che anchor adjusts to the applied load. The safety margin of two is to insure that welds will not fall during anticlpated cyclic loads. 


\section{REFERENCES}

[ 1] Adams, J. I. and Radhakrishna, H. S., Uplift of Auger Footings in Fissured Clay, Ontar10 Hydro Research Quarterly, Vol. 22, No. 1, 1970, Pp. 10-16.

[2] ANS I Standard 119.3 (NEPA No. 501), Standards for the Installation of Mobile Homes, National Fire Protection Association, Boston, MA, 1975.

[ 3] Andread1s, A. et al., "Embedded Anchor Response to Uplift Loading, J. of Geotechnical Engineering Division of ASCE, Vol. 107, No. GT1, Jan. 1981.

[ 4] ASTM Designation D 1586-67 (Reapproved 1974), Standard Method for Penetraion Test and Split-Barrell Sampling of Soll, American Society for Testing and Material, Philadelphia, PA, 1967.

[ 5] ASTM Designation D 2487-69, (Reapproved 1975), Standard Method for Clazsification of Solls for Englneering Purposes, AS'TM Standards, Part 19, American Society of Testing Materials, Philadelphia, PA, 1975.

[ 6] Balla, A., The Resistance to Breaking Out of Mushroom Foundations for Plyons, Proceedings, 5th International Conference of Soll Mechaniss and Foundation Engineering, Vol. 1, Pp. 567-577, Paris, France, 1961.

[ 7] A. B. Chance Co., Encyclopedia of Anchoring, Bulletin 424, Centralia, MO, 1969.

[ 8] Davie, R. J. and Sutherland, H. B., Uplift Resistance of Cohesive So1ls, J. Geotechnical Engineering Division, ASCE, Vol. 103, No. GT9, Paper 113223, Sept. 1977 .

[9] Department of Housing and Urban Development, Mobile Home Construction and Safety Standard, Federal Register, Vol. 70, No. 244, Title 24, Chapter II, Part 280, Subpart D, November 1979.

[10] Harvey R. C. and Burley, E., Behavior of Shallow Inclined Anchorage in Cohesionless Sand, Ground Enginerring, Vol. 6, No. 5, 1973, pp. 48-55.

(11] Kananyan, A. S., Experimental Investigation of the Stability of Bases of Ar.chor Foundations, Soll Mechanlcs and Foundation Engineering, No. 6, 1966, Moscow, U.S.S.R., June 1966.

[12] Kovacs, W. D. and Yokel, F. Y., Soll and Rock Anchors for Mobile Homes, A State-of-the-Art Report, NBS Bullding Science Series 107, National Bureau of Standards, Washington, D.C., October 1979.

[13] Marshall, R. D., The Measurement of Wind Loads on a Full-Scale Mobile Home, NBS IR 77-1289, National Bureau of Standards, Washington, D.C. September 1977 . 
[14] Meyerhof, G. G., Uplift Resistance of Inclined Anchors and Piles, Proceedings, VIII International Conference of Soll Mechanics and Foundation Engineering, Vol. 21, pp. 167-172, Moscow, U.S.S.R., August 1973.

[15] Schmertmann, J. H. and Palacios, A., Energy Dynamics of SPT, Journal, Geotechnical Engineering Division, ASCE Vol. 105, No. GT8, August 1979.

[16] Seed, H. B. and Chan, C. K., Clay Strength Under tarthquake Loading Condition, Journal, Geotechnical Engineering Division, ASCE, Vol. 92, No. SM2, March 1966 .

[17] Texas Department of Labor and Standards, Mobile Home Division, Standards and Requirements 0.63.55.07, Texas Register, Vol 3., No. 78, Austin, TX, October 1978.

[18] Tsangarides, S. N., The Behavior of Ground Anchors in Sand, Doctoral Thesis, University of Londong, Queen Mary College, January 1978.

[19] Yoke1, F. Y., Chung, R. M., Yancey, C. W., NBS Studies of Mobile Home Foundations, NBSIR 81-2238, National Bureau of Standards, Washington, D.C., March i 981 .

[20] Yokel, F. Y, Yancey, C. W., Mullen, C. L., A Study of Reaction Forces on Mobile Home Foundations Caused by Wind and Flood Loads, NBS Building Sclence Series 132, National Bureau of Standards, Washington, D.C., March 1981. 


\section{ACKNOWLEDGMENTS}

The contribution of the following persons is gratefully acknowledged:

Mr. James McCollom of HUD monitored the NBS contract and made many constructive suggestions; Dr. William D. Kovacs of NBS conducted the state-of-the-art study which recommended this work and contributed to the planning and interpretation of the tests; Mr. Christopher L. Mullen participated in the design of the test rig; Mr. J. T. Odom of A. B. Chance Co. reviewed the design of the test rig; $\mathrm{Mr}$. Erik D. Anderson and Mr. Mike P. Glover participated in the testing work in the field; MHA corporation, Minuteman Corporation, A. B. Chance, Tiedown Engineering and Abema, Inc., supplied anchor hardware and installation devices, gave advice, and installed some of the anchors. Some of this assistance was rendered at no cost to the government. Schnabel Engineering Corporation identified two of the test sites and conducted the soll exploration on all the test sites. 

APPENDIX A

Test Sites

\section{A.1. Introduction}

Appendix A Contains information on anchor location and subsurface information on three test sites. Site $A$ is in silty soil; Site $B$ is in sandy soil; and Site $C$ is in clay soil.

Figures Al through A4 show the location of anchor tests, test borings and test pi¿s. The anchor-location coordinates are given for each test identified in Appendix B. Tests W1 through W17 on Site A are located in a drainage swail where the soil is permanently submerged.

There are two separate test areas on Site B. Area B2 was chosen because part of Area BI was overlain by a dense crust and thus some of the test locations were not utilized. A test p1t was dug on Site B2 to explore soil conditions.

The appended soil exploration reports contain the logs of the borings shown in the location maps, as well as laboratory test results. Information on Soll Test Probe readings is included in the tables in Appendix $B$. 


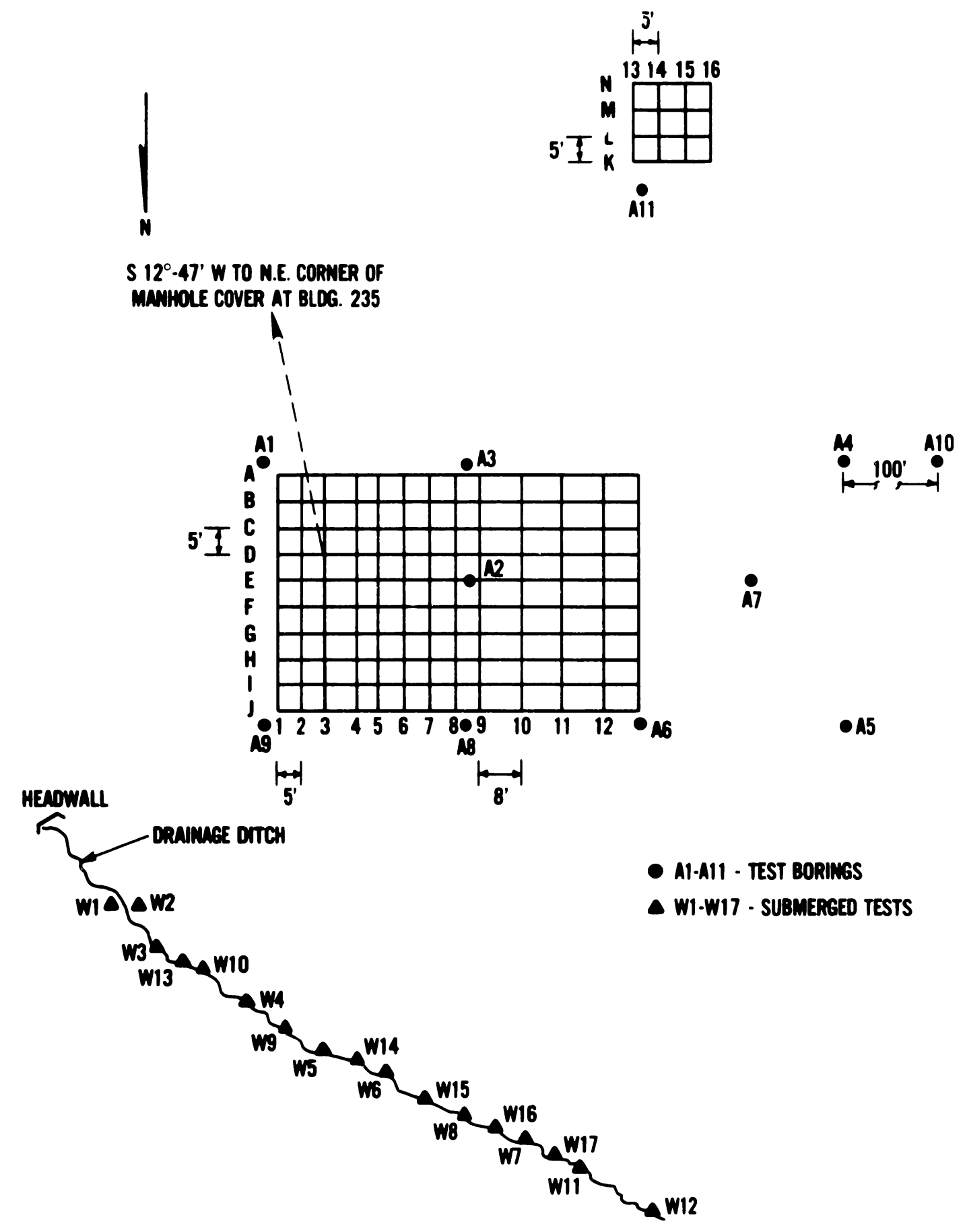

Figure A.1 Anchor Test and Boring Locations on Site A 


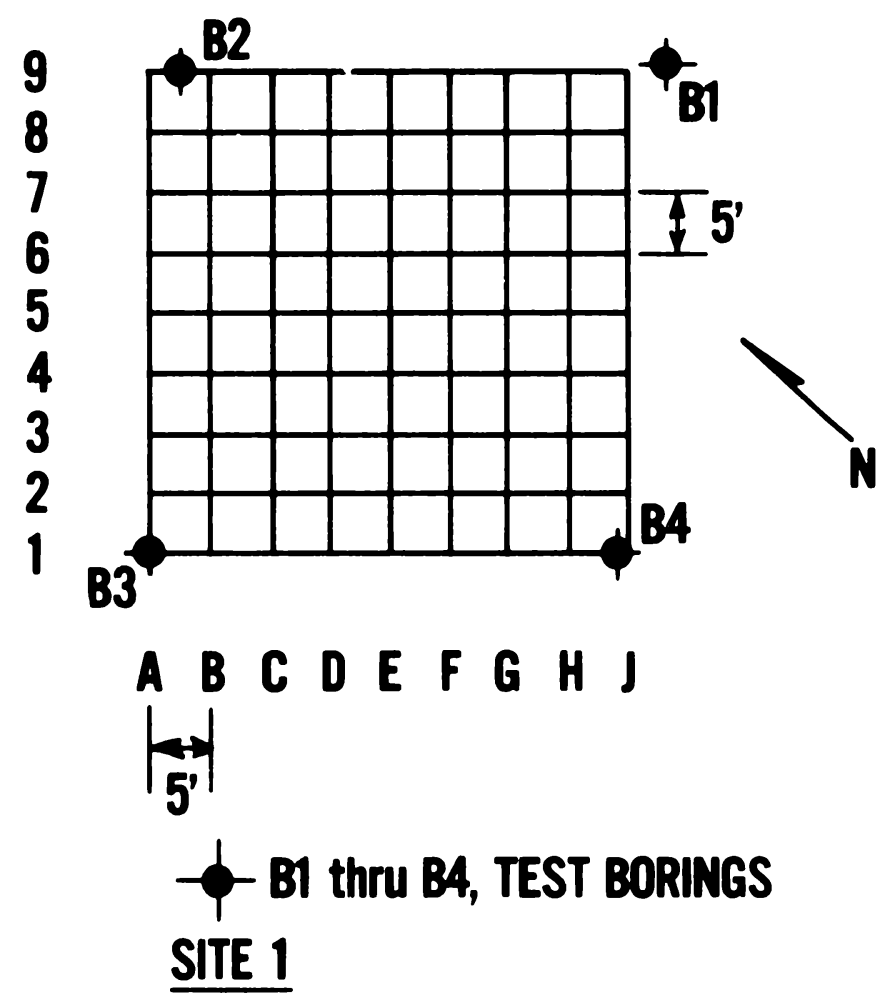

Figure A.2 Anchor Test and Boring Locations on Site B.1 

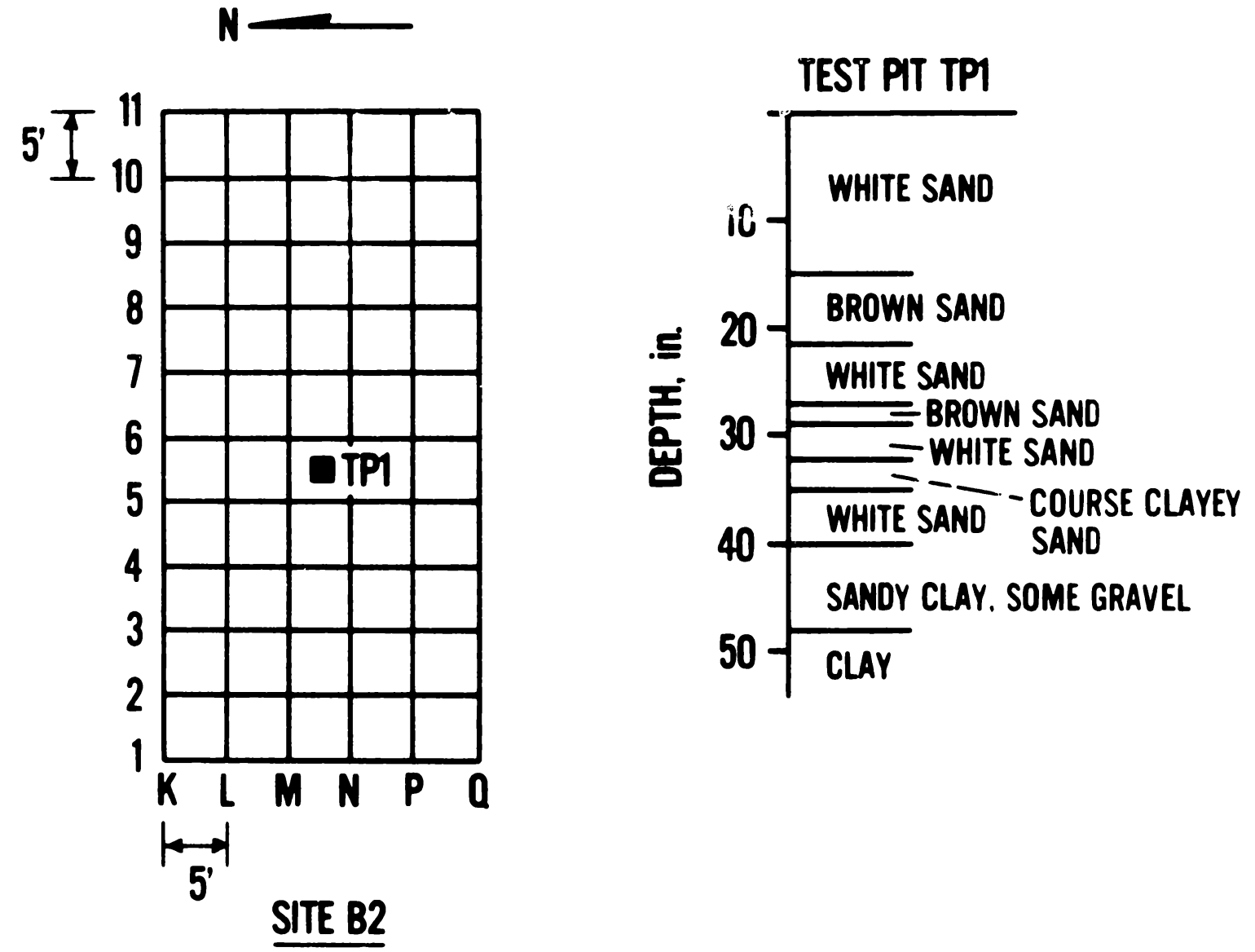

Figure A.3 Anchor Test and Test PIt Locations on Site B.2 


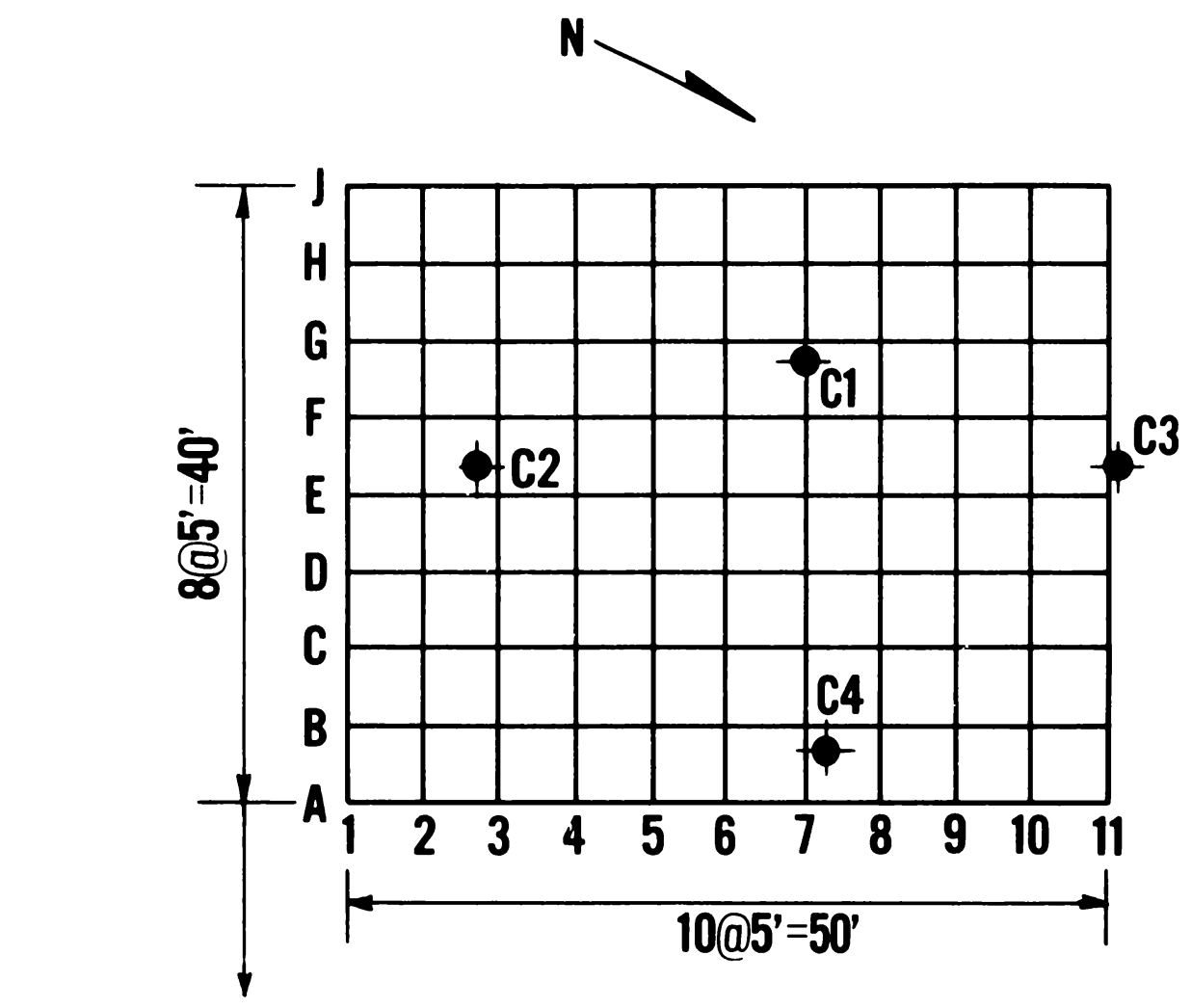

45' to edge of pavement

- C1 thru C4, TEST BORINGS

Figure A.4 Anchor Test and Boring Locations on Site C. 
A.2 Soil Exploration Reports 
SCHNABEL ENGIVE ERINC .ASS̈OCIATES

$$
\text { CONSLLTINC ENCINFERS }
$$

SOIL MECHAWIS AID FOI UIATINS

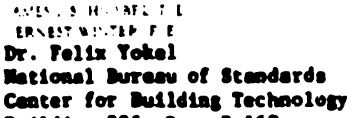

thetional vurean of stcosdarde

Ceacer for milldias Techoolong

nowemes S. 1979

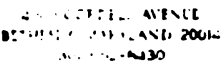

uideding 226 , 2000 2-16,

Projece:

\section{Teet ing Sorvices for Mobile vom \\ tochorage Projact. Thase 1, Various}

Locetione. Washington, D.C. area

\section{Eoport for site "A"}

Mational Dureau of stendarde.

Gootienen:

占 Subntted herenth are four coples of our report of eubeoll exploratson and ooll laboratory teating for the flrat alte on thle project, deeignated 81te "A".

sise

The test elte for this series of ceate we on the Mational burcau of

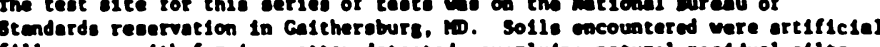
111. rock of the Miocenickon Pornet 100 .

\section{Peld Teating}

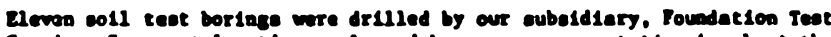
harvice, Inc.. at locationo celected by your reprecentetive in about the

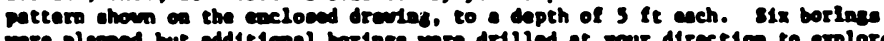

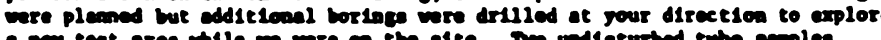

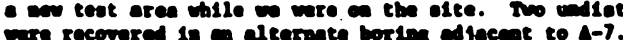

Dr. Pel1x Yoke1
Novewber 5, 1979

Pore no

Group eyabole after the deneription of colle are in eccordance with the in Encluevire (1), Identification of Soll.

The etandard penetration resiotence, or $\mathrm{M}$ value, Indicate the penetration

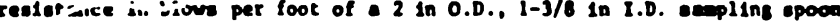
dr:ven with - 140 to hamer falleng 30 in per ASTM D-1586. After an InItelel cet of 6 in to cesure the empler 1s in undisturbed aeterlal, the number of blowe requited to drtve the eapplet an addtional 12 in lo vouslly taked a. the $N$ value. The penetrotion lor ach

no groundwater vas observed in any of the borings during drilling or up
to 3 hours after drilling. Long tern water observations were not mee. Soll Laboratory Tentins

Matural woleture content teats vere conducted on jar emaples and a antural deneity test was performed on one tube eapple. Atterbert Lints and oleve

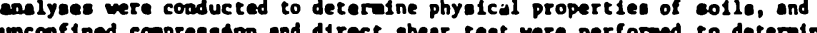

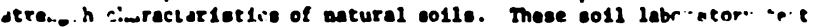
reoulte are anarised in Enclosure 2, and Indicate that the natural sodie teated are typically a clayey allt, with come fine and, or Ra according to

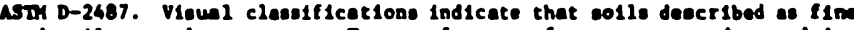
andy ellt are 01 co present. Traces of quartz frogente wre detected is dry denelty of oleture contente ranged troa 12.5x to $30.0 x$. The notural dry deneity of one epeciend was 97.6 pef. 4 Strensth testing Indicated as

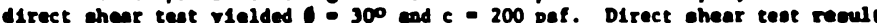

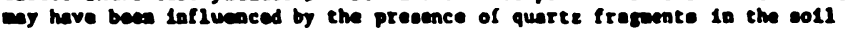
opeciones.

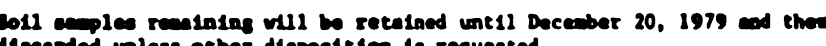

pleace call if there are questions concorning this Inftial oubatteal.

very truly yours.

mel:

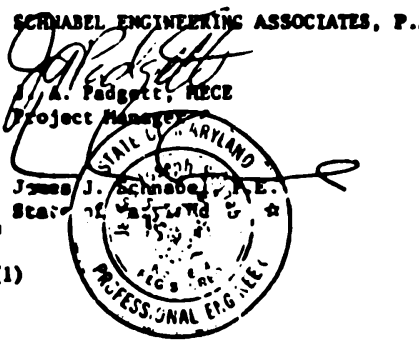




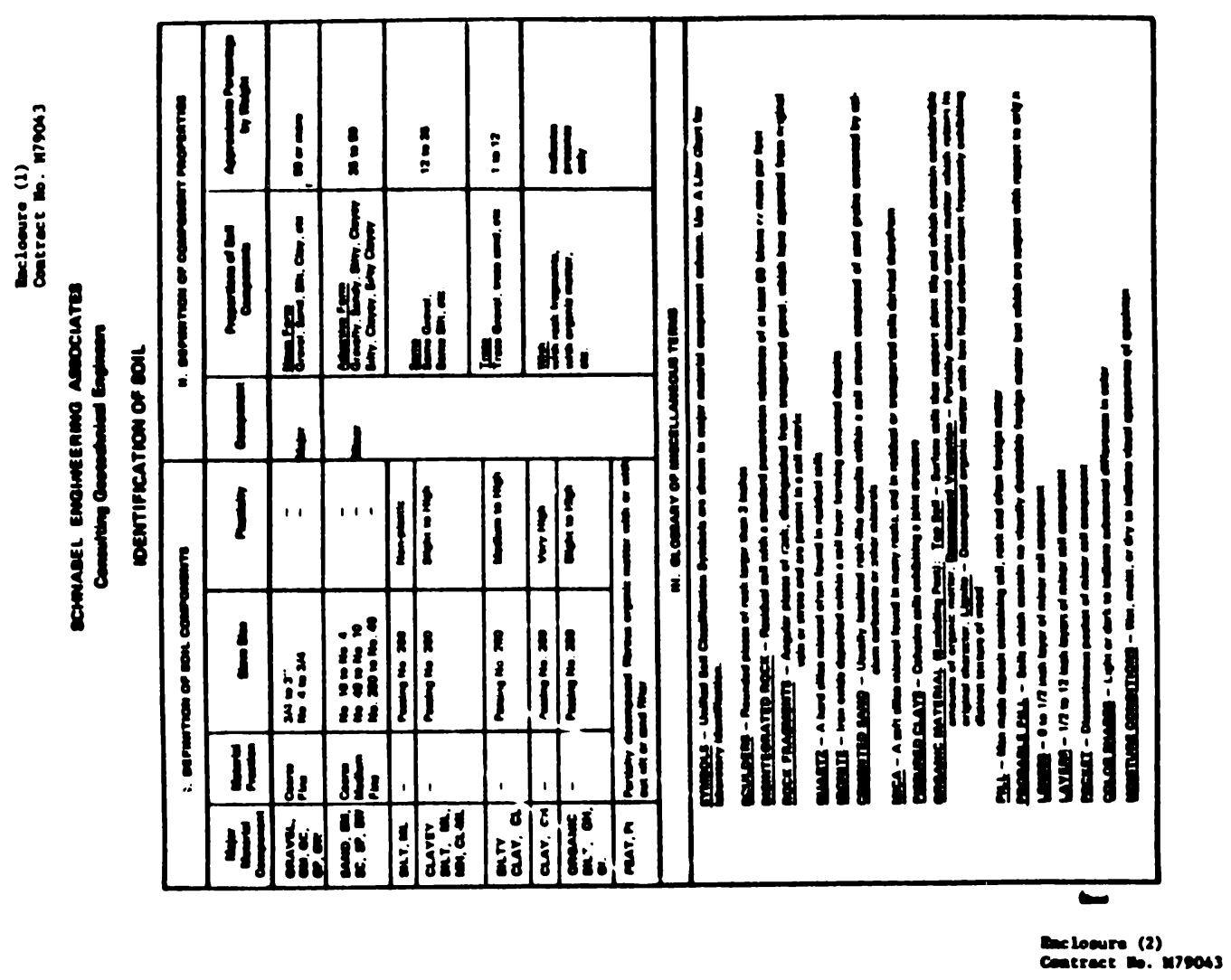

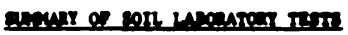

\begin{tabular}{|c|c|c|c|c|c|c|c|c|c|c|c|}
\hline Ooring & $\operatorname{lom}_{\log } 10$ & $\sum_{\pi / 0}^{10}$ & $\begin{array}{l}\text { Deceripeion } \\
\text { of soll } \\
\text { species }\end{array}$ & $\begin{array}{l}\text { Percent } \\
\text { Pesolng } \\
\text { 10. } 200 \\
\text { IIewe }\end{array}$ & $\begin{array}{l}\text { Actert } \\
\text { unts } \\
\text { Lin }\end{array}$ & pis & $\mid \begin{array}{c}\text { Dotural } \\
\text { Moloture } \\
\text { (z) }\end{array}$ & Sote & $\begin{array}{l}\text { urel } \\
\text { elty } \\
\text { ef) } \\
\ln \end{array}$ & Port1 & enerte \\
\hline$\Delta-5$ & $1.5^{\circ}$ & $\operatorname{sax}$ & Curd snt, & - & 3927 & 12 & 17.6 & - & - & - & Eseces of encese \\
\hline$\Delta-10$ & $0 . S^{\prime}-2.5$ & مמin & 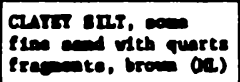 & 62.0 & - & - & 19.0 & - & - & - & Seo crentien Curve \\
\hline$\Delta-70$ & is & $3^{\prime \prime}$ & 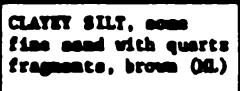 & 03.0 & - & - & 21.6 & 130.1 & 270 & 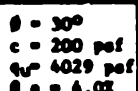 & 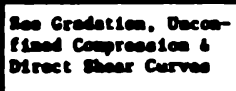 \\
\hline
\end{tabular}

Dotees

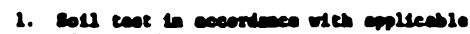

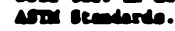

2. Coll elacolflestion orolo aro in

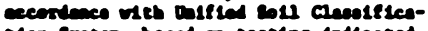

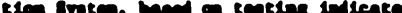
an denl istertication.

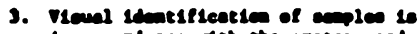

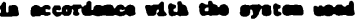
b) ento ers.

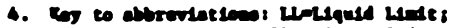

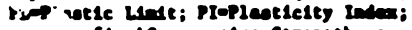

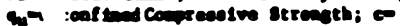

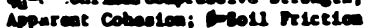
celo; cuernin. s. Hetral olature ceatent

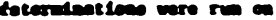
jer $\rightarrow$ le tre all borin.

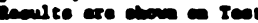
corter mere.

6. Coll teoce wro condueted b 2. Trullo, R. Eet111, 

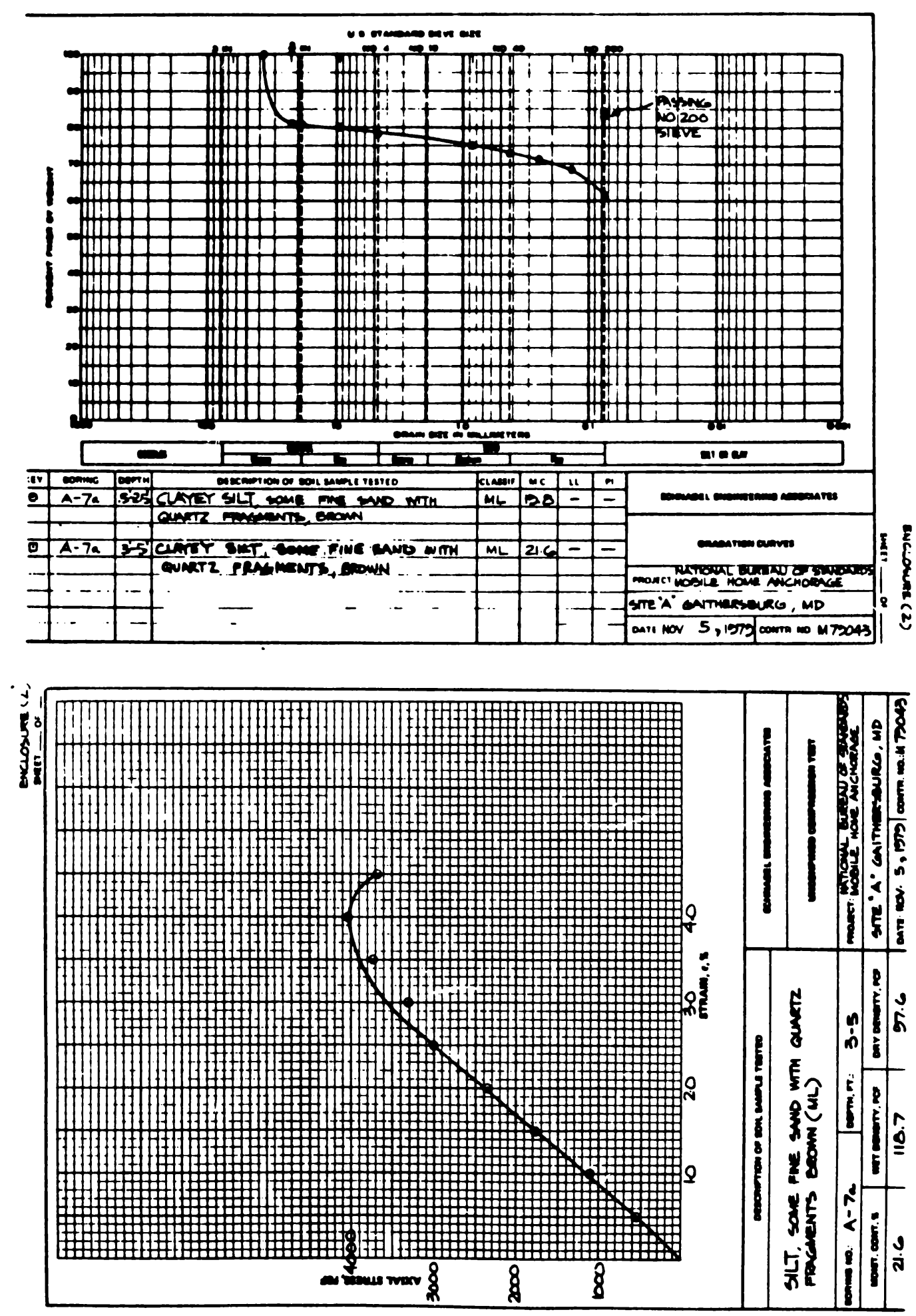


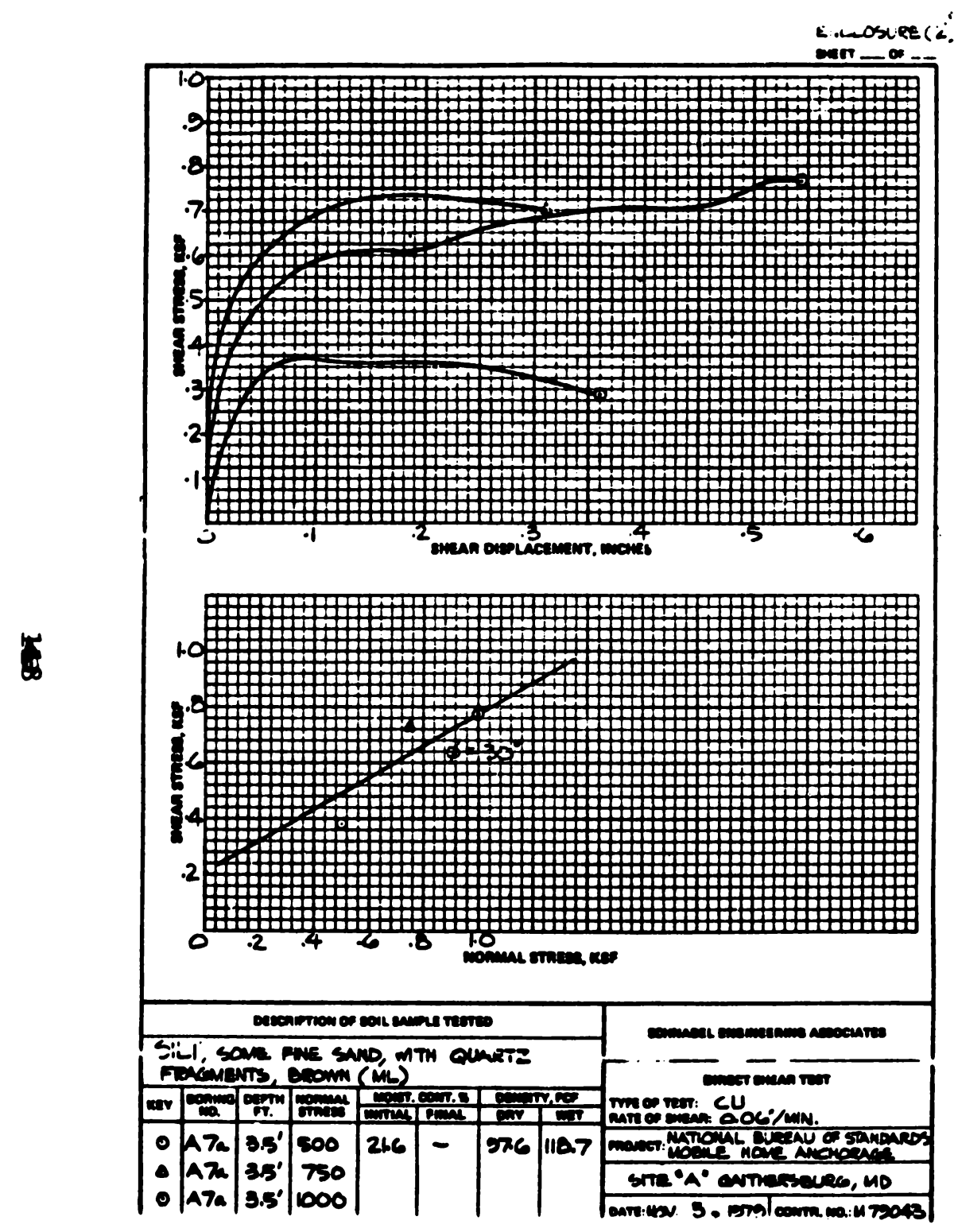

Encluoure ( 3 )

rontract Mo. Y79063

SUGSOIL LAUESTIGAT LON REPORT

Test Boring Report

Description of Subsoll Investigation Procedures:

1. Test Borlare

Hollou Stee Aurers

The borinas are advanced by tu:ning an auger with a center opening

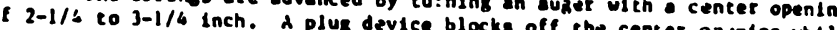
sakers are advanced. Cuttinge are brojght to the surface by the euger flighte. by standerd pethode. After removal of the plugg in the hellow atum auger, Into the boring uat af chis procoval of the plug. No water uns introduced

2. Scendard Penectection Teats

Tescing is perfomed by driving 2 inch $0.0 ., 1-3 / 3$ inch 1.0 140 pound haon through three 6 inch intervals or as Indicated, velng 140 pound hataer falliag 30 inches, according to ASTY D-158h.

3. Eorine Locaclone and Grades

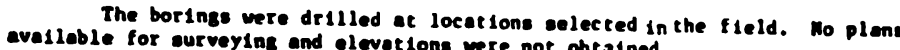


BORING MUMBER AI GROUNO SUAFACE ELEVATION

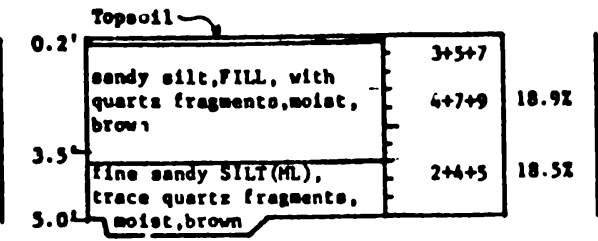

cotton of bortas $5.0^{\circ}$

BORING CORPLETED 7-19-79

MATER LEVES READINGS

ENCOUNTERED NORO

UPON COMPIETION Done

MATER nON.

AFTER $4.5 \mathrm{hrs}$

CAVED AT -
Dorimg muajaer az CROUNO SURFACE ELEVATION

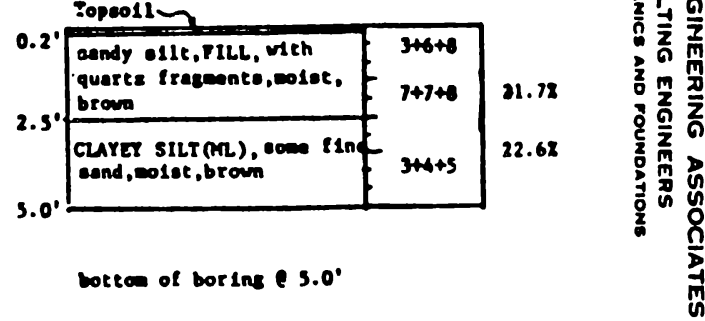

BORING CORPLETED $7=19-79$

MATER LEVEL READINGS

ENCOUNTERED nONE

UPON COMPLETION nOBE

MATER MONE

AFTER 3 hro

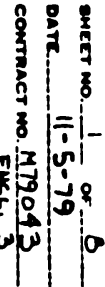

BORING MUMBER AJ

GROUNO SURT ACE ELEVATION

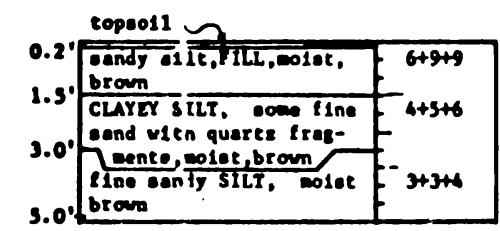

botten C: bor1as $5.0^{\circ}$

BORING COMPLETED 7-19-79

MATER LEVEL READINGS

ENCOUNTEREU DORO

UPON COMPLETION DOAO

WATER DONO

CAYED AT -
AFTER $2.5 \mathrm{hrO}$

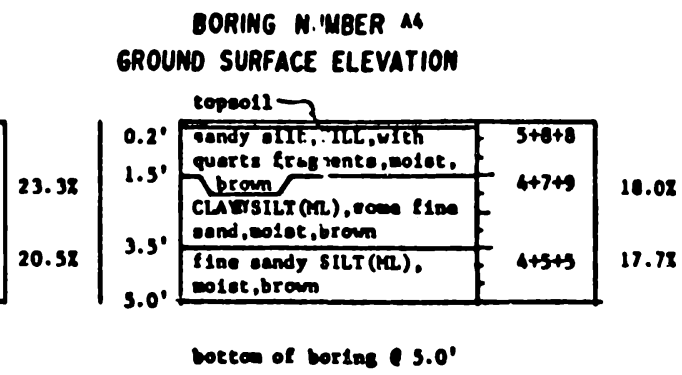

BORING COMPLETED 7-19-79

MATER LEVEL READIMGS

ENCOUNTERED

UPON COMPLETION none

MATER MONO

AFTER 24 hro

CAVEd AT -

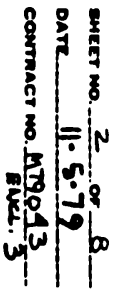


DOPJNG nUMBER AS EROUWD SUAFACE ELEVATION

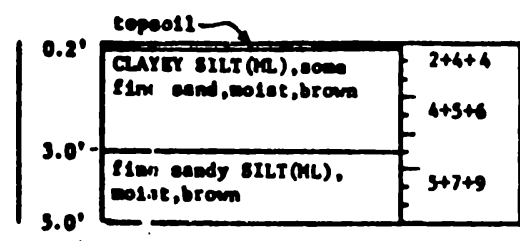

onitea of borime 5.0

BORING COFPLETED 7-19-79

MATER L $:$ VEL READIMGS

ENCOUNTTAED WOE

UPON COMPLETION none

WATER wose to 4.9',

CAVED AT 4.9'and dry
BORING nUMBER as CROUNO SUAFACE ELEVATION

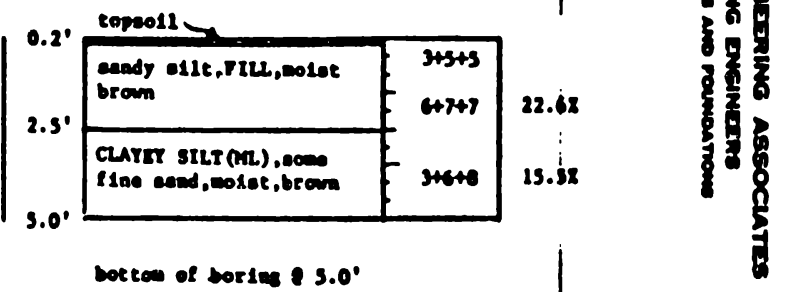

DORING COMPLETED 7-19-79

MATER LEVE READIMGS

ENCOUNTERE ? WOW

UPON COMPLFTION DORE

MATER MOD

CAVED AT -

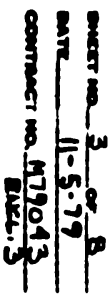

DOP:NG NUMBER AT ind A70 GROUNO Si'TFACE ELEVATION

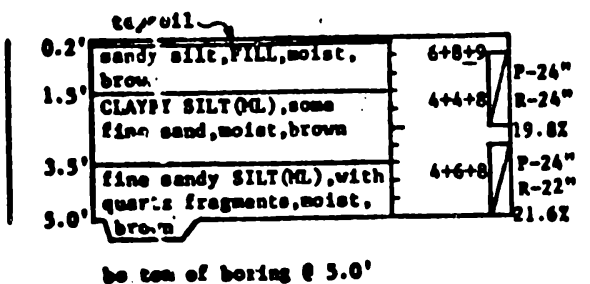

to con of worise $3.0^{\circ}$

DONIII COMPLETED 7-19-79

MATEP DEVEL, READIMGS

ENC.O. VTERED Dono

UPON COMPLETION Doso

MATER DoDO

AFTER 1.3 Wr

CAVEd AT -

Alearante boring Ala drillod to

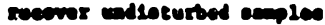

BORIMG MUMBER AO GROUND SURFACE ELEVATION

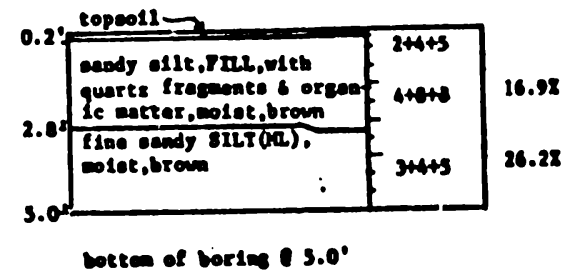

BORIIT COPPLETED 7-19-79

MATER LEVEL READIWGS

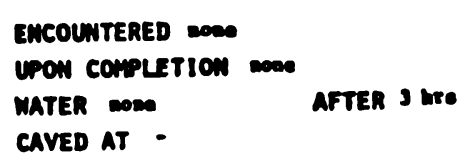

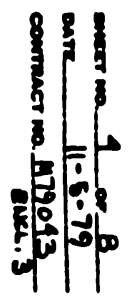


DCRIMG MUMOER AS enoum sUnface eleVATION

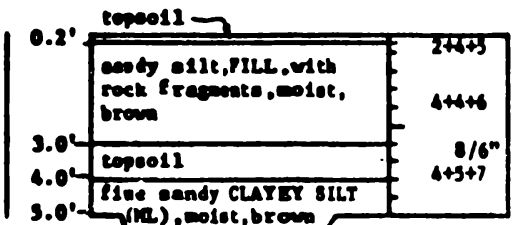

(19e).eoloc, brome

certen of witne $3.0^{\circ}$

conim COFPLETED 7-19-79

MAIER LEVEL READIMGS

ENCOUNTERED Dose

UPON CIMPLETION DON

WATER mono

caves ir -
DORIMG MUMBER alo GROUNO SURFACE ELEVATION

26.38

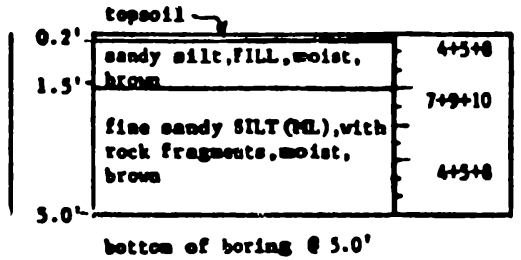

18.04
12.5
13.98

DORING COFPLETED 7-19-79

WATER LEVEL READINGS

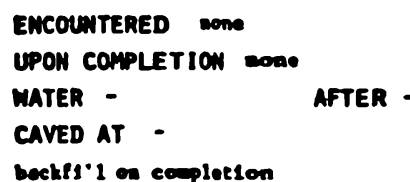

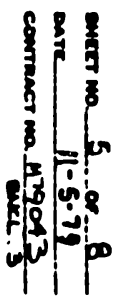

DORING MUMAER AH CBOUNO SUMFACE ELEVATION

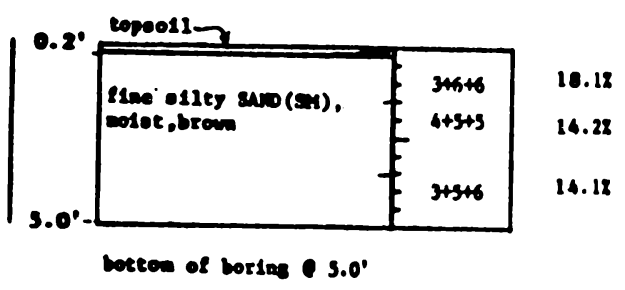

DORING COMPLETED ?-19-79

WATER LEVEL READINGS
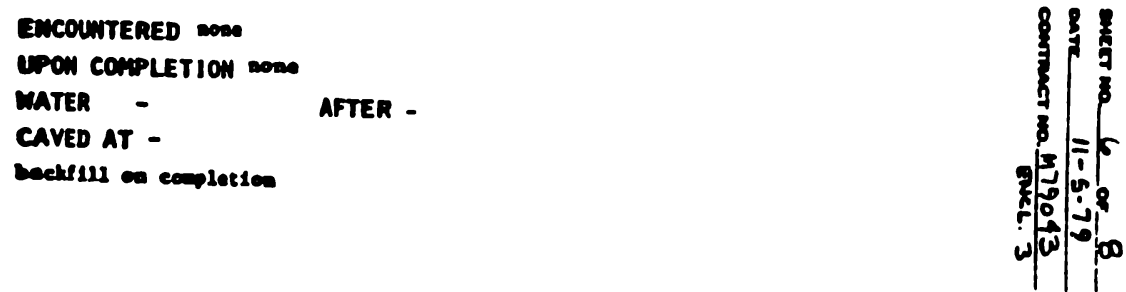


\section{sheot 7 of $B$}

179043 EMKL3

GENeAl mTES

1. Maber to right wad colus ledicate the anber of blowe requitred to

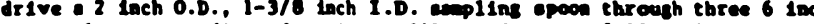
intervall or as 1adicated, wing a 160 pound homer falling 30 1eches. eccordin to ASm D-1586.

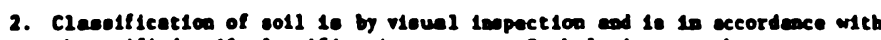

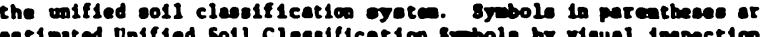

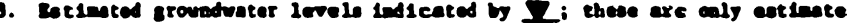

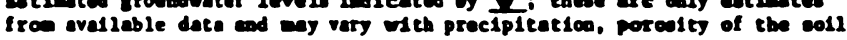
elte topostaphy. ete.

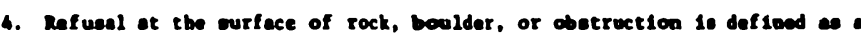

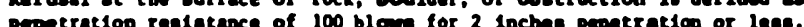

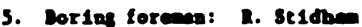

6. Roy to ebbreviatione end expole:

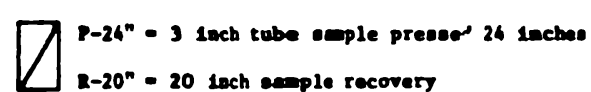

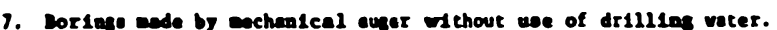

8. Doring layout wae provlded by others. Wo elevations were obtalned.

D. The borins loge and re! ated laformation depict aubeurf ace conditiono only at these opec1fic locat) one and at the particular tiee then drilled. So1 conditions at other li jetiona coy differ from conditione occurring at these borias locations. Noo, the pastase of the any result in change

10. The etrat1f1cat1oe 11bee rapresent the approztante bovadary betwer soll

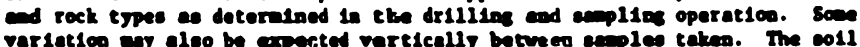

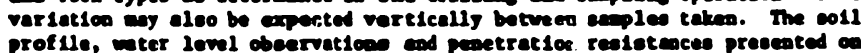

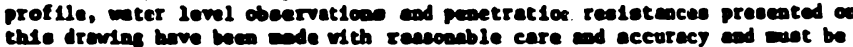

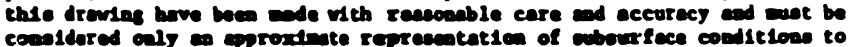

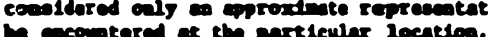

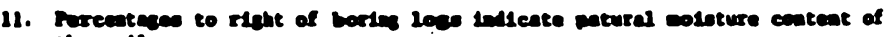

SCHNABE ENG IESRING ASSOCIATES CONEULTING ENGINEERS

anrer mo. $\frac{8}{11-5 \cdot 19}$ commact mo. $\frac{M 72043}{6 x^{2}}$

COT LOCATON SKETCH TEST SITE "A"

MOBILE HOME ANCMORACE PROEET

NATIONAL BUREAU OF

STANDARDS

GAITHERSBURG, 'MD

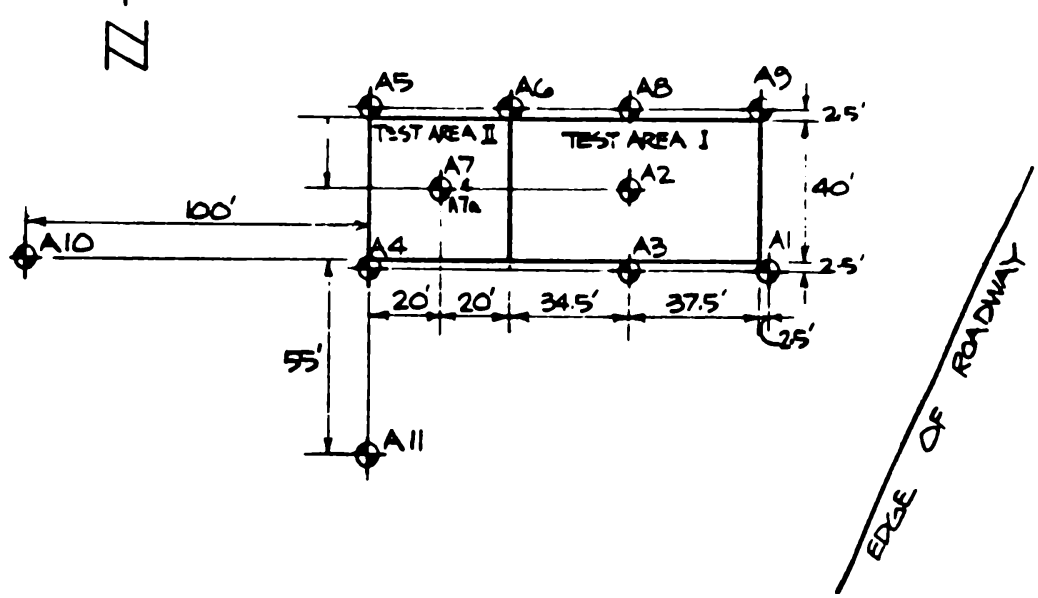


SCHINABEL ENC!NEERINC ASNOCIATES

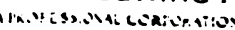

CONS:LIT... CESTECHNK. ENCINESRS

May 29, 1900

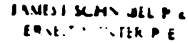

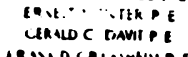

Mational Burcen of Scenderde

Center for Bulldins Technolon

culldias 226, Rooe 8-160

Weshington, D.C. 20236

Project:

Teating Servicee for nobile to Aechorage Project, Report for site "D" Odenton, Mryland

Attas Dr. Pellx z Yokel

Contlemen:

Subeitted herewith ore four coples of our report of enbeoll exploretion

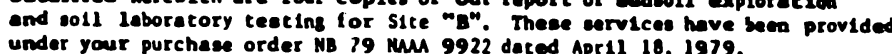

sices

The teat eite for this cories of teste wa in Odeoton, Marylad. Solle

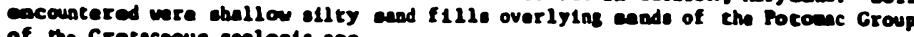
of the Crectecrous seologic ase.

\section{Ileld Teetion}

Pour coll teat borlage mie drilled by our absetdiers. Poundation Teat Service, Inc., to a depth of 10 feet cech. Worlage wre locatcd in a

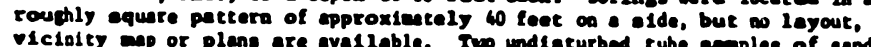
vicinity ap or plans are avallable. Two und laturbed tube complee of eavd were recovered in an al ternate boring edjacent to B-2. Tour la-ste ceatios within the bounds of the locerione drilled due to difficulty with penetrating enchors through very compect colle found at the eurfece.

Group eypbole af tar the description of eolle are in eccordence vitb

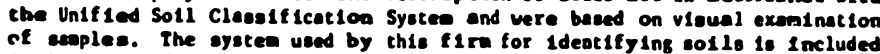
in Encloeure (1). Idencification of Sol1.

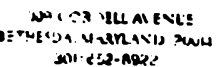

Nationel bureau of Stenderdo

Pese Two

The standard penetration resiotance, or N velue, indicates the

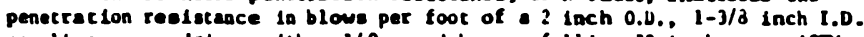
sapplins spoon driven with a 140 pouad hemer falling 30 inches per ASTM D-1586. After an initisl set of 6 inches to assure the suspler 1s in undiscurbed asterial, the number of blows required to drive the amplar ab additional 12 lincheo 10 unvally taken as the $N$ value. The peastration tor ach 6 inches of drive to strown in the right hand colum of the tesc boring

Mo groundwater was observed in any of the borings during drilling. Long term water observat tons were not ande.

Soll Laboracory Testing

Soll laburatory cost resulcs are oumorized in Enclosure (2). Natural oulsture content tests and natural density teats vere conductod on

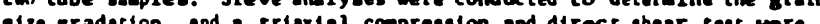
performed on remolded specitens to detenine strength charecteristices of solls.

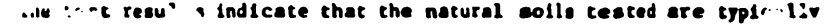

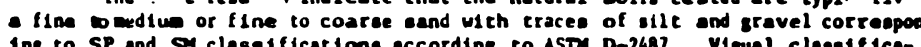
Ins to SP and SA cleselificatione according to ASTM D-2487. Viowal clossiticecrons indicate that aolls dencribed as, thae asty travelly and, and tine and are also present.

Matural molscure contente ranged from about 22 to 42 , utch setural dry denateles between bout 92 ead 118 pef. Sevorral notural density and fielded - $31^{\circ}$ and $29^{\circ}$ and $c-400$ paf and $c=0$, reapect ively. Ae requeated. - 50 per lack presente uas applied duriag eriaxial ceetias.

Soll eapplee reanining ulll be retalned uat1l July 11, 1960 and then diecerded

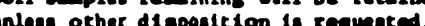




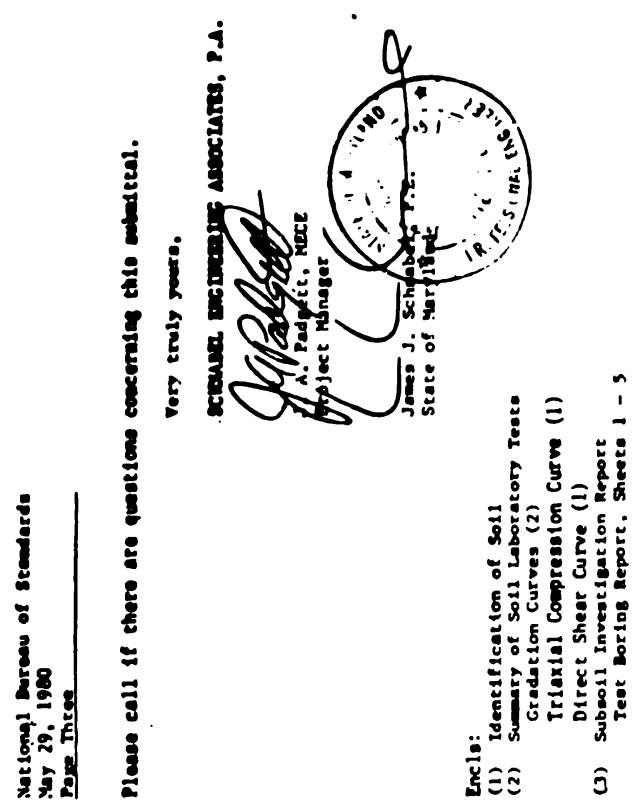

Enc losure (2)

Contract Mu. M79043

Dewar or goll LAEORATONY TESTS

\begin{tabular}{|c|c|c|c|c|c|c|c|c|c|c|c|c|}
\hline \multirow{3}{*}{ 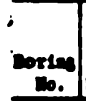 } & \multirow{3}{*}{ Depepte } & \multirow{3}{*}{ spepe } & \multirow{3}{*}{$\begin{array}{l}\text { Deceript 10a } \\
\text { of Soll } \\
\text { Execienn }\end{array}$} & \multirow{3}{*}{\begin{tabular}{|c|} 
Percemt \\
Peseing \\
Wo. 200 \\
sieve
\end{tabular}} & \multicolumn{3}{|c|}{ Mature! } & \multicolumn{3}{|c|}{ Reoolded } & \multirow{3}{*}{$\begin{array}{c}\text { Mewolded } \\
\text { Soll } \\
\text { Para- } \\
\text { metere }\end{array}$} & \multirow[b]{3}{*}{ Remerks } \\
\hline & & & & & \multirow{2}{*}{\begin{tabular}{|c|} 
Moleture \\
$(x)$
\end{tabular}} & \multicolumn{2}{|c|}{$\begin{array}{l}\text { Dene1 ty } \\
\text { (PCF) }\end{array}$} & \multirow{2}{*}{$\begin{array}{c}\text { Moleture } \\
\text { (2) }\end{array}$} & \multicolumn{2}{|c|}{$\begin{array}{c}\text { Deng1ty } \\
\text { (PCT) }\end{array}$} & & \\
\hline & & & & & & Wet & Dry & & Wet & & & \\
\hline $\mathbf{n}$ & $6^{\prime}$ & Jar & 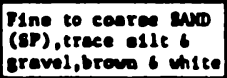 & 3.7 & & & & & & & & Soe: Gradation Curve \\
\hline \multirow[t]{2}{*}{$\mathbf{2 3}$} & $1^{\prime} 3^{\circ}$ & Tute & 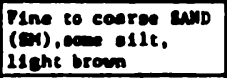 & 26.5 & $\frac{3.3}{6.0}$ & $\frac{108.1}{122.5}$ & $\frac{104.7}{117}: 8$ & & & & & See: Gradation Curve \\
\hline & do & $\infty$ & $\infty$ & do & & & & $\begin{array}{r}\frac{1.9}{3.1} \\
-\frac{5.4}{2.4}\end{array}$ & $\begin{array}{l}94.3 \\
96.7 \\
95.2\end{array}$ & $\begin{array}{l}92.5 \\
93.7 \\
93.0\end{array}$ & $\begin{array}{l}0.29^{\circ} \\
c=0\end{array}$ & $\begin{array}{l}\text { Sue: Direct Slicat } \\
\text { Curvee: } \\
\text { Mote } 6\end{array}$ \\
\hline $\boldsymbol{3}$ & $4^{1}$ & Jar & 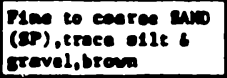 & 2.2 & & & & & & & & See: Grodation Curve \\
\hline
\end{tabular}

Eeriet

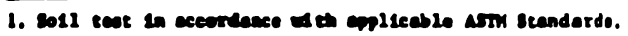

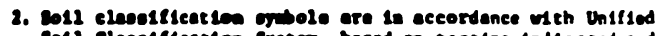
coll clangleseate syore viouel seatsflestion.

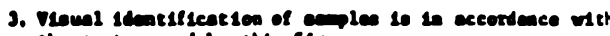

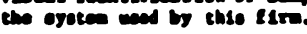

4. Rey to abbreviationa: do - dittg c - apparent cohosion

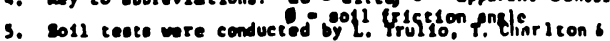
z. Lonnenbers.

6. Epecinene renolded to epproxiente wetural denelty and coloture lor etrength teating.

7. A so pal beck preseure uas applice to eriextol opue serens. 

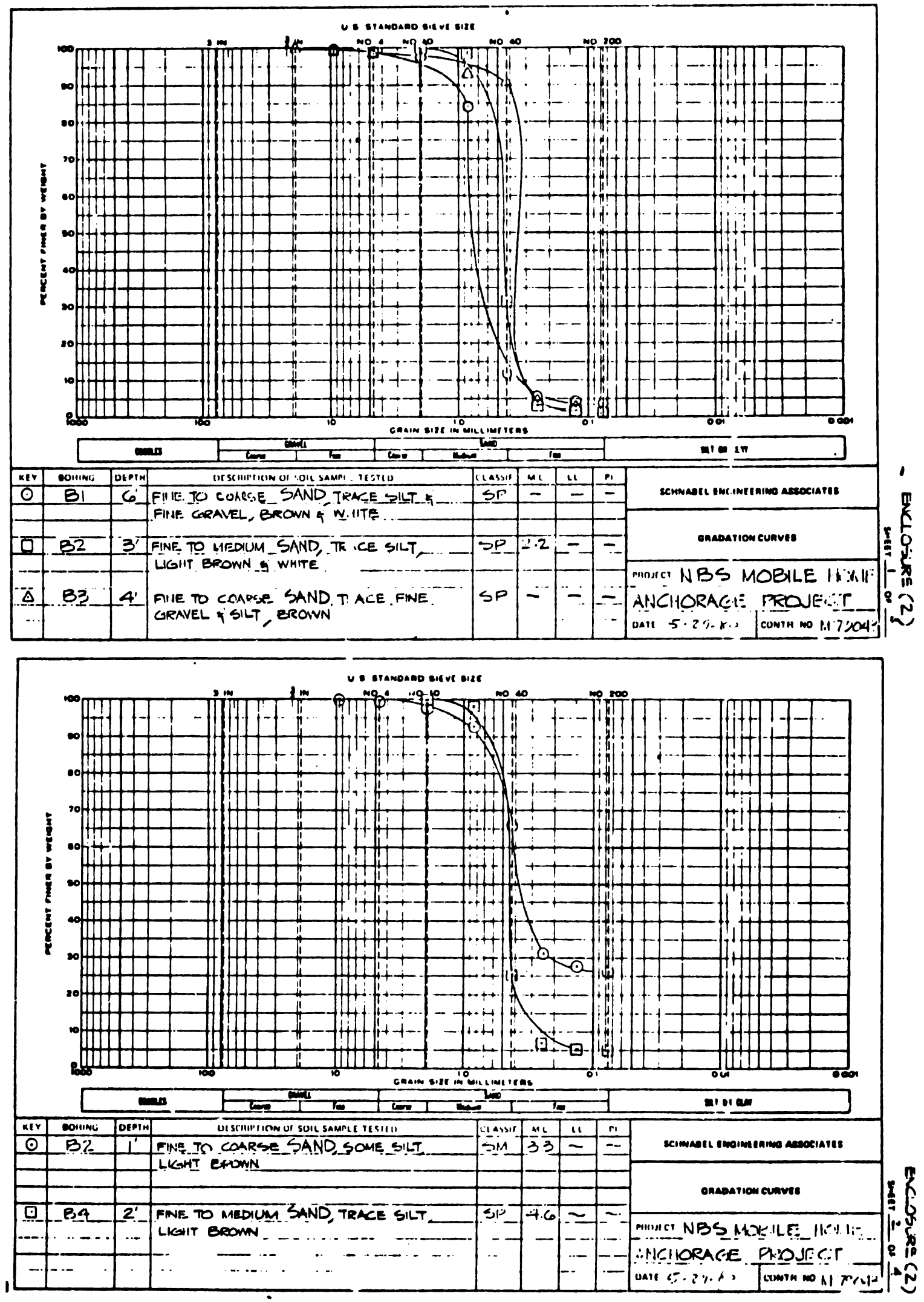

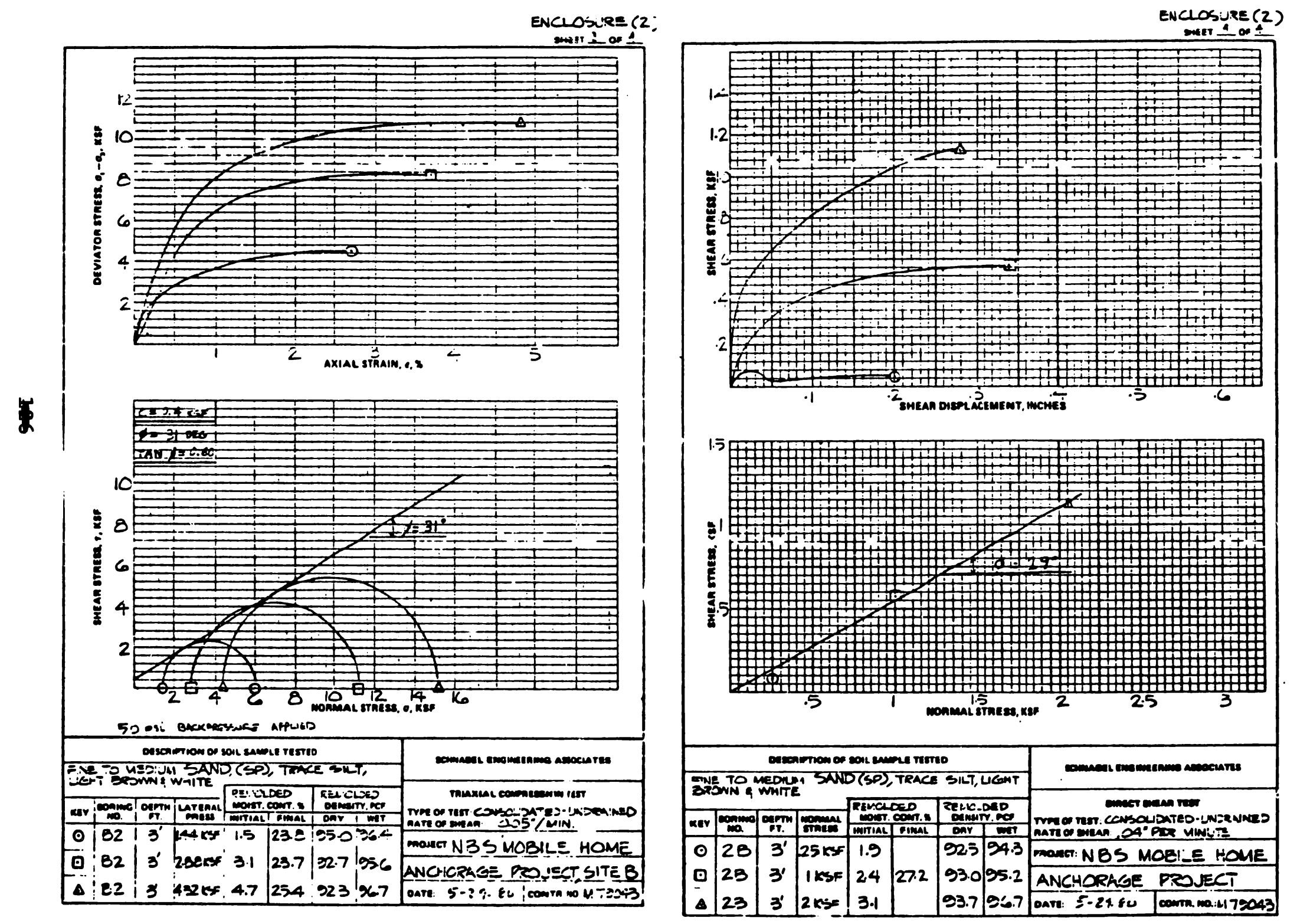
SCMNADX ENGINEERING ASSOCIATES CONBUR TIMO ENG MEERS com menames ano romonotions

contrect (3) mrsous ment no. $1.1 . .00 .5$

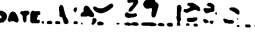
commact no. $4 ! .72 s=3$

E(․). (z);

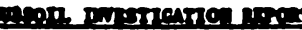

Teot bortus topert

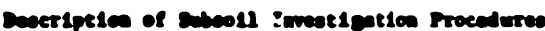

1. Ineserine

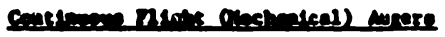

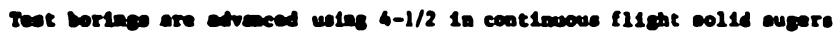

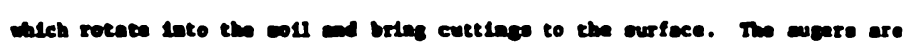

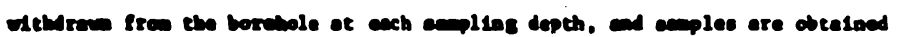

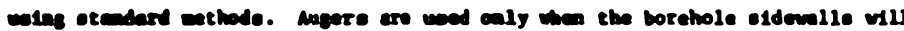

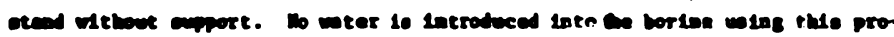
coture.

2. Stentel matretion teats

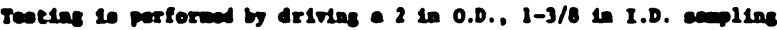

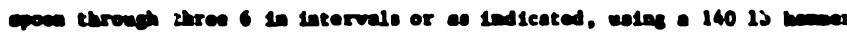

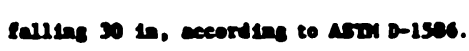

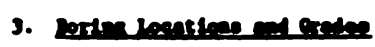

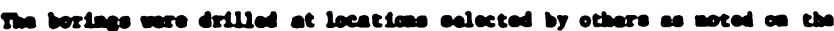

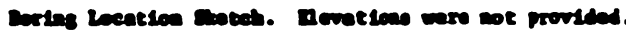

BORING NUMBER Bl GROUNO SURFACE ELEVATION -

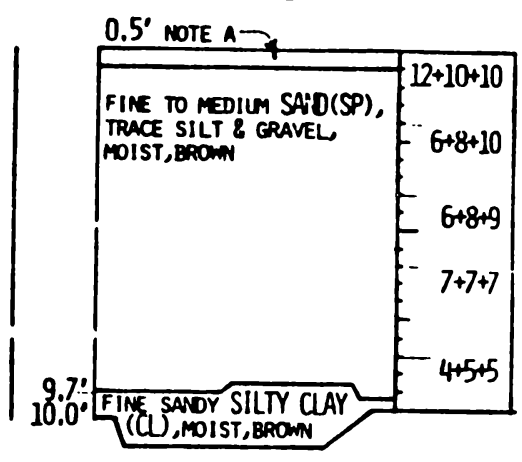

BOTTON OF BCRING a $10.0^{\circ}$

NOTE A:SILTY SND,FIL

WITH GAVEL MOIST,

BORING COMPLETED 10-30-80

WATER LEVEL READINGS

ENCOUNTERED RONE

UPON COMPLETION MONE TO $6.5^{\circ}$ (A)

WATER - AFTER -

CAVEd AT -

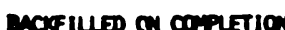


SCHNABE ENGINEERING ASSOCIATES

CONSULTING ENGINEERS

con meCMANICE AND ROUMOATION

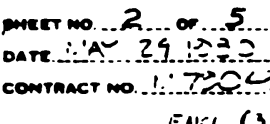

SCHNABE ENGINEERING ASSOCIATES

CONSULTING ENGINEERS

SOI MECMAMICS AMD FOIיNOATIONS encer mo 3 .... or ..5.

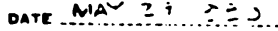
contract no $\$ 1,7 \geqslant$ Eactí(3)
DORING nUMBER B GROU:-) SURFACE ELEVATION -

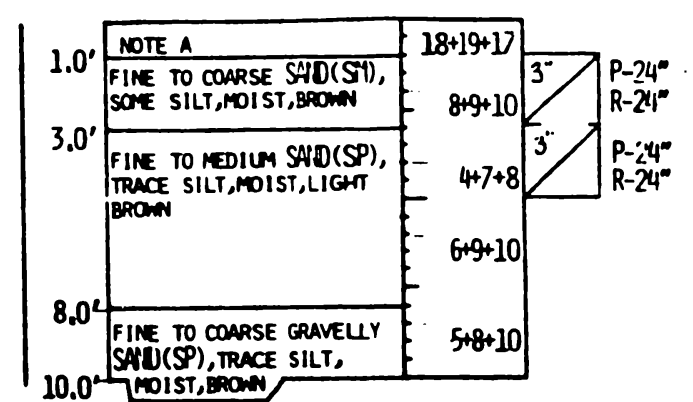

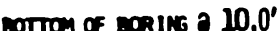

\section{WTE A:SILT sNo,FIL}

DORING COMPLETED 10-30-80

MATER LEVEL READIMGS

\section{ENCOUNTERED RONE}

UPOH COMPLETION TOE T. 6.

WATER AFTER -

CAVED AT

mariules on Corretion
BORING MUMEER B3 GROUNO SUAFACE ELEVATION -

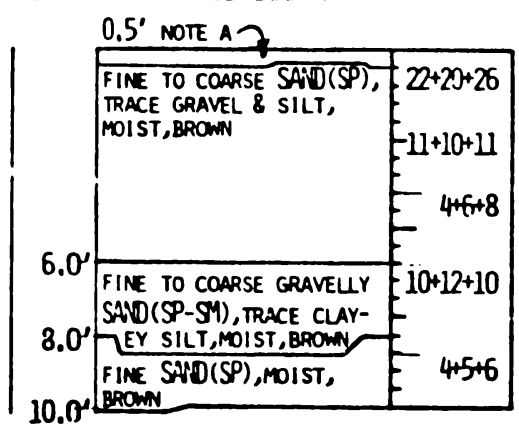

Botron of boring a $10,0^{\circ}$

NOTE A:SILT SAND,FIL

WITH GRAVEL,MOIST,

BROM

BORING COMPLETED 10-30-80

MATER LEVEL READIMGS

EnCOUNFERED MONE

UPON COMPLETION MONE TO 5.0 (A)

MATER -

AFTER -

CAVED AT -

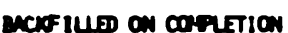


SCHNADI ENGINEERING ASSOCIATES

CONSULTING ENGINEERS

con meCmanice amo ROUmoations

DOMING MUMEER BY EROUND SURFACE ELEVATION -

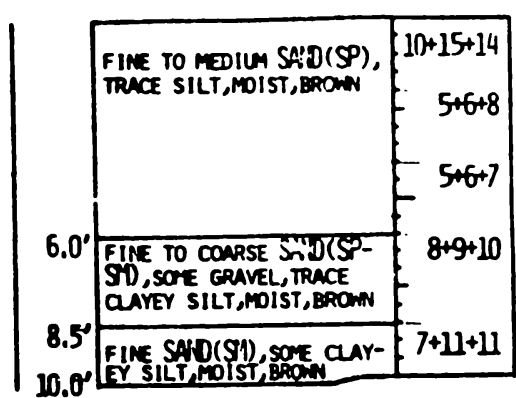

Dotron of DoRine $010.0^{\circ}$

SORIMG COMPLETED 10-30-80

\section{MATER LEVEL READIMGS}

\section{EncounterED wore}

uPon comprition nove to $6.0^{\circ}$ Q

MATER -

AFTER -

caven ar -

martued on comprion

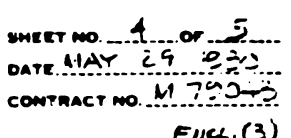

Elice. (3)
Stiree ; of ;

Migu's inn ( 3

CDERR NOTES

Number in right hand coluen indicates the number of bluss requitred to drive a. Inch 0.D., 1-3/8 Inch 1.D. sampling spoun thr wugn three o inch intervale or as indicated, uaing a 160 pound hamer ialling 30 inches, ording to ASTM D-1586.

Claseification of eoll is by visual inspection end is in accordance with the unifled wil classitication sustea. Symbols in par elltheses are

Boring foreman: B. Spierenburg

key to abbreviactions and syabuls:

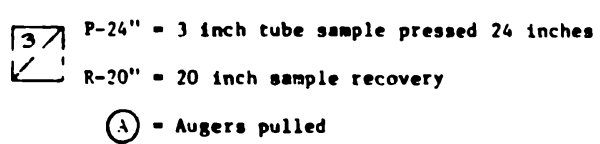

Bor 1 ngs mede by hollow sten auger.

bor ing locations selected in the fleld. Mo layout plans avallable. to elevations vare obcelned.

The otracification lines represent the approxieate boundary between so11 and rock types as deternined in the drilling and enopling operation. Some

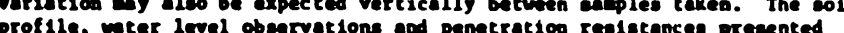

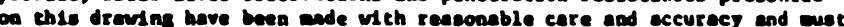

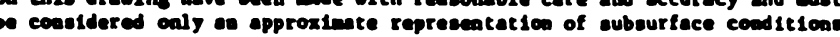
to to encountered at the particular location. 


\section{SCHNABEL ENCINEERINC ASSOCIIATES} A mort ssione coamenicon

CONSLLINCC CEOTECHNICAL ENCNEERS

Soptember 22, 1920

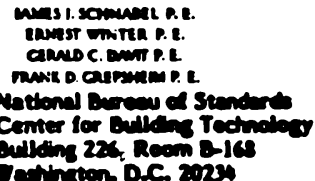

Tentingten DC. 2023

Propet

Texting Services for Mobile Home,

Ancherage Project, Report for Site "Co", Brown Stution Road, Upper M7sous?

Artur Dr. Fellix Y. Yoked

Gentlemen

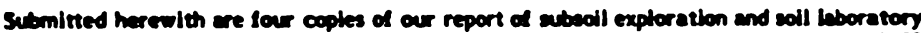
testine for Site "C". These services heve been provided under your Purchese Order NB 79 - MAAA 9922, doted April 18, 1979.

Site

The teat alte for this aries of tests was a wooded trect domb Brown Stution Road near Upper Merlboro, Maryland Solls encountered were silty clays overlying sends,

Fied Teating

Pour soll test boring were drilled by our acbsidiary, Foundation Test Service, me. to a depth of coovi 5 so 3.5 feet each. Two 3 inch undisturbed tube samples of silty clay were recovered in Borings IC and ZC. Borings were located in a roughly diamond pattorn, with a lone axt of about 75 feet, generally perpendicular to Brown Station Road.

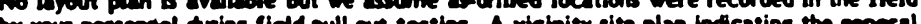
by your personved drine field pull our tesing

Group symbols after the description of solls ze in cocordence with the Unilied Soll Clevaltication System and were based on visual exernination of semplet. The gystem
National Bureau of Staiderts

Sepiember 22, 1920

The standard penetration resistance, or $\mathbf{N}$ value, indicates the penetration

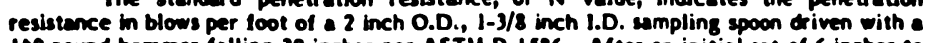
140 pound hammer lalling 30 inctes per ASTM D-1 1526. After on initial set of 6 inches io ascure the sample ampler an additional 12 inches is usually taken as the $N$ value. The penetration for each 6 inches of dive is strown in the right hend column of the test boring loge.

Groundwater was observed in all of the borings upon completion of trilling at

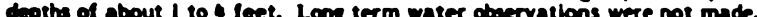

\section{Soll Leboratory Testing}

The laboratory testing progiam was assizned by your office. Soil taboratory test results are summarized in Enclosure (2). Natural moisture content, natural density and epecific gravity tests were conducted on ino tube samples. Sieve andyes were canducted to determine the orain slze oradotion, and a triaxial comprewion and

The test results indicate that the natural soil tested are typically a silty clay or the sandy silty clay with trace to some fine or fine to coarse sand, with organic matter, corresponding to CL classification according to ASTM D-2487. Viswal classificatione indicate that solls described as iive silty and are also present.

Natural moisture contents ianged from about 23\% $10.0 \%$ with natural dry demeithe between abour 81 and 100 pcl. Specific gravities 012.36 and 2.34 were recorded in unconfined compreation test recorded an uncontined compressive strength of $q_{2}=1,933$ pal at $6.7 \%$ strain.

Soll amples remabing will be retained until November 6, 1980 and then dixcarded unbew other dilaposition is requested Ve upprecinte the cpportunity to be of continued service for this project. Ploese call 4

Very truly yours,

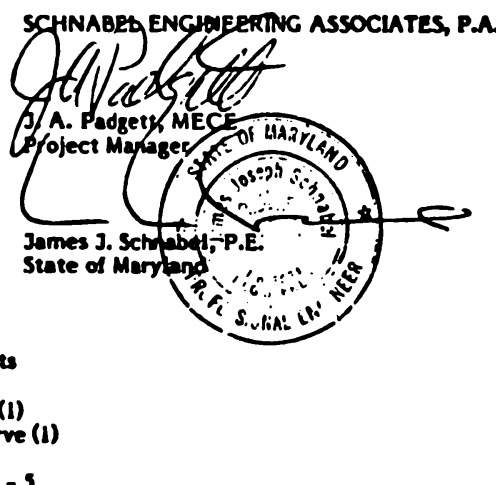


Enclosure (2)

Contract No. M79043

\begin{tabular}{|c|c|c|c|c|c|c|c|c|c|c|c|c|}
\hline \multirow{3}{*}{$\begin{array}{l}\text { Boring } \\
\text { Mo. }\end{array}$} & \multirow{3}{*}{$\begin{array}{l}\text { Seaple } \\
\text { Depth }\end{array}$} & \multirow{3}{*}{$\begin{array}{l}\text { Saiple } \\
\text { Type }\end{array}$} & \multirow{3}{*}{$\begin{array}{l}\text { Deocription } \\
\text { of Soll } \\
\text { Specimen }\end{array}$} & \multicolumn{9}{|c|}{ SURSURY OF SOIL LABORATORY TES } \\
\hline & & & & \multirow{2}{*}{\begin{tabular}{|c|} 
Percent \\
Passing \\
No. 200 \\
Sieve
\end{tabular}} & \multicolumn{2}{|c|}{$\begin{array}{l}\text { Acterbers } \\
\text { Limits }\end{array}$} & \multirow{2}{*}{$\begin{array}{l}\text { Netural } \\
\text { Molature } \\
(x)\end{array}$} & \multicolumn{2}{|c|}{$\begin{array}{l}\text { Natural } \\
\text { Dennitey } \\
\text { (pcf) }\end{array}$} & \multirow{2}{*}{$\begin{array}{l}\text { Spec1r1c } \\
\text { Gravity }\end{array}$} & \multirow{2}{*}{$\begin{array}{c}\text { Soll } \\
\text { Parameters }\end{array}$} & \multirow[b]{2}{*}{ Remerks } \\
\hline & & & & & \begin{tabular}{|l|l}
$L$ & $P L$ \\
\end{tabular} & $4 \mathrm{PI}$ & & thet & \begin{tabular}{|l|} 
Dry \\
\end{tabular} & & & \\
\hline IC & $2 \mathbf{2}^{\prime}$ & $\begin{array}{l}3^{3 \prime \prime} \\
\text { Tube }\end{array}$ & $\begin{array}{l}\text { SILTr CLAY (CL), trace } \\
\text { fine gand vith organic } \\
\text { meter, gray }\end{array}$ & 89.1 & 3920 & 019 & 40.2 & 113.6 & 81.1 & 2.56 & $\mid \begin{array}{l}q u-1933 \text { psf } \\
e \in-6.72 \\
\text { Brittle Faillure }\end{array}$ & $\begin{array}{l}\text { See: Gradation and } \\
\text { Unconfined Com- } \\
\text { pression Curves }\end{array}$ \\
\hline $2 c$ & $2^{\prime}-6^{\prime}$ & $\begin{array}{l}\text { 3" } \\
\text { Tube }\end{array}$ & $\begin{array}{l}\text { SILTY CLAY (CL), oome } \\
\text { frre to coarse sand } \\
\text { with orgenic matter. } \\
\text { gray }\end{array}$ & 72.2 & $35 \mid 20$ & o 15 & 23.1 & 123.5 & 100.3 & 2.54 & $\begin{array}{l}0=19^{\circ} \\
c=0.7 \mathrm{ksf}\end{array}$ & $\begin{array}{l}\text { Sce: Gradnction and } \\
\text { Triaxis Compres- } \\
\text { sion Curves }\end{array}$ \\
\hline $3 c$ & $2^{\prime}$ & Jar & $\begin{array}{l}\text { SILTY CLAY (CL), some } \\
\text { fine sand with organic } \\
\text { watter, gray }\end{array}$ & 82.6 & $38 \mid 22$ & 216 & 27.6 & - & - & - & - & - \\
\hline Ac & 3.5' & Jar & $\begin{array}{l}\text { Fine sanoy C.mytzy } \\
\text { (CL-ML), with organic } \\
\text { matter, gray }\end{array}$ & 61.1 & $2 i \mid 20$ & 7 & 23.9 & - & - & - & - & $\begin{array}{l}\text { See: Gradation } \\
\text { Curve }\end{array}$ \\
\hline
\end{tabular}

Motees

1. Soll teat in eccordance with applicable ASTM Standardo.

4. Key to abbreivationa: LL-Liquid Lialt: PL-P1astic Limit; PI-P1asticlty Index; $q_{u}$-Unconf ined Compresive Strength; C-Apparent Cohe
Priction Angle; $t$-Axlal Strain.

2. Soll claesification eymole are in accordance with Unified soll clasenfication syotem. based on teating Indicated and vioual ideat $1-$
fication.

3. Soll teats were conducted by L. Trullo, T. Chariton and $\mathrm{E}$, Somenbers.

3. Vioual identification of semples is in eccordence with the ayoten uned by thio tirn. 

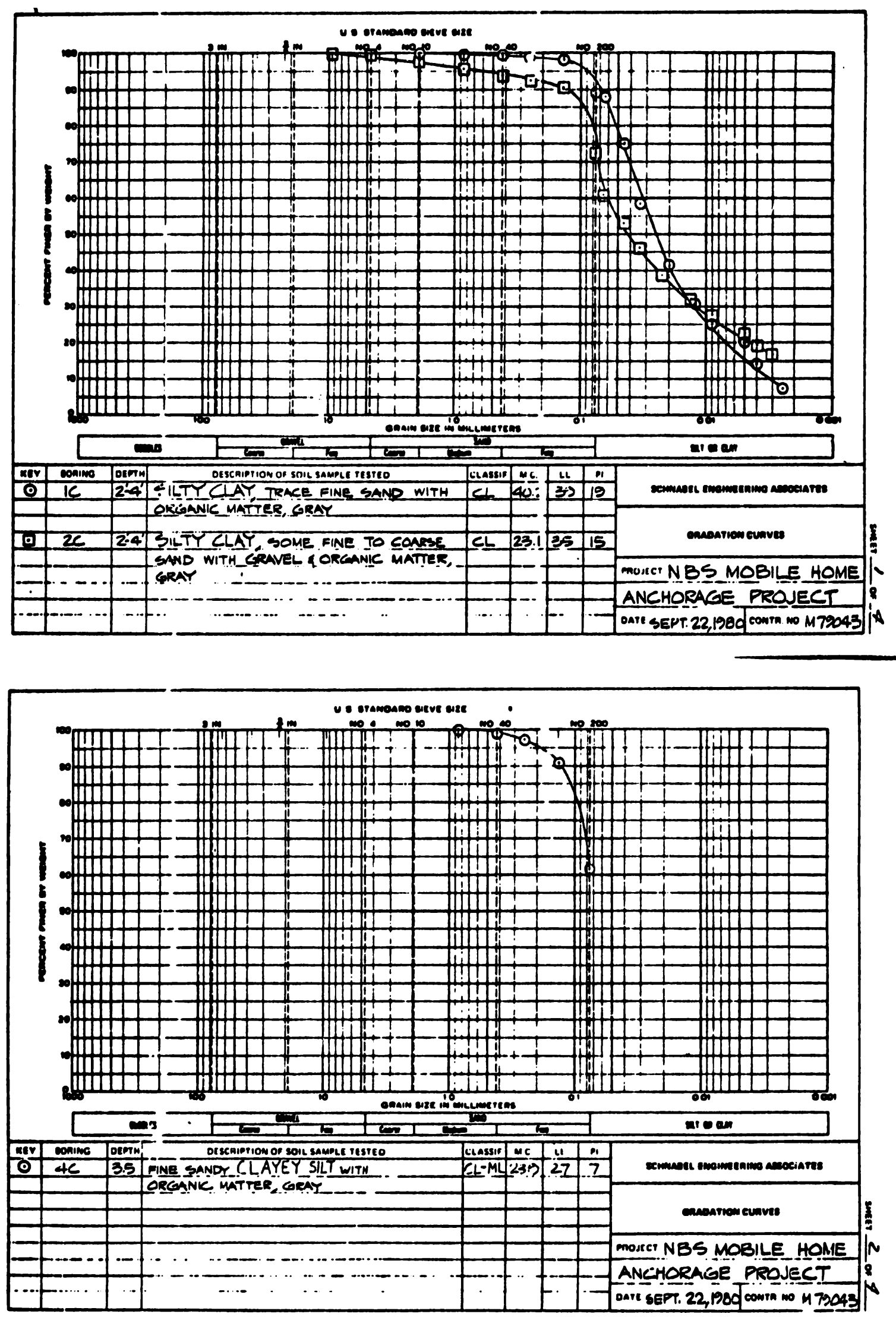
encir|
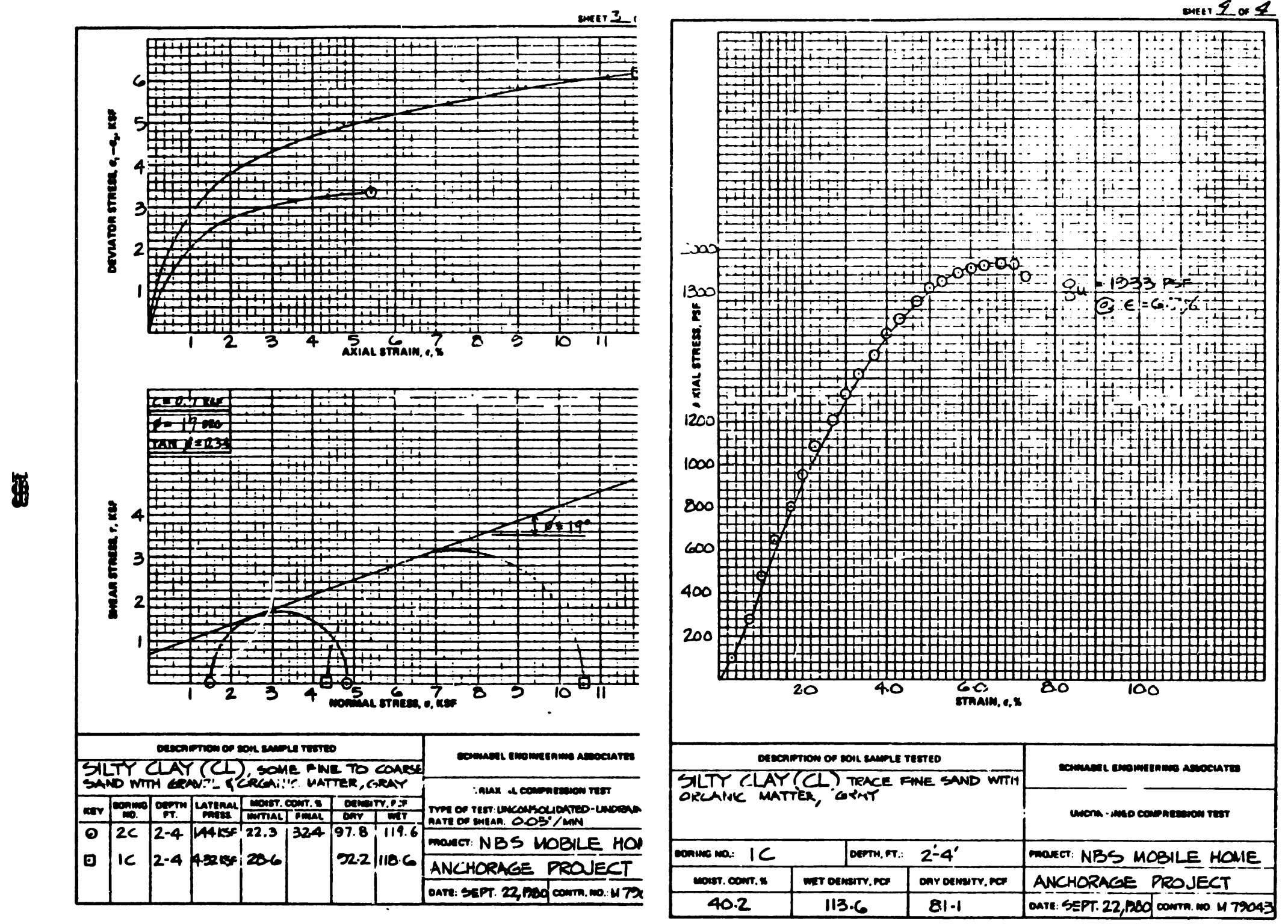
Enclosure (3)

Contract No. M79043

SUBSOIL INVESTIGATION REPORT

Test Boring Report

Borings IC - 4C, Sheets I -

General Notes, Sheets

Description of Subail Invertigation Procedures:

1. Test Borings Using Contimuous Flight (Mecherical) Ausers

Tett borings were edvenced wing $4-1 / 2$ inch continuous flight solid augers which rotate into the soll and bring cultings to the surlace. The augers are withdrawn from the

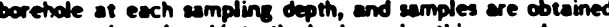

2. Standerd Penetration Teats

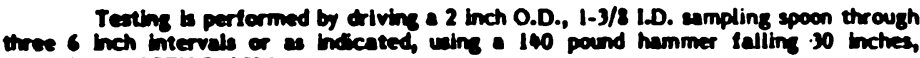
cocoring to ASTM D-1 sek.

1. Berter Lecations and Gredes

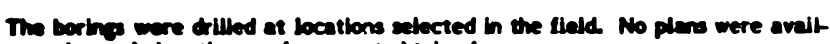

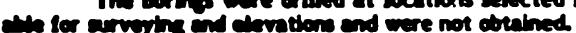

SCHMABEL EN GINETRING ASSOCIATES

CONSULTING ENGINEERS

coil mecmamics amo roumoation

GROUNO SURFACE ELEVATION

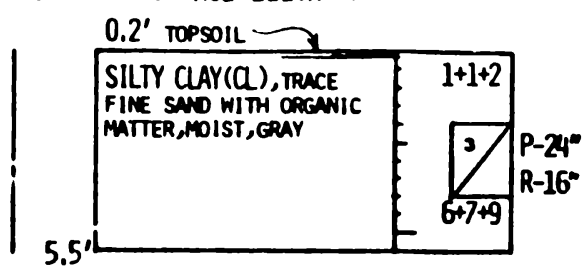

BtTon of Boring $85.5^{\circ}$

DORING COMPLETED $11-21-79$

MATER LEVEL READIMGS

ENCOUNTERED NONE

UPON COMPLETION $1.5^{\circ}$

MATER -

CAVEd AT - -

EMCOUTERED MONE
UPON COMPLETION 1.5'
MATER -
$\ldots$ CANED AT -....

meer No $1 .-5$

comrnacr mo. M. 29043

ENCL, (3) 
SCHNABE ENGINEERING ASSOCIATES

CONSULTING ENGINEERS

DOH MECMANICS AND ROWWOAT eneer mo. 2 . . of 5 Care SEPT 22, 1980? cowrnacr mo. M. 79043

ENCL. (3)
SCHNABEL ENGINEERING ASSOCIATES CONSULTING EMGINEERS sweet no _... 3 or 5 DATE SEPT 22 , ISOX contanact no. M.7.2043

ENCL. (3)
DORING NUMBER $x$ CROUND SURFACE ELEVATION

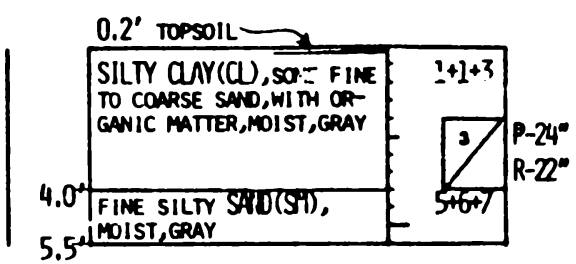

Botron of boring $25.5^{\circ}$

BORING COMPLETED 11-21-7?

MATER LEVEL READIMGS

ENCOUNTERED NONE

UPON COMPLETION $1.0^{\circ}$

MATER -

AFTER -
BORING MUMBER $3 C$ GROUND SURFACE ELEVATION

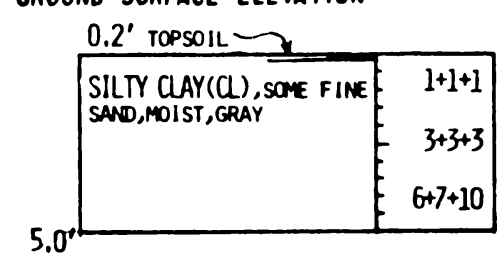

BOTTOM OF BORIRE a $5.0^{\circ}$

BORING COMPLETED $\quad 11-21-79$

WATER LEVEL READINGS

ENCOUNTERED NONE

UPON COMPLETIOM $4.2^{\prime}$

WATER -

AFTER -

CAVED AT

CAVEd AT - 
SCMNABD ENGINEJRING ASSOCIATES

CONSULTME EMGINEERS

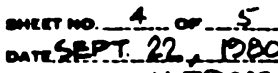

cowranct mo. M 72093

ence. (3)
Sheet 3 of 5

Enclosure (3)

GENERAL NOTES

1. Number In right hand column indicates the number of blows required to tive $22 \mathrm{inch}$ O.D., 1.3/8 inch 1.D. ampling spoon through three 6 inch intervals of as hedicsted, wing a 140 pound hammer falling 30 inches, eccording to ASTM D-1586.

2. Ciassification of soil is by visual inspection and is in eccordance with the Unifled Soil Classification System. Symbols in parentheses are estimated Unified Soll Classi-

3. Boring foreinare R. Stioham

BORIMG MUMAER LC EROUNO SUnFACE ELEVATION

$0.2^{\prime}$ TOPSOIL $\rightarrow$

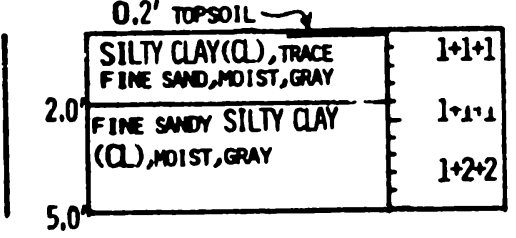

Dotron of Borino $95.0^{\prime}$

DORING COMLETED $11-21-79$

WATER LEVEL, HEADIWGS

ENCOUNTERED MaVe

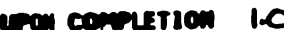

maten -

AFTER -

CAVED AT -

4. Key to abbreviations and symbols:

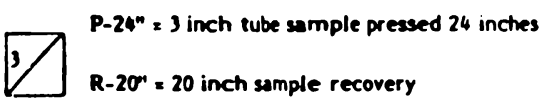

9. Borings made by mechanical auger (without the we of drilling water).

6. Hor ing locations selected in the field. No layous plans available. No elevations were

7. The stratifiration lines represent the approximate boundary between soil and rock

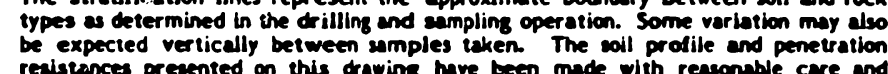
reaistances presented on this drawing have been made with reasoneble care and cocuracy and must be considered only an approximate 


\section{APPENDIX B}

\section{Test Results}

\section{B.1. Introduction}

The test results are presented in a series of six tables. The data In the tables were taken from $x-y$ plots produced electronically in the fleld, except that in tests ST1 to ST12 the data were recorded manually. Anchors of several makes were used in the study. Since it was not the intent of this study to compare the performance of different products, anchors of different makes are identifled by letters only. The swivel anchors were inserted by a percussion tool. The time it took to install the anchors is identified in the footnotes.

B.2 Symbols Used in the Tables

Static rest results:

Test Number Designations:

$$
\begin{aligned}
\text { ST } & =\text { Silty Site } \\
\text { SD } & =\text { Sandy Site } \\
C & =\text { Clay Site }
\end{aligned}
$$

\section{Test Location:}

Coordinates in location maps in Appendix $\bar{A}$

\section{Anchor Type:}

H-6 = 6-inch single helix anchor

D-4 = 4-inch double hel1x anchor

$\mathrm{H}-3=3-1$ ach single helix anchor

$\mathrm{p}-10=10 \times 13 / 4$ in. p1pe anchor

P-6 = $61 / 2 \times 11 / 4$ in. pipe anchor

AH-6 = 6-1nch arrowhead anchor 


\section{Anchor Inclination:}

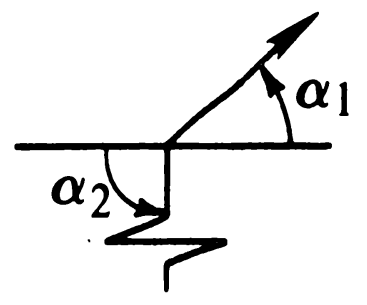

\section{Loading:}

SM = Static monotonic

SUR $=$ Static monotonic with several unloading and reloading cycles

$C P=$ Creep test

Soil Condition:

$M=$ Moist

$\mathrm{W}=$ Wet

$\mathrm{S}=$ Submerged

Other Symbols:

STP = So11 Test Probe reading, in-1b

$\mathrm{T}_{1}=$ Installation torque, $\mathrm{ft}-1 \mathrm{~b}$

$\mathrm{P}_{2 \mathrm{v}}=$ Load at 2-inch vertical displacement, $1 \mathrm{~b}$

$\mathrm{P}_{4 \mathrm{H}}=$ Load at 4--1nch horizontal displacement, 1b

$Q_{\mathrm{u}} \quad=$ U1timate load capacity, $1 \mathrm{~b}$

$\Delta_{u}=$ Anchor head displacement in the direction of pull at $Q_{u}$, In

$\mathrm{R}_{85}=$ Reloading modulus at 85 percent of $Q_{u}, 1 \mathrm{~b} / \mathrm{in}$

$\mathrm{P}_{\mathrm{c}} \quad=$ Cyclic 1oad, 1b

$\mathrm{n} \quad=$ Number of cycles $\Delta_{1}, \Delta_{10}, \Delta_{100}, \Delta_{u}=\begin{gathered}\text { total anchor head displacement in 1st, 10th, 100th and last } \\ \text { cycle }\end{gathered}$ 
$R_{10}=$ Reloading modulus in i0th cycle, $1 \mathrm{~b} /$ in $\begin{aligned} Q_{u}^{\prime}= & \text { Ultimate load capacity determined by anchor pullout after completion } \\ & \text { of cyclic tests }\end{aligned}$ 


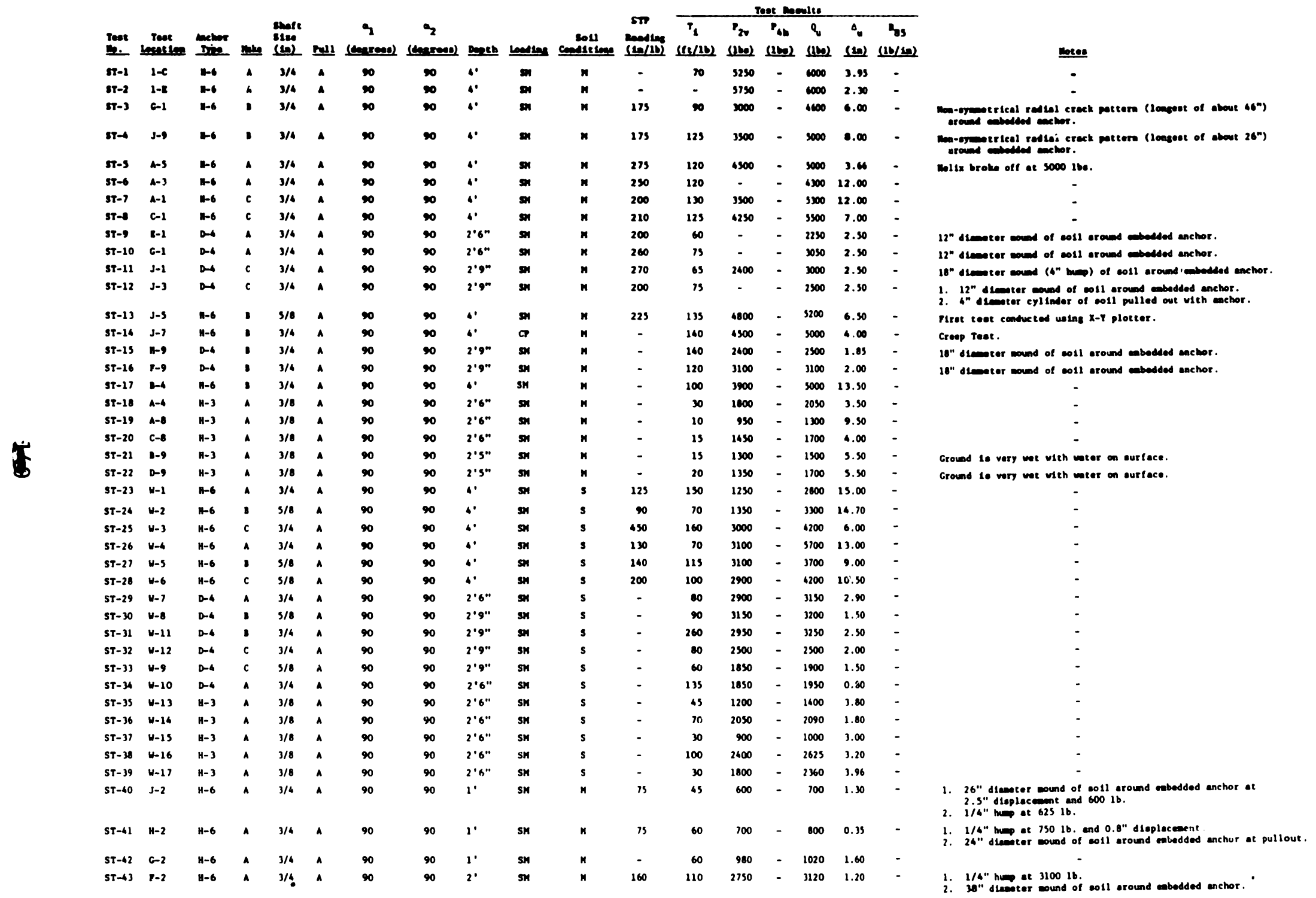




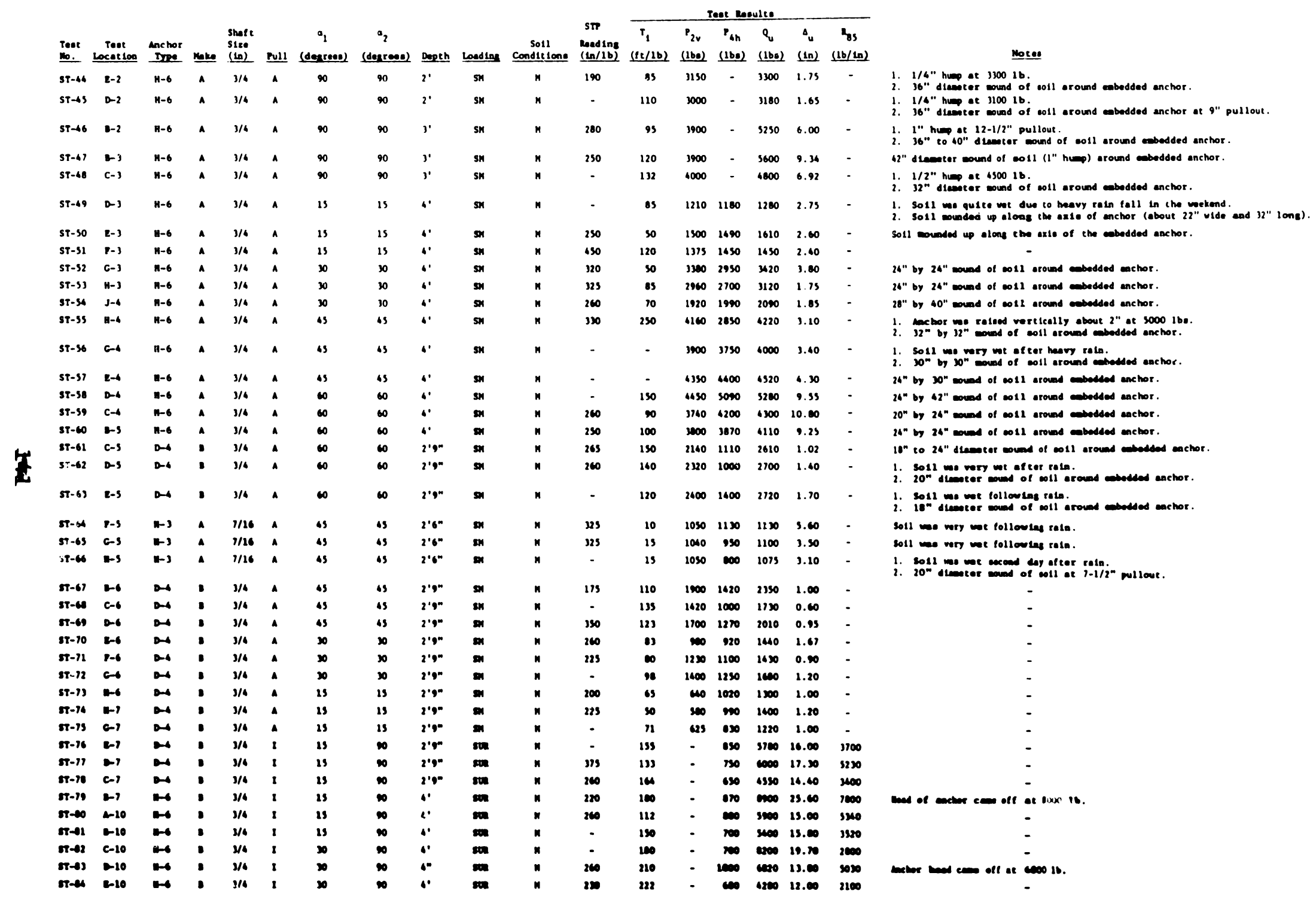




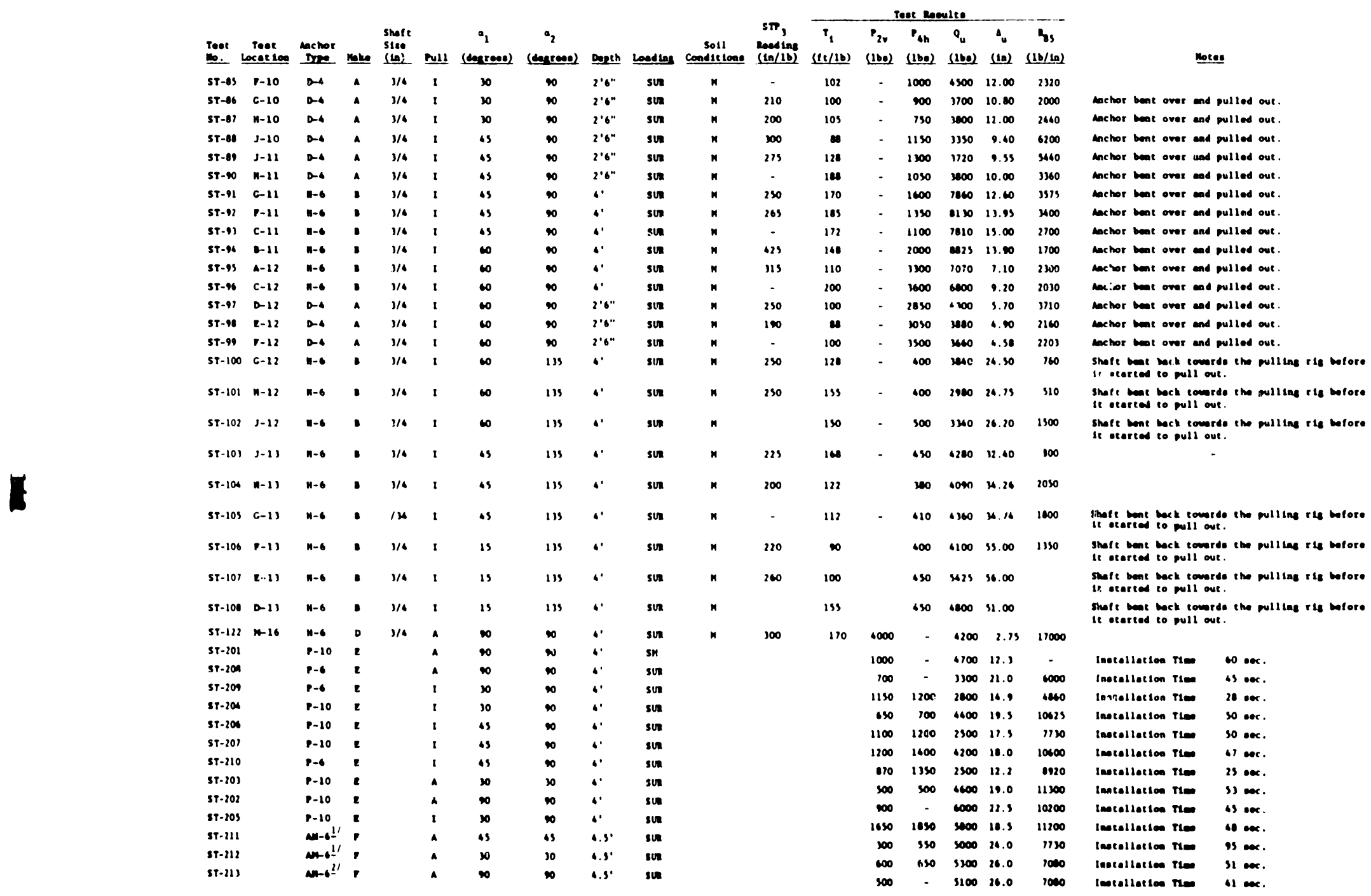


Table 1.2. Gyclic Toot Rosulte on site a (silty solle)

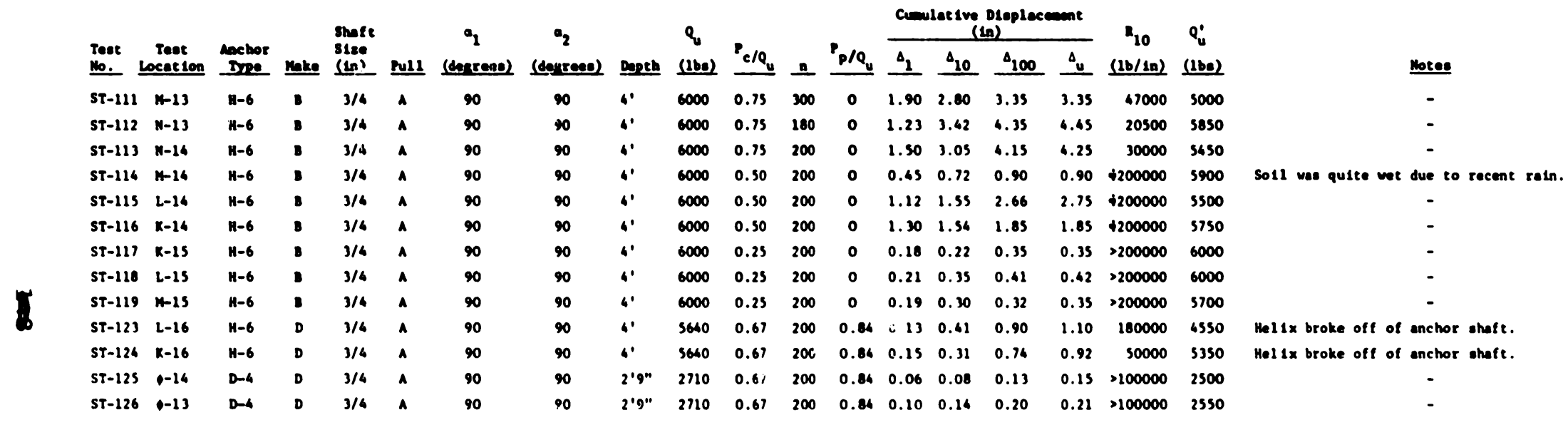




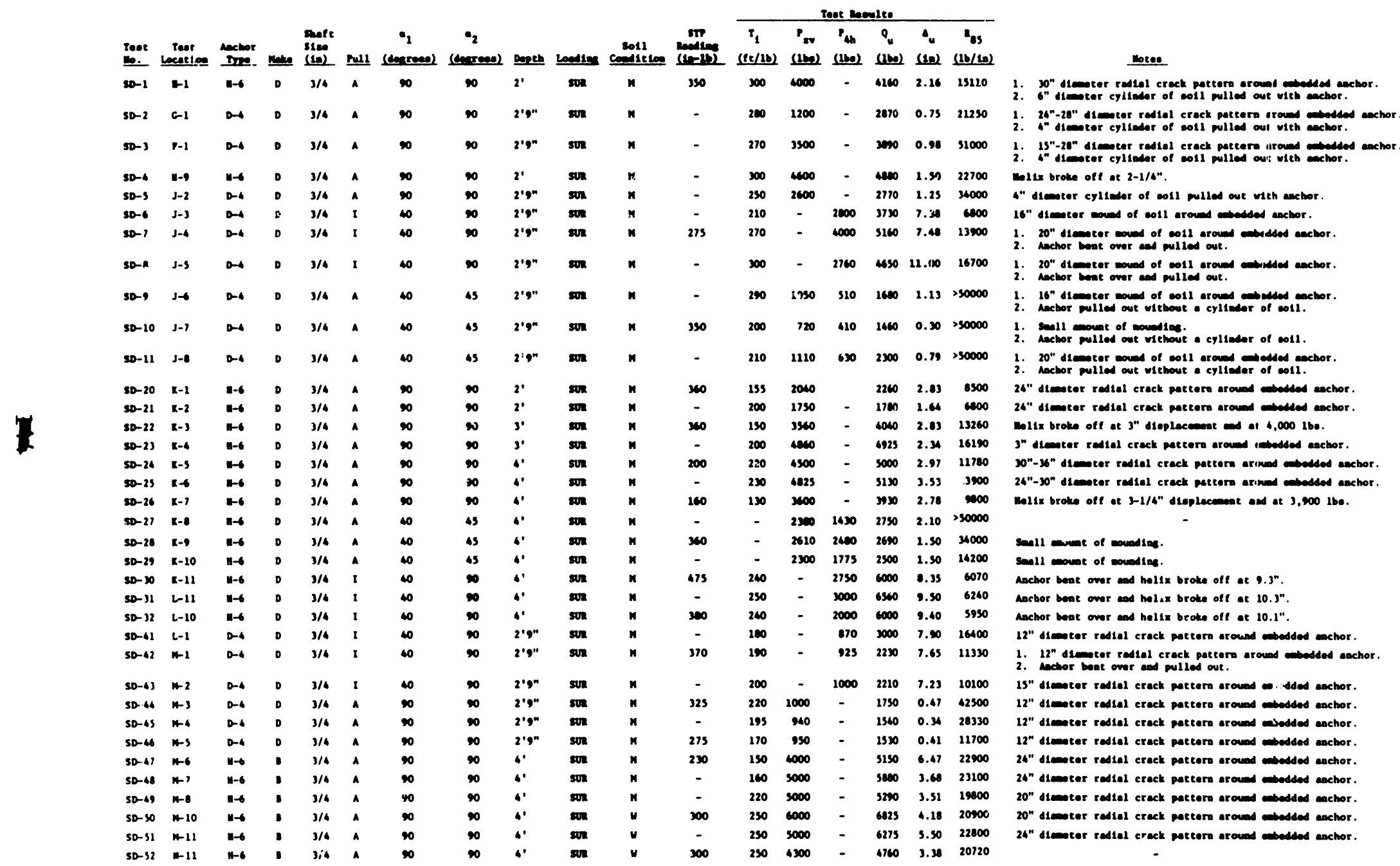




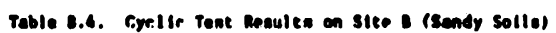

\begin{tabular}{|c|c|c|c|c|c|c|c|c|c|c|c|c|c|c|c|c|c|c|}
\hline \multirow[b]{2}{*}{ Teot } & \multirow{2}{*}{$\begin{array}{c}\text { Tear } \\
\text { Leceation }\end{array}$} & \multirow{2}{*}{ melor } & \multirow[b]{2}{*}{ nnen } & \multirow{2}{*}{$\begin{array}{l}\text { Shaft } \\
\text { gise } \\
\text { (la) }\end{array}$} & \multirow[b]{2}{*}{ sull } & \multirow{2}{*}{$\begin{array}{c}1 \\
\text { (consene) }\end{array}$} & \multirow{2}{*}{$\begin{array}{c}n_{2} \\
\text { (ceneren) }\end{array}$} & \multirow{2}{*}{\multicolumn{2}{|c|}{$\begin{array}{c}q \\
\text { Deosh (110) }\end{array}$}} & & \multirow[b]{2}{*}{ o/p } & \multicolumn{4}{|c|}{ 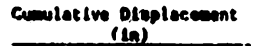 } & \multirow{2}{*}{$\begin{array}{c}R_{1 n} \\
(16 / \ln )\end{array}$} & \multirow{2}{*}{$\begin{array}{l}3: 0 \\
\text { (1be) }\end{array}$} \\
\hline & & & & & & & & & & & in & & $c_{1}$ & -10 & 100 & $\dot{\dot{y}}$ & & \\
\hline $80-12$ & H-9 & $D-6$ & D & $3 / 6$ & I & 40 & 90 & $2^{\prime} 0^{\prime \prime}$ & (A) & 0.15 & 280 & n & 3.87 & 4.51 & 3.46 & a.16 & 200000 & $6 \mathrm{~mm}$ \\
\hline $30-13$ & $n \rightarrow 0$ & 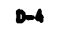 & D & $3 / 4$ & 1 & 10 & 90 & $2 \cdot 0^{\prime \prime}$ & A(A) & 0.73 & in & D & 5.20 & $1.2 n$ & - & • & 7600 & $\bullet$ \\
\hline $50-16$ & $n-1$ & $0 \rightarrow 6$ & D & $3 / 4$ & I & 10 & 90 & 2'9" & Ax 3 & 0.67 & - & 0.86 & - & - & - & - & - & $\bullet$ \\
\hline $80-15$ & n-6 & Da & D & $3 / 6$ & I & 10 & 90 & $2 \cdot 0^{\prime \prime}$ & 4663 & 0.67 & • & 0.86 & - & - & - & • & - & • \\
\hline $80-16$ & M-S & and & D & $3 / 4$ & 8 & 40 & 90 & 2'0" & W627 & 0.15 & 300 & 0 & 6.80 & 3.40 & 0.60 & 1.40 & $10 \mathrm{~mm}$ & 2000 \\
\hline $80-17$ & $n-6$ & $0-6$ & D & $3 / 4$ & t & 40 & 90 & 2'9" & 3627 & 0.75 & 200 & 0 & 4.21 & 4.12 & 5.65 & 3.13 & 180000 & 6200 \\
\hline $80-16$ & M-3 & 0.6 & 0 & $3 / 4$ & I & 40 & 90 & 2'g" & 3170 & 0.67 & 200 & 0.04 & 0.75 & 0.95 & 1.40 & 1.67 & $27 n 000$ & 6700 \\
\hline 80-19 & H-2 & $0-4$ & 0 & $3 / 6$ & I & 40 & 10 & $2 \cdot 9 "$ & סוני & 0.67 & 200 & 0.86 & 0.80 & 1.10 & 1.55 & 1.72 & 200000 & 3asn \\
\hline $80-33$ & L-9 & H-6 & 0 & $3 / 4$ & $A$ & 90 & 90 & 40 & 3675 & 0.75 & 300 & 0 & 0.05 & 1.31 & 3.30 & 3.63 & 23000 & 6700 \\
\hline $80-36$ & L-B & $\mathrm{H}-6$ & D & $3 / 4$ & $A$ & 90 & 90 & $4^{\circ}$ & 3475 & 0.75 & 200 & 0 & 1.52 & 2.18 & 4.63 & 5.90 & 20500 & Cson \\
\hline s0-35 & $\lfloor-7$ & HeS & D & $3 / 6$ & A & 90 & 90 & $4^{\circ}$ & 3060 & 0.67 & 200 & 0.86 & 0.25 & 0.60 & 1.57 & 2.16 & 12360 & $s 100$ \\
\hline $80-36$ & $L-6$ & H-6 & D & $3 / 4$ & A & 90 & 90 & $6^{\circ}$ & 3860 & 0.67 & 200 & 0.84 & 0.20 & 0.57 & 1.97 & 2.50 & 205000 & 6000 \\
\hline $80-37$ & L-S & $M-6$ & D & $3 / 6$ & $\mathrm{I}$ & 40 & 90 & $4^{\circ}$ & 6675 & 0.75 & 121 & 0 & 8.85 & 9.05 & 12.27 & $\cdot$ & 16500 & - \\
\hline $8 D-30$ & $L-4$ & $H-6$ & D & $3 / 4$ & I & 10 & 90 & $6^{\circ}$ & 4675 & 0.15 & 200 & 0 & 1.52 & 8.22 & 10.22 & 21.51 & 28700 & - \\
\hline $80-39$ & $L-3$ & H-6 & D & $3 / 4$ & 1 & 40 & 90 & 40 & 5200 & 0.67 & 200 & 0.86 & 0.23 & i..s & 1.15 & 1.67 & 20700 & - \\
\hline $80-40$ & L-2 & M-6 & D & $3 / 6$ & $t$ & 10 & 90 & $4^{\circ}$ & 5200 & 0.67 & 200 & 0.86 & 0.33 & 0.75 & 1.82 & 2.29 & 13500 & - \\
\hline $80-53$ & N-9 & $0-4$ & D & $3 / 6$ & A & 90 & 90 & 2'9" & 1627 & 0.67 & 200 & 0.86 & 0.01 & 0.07 & 0.24 & 0.35 & $=50000$ & 2330 \\
\hline 8D-56 & $M-8$ & $0-4$ & $D$ & $3 / 4$ & A & 90 & 90 & 2'9" & 1627 & 0.67 & 200 & 0.84 & 0.03 & 0.08 & 0.37 & 0.25 & 2500000 & 2320 \\
\hline
\end{tabular}

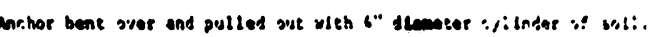

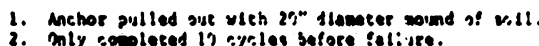

Anchor pulled ous before preload ves ceasehet.

anchore bent overe end pulled out.

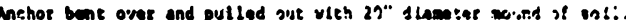

Anchor bene over and pulled out vitin o :yllndar it sn!:

Anchor bent over aod pulled ous ultin a c.jllinser if wo :

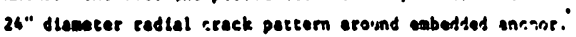

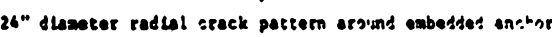

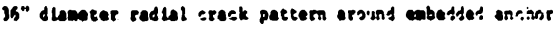

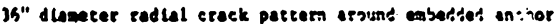

Hellix broke oft at $n-121$.

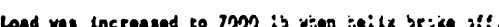

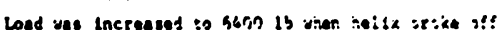

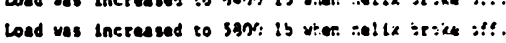

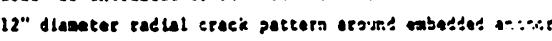

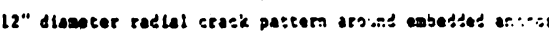


Table 8.5. Static toot Resules on Site $C$ (Clayey soile)

\begin{tabular}{|c|c|c|c|c|c|c|c|c|c|c|c|c|c|c|c|c|c|c|}
\hline \multirow[b]{2}{*}{$\begin{array}{l}\text { Teat: } \\
\text { He. }\end{array}$} & \multirow[b]{2}{*}{$\begin{array}{c}\text { Teat } \\
\text { becatiop }\end{array}$} & \multirow[b]{2}{*}{$\begin{array}{c}\text { Anchor } \\
\text { Iype }\end{array}$} & \multirow[b]{2}{*}{ Nan } & \multirow[b]{2}{*}{$\begin{array}{l}\text { Shaft } \\
\text { size } \\
\text { (12i) } \\
\end{array}$} & \multirow[b]{2}{*}{ Pull: } & \multirow[b]{2}{*}{$\begin{array}{c}a_{i} \\
\text { (denrea) }\end{array}$} & \multirow[b]{2}{*}{$\begin{array}{c}a_{2} \\
\text { (dorreot) }\end{array}$} & \multirow[b]{2}{*}{ Depeth } & \multirow[b]{2}{*}{ Loediar } & \multirow[b]{2}{*}{$\begin{array}{c}\text { Soll } \\
\text { Conditson }\end{array}$} & \multirow[b]{2}{*}{$\begin{array}{c}\text { STP } \\
\text { Redding } \\
(\text { In/lib) }\end{array}$} & \multicolumn{6}{|c|}{ Teet Regulice } & \multirow[b]{2}{*}{ Sorees } \\
\hline & & & & & & & & & & & & $\begin{array}{c}T_{1} \\
(s s / 1 b)\end{array}$ & $\begin{array}{l}P_{2 v} \\
\text { (1bes) }\end{array}$ & $\begin{array}{l}P_{\text {oh }} \\
\text { (1) }\end{array}$ & $\begin{array}{c}Q_{u} \\
(160)\end{array}$ & $\begin{array}{l}s_{u} \\
(\ln )\end{array}$ & $\begin{array}{c}R_{85} \\
(1 b / 2 n)\end{array}$ & \\
\hline$c-1$ & $A-11$ & $H-6$ & $\mathbf{3}$ & $3 / 4$ & A & 90 & 90 & 11 & sin & $"$ & so. & so & 790 & - & 910 & 0.75 & - & 24" diameter mound of will arvund abbosted sains. \\
\hline c-2 & $A=10$ & $H-6$ & B & $3 / 4$ & $A$ & 90 & 90 & 2! & sur & 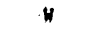 & - & ss & 1700 & - & 1730 & 2.75 & 12140 & Verv stithe asount of sounding. \\
\hline c-3 & A.9 & H-6 & - & 3/4. & A & 90 & 90 & $2 !$ & sUR & n & - & so & 1790 & - & 1850 & 3.50 & 10650 & تerv slight aacunt of goundtng. \\
\hline$c-6$ & $\mathbf{3 - 1 1}$ & $H=6$ & ! & $3 / 4$ & A & 90 & 90 & 3' & sur & H & - & 80 & 2750 & - & 3100 & 4.50 & $\$ 3700$ & 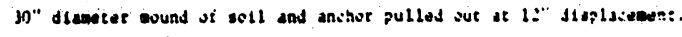 \\
\hline c-s & B-10 & M-6 & $B$ & $3 / 4$ & A & 90 & 90 & 3' & SLR & $n$ & - & $\infty$ & 2300 & - & 2850 & 4.00 & 22140 & Small mount of ooundins. \\
\hline c-6 & $8 \div 9$ & H-6 & B & $3 / 4$ & $A$ & 90 & 90 & 4. & suR & M & 100 & 100 & 2300 & - & 2800 & 9.00 & 12160 & 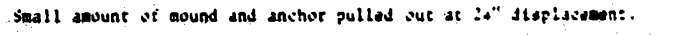 \\
\hline c-1 & $c-11$ & $H-6$ & - & 3/4. & A & 90 & 90 & 4. & suR & n & - & 90 & 3400 & - & 3830 & 5.00 & .7612 & 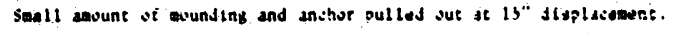 \\
\hline c-8 & c-9 & $\mathrm{H}=6$ & B & $3 / 4$ & A & 90 & 90 & $4^{\circ}$ & sur & M & - & 210 & 3300 & - & 3630 & 3.50 & 13700 & 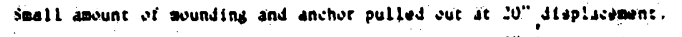 \\
\hline c-9 & D-11 & D -6 & D & 3/4 & A & 90 & 90 & 2'9" & ȘUR & H. & - & 105 & 1850 & - & 1900 & 1.00 & 13500 & 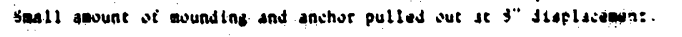 \\
\hline c-10 & $\mathbf{z}-\mathbf{1 1}$ & Da 6 & D & $3 / 4$ & a & 90 & 90 & 2'9"' & sun & H & 75 & 105 & L8so & - & 1900 & 2.50 & $\$ 2500$ & 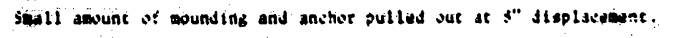 \\
\hline$c-11$ & $\mathbf{p}+11$ & De-4 & D & $3 / 4$ & $\boldsymbol{A}$ & 90 & 90 & 2'g" & suR & M & - & 10 & 2730 & - & 2000 & 4.00 & 16150 & Verv sodil amunt si avunding. \\
\hline C-12 & G.11 & $D-4$ & D & $3 / 4$ & 1 & so & 90 & 2'9" & sur. & M & 190 & 90 & - & 2500 & 2500 & 6.22 & $1+700$ & Anchor bent ower and pulles out. \\
\hline $0-13$ & $G-10$ & $0-4$ & D & $3 / 4$ & I & so & 90 & 2'9": & sup : & n & - & 110 & - & 2100 & 2.00 & 4.73 & 9000 & Anchor bent sver and pulted sut. \\
\hline$c-16$ & Pag. & $0-4$ & D & $3 / 4$ & $\mathfrak{t}$ & 40. & 90 & 2.9" & sux & $n$ & 125 & 73 & - & 1050 & 1800 & 8.00 & 1700 & Anctore bent over and pulled sut. \\
\hline$c-15$ & $0-9$ & $D=-4$ & D & $3 / 4$ & a & 45 & 45 & 2'9" & sor & $n$ & $\therefore$ & so & 1450 & 1300 & 2500 & 2.55 & 8500 & Slithe anc une of mounding. \\
\hline$c-16$ & $\mathrm{H}-1 \mathbf{1 0}$ & $D \rightarrow 6$ & o & $3 / 4$ & A & 45 & 45 & $2^{\prime \prime \prime \prime}$ & sug & $n$ & - & 73 & 2750 & 1400 & 1750 & 2.25 & 21:50 & Slight asune of gounding. \\
\hline$c-1)$ & $H-11$ & D $\rightarrow$ - & D & $3 / 4$ & $A$ & 45 & 45 & 2?:" & sur. & H & 120 & - & 1700 & 1600 & 1800 & 2.40 & 2230 & 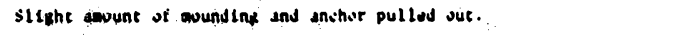 \\
\hline $0-18$ & J -10 & Ho6. & $B$ & $3 / 4$ & I & no & 90 & a & sur & n & - & 100 & - & 900 & 2500 & 16.68 & 13600 & Anehor bent over and pulled sut. \\
\hline$c-19$ & J-9 & $H=6$ & 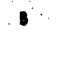 & 3/4 & 1. & 40 & 90 & 4. & sur & n & 100 & 130 & - & 100 & 3800 & 18.92 & - & 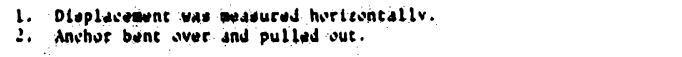 \\
\hline$c-20$ & H-9. & $M-6$ & $\Delta$ & $3 / 4$ & $\mathbf{1}$ & 40. & 90 & 4. & sur: & n & - & 150 & - & 100 & 3500 & 22.19 & $19: 20$ & - \\
\hline c-2! & G-8 & H-6 & : & $3 / 4$ & a & is & is & 4 & suR & 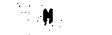 & 90 & 80 & 2350 & 2600 & 2700 & 6.02 & - & 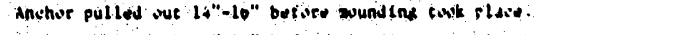 \\
\hline c-22. & $H=8$ & H-6 & . & $3 / 4$ & a & 49 & as & 6 & 8us & n & $\ldots$ & 35 & 2300 & 2450 & 2450 & 3,96 & 8500 & 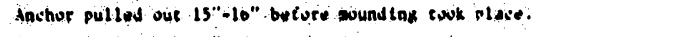 \\
\hline c-23 & G-7 & H-6 & B & $3 / 4$ & a & 45 & as & a. & sus & $n$ & 100. & 68 & 2000 & 2420. & 2650 & 5.37 & 9270 & 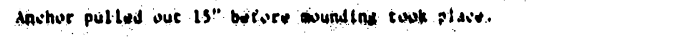 \\
\hline
\end{tabular}


Teble B.6. Cyclle Test Rooulte on site C (Clayey Solle)

\begin{tabular}{|c|c|c|c|c|c|c|c|c|c|c|c|c|c|c|c|c|c|c|c|}
\hline \multirow{2}{*}{$\begin{array}{l}\text { :est } \\
\text { so. } \\
\end{array}$} & \multirow{2}{*}{$\begin{array}{c}\text { Test } \\
\text { Locetion }\end{array}$} & \multirow{2}{*}{$\begin{array}{l}\text { Aachor } \\
\text { Dype }\end{array}$} & \multirow[b]{2}{*}{ 焉 } & \multirow{2}{*}{$\begin{array}{l}\text { Shoft } \\
\text { Shize } \\
\text { (1n) } \\
\end{array}$} & \multirow[b]{2}{*}{ Pull } & \multirow{2}{*}{$\begin{array}{c}21 \\
\text { (densees) }\end{array}$} & \multirow{2}{*}{$\begin{array}{c}a \\
\text { (destrees) }\end{array}$} & \multirow[b]{2}{*}{ Depth } & \multirow{2}{*}{$\begin{array}{l}Q_{u} \\
\text { (lbe) }\end{array}$} & \multirow{2}{*}{${ }^{P} / Q_{u}$} & \multirow[b]{2}{*}{$n$} & \multirow{2}{*}{$P_{p / Q_{u}}$} & \multicolumn{4}{|c|}{$\begin{array}{l}\text { Cumlet Ive Dieplacesent } \\
(\text { (nn) }\end{array}$} & \multirow{2}{*}{$\begin{array}{r}210 \\
(10 / 2 n) \\
\end{array}$} & \multirow{2}{*}{$\begin{array}{l}Q_{u}^{\prime} \\
\text { (1bo) }\end{array}$} & \multirow[b]{2}{*}{ Moles } \\
\hline & & & & & & & & & & & & & $s_{1}$ & $\Delta 10$ & $\Delta_{100}$ & $\Delta_{u}$ & & & \\
\hline$c-36$ & E-7 & H-6 & B & $3 / 4$ & A & 90 & 90 & $6^{\circ}$ & 3375 & 0.75 & 83 & 0 & 1.67 & 3.00 & - & 16.55 & 12100 & - & Reached the llalt of loading ro at $n=83$. \\
\hline c-:3s & E-6 & $n-6$ & : & $3 / 4$ & A & 90 & 90 & a' & 3575 & 0.75 & 190 & 0 & 0.48 & 0.60 & 2.67 & 7.20 & $\$ 50000$ & - & Roached the llate of looding rea at $n=190$. \\
\hline c-36 & E-S & $\$-6$ & B & 3/6 & A & 90 & 90 & $4^{\circ}$ & 3575 & 0.67 & 200 & 0.14 & 0.20 & 0.33 & 0.05 & 1.20 & $\$ \$ 0000$ & 4000 & - \\
\hline c-:? & D-6 & H-6 & - & $3 / 6$ & A & 90 & 90 & '. & 3573 & 0.67 & 161 & 0.14 & 0.30 & 0.90 & 5.00 & 16.00 & 9000 & - & 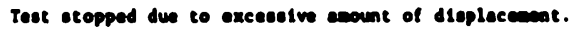 \\
\hline$c-39$ & C-i & 0.6 & D & $11 / 16$ & a & 90 & 90 & 2'9" & 2670 & 0.73 & 200 & 0 & 0.25 & 0.40 & 1.23 & 1.52 & $\$ 100000$ & 2900 & - \\
\hline C-32 & c-4 & $0-6$ & D & $21 / 16$ & a & 90 & 90 & 2'9" & 2670 & 0.75 & 200 & 0 & 0.10 & 0.23 & 1.00 & 1.07 & $\$ 100000$ & 2100 & - \\
\hline c-33 & Da- & 0.6 & D & $11 / 16$ & A & 90 & 90 & 2'9" & 2670 & 0.67 & 630 & 0.04 & 0.10 & 0.26 & 1.02 & 10.00 & 20000 & - & - \\
\hline c-36 & $D-8$ & $0-6$ & D & $18 / 16$ & A & 90 & 90 & 2'9" & 1670 & 0.67 & 200 & 0.86 & 0.02 & 0.06 & 0.13 & 0.18 & $>100000$ & 2200 & - \\
\hline$c-33$ & $A-6$ & $H=6$ & 8 & $3 / 6$ & I & 40 & 90 & $4^{\circ}$ & 2740 & 0.75 & 200 & 0 & 10.30 & 10.90 & 12.05 & 13.53 & 9000 & 3400 & - \\
\hline$c-36$ & 8-5 & $0-6$ & D & $11 / 16$ & I & 40 & 90 & 2'9" & 1665 & 0.75 & 69 & 0 & 0.90 & 10.45 & - & 15.90 & 3500 & - & Roeched the llate of laediag rec at a - 69 . \\
\hline c-37 & A-6 & 0.6 & D & $11 / 16$ & 1 & 10 & 90 & 2'9" & 2665 & 0.15 & 41 & 0 & 11.60 & 23.60 & - & 17.50 & 3700 & - & reactiod the llate of loeding ree ot $n$ - 41 . \\
\hline$c=30$ & $8-3$ & A-6 & B & $3 / 6$ & 1 & 40 & 90 & $6^{\circ}$ & 3650 & 0.75 & 126 & 0 & 13.20 & 16.05 & 20.00 & 21.75 & 40000 & - & - \\
\hline c-39 & $A-2$ & 0.4 & D & $11 / 16$ & 1 & 40 & 90 & 2'9" & 1670 & 0.67 & 200 & 0.84 & 1.60 & 2.15 & 3.70 & 6.30 & 3100 & 2100 & - \\
\hline$c-40$ & E-2 & B-6 & B & $3 / 4$ & 1 & 60 & 90 & $\omega^{\circ}$ & 3630 & 0.67 & 200 & 0.84 & 1.50 & 2.10 & 4.20 & 6.80 & 12000 & - & - \\
\hline$c-41$ & $D-1$ & $\mathrm{H}=6$ & $B$ & $3 / 4$ & 1 & 40 & 90 & $4^{\circ}$ & 3650 & 0.67 & 200 & 0.86 & 0.91 & 1.52 & 3.65 & 6.21 & 12000 & 3000 & - \\
\hline C=6? & $z-1$ & $D-6$ & D & $11 / 16$ & 1 & 60 & 90 & 2'g" & 1670 & 0.67 & 200 & 0.84 & 1.36 & 1.80 & 2.95 & 3.45 & 2100 & 2100 & - \\
\hline
\end{tabular}


1. PUBLICATION OR REPORT NO. NBS BSS 142
2. Porforming Orgen. Report Nod J. Publteation Uate

May 1982

4. TITLE AND SUBTITLE

Load-D1splacement Characterist1cs of Shallow Soll Anchors

5. AUTHOR(S)

Felix Y. Yokel, Riley M. Chung, Frank A. Rankin and Charles W. C. Yancey

6. PERFORMING ORGANIZATION (II joint or other thon NBS, see instructions)

7. ContracedGrant No.

MATIONAL OUREAU OF STANDAROS

DEPARTMENT OF COMMERCE

waShIMGTON, O.C. 20234

8. Type of Repore \& Period Covered Final

9. SPONSORING ORGANIZATION NAME AND COMPLETE ADDRESS (Street, City, Stote, ZIP)

Office of Policy Development and Research

U.S. Department of Housing and Urban Development

Washington, DC 20410

10. SUPPLEMENTARY NOTES

Library of Congress Catalog Card Number: 82-600509

[] Document describes a computer program; SF-185. FIPS Software Summary, is attached.

11. ABSTRACT (A 200-word or less foctual summory of most significont information. If document includes o significont bibliogrophy of llteroture survey, mention it here)

Tests on shallow soll anchors, commonly used by the mobile home industry, Including 6-in single helix and 4-in double helix anchors as well as three types of swivel anchors, were conducted on three sites: a silty site, a sandy 8ite, and a clay site. Test variables included direction of anchor installation; direction of loading; anchor depth; slze of anchor plate; and cyclic load effects. The effect of these test varlables on load-displacement characteristics, measured at the anchor head, is investigated. It 18 concluded that on most sites the anchor types tested, when installed in accordance with present Industry practice for moblle home tledown systems, did not deliver the anchor performance required in present standards. It 18 recommended that minimum load capac1ty requirements for anchors be walved; that all anchors be preloaded to 1.25 times the design load; and that one anchor per mobile home, or three anchors per site if 8011 conditions are uniform, be preloaded to 1.5 times the design load.

12. KEY WORDS (Six to twelve entries; olphobetical order; copitalize only proper nomes; ond separote key words by semicolons) anchors; cyclic loading; field testing; flood forces; foundations; load capacity; mobile homes; soil anchors; soil mechanics; stiffness; wind forces

\section{AVAILABILITY}

Rjunlimited

$\square$ For Official Distribution. Do Not Release to NTIS

$8]$ Order From Superintendent of Documents, U.S. Government Printing Office, Washington, D C 20402.

Order From National Technical Information Service (NTIS), Springfield, VA. 22161
14. NO. OF PRINTED PAGES

\section{3}

15. Price

$\$ 6.50$ 


\section{NBS TECHNICAL PUBLICATIONS}

\section{PERIODICALS}

JOURNAL OF RESEARCH-The Journal of Research of the National Bureau of Standards reports NBS research and develop. ment in thuse disciplines of the physical and enpineering sciences in which the Bureau is active. These include physics, chenistry, enginecring, mathemalics, and computer sciences Papers cover a broud range of subjects. with major emphasis on measurement methodology and the basic lechnology underlying standardizallion Also included from time to lime are surves articles on lupies closely related to the Burcau's technical and scientific programs. As a special service to subscribers each issue contains complete cilations to all recent Bureau publicalions in both NBS and non. NBS media. Issued six times a year. Annual subscription doniestic S18: forcign \$22.50. Single cony. \$4.25 domestic: 5.35 foreign.

\section{NONPERIODICALS}

Monographs-Major contribulions (t) the lechnical literature un various subjects related to the Bureau, scientific and ischnicial activities.

Handbooks-Recommended cocies of enginecring and indusirial practice (including safely codes) developed in so.speration wilh in. terested industries. professional organizallions. and regulalory bodies.

Erecial Publleations-Include proceedings of cunferences sponsored by NBS. NBS annual reports, and other speccial publications uppropriate to this grouping such as wall charts. packet cards, and bibliographies.

Applied Mathematics Serles-Mathemalical tubles, manuals, and studies of special interesi 10 physicists, engineers. chemists. biologists. mathematicians, computer programmers, and others enguged in scientific and lechnical work

Natlonal Standard Reference Data Series-Provides yuantilative data on the physical and chemical properties of materials. compiled from the world's literilture and eritically evalualted. Developed under a worldwide proyram coordinaled by NBS under the authority of the National Standard Dala Act (Public Law 90.3961.

NOTE: The principal publicution outlet for the foregoing data is the Journal of Physical and (hemical Reference Data (JPCRD) published quarterly for NBS by the American Chemical Society (ACS) and the American Institute of Physics (A|P). Subscriptions. reprints, and supplements available from ACS. IIss Sixleenth St. NW, Washington. DC 20056

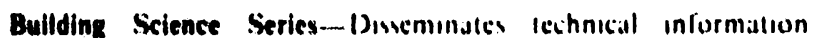
develofed at the Burealu on building mollerials. components. systems, and whole seructures The series presents research resulls. lest metheds. and performance criteria relatled (o) ihe veruclural and entironniental funcluses and the durinility and silfely chatracleristics of huilding elements and systems

Technical Nores-Sludies or reports which are complele in them. selves hut restrictive in their irealtment of a subject. Analogeus (t) monographs hul nol w comprehensive in scone ar definilive in Irealment of the subjecl are:i. Oflen seeve an a vehicle for final reports of work performed it NBS under the sponsorship of wher government agencies

Voluntary Product Standards-Developed under procedures published hy the Departinent of Commerce in Part 10. Tille is, of the Code of Federal Regulations. The standurds estatslish natlionally recogniced requirements for producis. and providt all concerned interests with a hasis for common understanding wi the char aclerislics of the products NBS aldminislers this program is a supplement to the activilles of the privale sector standardieing orgunizaltions.

Consumer Information Series-Practical information, based on NBS research and experience. covering areas of interest to the conl). sumer. Easily undersiandable language and illusirations provide useful background knowledge for shopping in loday's lechnolugical marketplace.

Order the above NBS puthlications Jrom: Sicierintendent of Docw. ments. Government Primling Office. Washinglon. DC 2(140)2.

Order the following NBS publicaliusm:- FIPS and NBSIR:S-Jrom the National Terhnical Infiurmation sienvices. Sipring/ield. VA islol

Federal Information Processing Standards Publlcations IFIPS PUB)-Publications in this series collectively constitute the Federal Information Processing Standards Register. The Register serves as the official source of information in the Federal Govern. ment regarding standards issued by NBS pursuant to the foderal Property and Administrative Strvices Act of 1949 as amended. Public Lalw 89.306 (79 Stal. 1127), and us implemented hy tix. eculive Order 11717 (38 FR 12315. duted Muy 11. 1973) and Purl 6 of Tille 15 CrR (Cinde of Federal Regulations).

NBS Interagency Reports (NBSIR) - A speciul series of intcrim or final reports on work performed by NBS for outside sponsors (both government and non-government). In general, initial disIribution is handled by the sponsor: public distribution is by the Niltional Technical Information Services. Springficld. VA 22161, in paper copy or microfiche form. 